\title{
Prismarenes: A New Class of Macrocyclic Hosts Obtained by Templation in a Thermodynamically Controlled Synthesis
}

Paolo Della Sala, ${ }^{[a]}$ Rocco Del Regno, ${ }^{[a]}$ Carmen Talotta, ${ }^{[a]}$ Amedeo Capobianco, ${ }^{[a]}$ Neal Hickey, ${ }^{[b]}$ Silvano Geremia, ${ }^{[b]}$ Margherita De Rosa, ${ }^{[a]}$ Aldo Spinella, ${ }^{[a]}$ Annunziata Soriente, ${ }^{\left[{ }^{[a]}\right.}$ Placido Neri, ${ }^{[a]}$ and Carmine Gaeta*,[a]

†Laboratory of Supramolecular Chemistry, Dipartimento di Chimica e Biologia, "A. Zambelli”, Università di Salerno, Via Giovanni Paolo II 132, Fisciano (SA), I-84084, Italy. ${ }^{\ddagger}$ Centro di Eccellenza in Biocristallografia, Dipartimento di Scienze Chimiche e Farmaceutiche, Università di Trieste, Via L. Giorgieri 1, I-34127 Trieste, Italy.

Table of Contents

Pages

General Experimental Details S2

General procedure for the synthesis of the Prism[n]arenes S2

Copies of NMR and HR Mass Spectra of Prism[n]arenes S5

Copies of NMR and HR Mass Spectra of Prismarene Complexes S24

${ }^{1} \mathrm{H}$ NMR determination of $\mathrm{K}_{\mathrm{ass}}$ values $\quad$ S58

HPLC analysis of the cyclocondensation kinetics

S74

Determination of the crystallographic structures of Prism[5]arene (1) and 1,4-

S75 confused-Prism[5]arene (2)

Equilibrium geometries and electronic energies S82 


\section{General Experimental Details}

HR MALDI mass spectra were recorded on a Bruker Solarix FT-ICR mass spectrometer equipped with a 7T magnet. The samples recorded in MALDI were prepared by mixing $10 \mu \mathrm{L}$ of analyte in dichloromethane $(1 \mathrm{mg} / \mathrm{mL})$ with $10 \mu \mathrm{L}$ of solution of 2,5 -dihydroxybenzoic acid $(10 \mathrm{mg} / \mathrm{mL}$ in Metanol). The mass spectra were calibrated externally, and a linear calibration was applied. All reaction solvents were dried by activated $3 \AA$ molecular sieves ${ }^{1}$. All chemicals reagents grade was used without further purification and were used as purchased. Reaction temperatures were measured externally. Reactions were monitored by TLC silica gel plates $(0.25 \mathrm{~mm})$ and visualized by UV light $254 \mathrm{~nm}$, or by spraying with $\mathrm{H}_{2} \mathrm{SO}_{4}-\mathrm{Ce}\left(\mathrm{SO}_{4}\right)_{2}$. NMR spectra were recorded on a Bruker Avance-600 $\left[600\left({ }^{1} \mathrm{H}\right)\right.$ and $\left.150 \mathrm{MHz}\left({ }^{13} \mathrm{C}\right)\right]$, Avance-400 [400 $\left({ }^{1} \mathrm{H}\right)$ and $\left.100 \mathrm{MHz}\left({ }^{13} \mathrm{C}\right)\right]$ or Avance-300 MHz [300 $\left({ }^{1} \mathrm{H}\right)$ and $\left.75 \mathrm{MHz}\left({ }^{13} \mathrm{C}\right)\right]$ spectrometers. Chemical shifts are reported relative to the residual solvent peak $^{2}$. Standard pulse programs, provided by the manufacturer, were used for 2D COSY-45, 2D HSQC, 2D HMBC and 2D NOESY experiments.

\section{General procedure for the synthesis of Prism[n]arenes.}

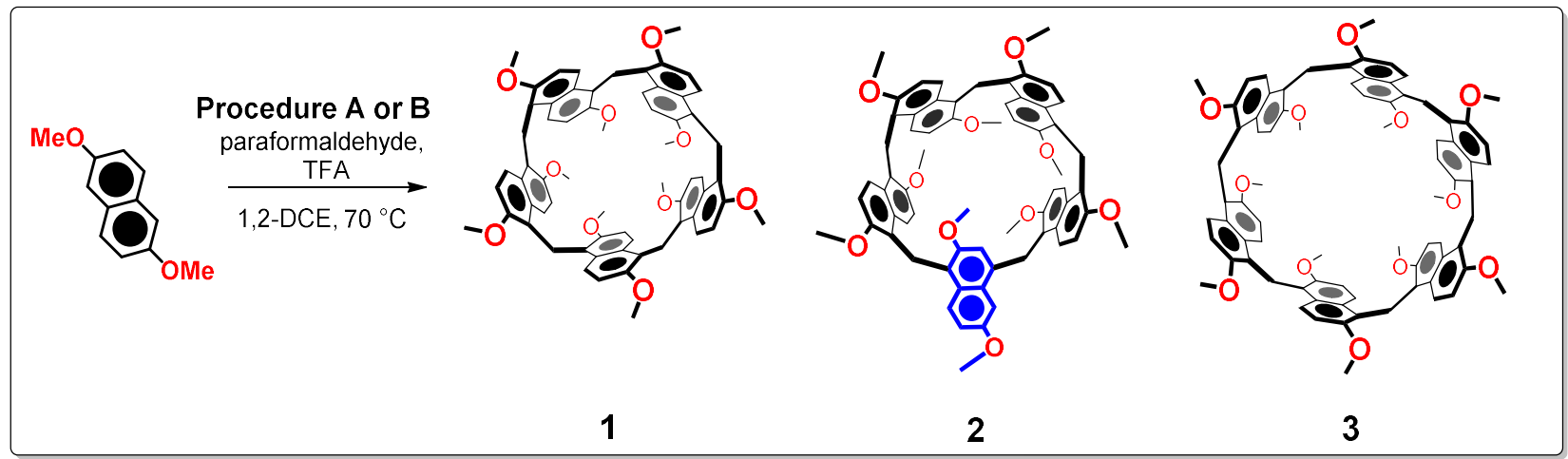

Procedure A. A solution of 2,6-dimethoxynaphthalene (250 mg, $1.33 \mathrm{mmol})$, paraformaldehyde (48 $\mathrm{mg}, 1.60 \mathrm{mmol}, 1.2$ equiv) in $530 \mathrm{~mL}$ of dry 1,2-dichloroethane was heated to $70^{\circ} \mathrm{C}$, then trifluoroacetic acid ( $1.5 \mathrm{~mL}, 0.02 \mathrm{~mol}, 15$ equiv) was added. The solution was stirred for $22 \mathrm{~h}$ at $70^{\circ} \mathrm{C}$ and subsequently the solvent evaporated under reduced pressure. The residue was dissolved in $\mathrm{CH}_{2} \mathrm{Cl}_{2}(30 \mathrm{~mL})$ and the mixture was washed with an aqueous saturated solution of $\mathrm{NaHCO}_{3}(30 \mathrm{~mL})$. Finally, the organic layer was washed with brine $(2 \times 20 \mathrm{~mL})$, and the organic phases were dried over sodium sulfate and concentrated to give a solid light brown. The crude product was purified by chromatographic column on silica gel (hexane/dichloromethane $=1 / 9$ ). Macrocycle 1 was obtained in $0.3 \%$ of yield ( $1 \mathrm{mg}$ ) and macrocycle 2 was obtained as a white solid (106 $\mathrm{mg}, 40 \%)$.

Procedure B. A solution of 2,6-dimethoxynaphthalene (250 mg, $1.33 \mathrm{mmol}$ ), paraformaldehyde (48 $\mathrm{mg}, 1.60 \mathrm{mmol}, 1.2$ equiv), and templating agent, $\mathbf{4}^{\mathbf{2 +}} \cdot \mathbf{2 \mathbf { I } ^ { - }}, \mathbf{5}^{+} \cdot \mathbf{I}^{-}$or $\mathbf{6}^{+} \cdot \mathbf{I}^{-}(1.33 \mathrm{mmol}, 1.0$ equiv) in $530 \mathrm{~mL}$ of dry 1,2 -dichloroetane was heated to $70^{\circ} \mathrm{C}$, then trifluoroacetic acid $(1.5 \mathrm{~mL}, 0.02 \mathrm{~mol}, 15$ equiv) was added. The solution was stirred for $22 \mathrm{~h}$ (in presence of $\mathbf{4}^{\mathbf{2 +} \cdot \mathbf{2 I}^{-}}$and $\mathbf{5}^{+} \cdot \mathbf{I}^{-}$) or $72 \mathrm{~h}$ (in presence of $\mathbf{6}^{+} \cdot \mathbf{I}^{-}$) at $70^{\circ} \mathrm{C}$ and subsequently the solvent evaporated under reduced pressure. The residue was dissolved in $\mathrm{CH}_{2} \mathrm{Cl}_{2}(30 \mathrm{~mL})$ and the mixture was washed with an aqueous saturated solution of $\mathrm{NaHCO}_{3}(30 \mathrm{~mL})$. Finally, the organic layer was washed with brine $(2 \times 20 \mathrm{~mL})$, and the organic phases were dried over sodium sulfate and concentrated to give a solid light brown. The crude product was purified by chromatographic column on silica gel (hexane/dichloromethane $=1 / 9$ ). 
Template synthesis in presence of $\mathbf{4}^{\mathbf{2 +}} \cdot \mathbf{2} \mathbf{I}^{-}$salt: The macrocycle $\mathbf{1}$ was obtained in $47 \%$ yield (125 $\mathrm{mg}$ ) and the macrocycle 2 in $16 \%$ yield (42 mg).

Template synthesis in presence of $5^{+} \cdot \mathbf{I}^{-}$salt: The macrocycle 1 was obtained in $32 \%$ of yield ( 85 $\mathrm{mg}$ ) and the macrocycle 2 in $8 \%$ of yield $(21 \mathrm{mg})$.

Template synthesis in presence of $\mathbf{6}^{+} \cdot \mathbf{I}^{-}$salt: The macrocycle 1 was obtained in $0.3 \%$ yield $(1 \mathrm{mg})$, the macrocycle 2 in $6 \%$ yield $(16 \mathrm{mg}$ ) and the macrocycle 3 was obtained in $20 \%$ yield (54 mg).

\section{Derivative 1:}

Mp: $>374{ }^{\circ} \mathrm{C}$ dec.

${ }^{1} \mathbf{H}$ NMR $\left(\mathrm{CD}_{2} \mathrm{Cl}_{2}, 600 \mathrm{MHz}, 298 \mathrm{~K}\right): \delta 7.95(d, 10 \mathrm{H}, \mathrm{Ar}-H, J=9.4 \mathrm{~Hz}), 6.92(d, 10 \mathrm{H}, \mathrm{Ar}-H, J=9.4$ $\mathrm{Hz}), 4.68\left(s, 10 \mathrm{H}, \mathrm{ArCH} \mathrm{H}_{2} \mathrm{Ar}\right), 3.63(s, 30 \mathrm{H}, \mathrm{OMe})$.

${ }^{13} \mathrm{C}$ NMR $\left(\mathrm{CD}_{2} \mathrm{Cl}_{2}, 150 \mathrm{MHz}, 298 \mathrm{~K}\right): \delta 153.1,129.8,125.0,123.7,113.9,56.8,21.8$.

DEPT-135 $\left(\mathrm{CD}_{2} \mathrm{Cl}_{2}, 150 \mathrm{MHz}, 298 \mathrm{~K}\right): \delta 125.0,113.9,56.8,21.8$.

HRMS (MALDI) $\mathrm{m} / \mathrm{z}[\mathrm{M}]^{+}$calcd for $\mathrm{C}_{65} \mathrm{H}_{60} \mathrm{O}_{10}$ : 1000.4186. found: 1000.4227 .

\section{Derivative 2:}

Mp: $>385^{\circ} \mathrm{C}$ dec.

${ }^{1} \mathbf{H}$ NMR $\left(\mathrm{CD}_{2} \mathrm{Cl}_{2}, 600 \mathrm{MHz}, 298 \mathrm{~K}\right): \delta 8.37-8.35$ (overlapped, $\left.2 \mathrm{H}, \mathrm{Ar}-H\right), 8.19(\mathrm{~d}, 1 \mathrm{H}, \mathrm{Ar}-H, J=$ $9.4 \mathrm{~Hz}), 7.63(\mathrm{~d}, 1 \mathrm{H}, \mathrm{Ar}-H, J=9.3 \mathrm{~Hz}), 7.58(\mathrm{~d}, 1 \mathrm{H}, \operatorname{Ar}-H, J=9.4 \mathrm{~Hz}), 7.53(\mathrm{~d}, 1 \mathrm{H}, \operatorname{Ar}-H, J=2.6$ $\mathrm{Hz}), 7.46(\mathrm{~d}, 1 \mathrm{H}, \mathrm{Ar}-H, J=9.4 \mathrm{~Hz}), 7.43(\mathrm{~d}, 1 \mathrm{H}, \mathrm{Ar}-H, J=9.4 \mathrm{~Hz}), 7.34$ (d, $1 \mathrm{H}, \mathrm{Ar}-H, J=9.4 \mathrm{~Hz})$, 7.30-7.27 (overlapped, 2H, Ar-H), $7.26(\mathrm{~s}, 1 \mathrm{H}, \operatorname{Ar}-H), 7.18(\mathrm{~d}, 1 \mathrm{H}, \operatorname{Ar}-H, J=9.4 \mathrm{~Hz}), 7.12(\mathrm{~d}, 1 \mathrm{H}$, $\operatorname{Ar}-H, J=9.4 \mathrm{~Hz}), 6.97$ (d, $1 \mathrm{H}, \mathrm{Ar}-H, J=9.4 \mathrm{~Hz}), 6.82$ (d, $1 \mathrm{H}, \mathrm{Ar}-H, J=9.4 \mathrm{~Hz}), 6.78$ (d, $1 \mathrm{H}, \mathrm{Ar}-H$, $J=9.4 \mathrm{~Hz}$ ), 6.45 (d, 1H, Ar- $H, J=9.4 \mathrm{~Hz}), 6.29$ (d, $1 \mathrm{H}, \mathrm{Ar}-H, J=9.4 \mathrm{~Hz}$ ), 4.98-4.83 (overlapped, $6 \mathrm{H}, \mathrm{ArCH} \mathrm{H}_{2} \mathrm{Ar}$ and $\mathrm{Ar}-\mathrm{H}$ ), 4.70-4.64 (overlapped, $2 \mathrm{H}, \mathrm{ArCH} \mathrm{Ar}_{2} \mathrm{Ar}$ ), 4.51-4.36 (overlapped, 3H, $\left.\mathrm{ArCH} \mathrm{H}_{2} \mathrm{Ar}\right), 4.21$ (s, 3H, OMe), 4.20 (s, 3H, OMe), 4.04 (s, 3H, OMe), 4.01 (s, 3H, OMe), 4.00(s, 3H, $\mathrm{OMe}$ ), 3.69 (s, 3H, OMe), 3.67 (s, 3H, OMe), 2.84 (s, 3H, OMe), 2.17 (s, 3H, OMe), -0.03 (s, 3H, $\mathrm{OMe}$.

${ }^{13} \mathrm{C}$ NMR $\left(\mathrm{CD}_{2} \mathrm{Cl}_{2}, 150 \mathrm{MHz}, 213 \mathrm{~K}\right): \delta 155.6,153.1,152.7,152.0,151.6,151.5,151.4,151.1,150.9$, $150.5,134.4,129.2,128.8,128.7,128.6,128.2,128.0,127.9,127.5,125.1,124.9,124.7,124.3,124.0$, $123.9,123.7,123.6,123.4,123.0,122.8,122.4,120.9,119.8,117.9,117.2,116.9,115.4,112.5,112.2$, $111.7,111.6,110.9,110.7,102.1,56.7,56.5,56.2,56.1,56.0,55.8,55.6,55.2,54.7,53.3,26.6,23.4$, 21.6, 20.3, 20.1.

HRMS (MALDI) m/z [M] calcd for $\mathrm{C}_{65} \mathrm{H}_{60} \mathrm{O}_{10}$ : 1000.4186. found: 1000.4218.

\section{Derivative 3:}

Mp: $>352{ }^{\circ} \mathrm{C}$ dec.

${ }^{1}$ H NMR (TCDE, $\left.300 \mathrm{MHz}, 393 \mathrm{~K}\right): \delta 7.64(d, 12 \mathrm{H}, \mathrm{Ar}-H, J=9.3 \mathrm{~Hz}), 6.72(d, 12 \mathrm{H}, \mathrm{Ar}-H, J=9.3$ $\mathrm{Hz}), 4.61\left(s, 12 \mathrm{H}, \mathrm{ArCH} \mathrm{H}_{2} \mathrm{Ar}\right), 3.27(s, 36 \mathrm{H}, \mathrm{OMe})$.

${ }^{13}$ C NMR (TCDE, $75 \mathrm{MHz}, 298 \mathrm{~K}$ ): $\delta$ 152.1, 129.2, 123.9, 123.7, 114.1, 56.5, 29.6.

HRMS (MALDI) m/z [M] ${ }^{+}$calcd for $\mathrm{C}_{78} \mathrm{H}_{72} \mathrm{O}_{12}: 1200.5024$. found: 1200.5117 . 
Table S1: Procedure A. Yields of $\mathbf{1}$ and $\mathbf{2}$ in the presence different solvents.

\begin{tabular}{ccc}
\hline Solvent & Yield of $\mathbf{1}$ & Yield of $\mathbf{2}$ \\
\cline { 2 - 3 } o-dichlorobenzene & ---- & $9.4 \%$ \\
Chloroform & --- & $9.6 \%$ \\
1,1,2, -trichloroethane & ---- & --- \\
1,1,2,2-tetrachloroethane & --- & $18 \%$ \\
\hline
\end{tabular}




\section{Copies of NMR and HR Mass Spectra of Prism[n]arenes}

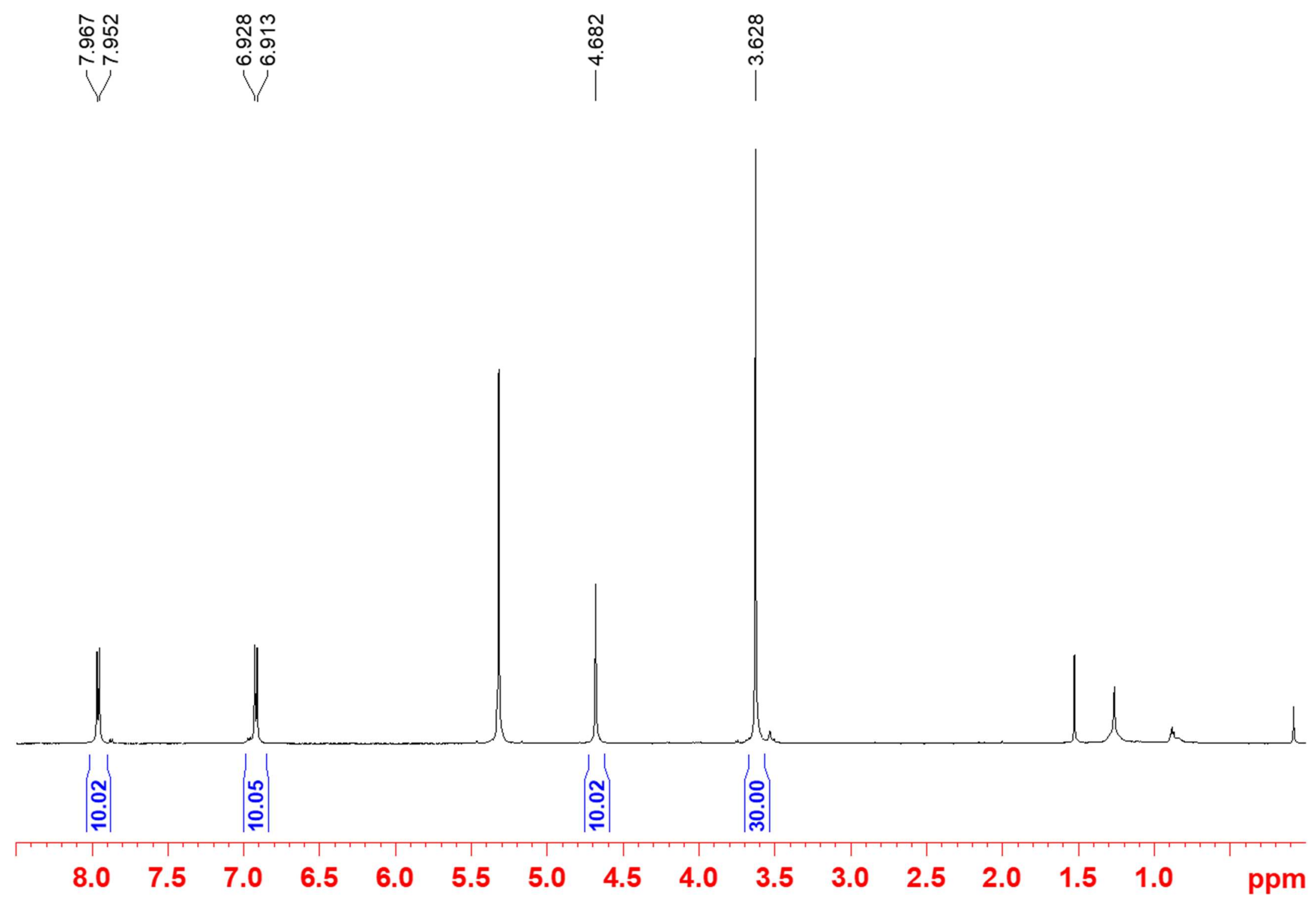

Figure S1: ${ }^{1} \mathrm{H}$ NMR spectrum of $1\left(\mathrm{CD}_{2} \mathrm{Cl}_{2}, 600 \mathrm{MHz}, 298 \mathrm{~K}\right)$. 


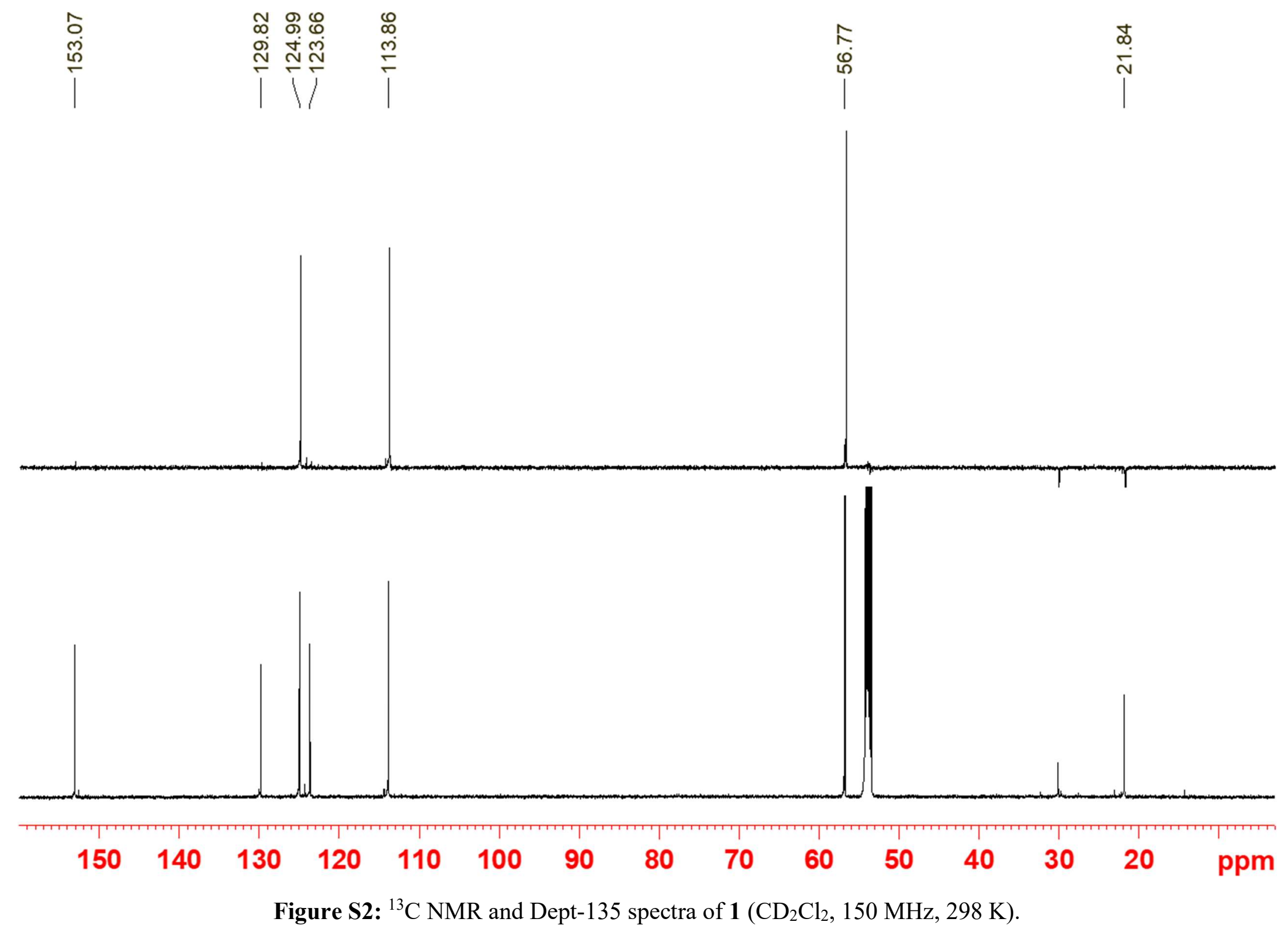




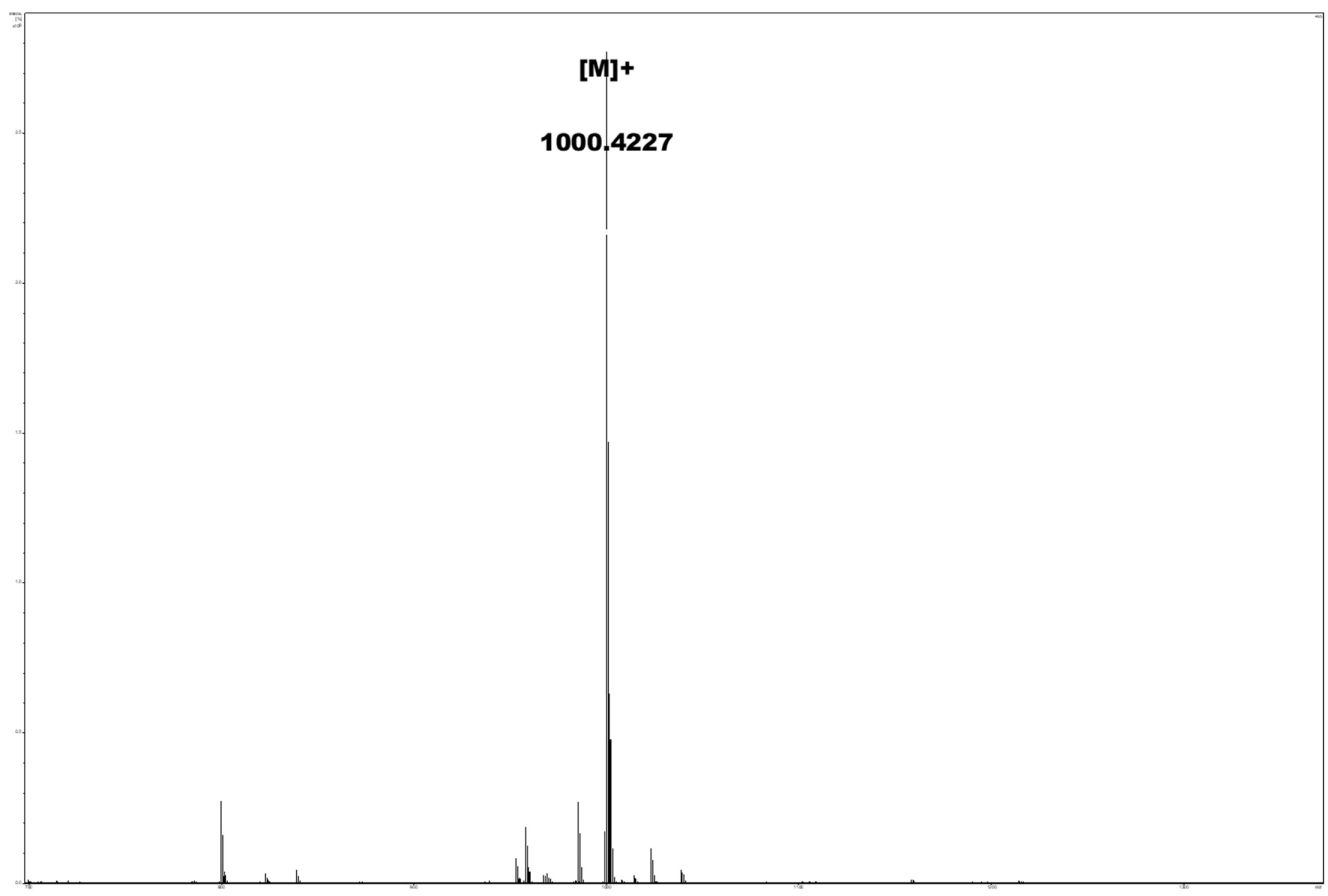

Figure S3: Significant portion of the HR MALDI FT-ICR mass spectrum of $\mathbf{1}[\mathrm{M}]^{+}$. 


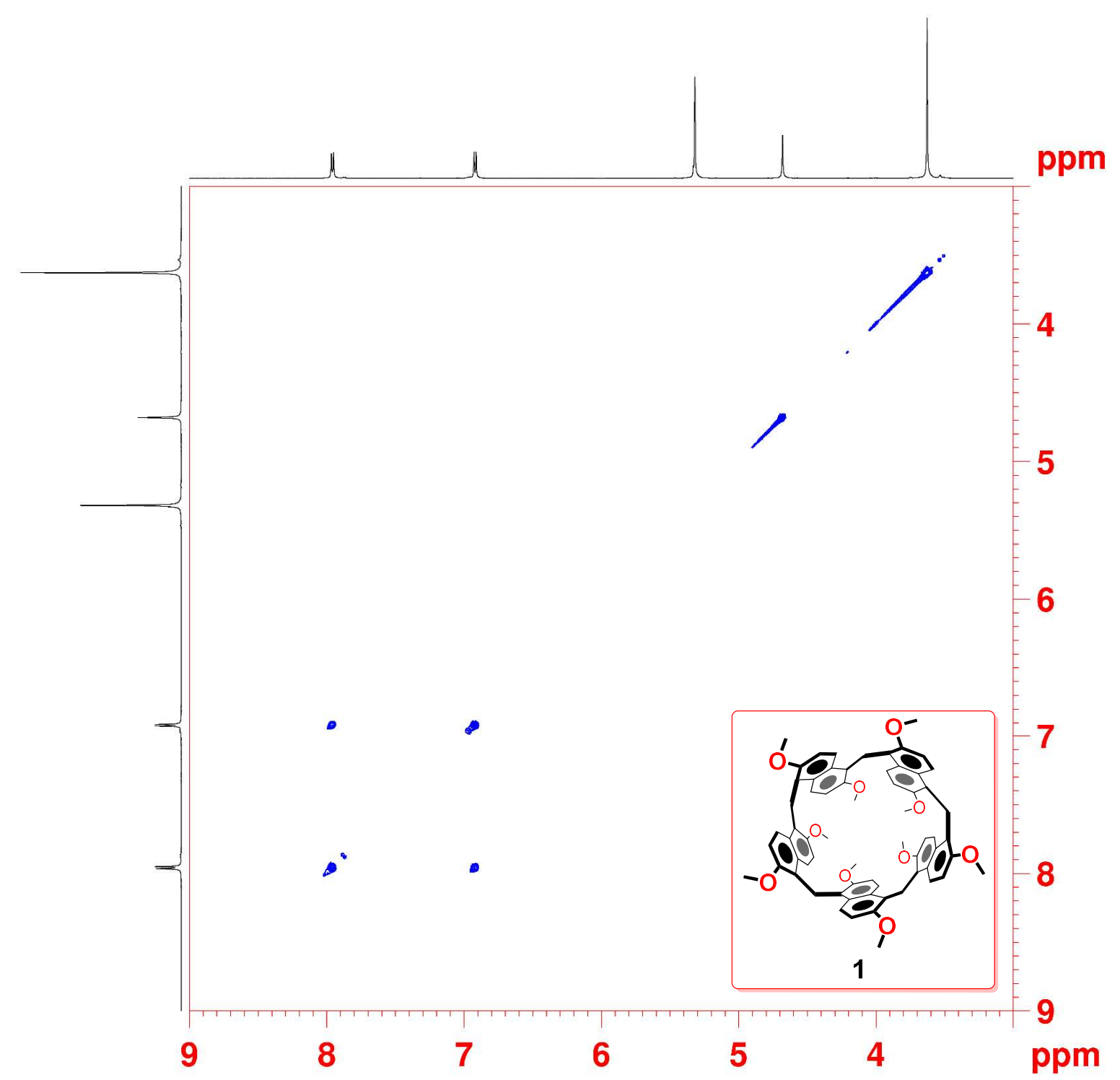

Figure S4: 2D-DQF COSY spectrum of $\mathbf{1}\left(\mathrm{CD}_{2} \mathrm{Cl}_{2}, 600 \mathrm{MHz}, 298 \mathrm{~K}\right)$. 


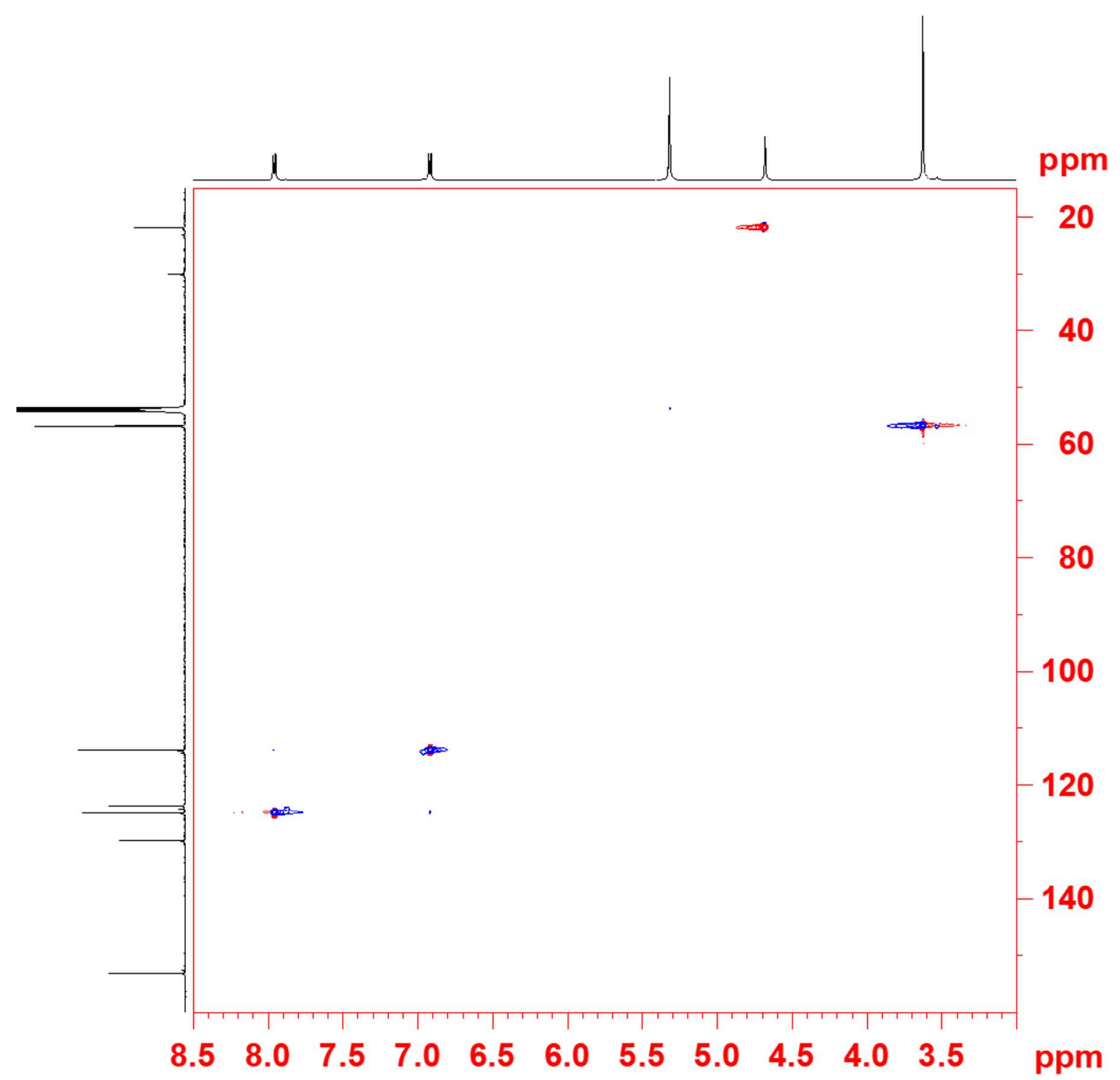

Figure S5: 2D-HSQC spectrum of $1\left(\mathrm{CD}_{2} \mathrm{Cl}_{2}, 600 \mathrm{MHz}, 298 \mathrm{~K}\right)$. 
${ }^{1} \mathrm{H}$ NMR, ${ }^{13} \mathrm{C}$ NMR and HR mass spectrum of derivatives 2

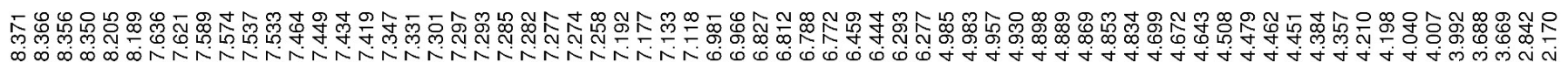
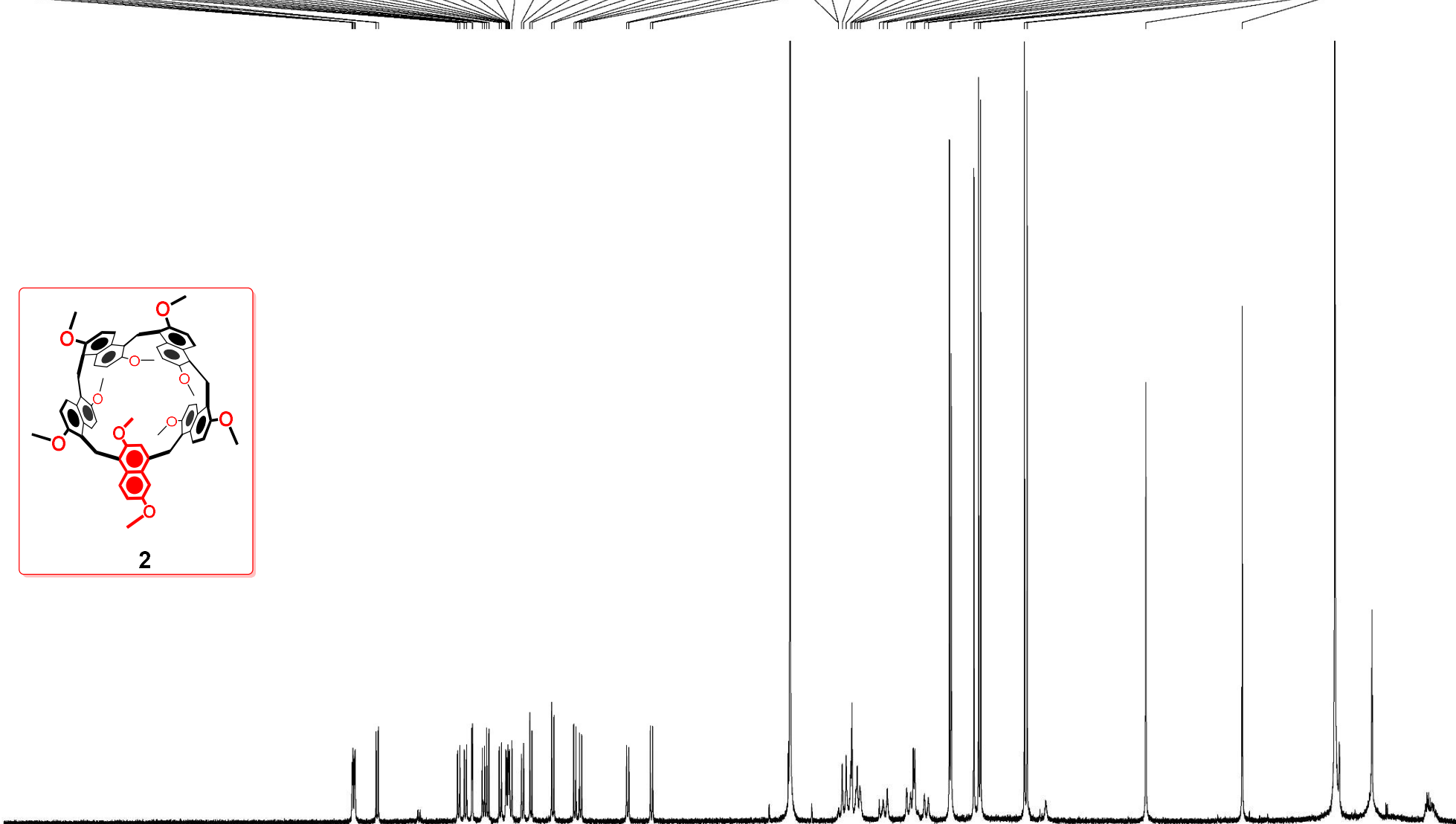

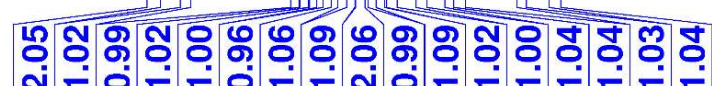

\% : -

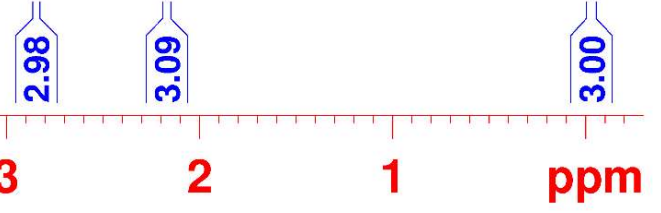

Figure S6: ${ }^{1} \mathrm{H}$ NMR spectrum of $2\left(\mathrm{CD}_{2} \mathrm{Cl}_{2}, 600 \mathrm{MHz}, 298 \mathrm{~K}\right)$. 


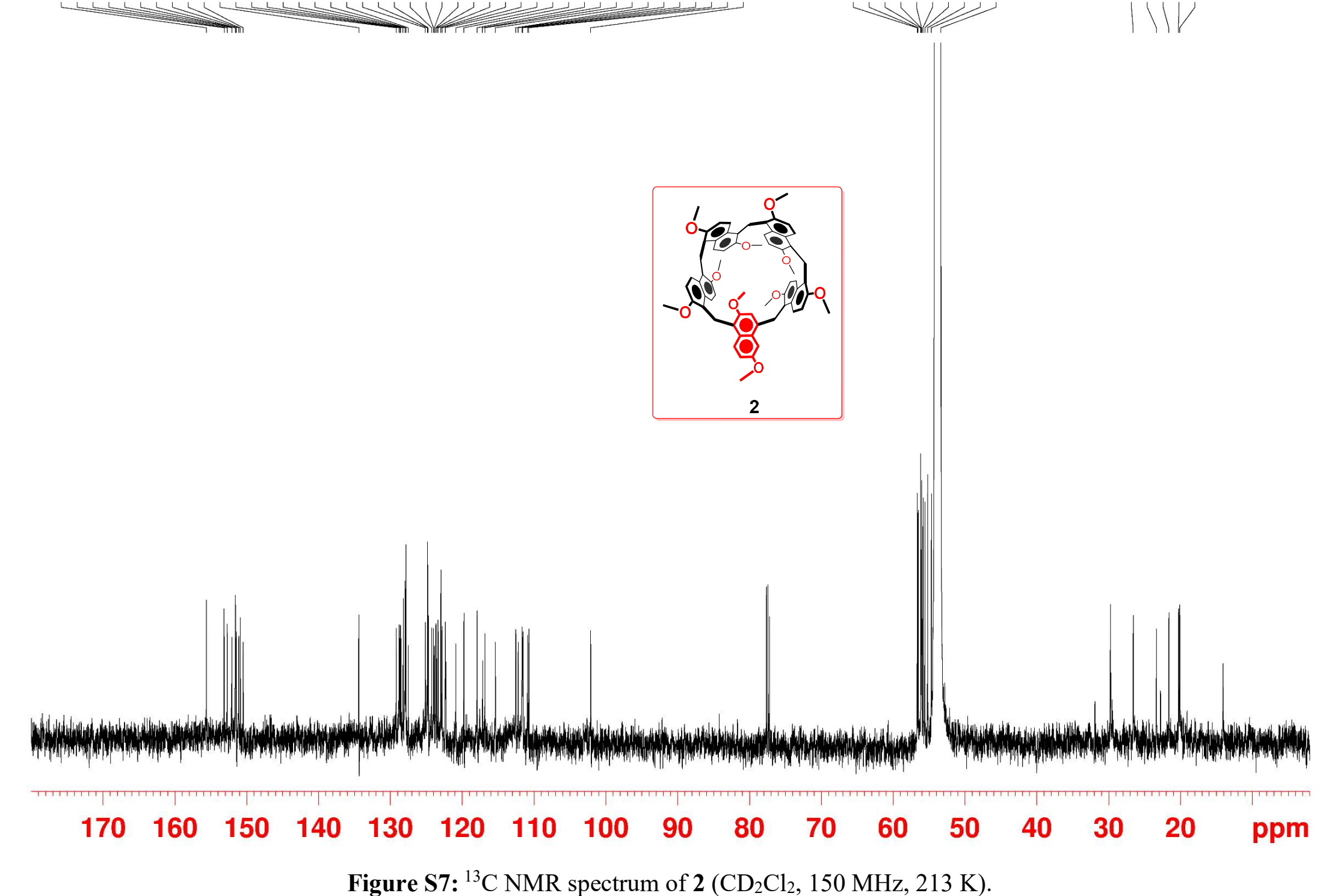




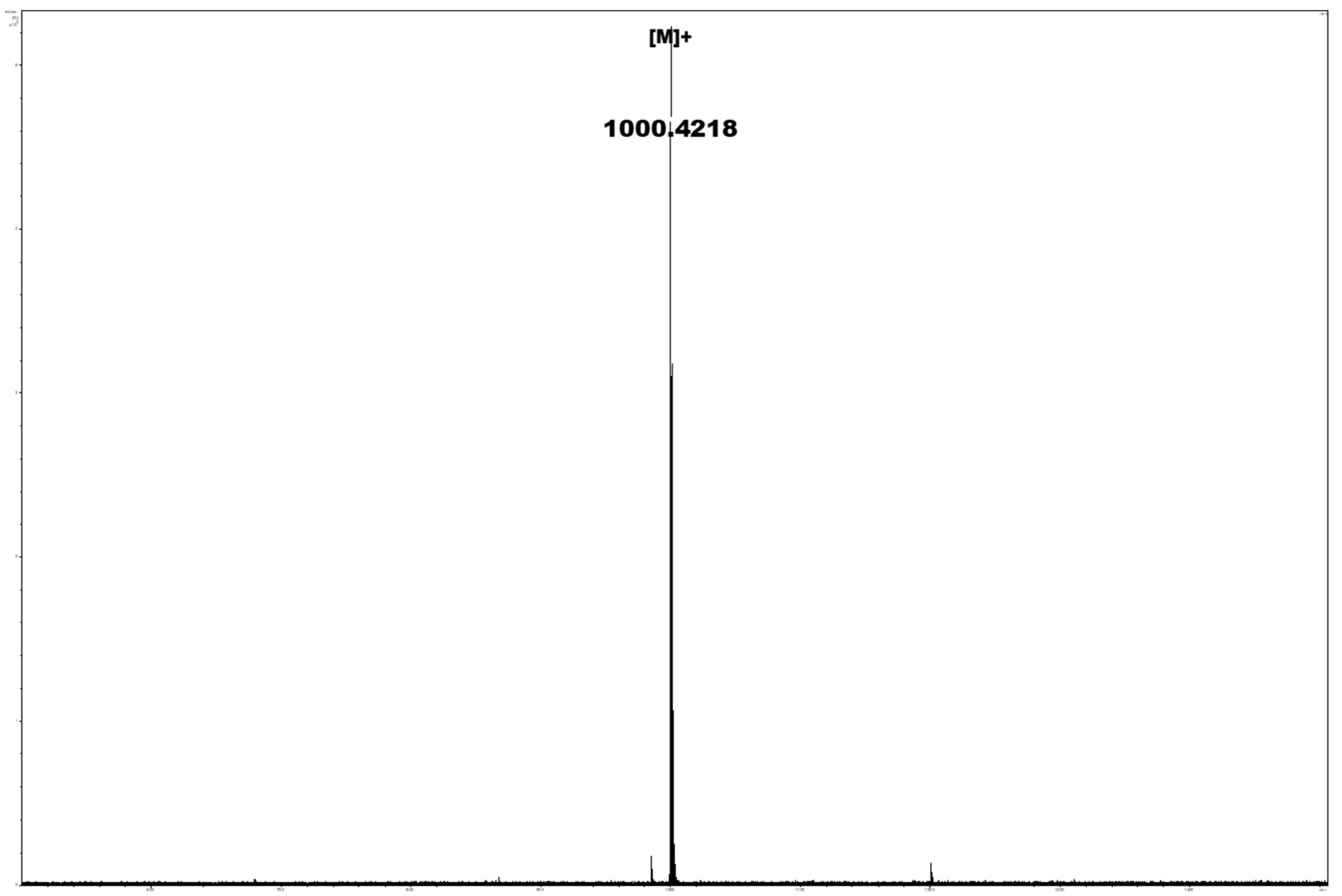

Figure S8: Significant portion of the HR MALDI FT-ICR mass spectrum of $2[\mathrm{M}]^{+}$. 


\section{${ }^{1}$ H VT NMR of 2}

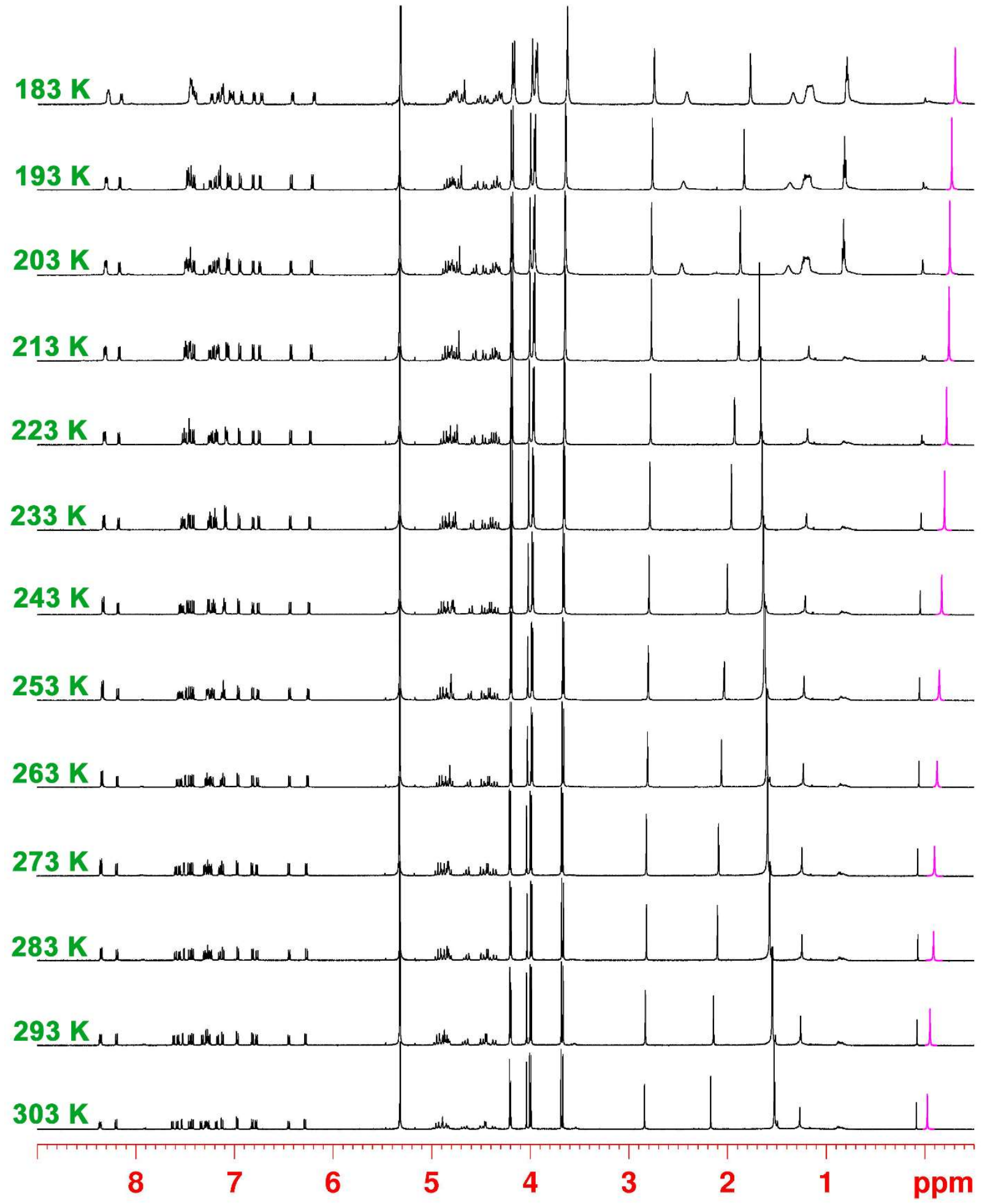

Figure S9: ${ }^{1} \mathrm{H}$ NMR spectrum of $2\left(600 \mathrm{MHz}, \mathrm{CD}_{2} \mathrm{Cl}_{2}\right)$ at (from bottom to top): 303, 293, 273, 263, $253,243,233,223,213,203,193$, and $183 \mathrm{~K}$. 


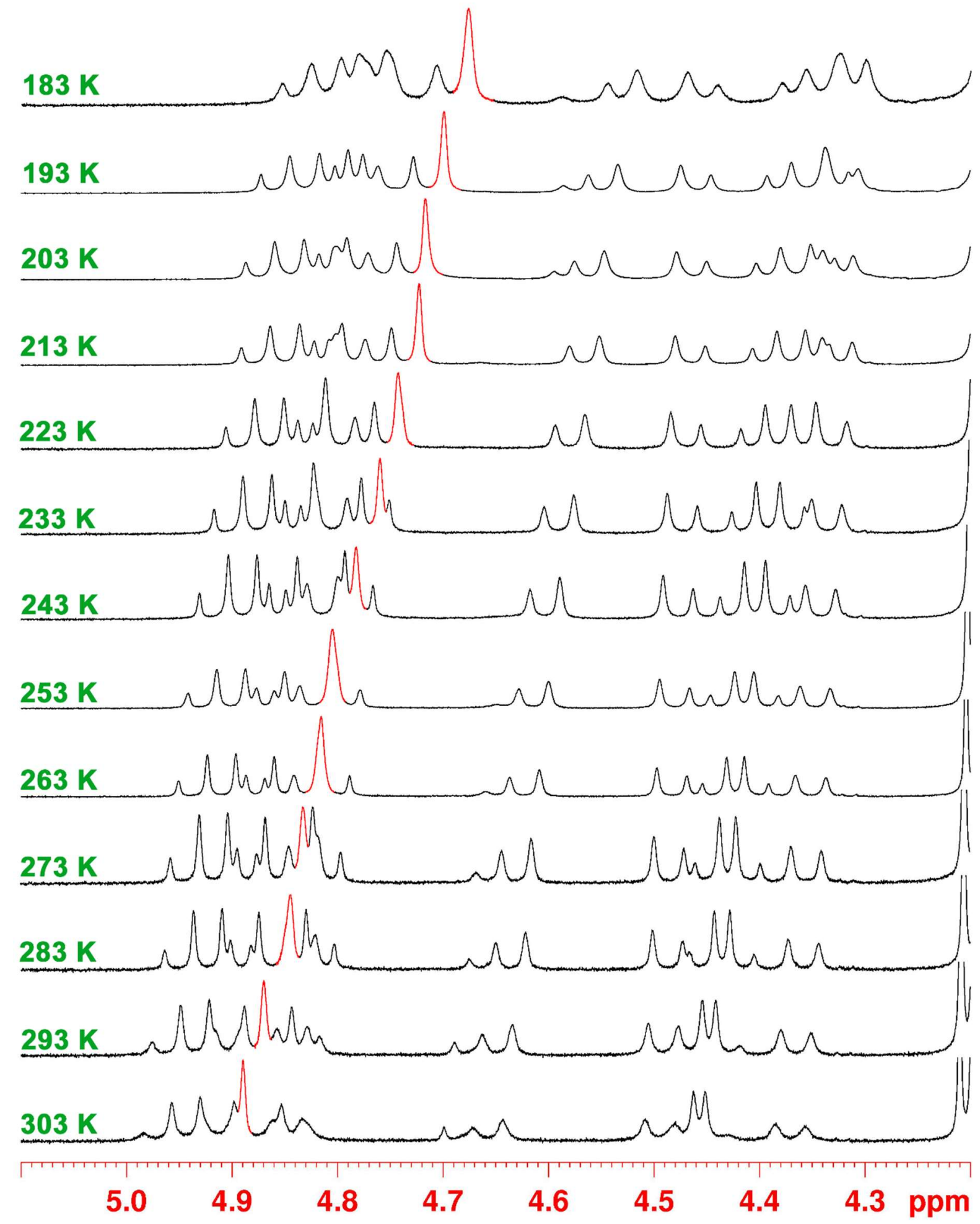

Figure S10: Relevant region of the ${ }^{1} \mathrm{H}$ NMR spectrum of $2\left(600 \mathrm{MHz}, \mathrm{CD}_{2} \mathrm{Cl}_{2}\right)$ at (from bottom to top): $303,293,273,263,253,243,233,223,213,203,193$, and $183 \mathrm{~K}$. 


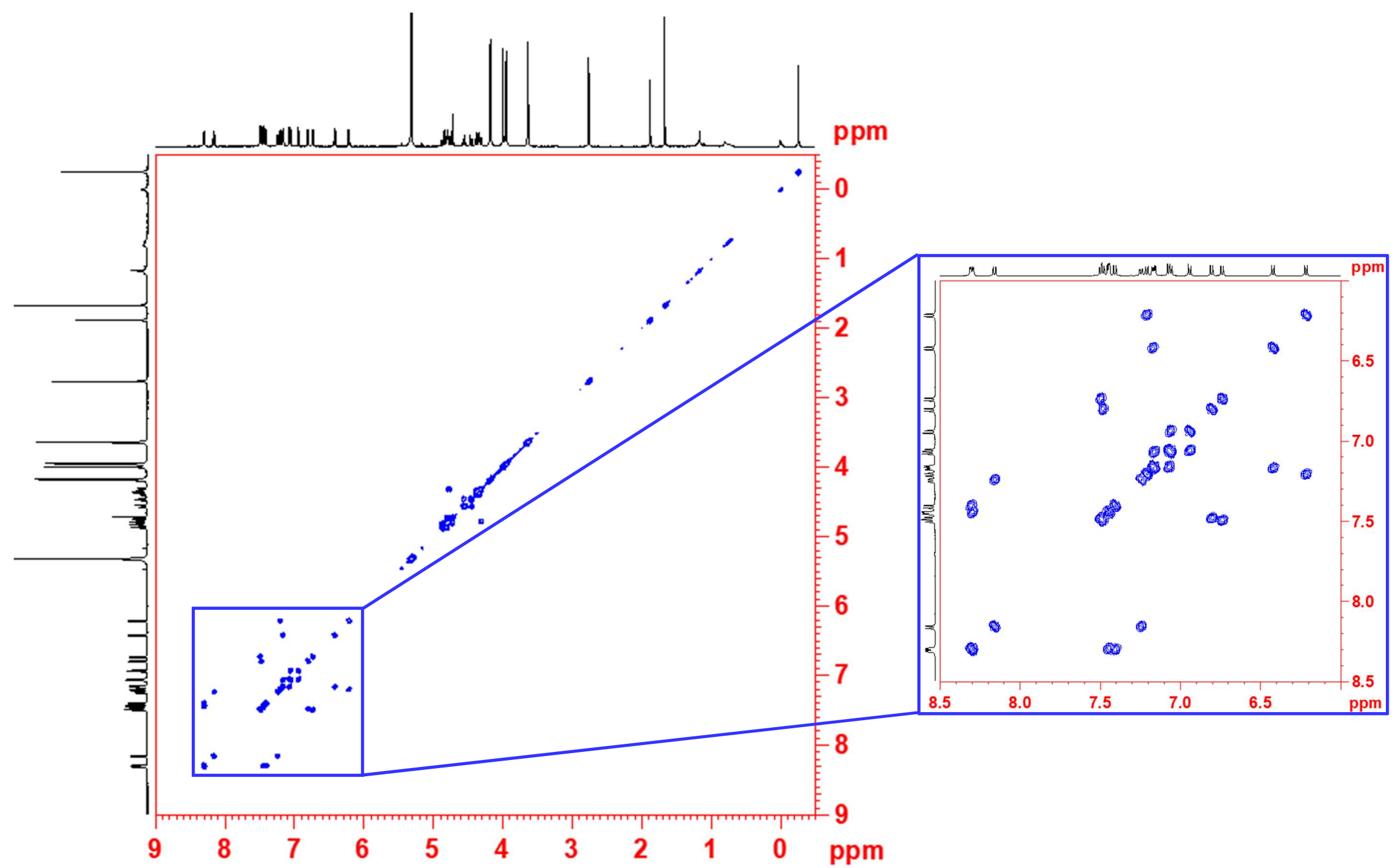

Figure S11: 2D-DQF COSY spectrum of $2\left(\mathrm{CD}_{2} \mathrm{Cl}_{2}, 600 \mathrm{MHz}, 213 \mathrm{~K}\right)$. 


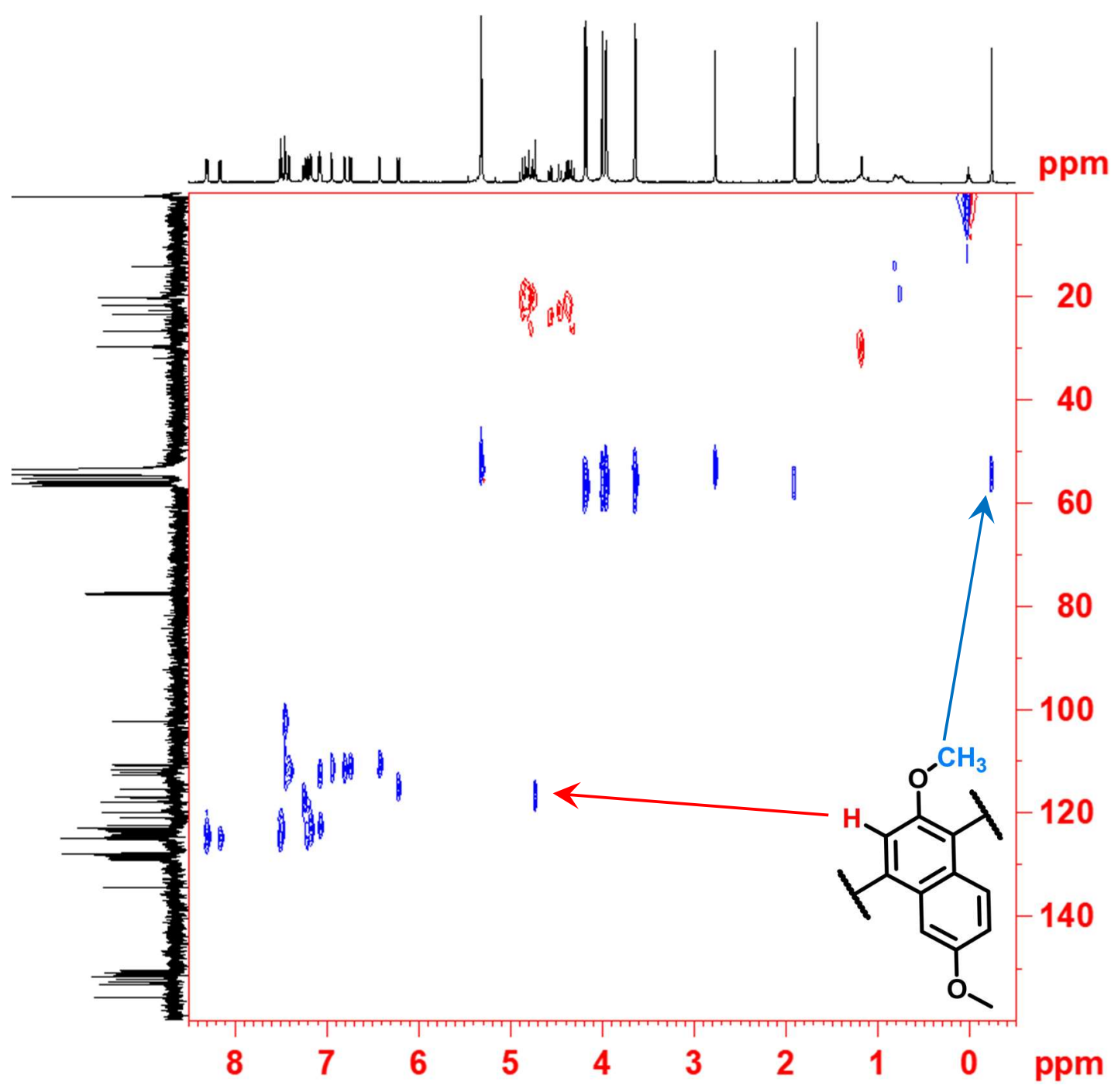

Figure S12: Significant portion of 2D-HSQC spectrum of $2\left(\mathrm{CD}_{2} \mathrm{Cl}_{2}, 600 \mathrm{MHz}, 213 \mathrm{~K}\right)$. 

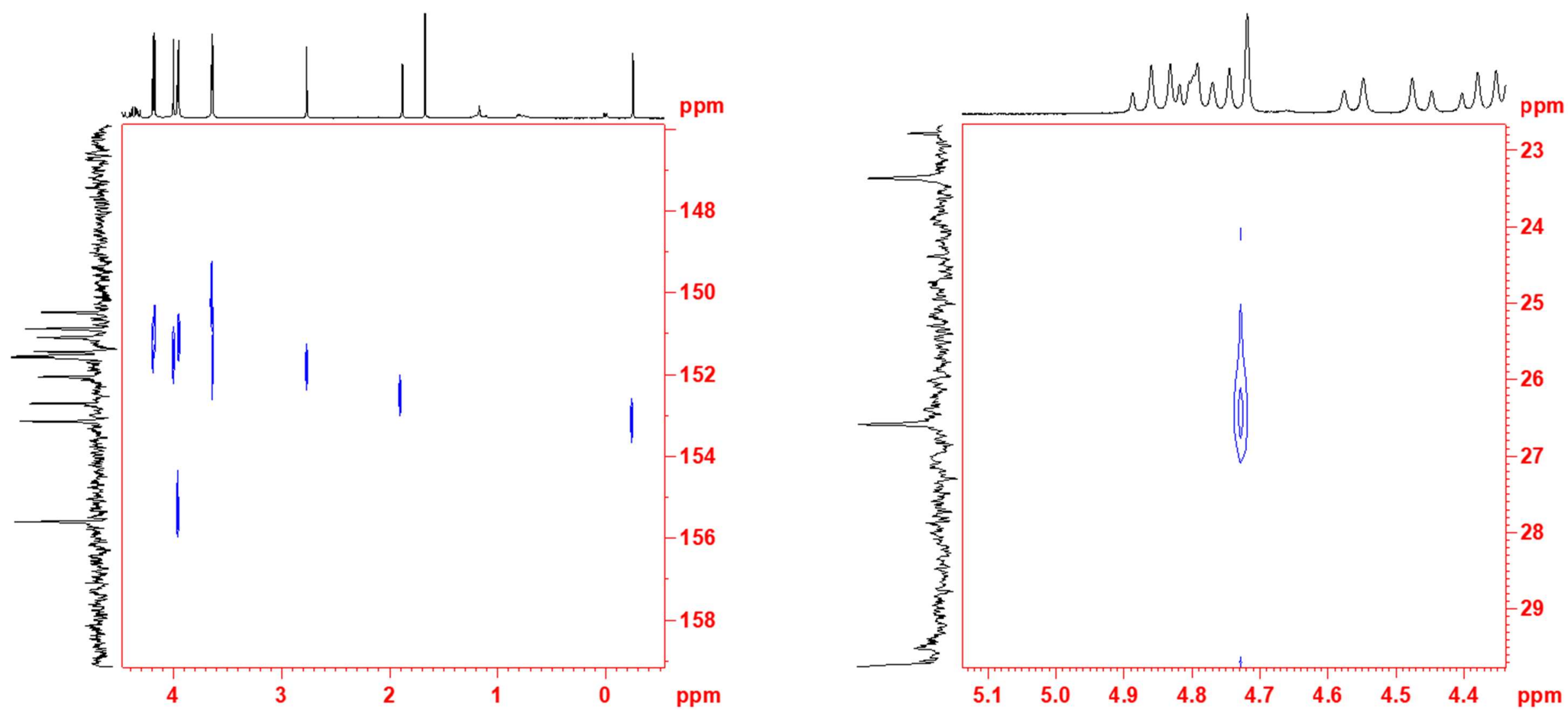

Figure S13: Significant portions of 2D-HMBC spectrum of $2\left(\mathrm{CD}_{2} \mathrm{Cl}_{2}, 600 \mathrm{MHz}, 213 \mathrm{~K}\right)$. 


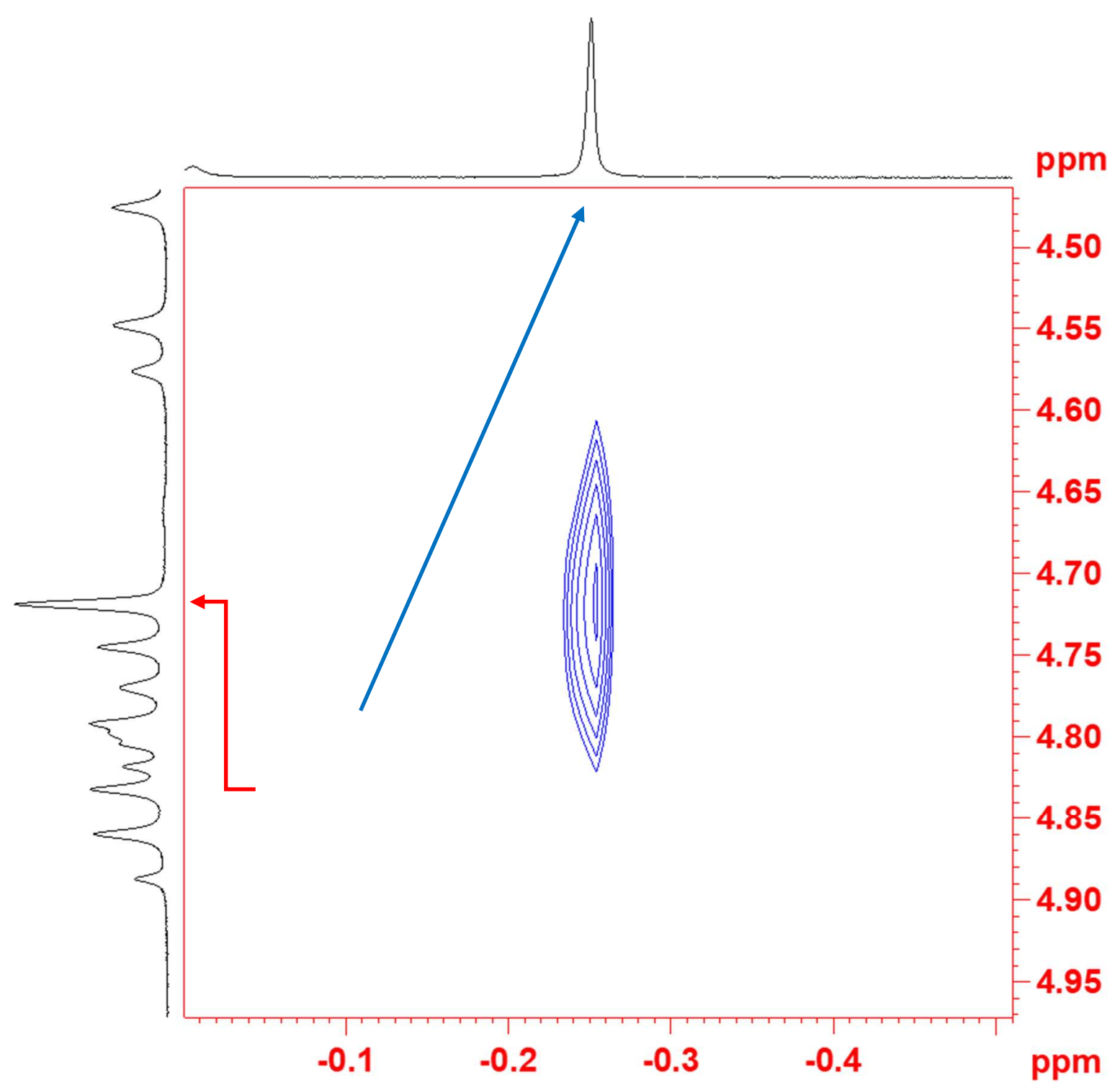

Figure S14: Significant portion of NOESY spectrum of $2\left(\mathrm{CD}_{2} \mathrm{Cl}_{2}, 600 \mathrm{MHz}, 213 \mathrm{~K}\right)$. 


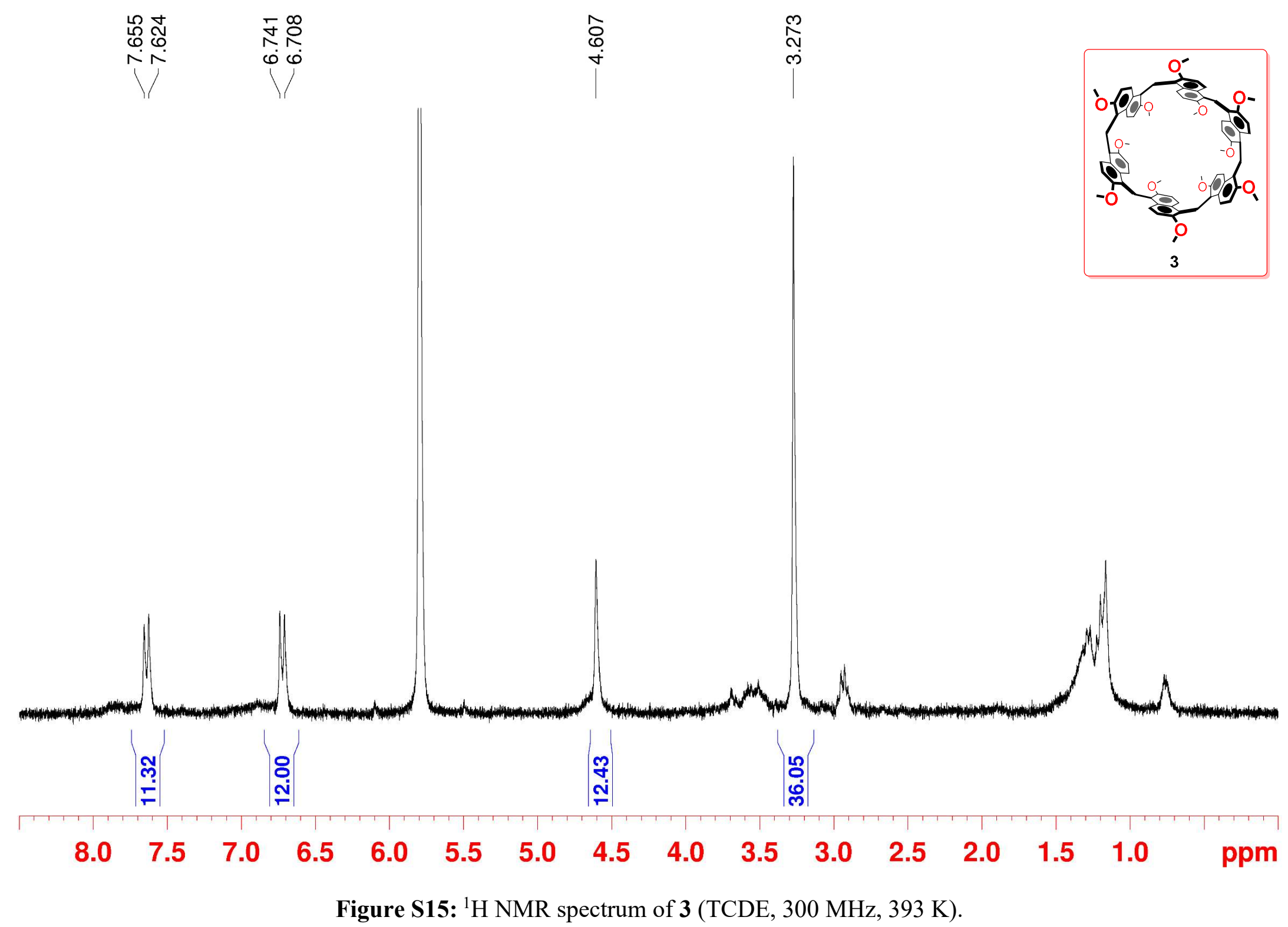




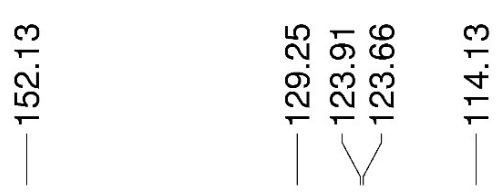

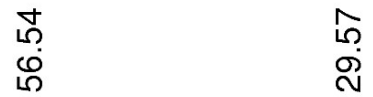
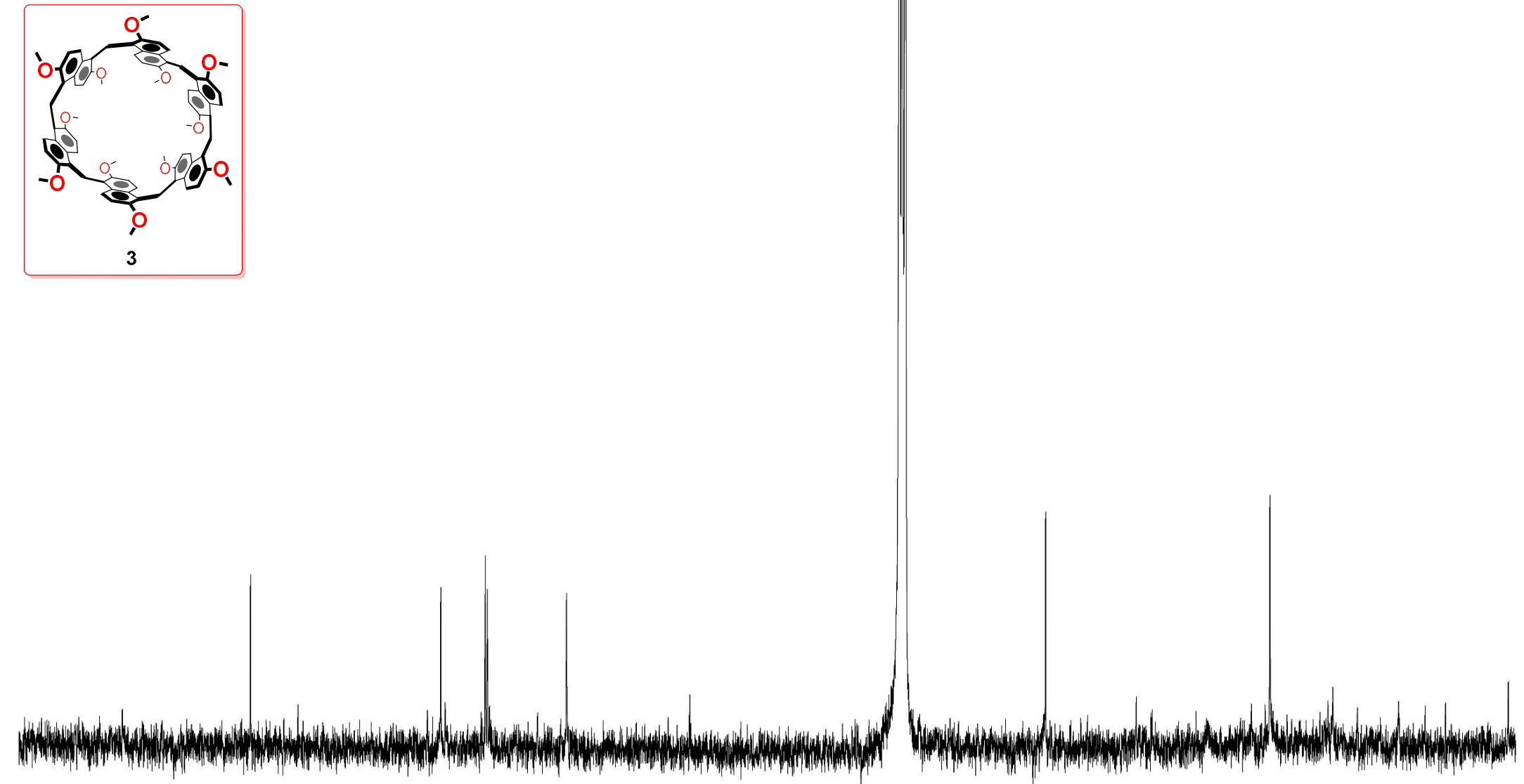

$\begin{array}{llllllllllllllllll}170 & 160 & 150 & 140 & 130 & 120 & 110 & 100 & 90 & 80 & 70 & 60 & 50 & 40 & 30 & 20 & \text { ppm }\end{array}$

Figure S16: ${ }^{13} \mathrm{C}$ NMR spectrum of 3 (TCDE, $\left.75 \mathrm{MHz}, 298 \mathrm{~K}\right)$. 


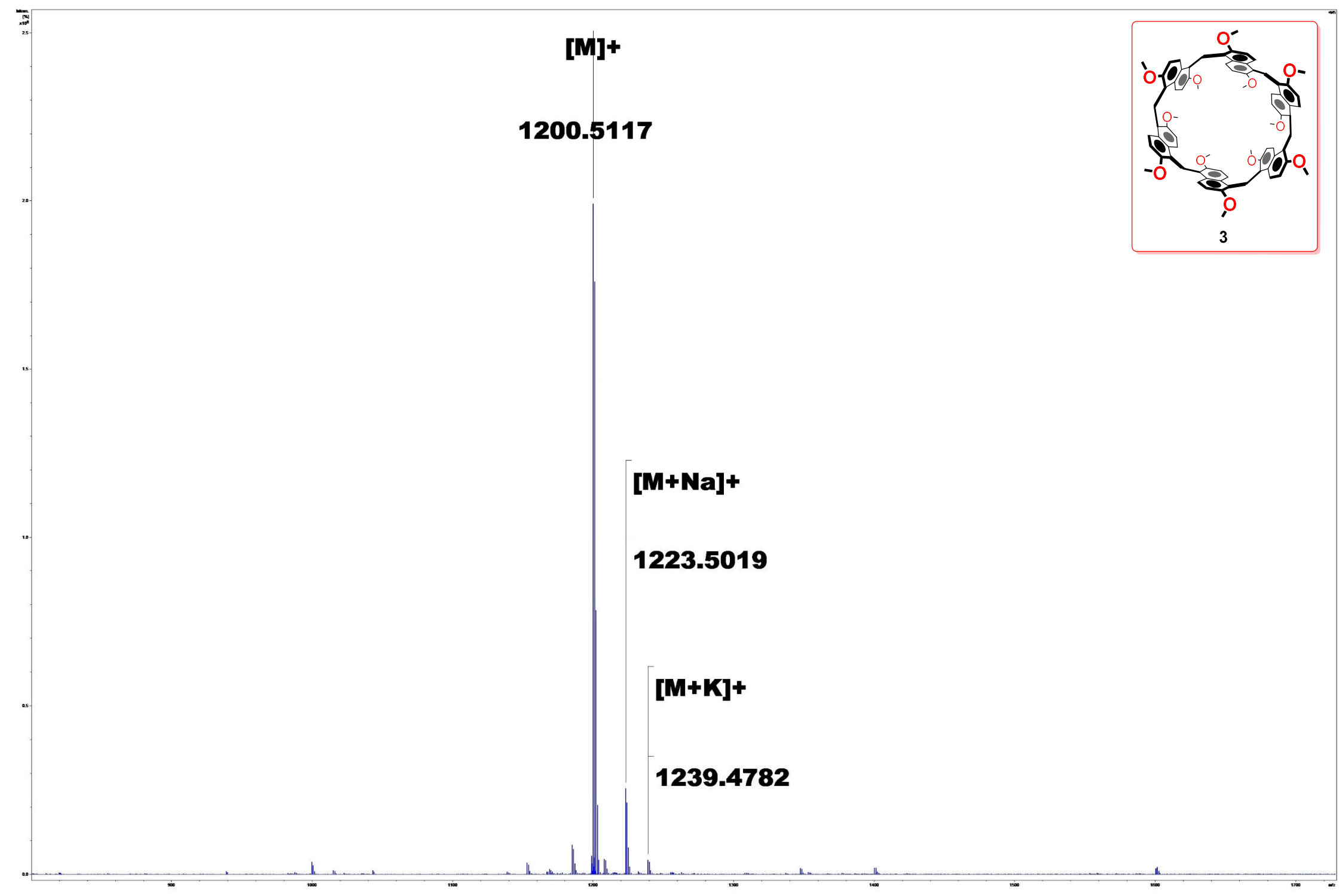

Figure S17: Significant portion of the HR MALDI FT-ICR mass spectrum of $3[\mathrm{M}]^{+}$. 


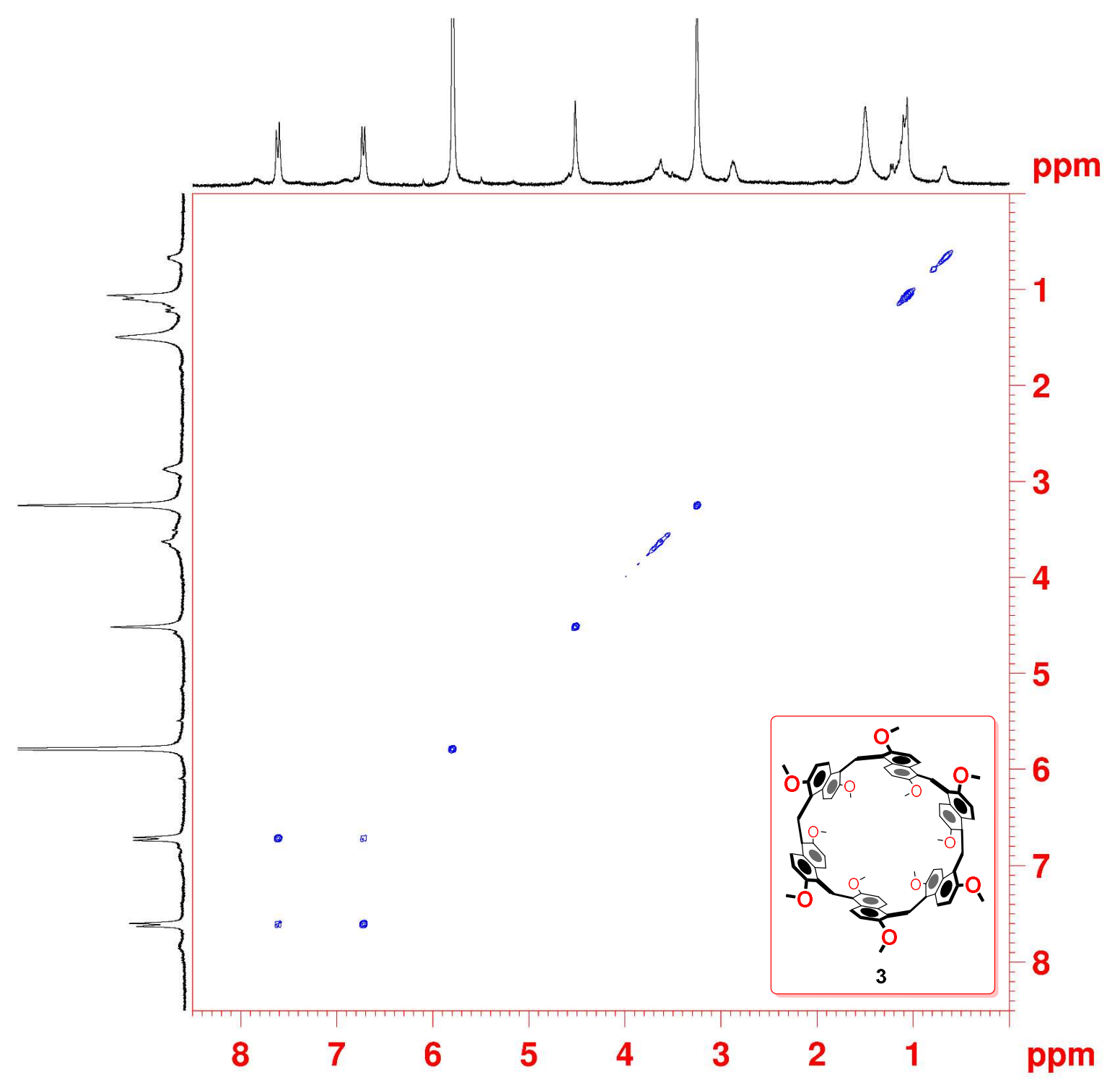

Figure S18: 2D-DQF COSY spectrum of 3 (TCDE, $400 \mathrm{MHz}, 298 \mathrm{~K}$ ). 


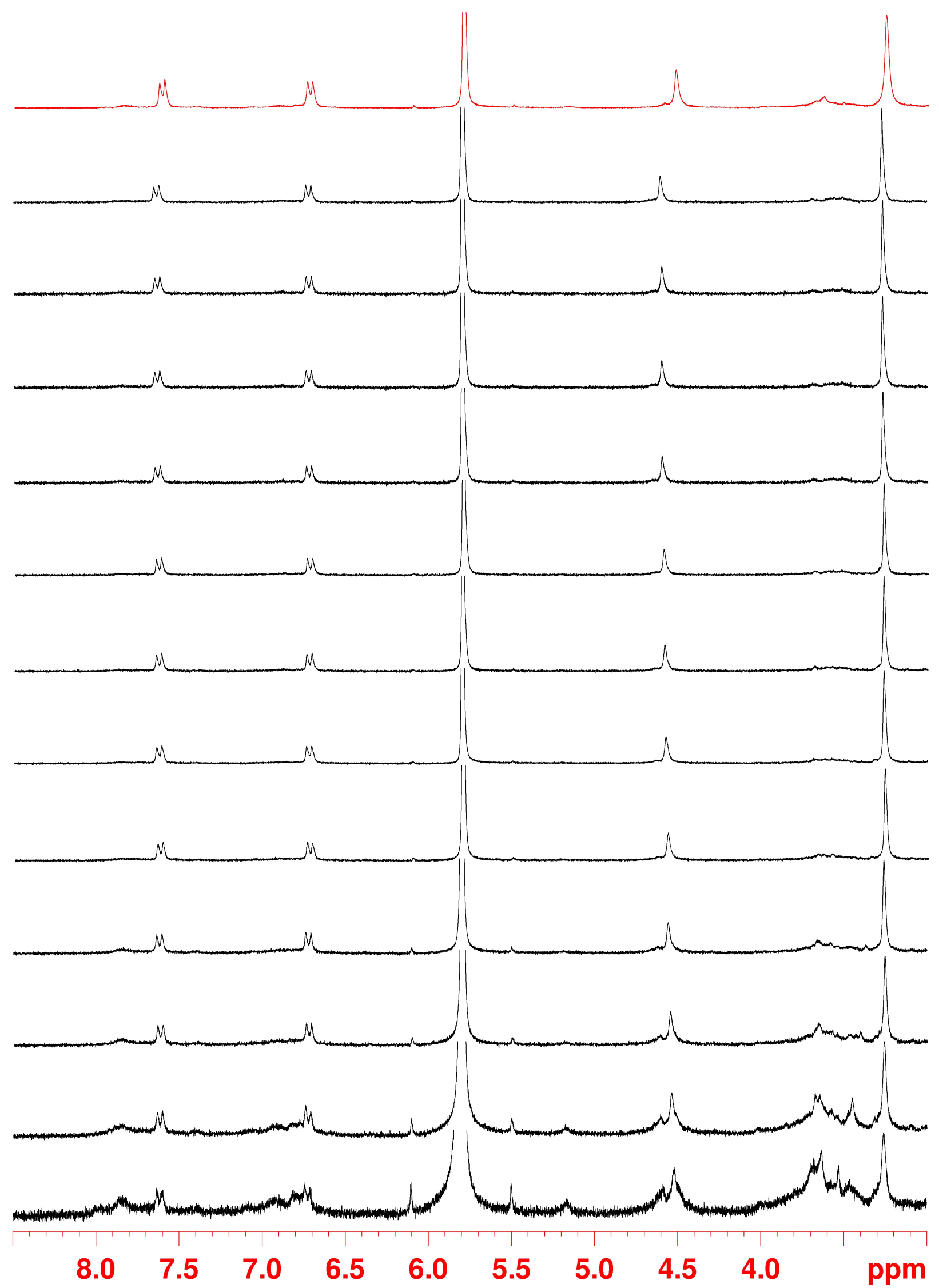

Figure S19: Relevant region of the ${ }^{1} \mathrm{H}$ NMR spectrum of 3 (300 MHz, TCDE) at (from bottom to top): $303,313,323,333,343,353,363,373,383$ and $393 \mathrm{~K}$; in red the spectrum at $298 \mathrm{~K}$ after high temperature acquisition. 


\section{Copies of 1D, 2D and HR Mass Spectra of Prismarene Complexes}

Copies of NMR and HR Mass Spectra of $4^{2+} \subset 1$

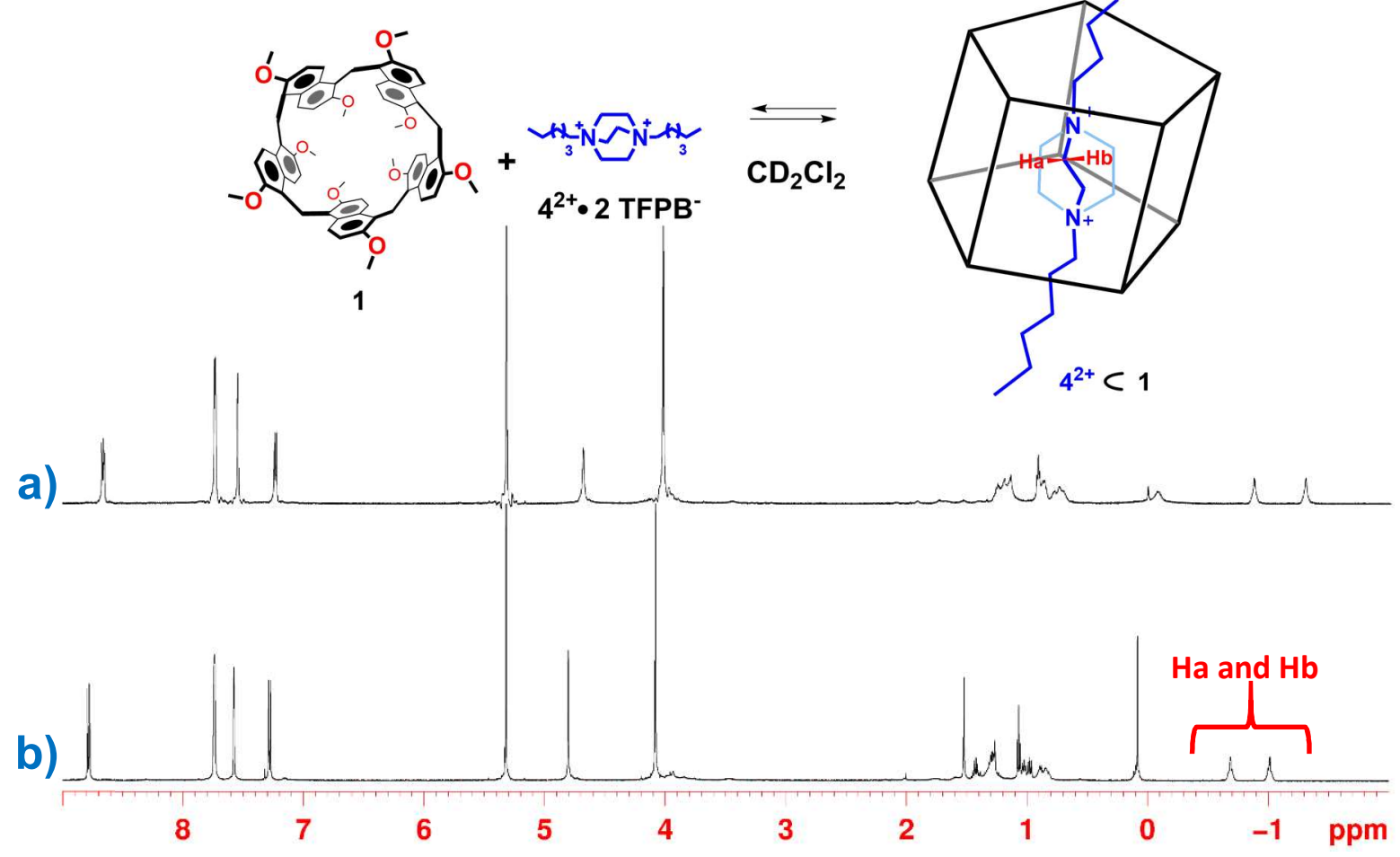

Figure S20: ${ }^{1} \mathrm{H}$ NMR spectra of an equimolar solution of $\mathbf{1}$ and $\mathbf{4}^{\mathbf{2} \cdot} \mathbf{2}$ TFPB- $^{-}$(a) at $183 \mathrm{~K}$ and (b) at $298 \mathrm{~K}\left(600 \mathrm{MHz}, \mathrm{CD}_{2} \mathrm{Cl}_{2}\right)$.

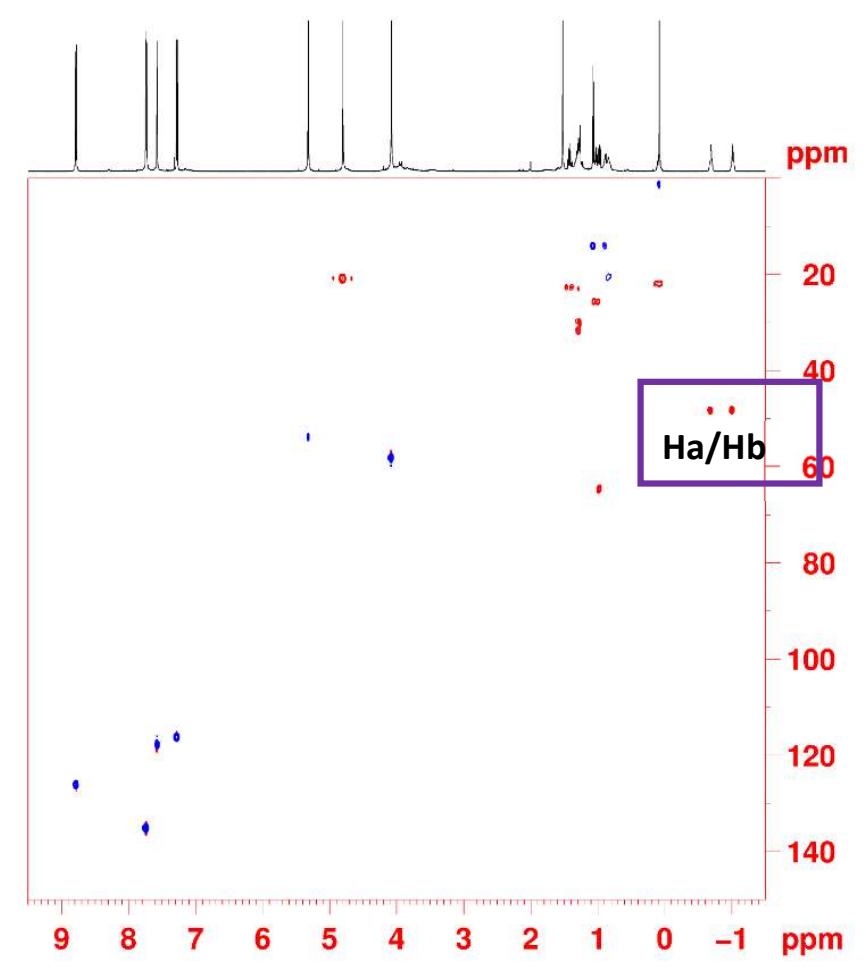

Figure S21: 2D-HSQC spectrum of $\mathbf{4}^{2+} \subset \mathbf{1}\left(\mathrm{CD}_{2} \mathrm{Cl}_{2}, 600 \mathrm{MHz}, 298 \mathrm{~K}\right)$. 


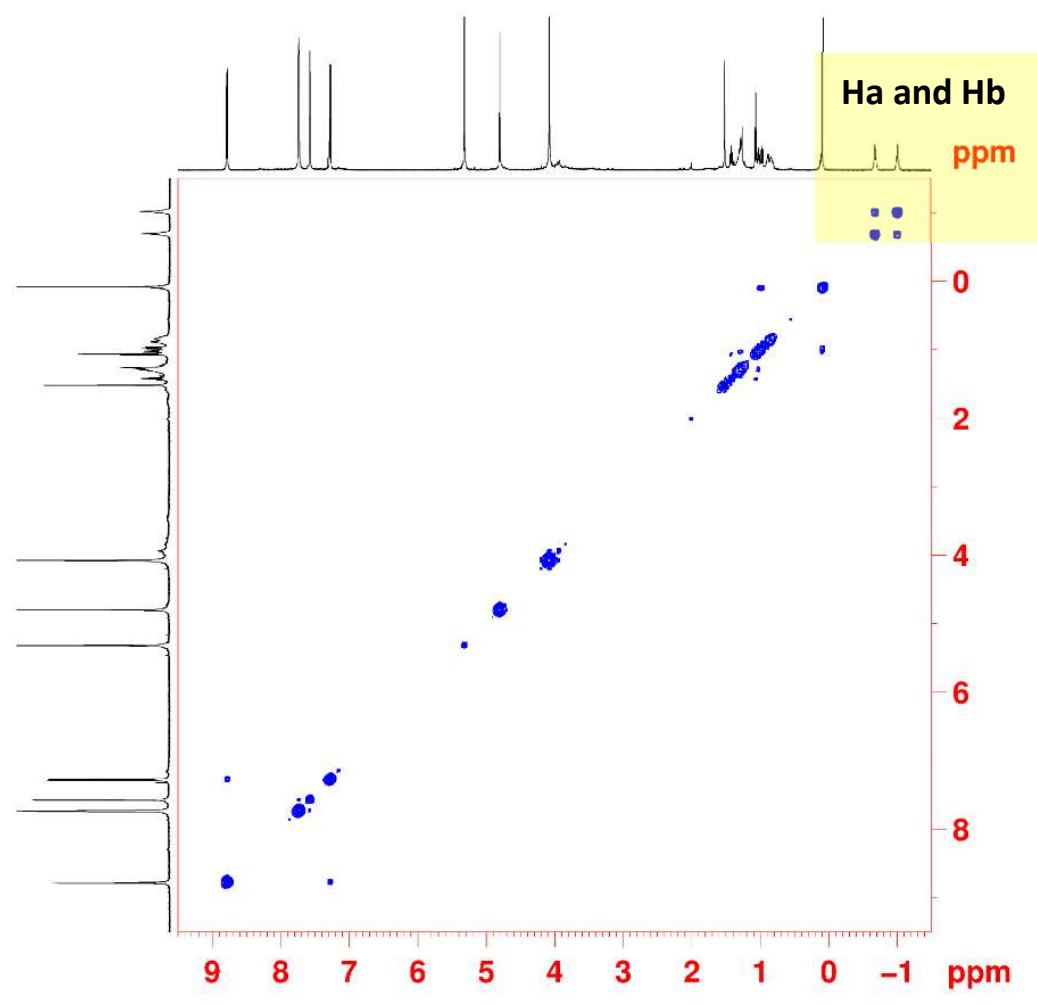

Figure S22: 2D-DQF COSY spectrum of $4^{2+} \subset \mathbf{1}\left(\mathrm{CD}_{2} \mathrm{Cl}_{2}, 600 \mathrm{MHz}, 298 \mathrm{~K}\right)$.

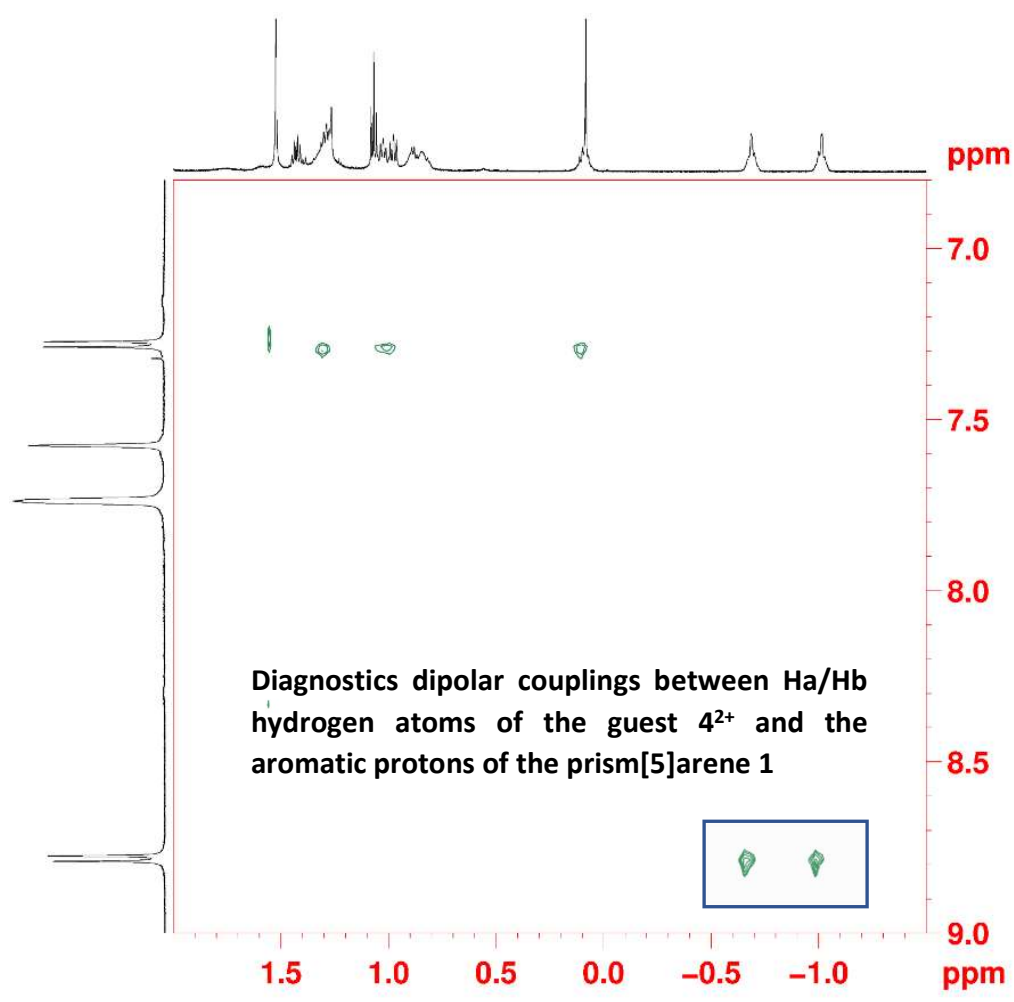

Figure S23: Significant portion of 2D-NOESY spectrum of $\mathbf{4}^{2+} \subset \mathbf{1}\left(\mathrm{CD}_{2} \mathrm{Cl}_{2}, 600 \mathrm{MHz}, 298 \mathrm{~K}\right)$. 


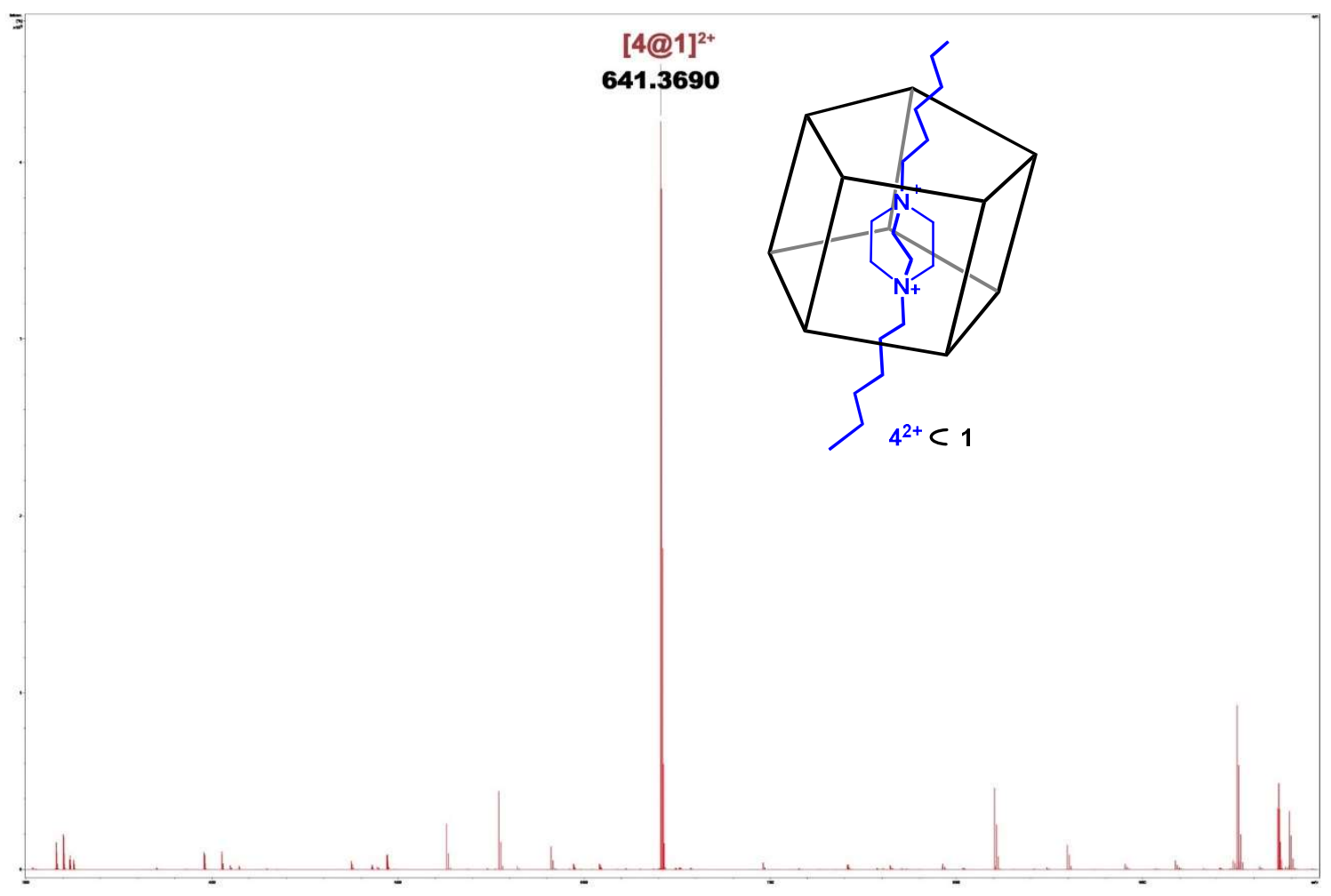

Figure S24: Significant portion of the HR ESI FT-ICR mass spectrum of $\left[4 \subset \mathbf{1}^{2+}\right.$. 
Copies of NMR and HR Mass Spectra of $5^{+} \subset 1$

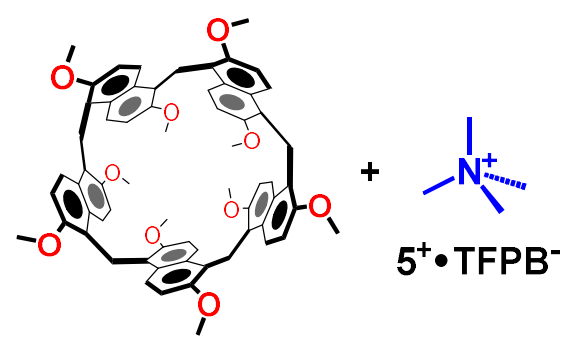

1

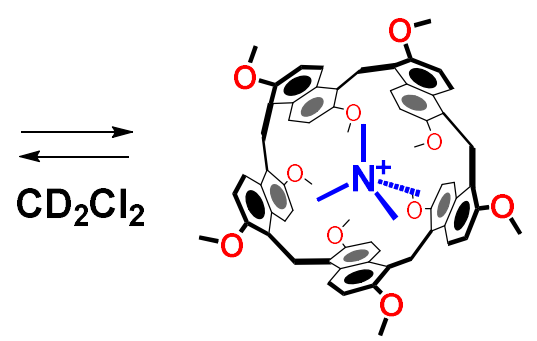

$5^{+}<1$

a)

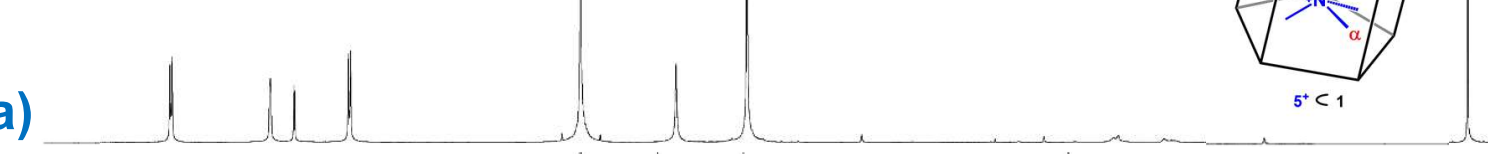

b)

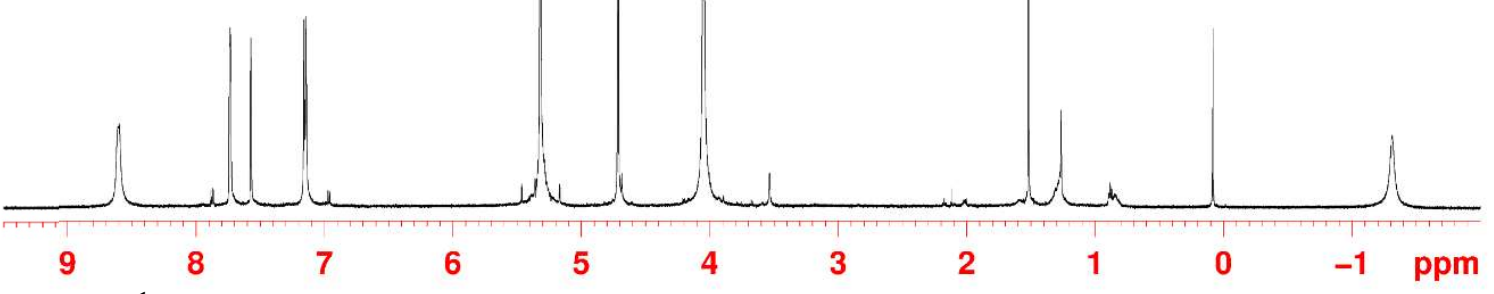

Figure S25: ${ }^{1} \mathrm{H}$ NMR spectra of an equimolar solution of $\mathbf{1}$ and $\mathbf{5}^{+}$. TFPB'$^{-}$(a) at $183 \mathrm{~K}$ and (b) at $298 \mathrm{~K}\left(600 \mathrm{MHz}, \mathrm{CD}_{2} \mathrm{Cl}_{2}\right)$.

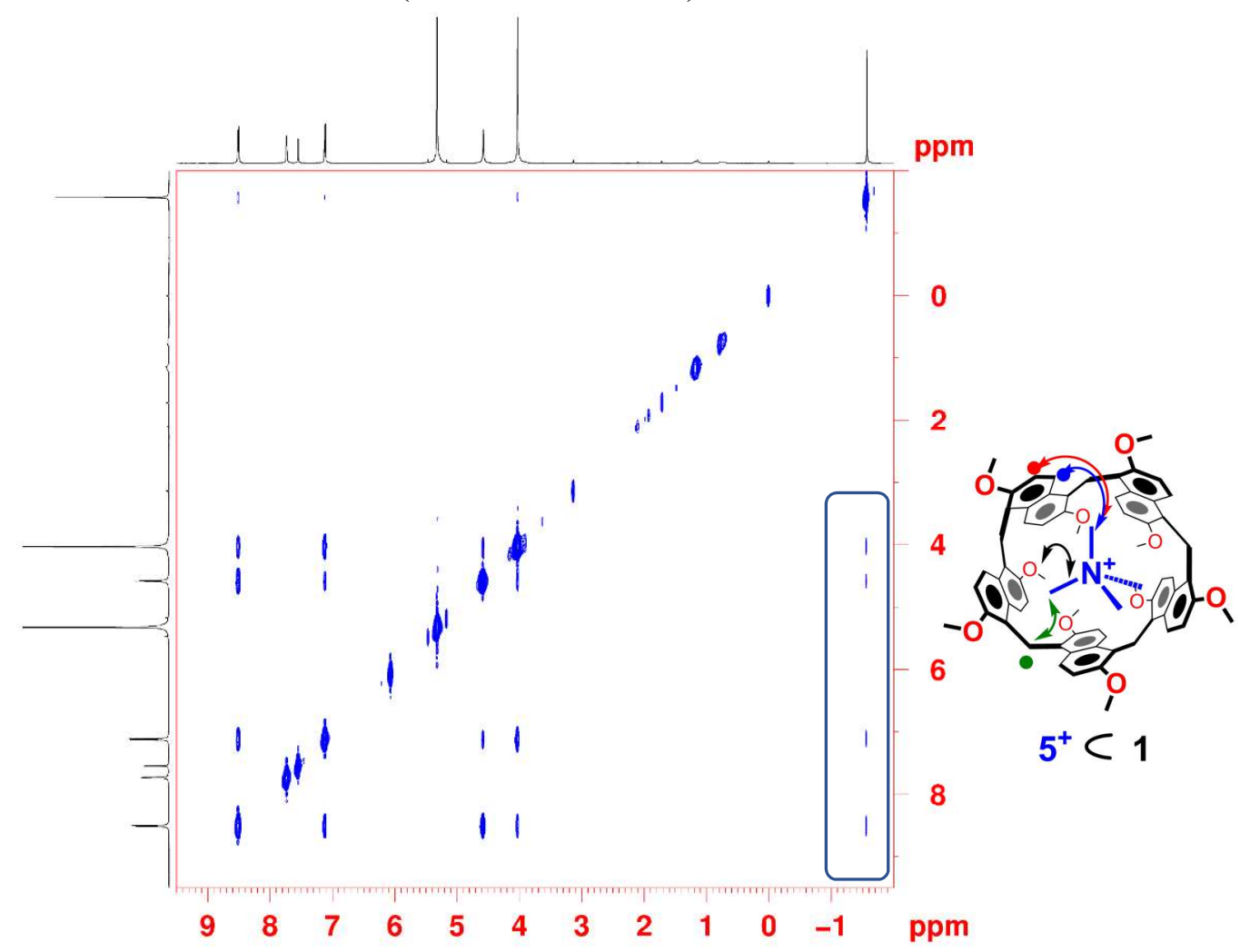

Figure S26: 2D-NOESY spectrum of $\mathbf{5}^{+} \subset \mathbf{1}\left(\mathrm{CD}_{2} \mathrm{Cl}_{2}, 600 \mathrm{MHz}, 183 \mathrm{~K}\right)$. 


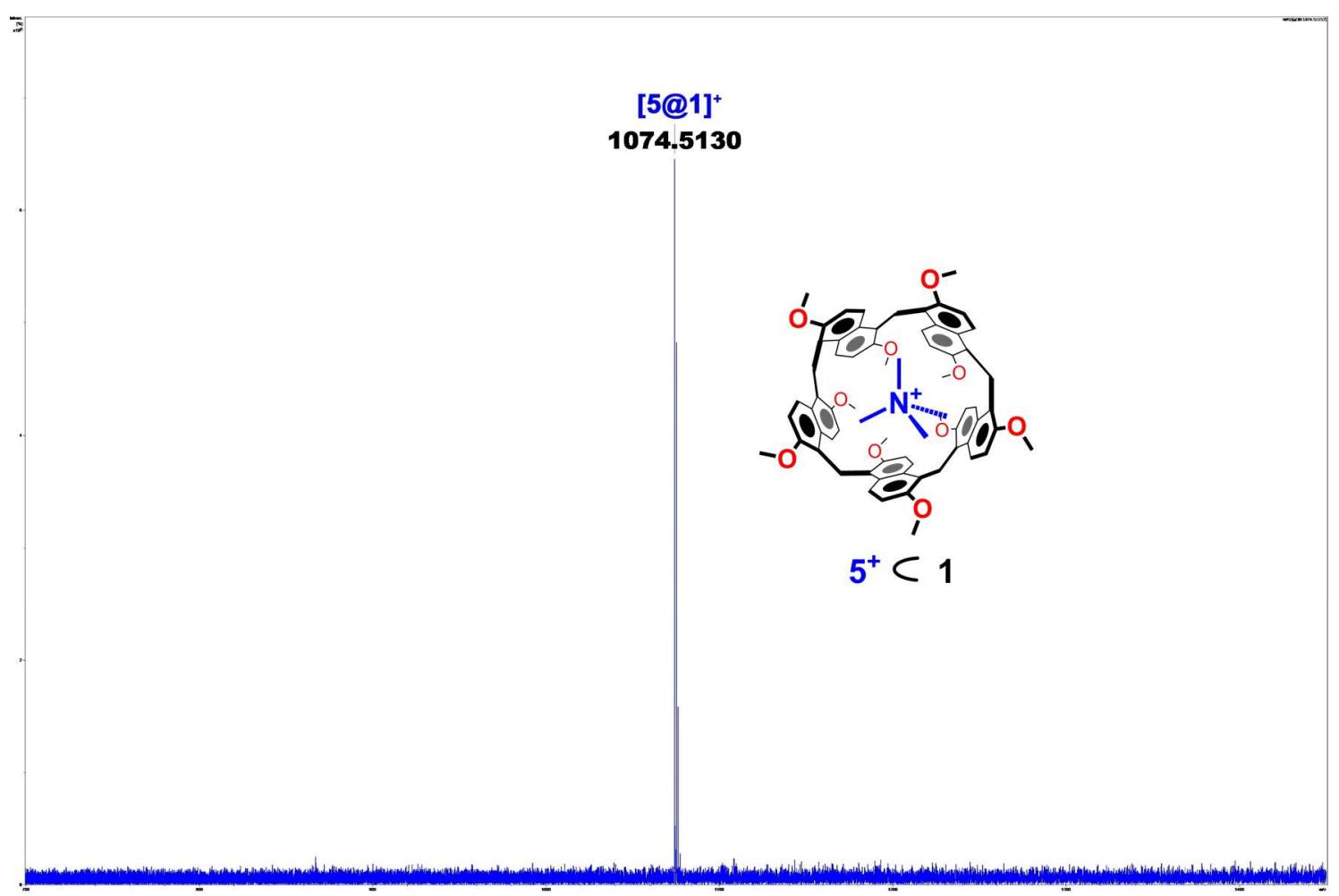

Figure S27: Significant portion of the HR ESI FT-ICR mass spectrum of [5 $\subset \mathbf{1}]^{+}$. 


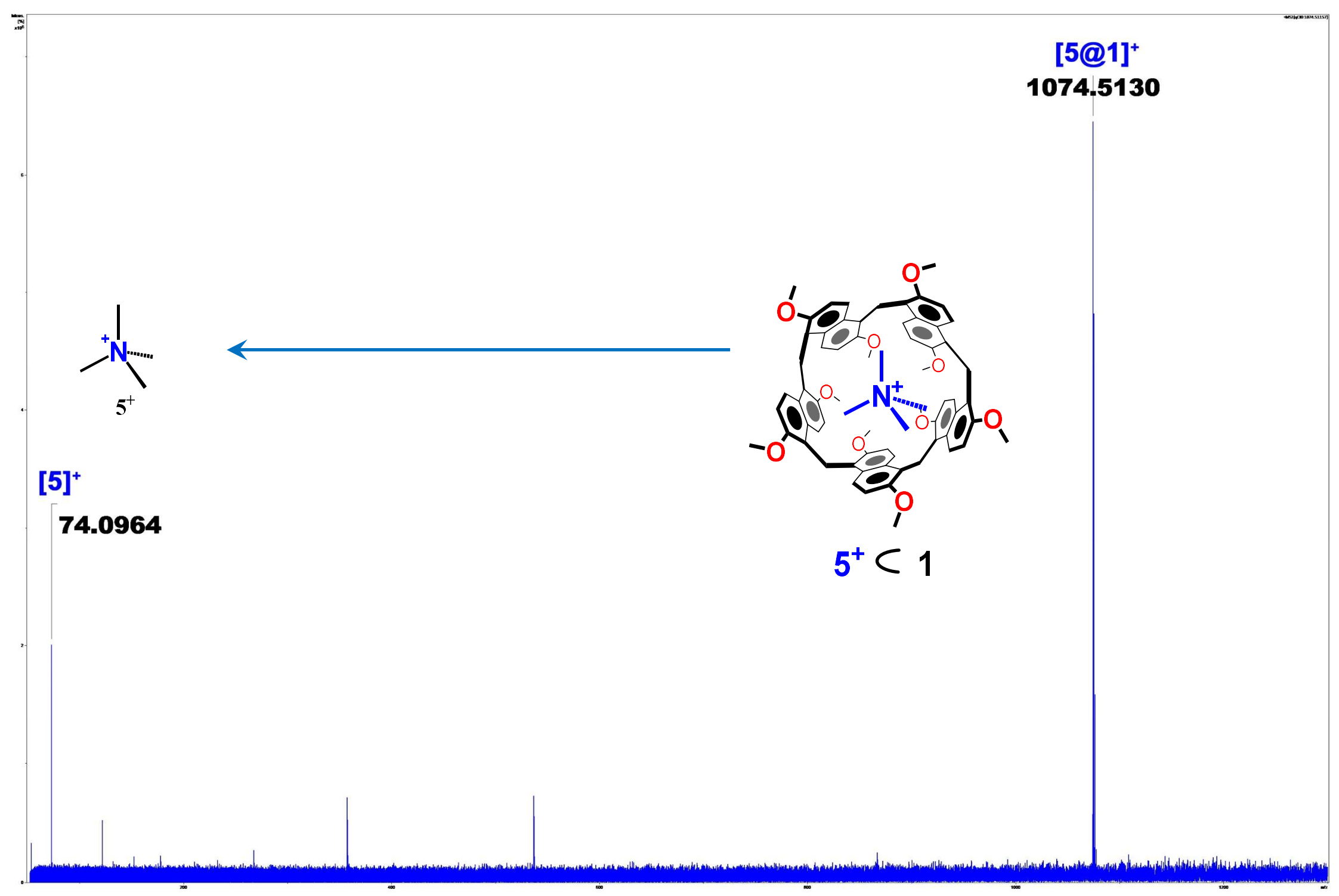

Figure S28: HR ESI-FT-ICR-CID mass spectrum of $[\mathbf{5} \subset \mathbf{1}]^{+}$. 
a)

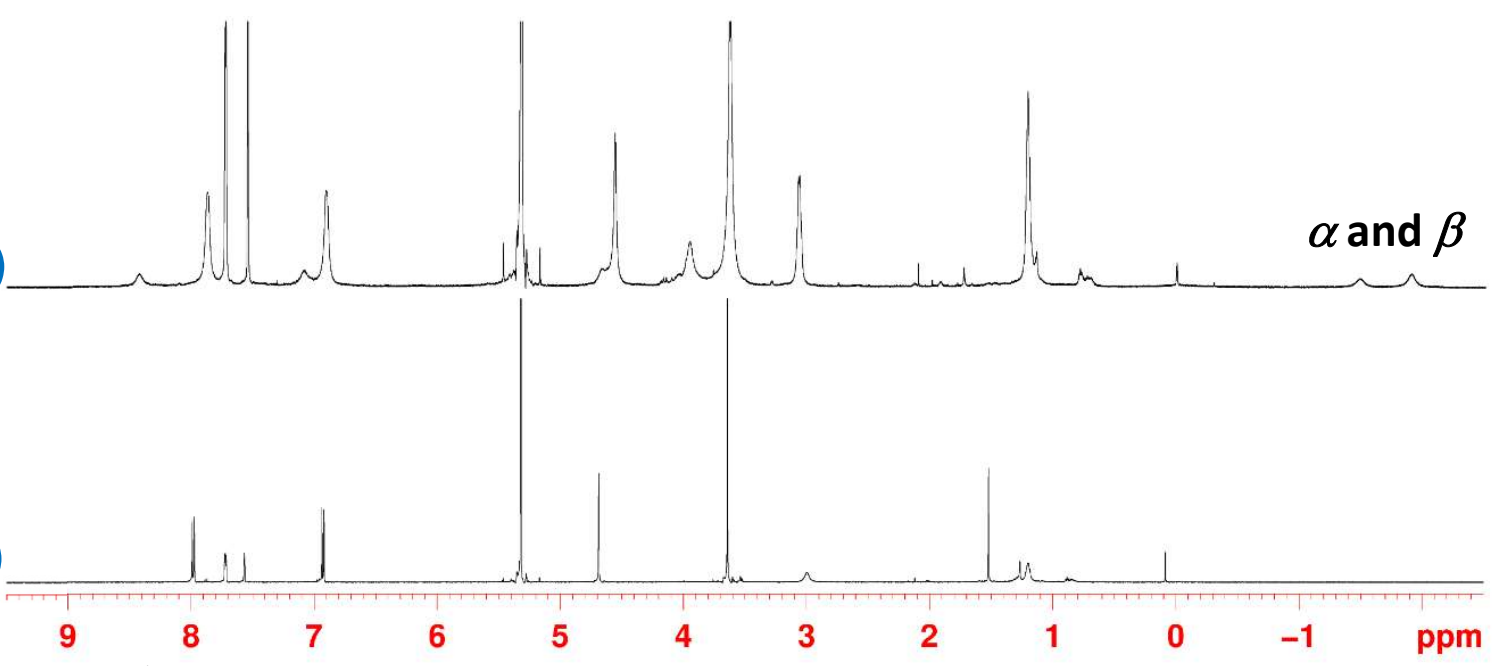

Figure S29: ${ }^{1} \mathrm{H}$ NMR spectra of an equimolar solution of $\mathbf{1}$ and $\mathbf{6}^{+} \cdot$ TFPB'$^{-}$(a) at $183 \mathrm{~K}$ and (b) at $298 \mathrm{~K}\left(600 \mathrm{MHz}, \mathrm{CD}_{2} \mathrm{Cl}_{2}\right)$.

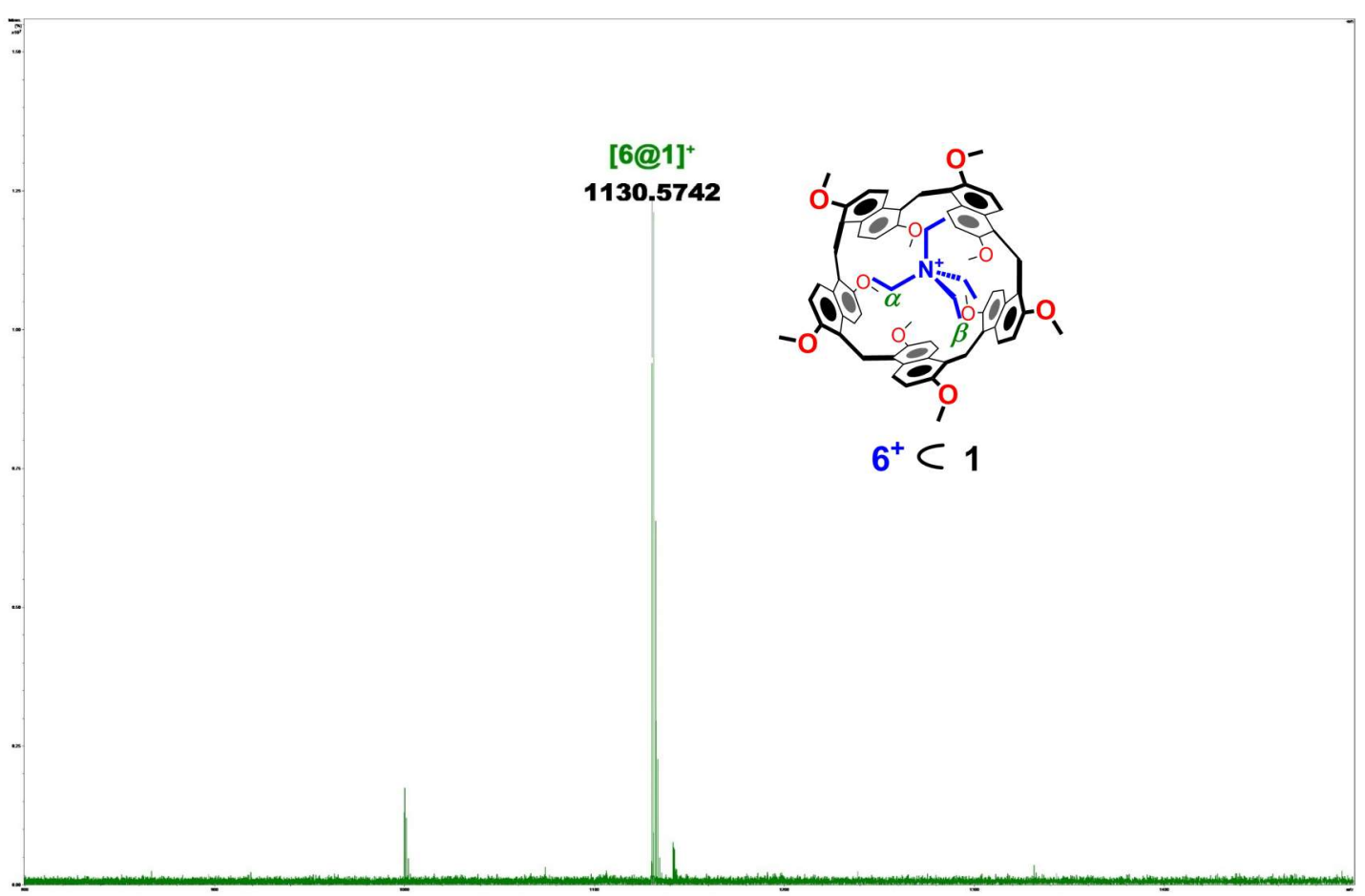

Figure S30: Significant portion of the HR ESI FT-ICR mass spectrum of $[\mathbf{6} \subset \mathbf{1}]^{+}$. 
Copies of NMR and HR Mass Spectra of $7^{+} \subset 1$

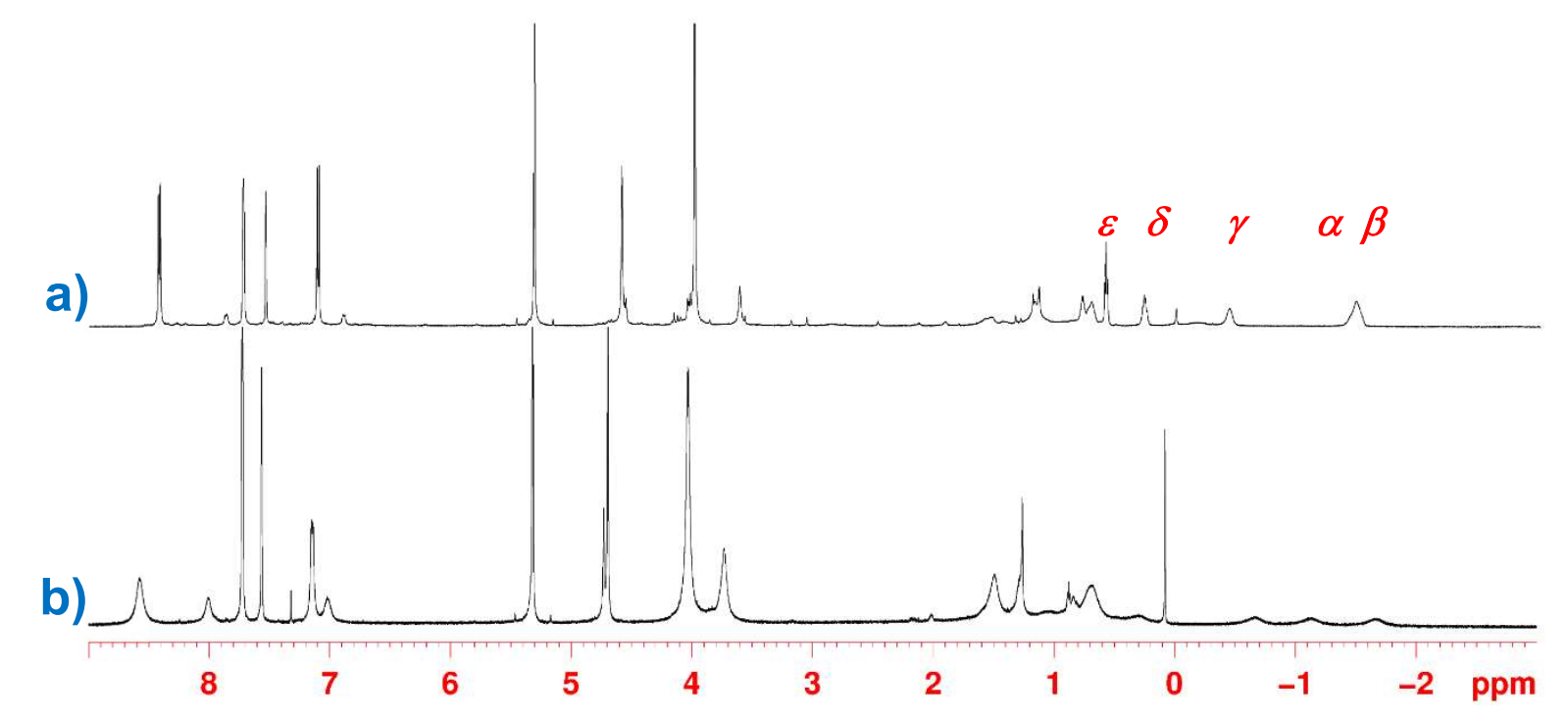

Figure S31: ${ }^{1} \mathrm{H}$ NMR spectra of an equimolar solution of 1 and $7^{+} \cdot$ TFPB $^{-}$(a) at $183 \mathrm{~K}$ and (b) at $298 \mathrm{~K}\left(600 \mathrm{MHz}, \mathrm{CD}_{2} \mathrm{Cl}_{2}\right)$. 

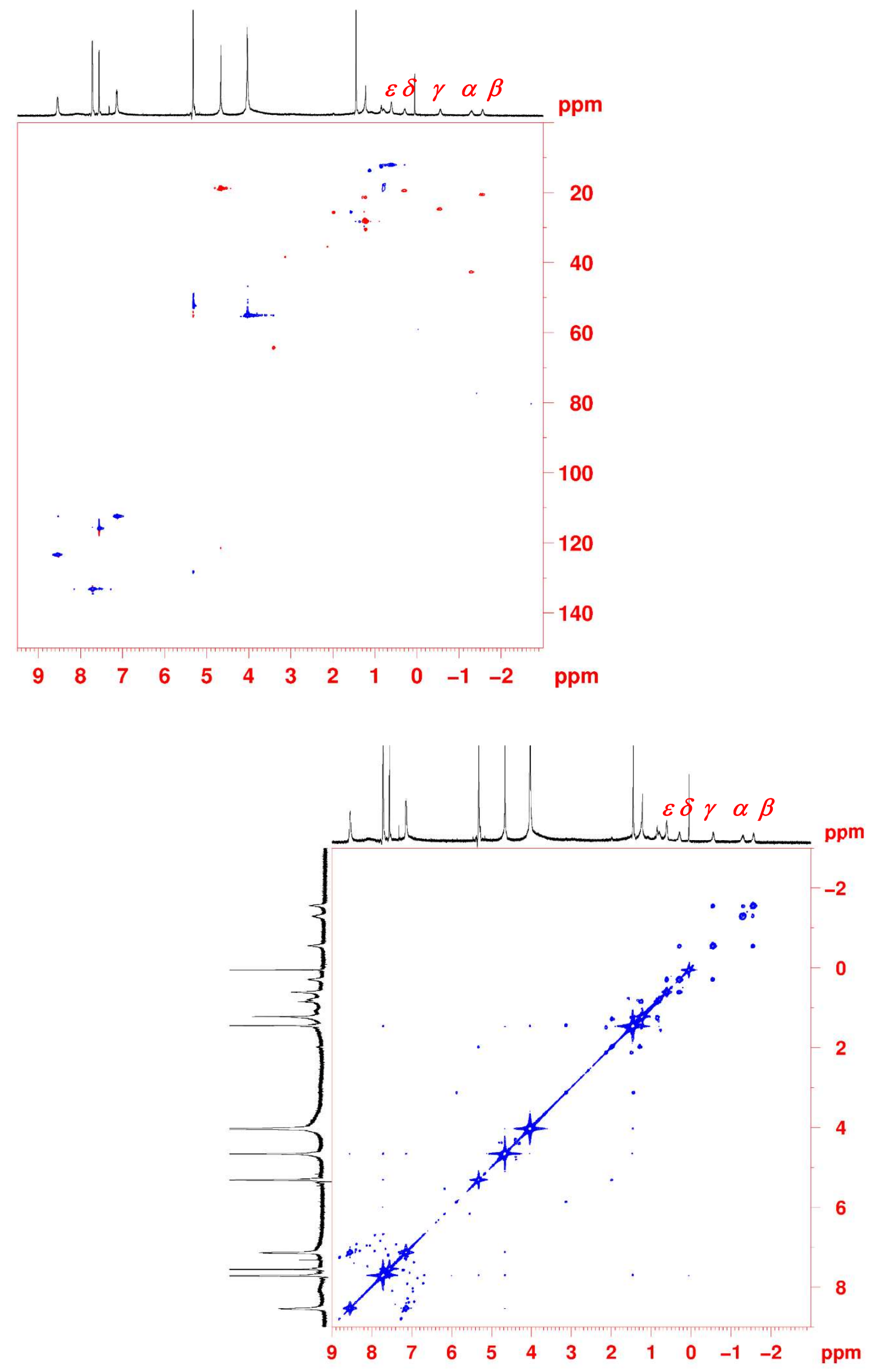

Figure S32: 2D-HSQC and 2D-DQF COSY spectra of $7^{+} \subset \mathbf{1}\left(\mathrm{CD}_{2} \mathrm{Cl}_{2}, 600 \mathrm{MHz}, 253 \mathrm{~K}\right)$. 


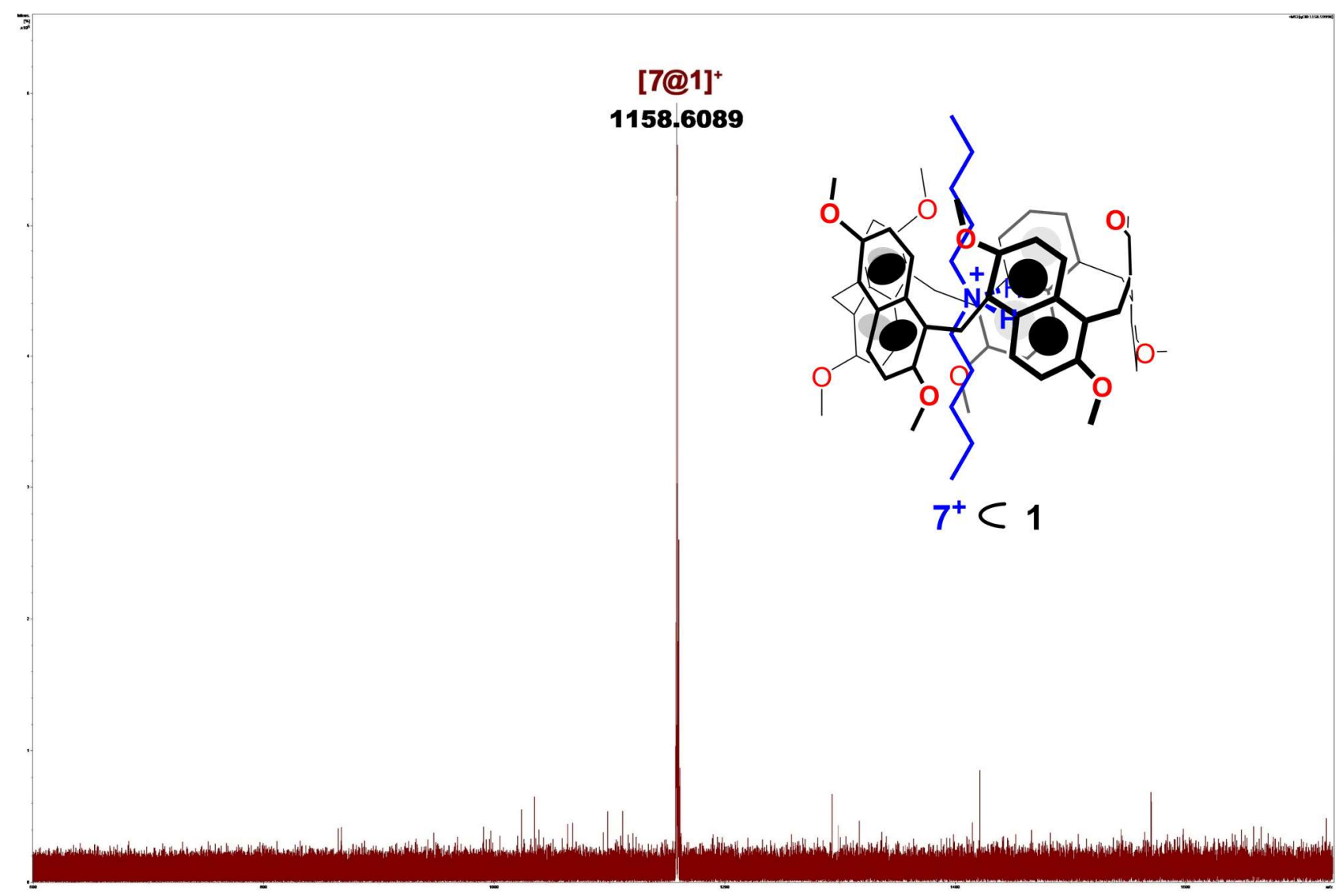

Figure S33: Significant portion of the HR ESI FT-ICR mass spectrum of $[7 \subset 1]^{+}$. 
Copies of NMR and HR Mass Spectra of $8^{+} \subset 1$
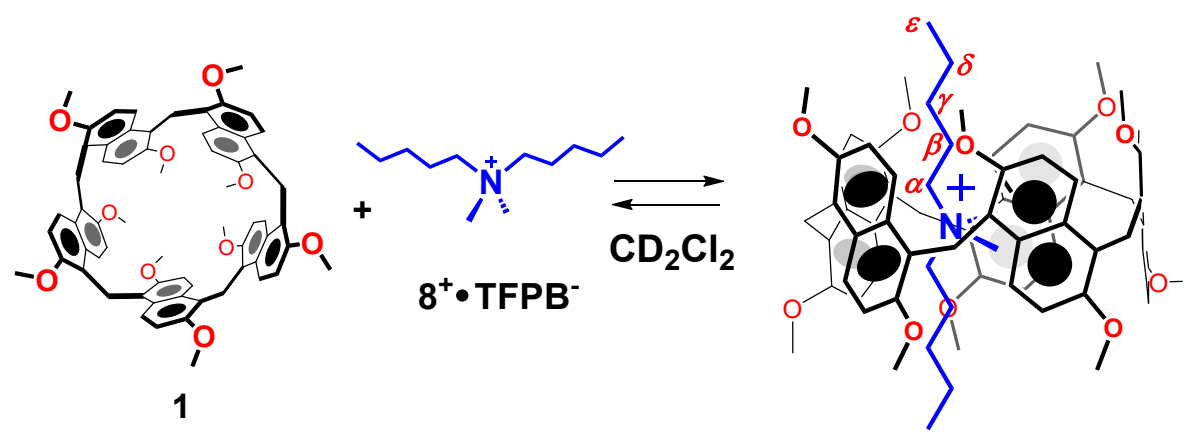

$$
8^{+}<1
$$

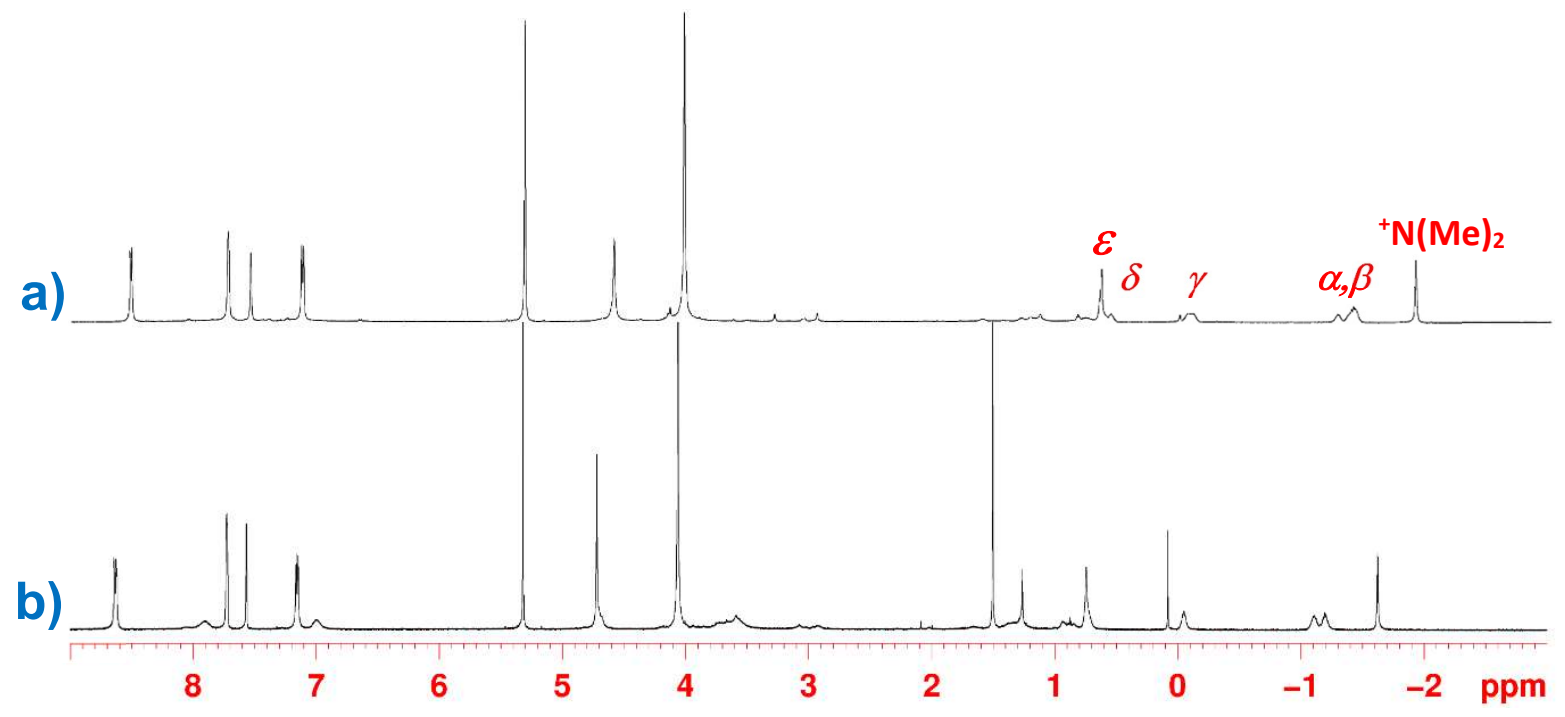

Figure S34: ${ }^{1} \mathrm{H}$ NMR spectra of an equimolar solution of $\mathbf{1}$ and $\mathbf{8}^{+} \cdot$ TFPB- $^{-}$(a) at $183 \mathrm{~K}$ and (b) at $298 \mathrm{~K}\left(600 \mathrm{MHz}, \mathrm{CD}_{2} \mathrm{Cl}_{2}\right)$. 


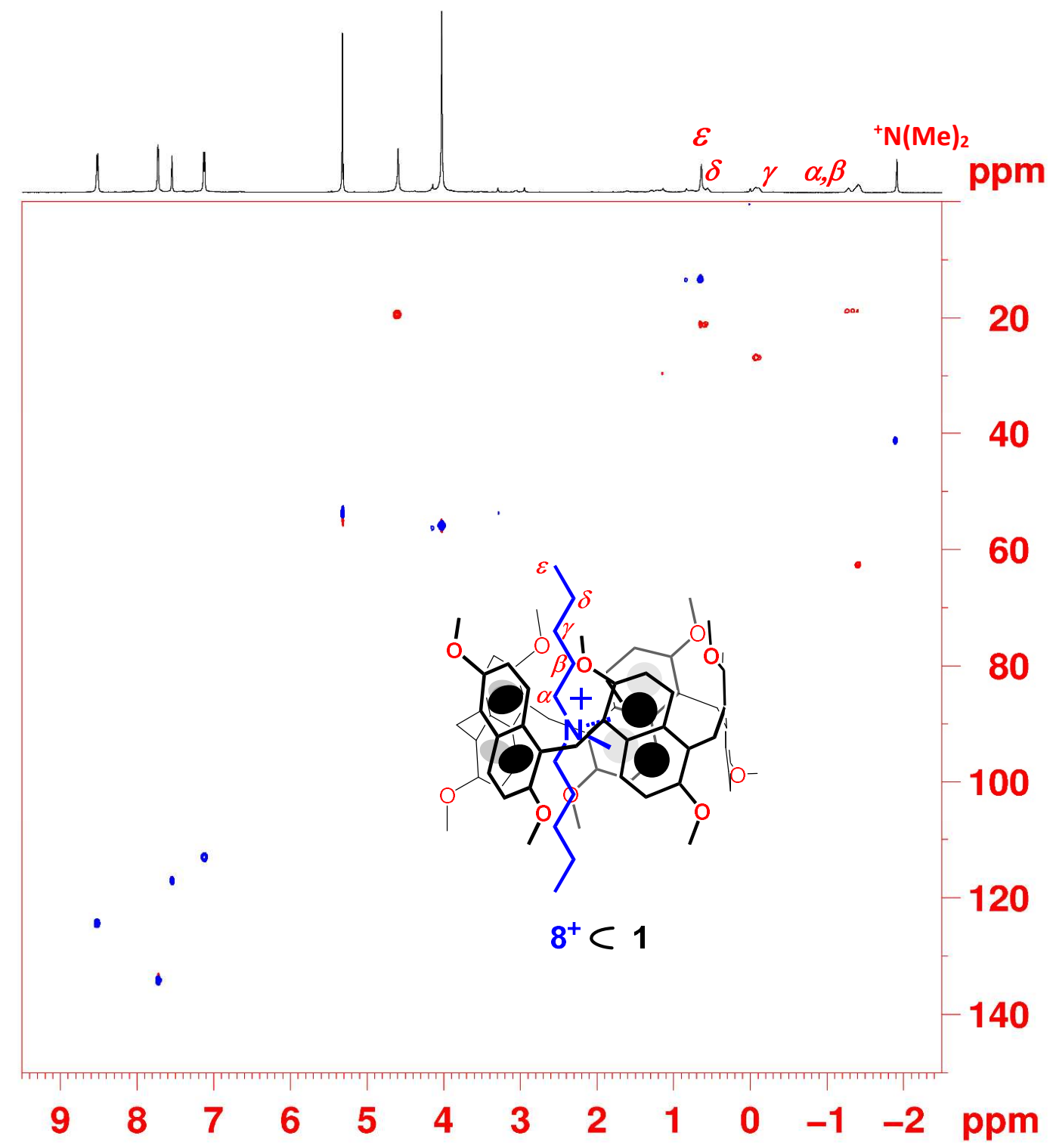

Figure S35: 2D-HSQC spectrum of $\mathbf{8}^{+} \subset \mathbf{1}\left(\mathrm{CD}_{2} \mathrm{Cl}_{2}, 600 \mathrm{MHz}, 253 \mathrm{~K}\right)$. 


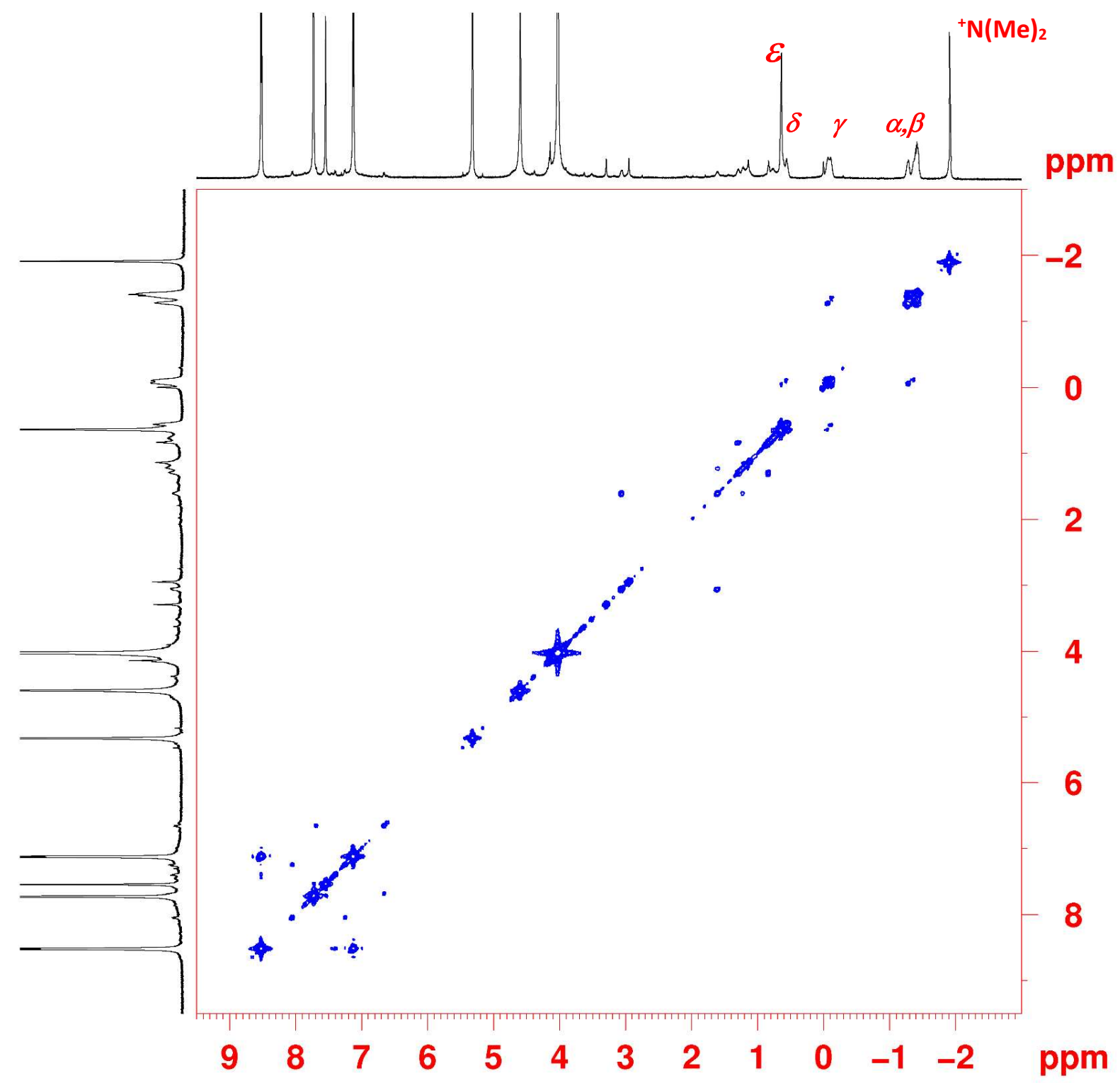

Figure S36: 2D-DQF COSY spectrum of $\mathbf{8}^{+} \subset \mathbf{1}\left(\mathrm{CD}_{2} \mathrm{Cl}_{2}, 600 \mathrm{MHz}, 183 \mathrm{~K}\right)$. 


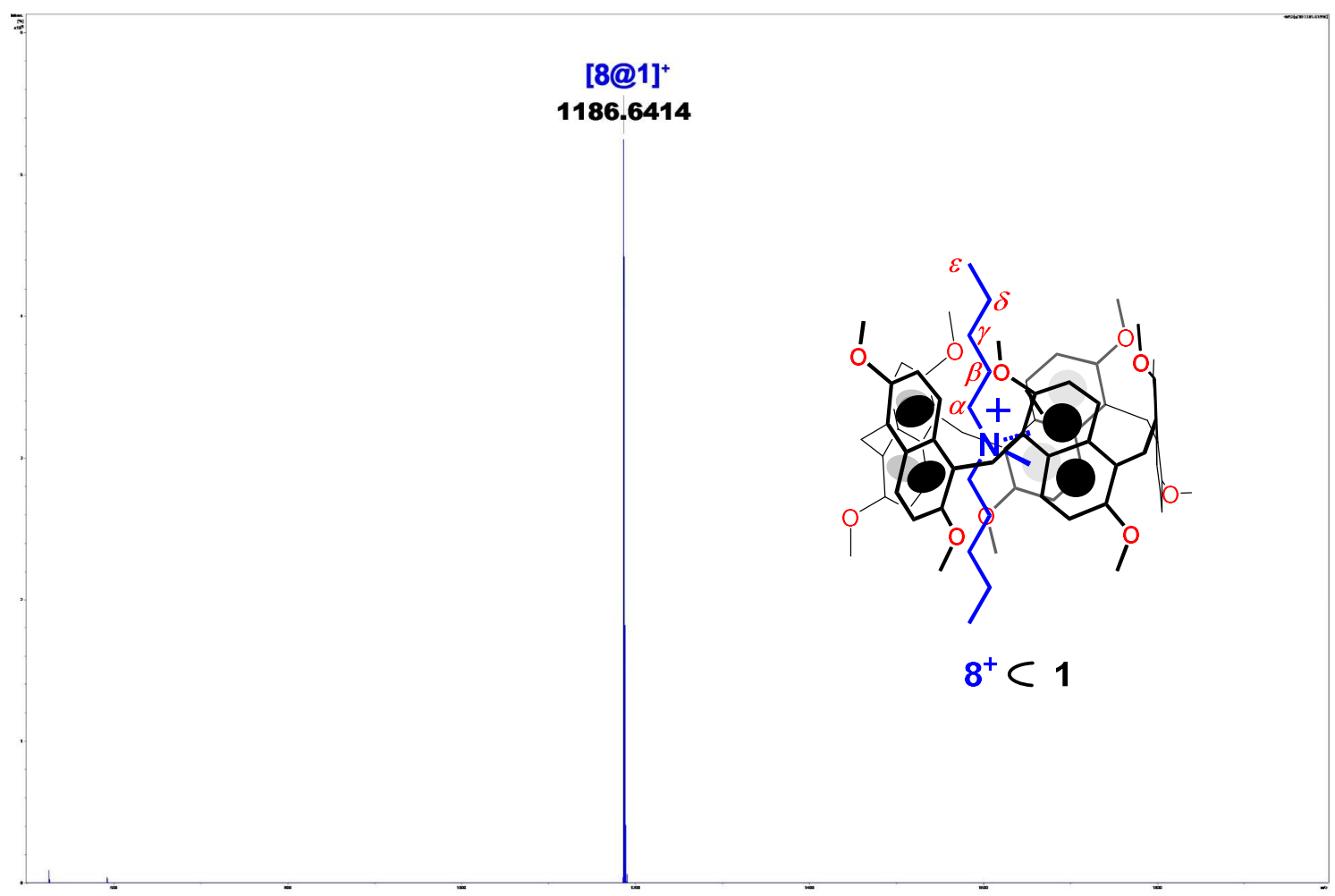

Figure S37: Significant portion of the HR ESI FT-ICR mass spectrum of $[\mathbf{8} \subset \mathbf{1}]^{+}$. 
Copies of NMR and HR Mass Spectra of $12^{+} \subset 1$

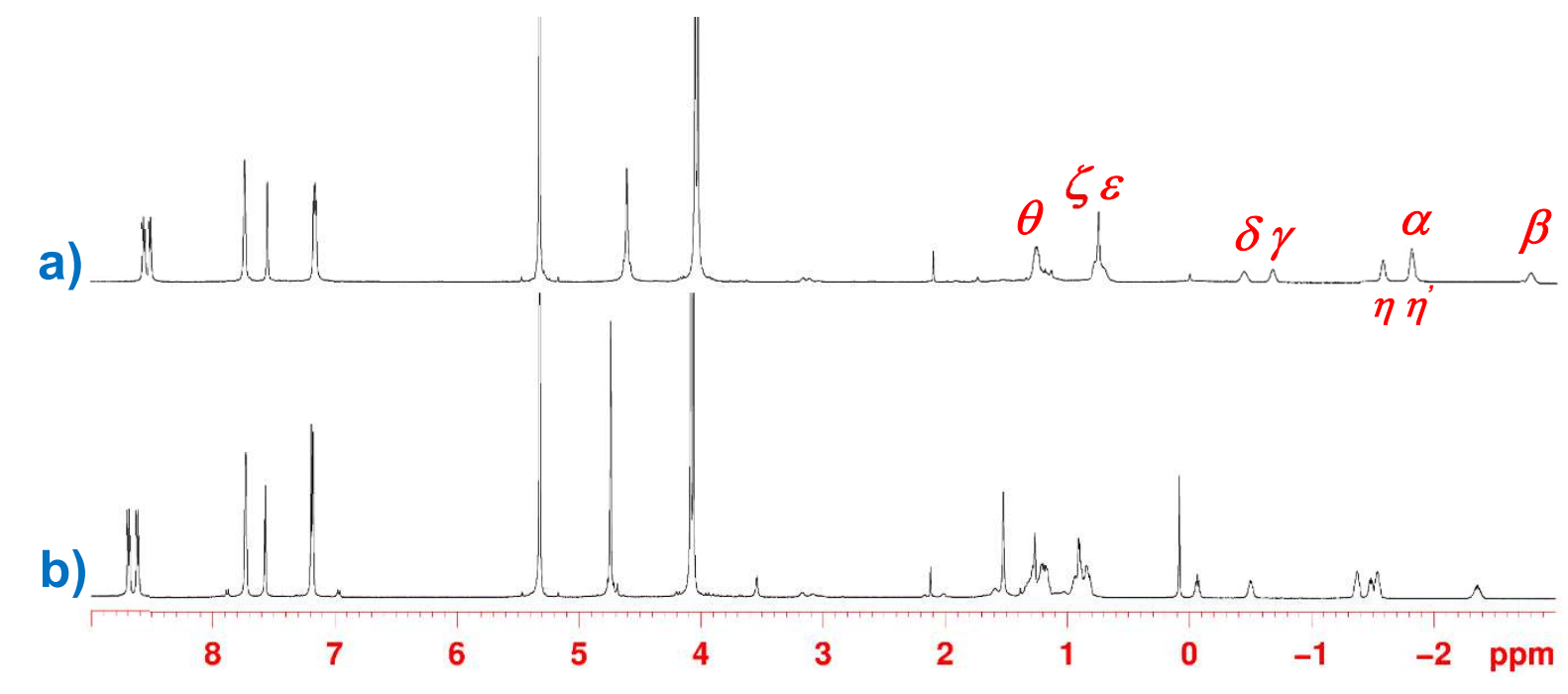

Figure S38: ${ }^{1} \mathrm{H}$ NMR spectra of an equimolar solution of $\mathbf{1}$ and $\mathbf{1 2}^{+} \cdot$ TFPB $^{-}$(a) at $183 \mathrm{~K}$ and (b) at $298 \mathrm{~K}\left(600 \mathrm{MHz}, \mathrm{CD}_{2} \mathrm{Cl}_{2}\right)$. 


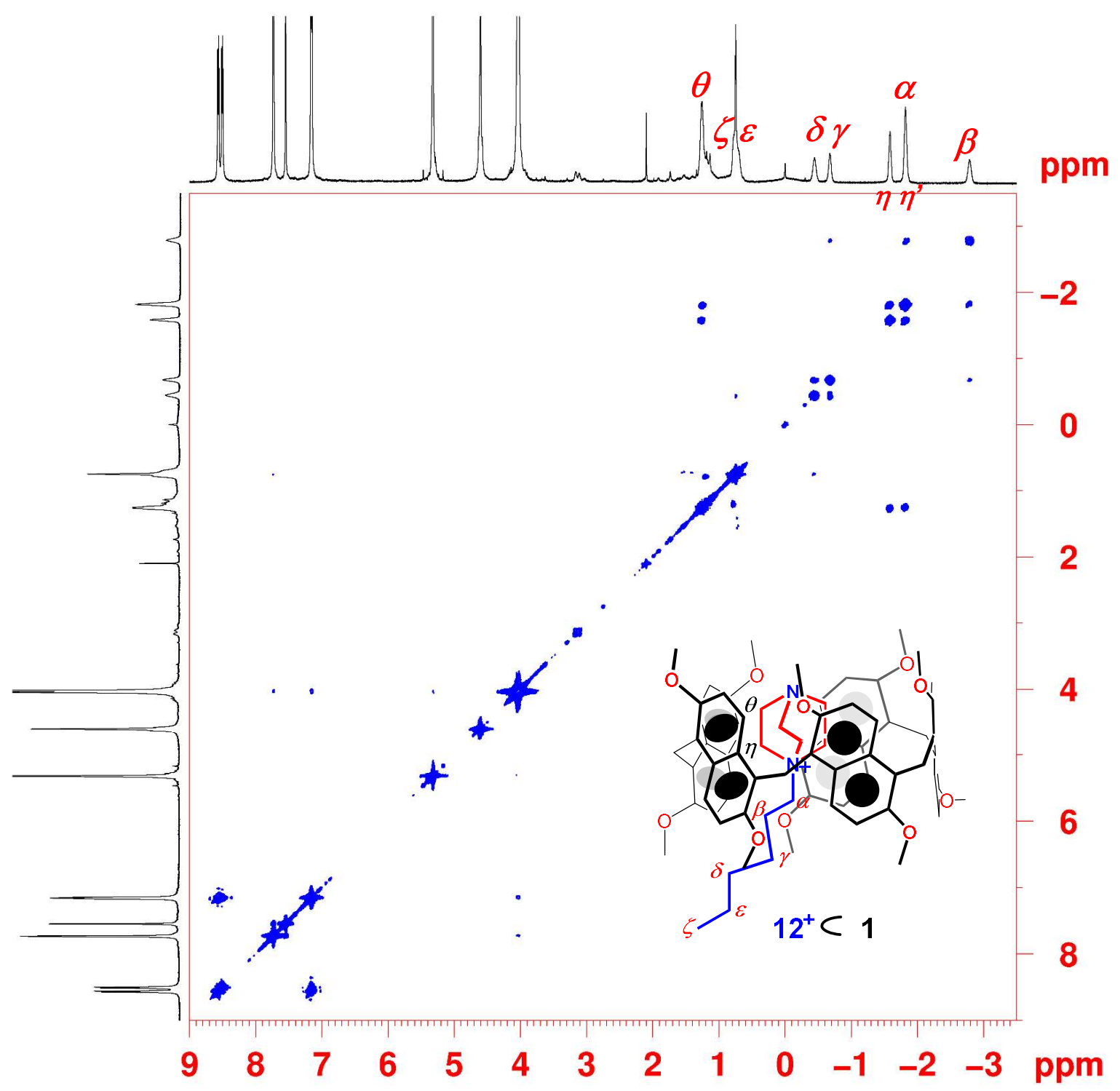

Figure S39: 2D-DQF COSY spectrum of $\mathbf{1 2}^{+} \subset \mathbf{1}\left(\mathrm{CD}_{2} \mathrm{Cl}_{2}, 600 \mathrm{MHz}, 183 \mathrm{~K}\right)$. 


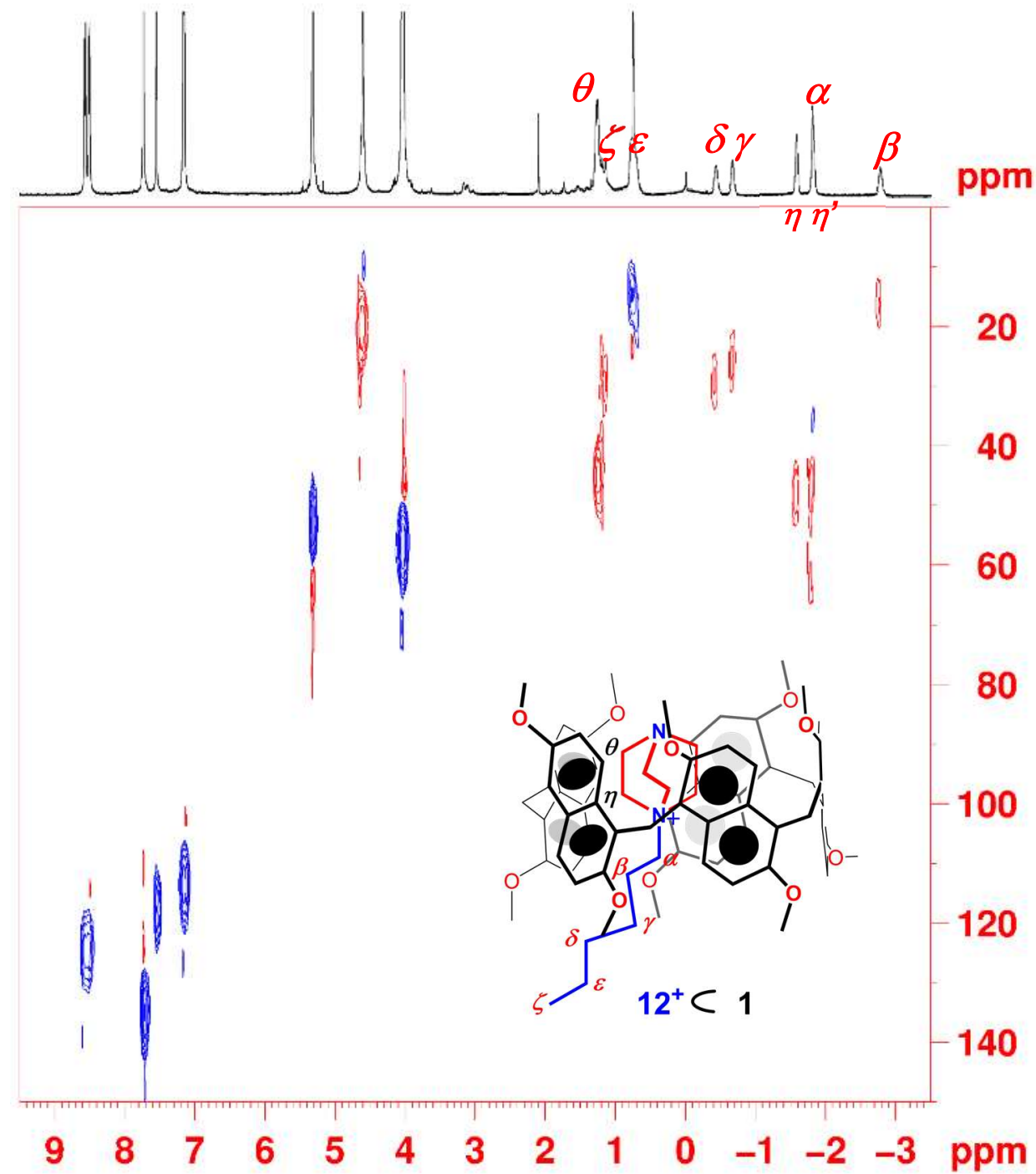

Figure S40: 2D-HSQC spectrum of $\mathbf{1 2}^{+} \subset \mathbf{1}\left(\mathrm{CD}_{2} \mathrm{Cl}_{2}, 600 \mathrm{MHz}, 183 \mathrm{~K}\right)$. 
Copies of NMR and HR Mass Spectra of $10^{2+} \subset 1$
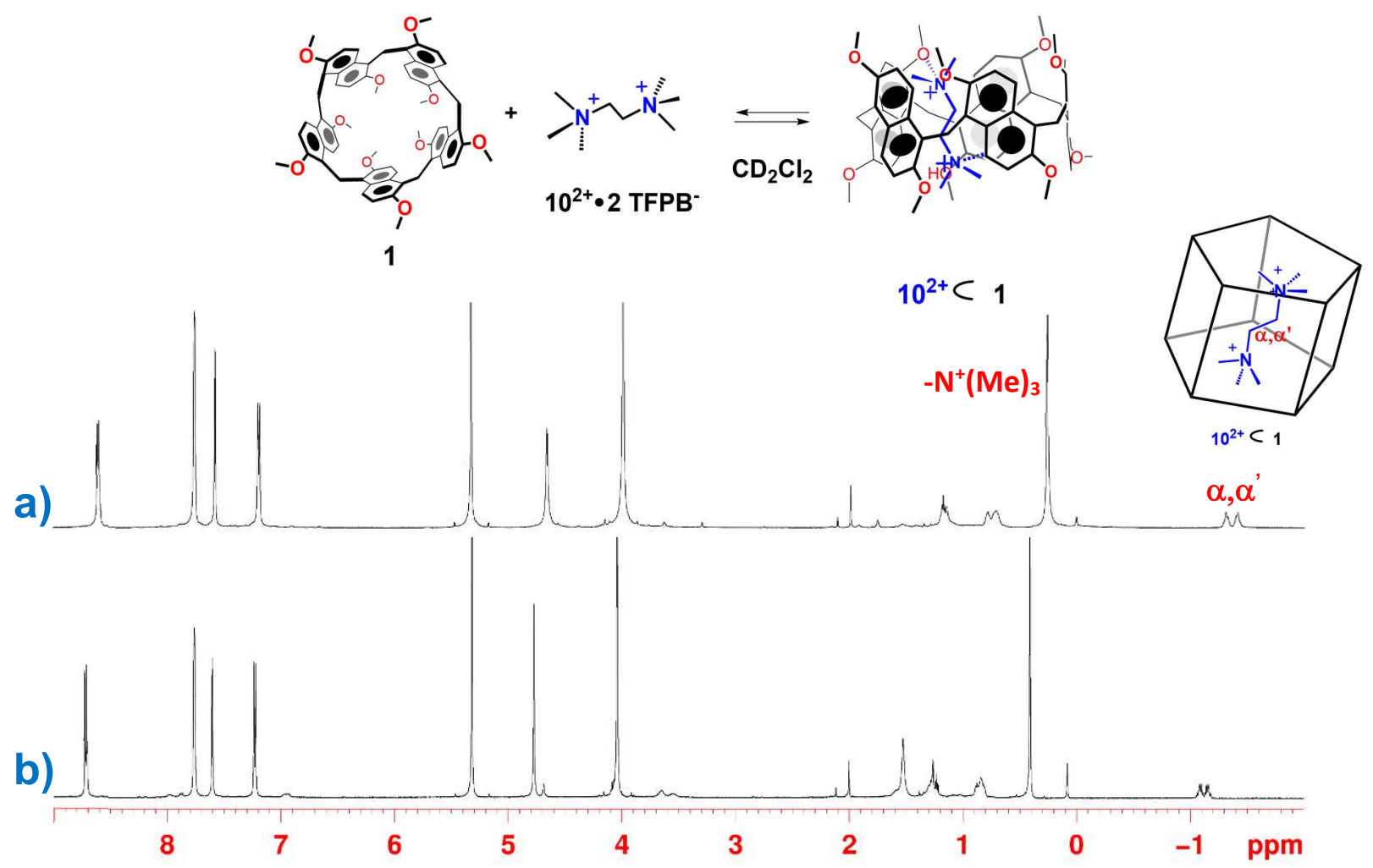

Figure S41: ${ }^{1} \mathrm{H}$ NMR spectra of an equimolar solution of $\mathbf{1}$ and $\mathbf{1 0}^{\mathbf{2 +}} \cdot \mathbf{2} \mathbf{T F P B}^{-}$(a) at $183 \mathrm{~K}$ and (b) at $298 \mathrm{~K}\left(600 \mathrm{MHz}, \mathrm{CD}_{2} \mathrm{Cl}_{2}\right)$. 


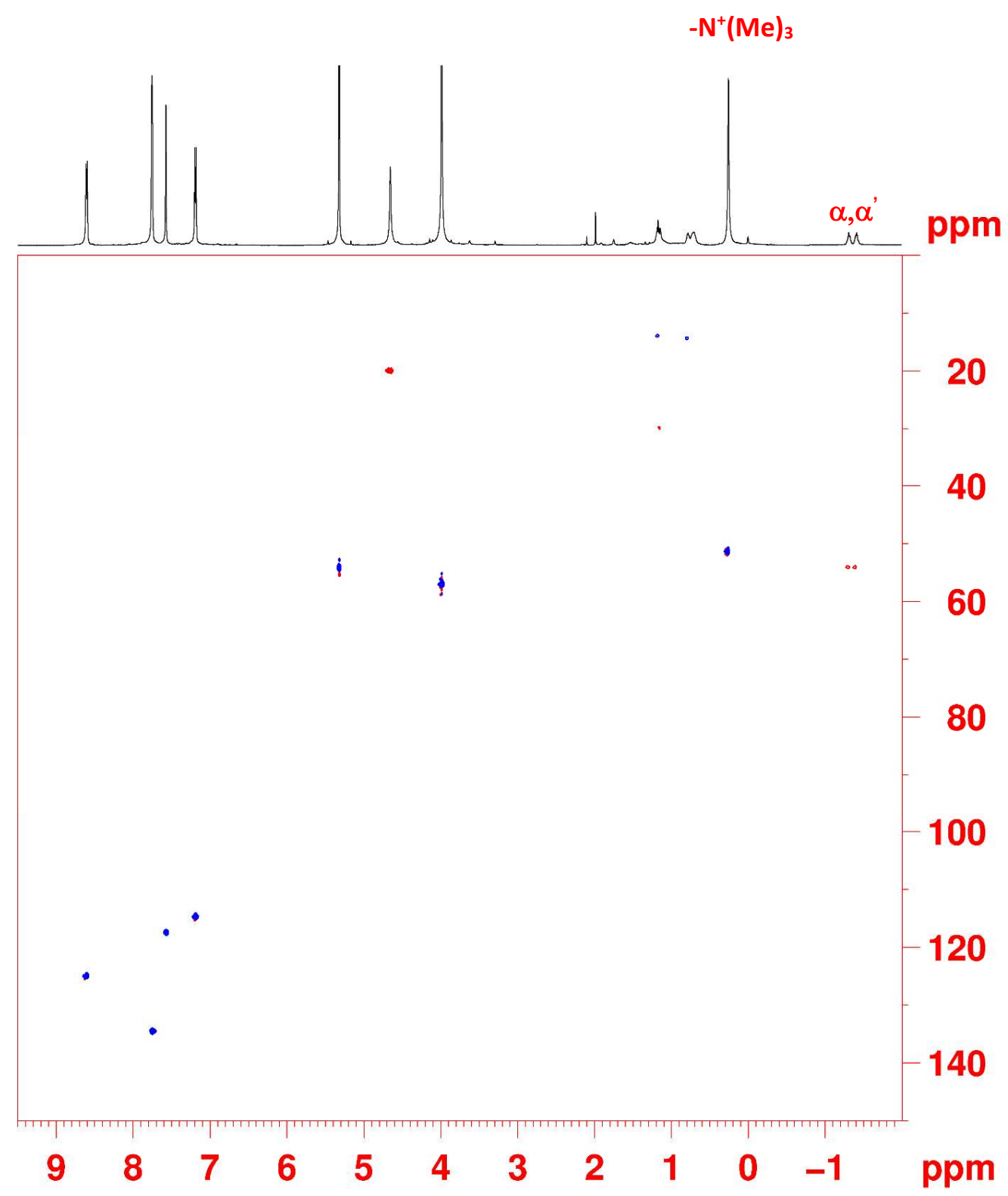

Figure S42: 2D-DQF COSY spectrum of $\mathbf{1 0}^{\mathbf{2}} \subset \mathbf{1}\left(\mathrm{CD}_{2} \mathrm{Cl}_{2}, 600 \mathrm{MHz}, 183 \mathrm{~K}\right)$. 
Copies of NMR and HR Mass Spectra of $9^{2+} \subset 1$
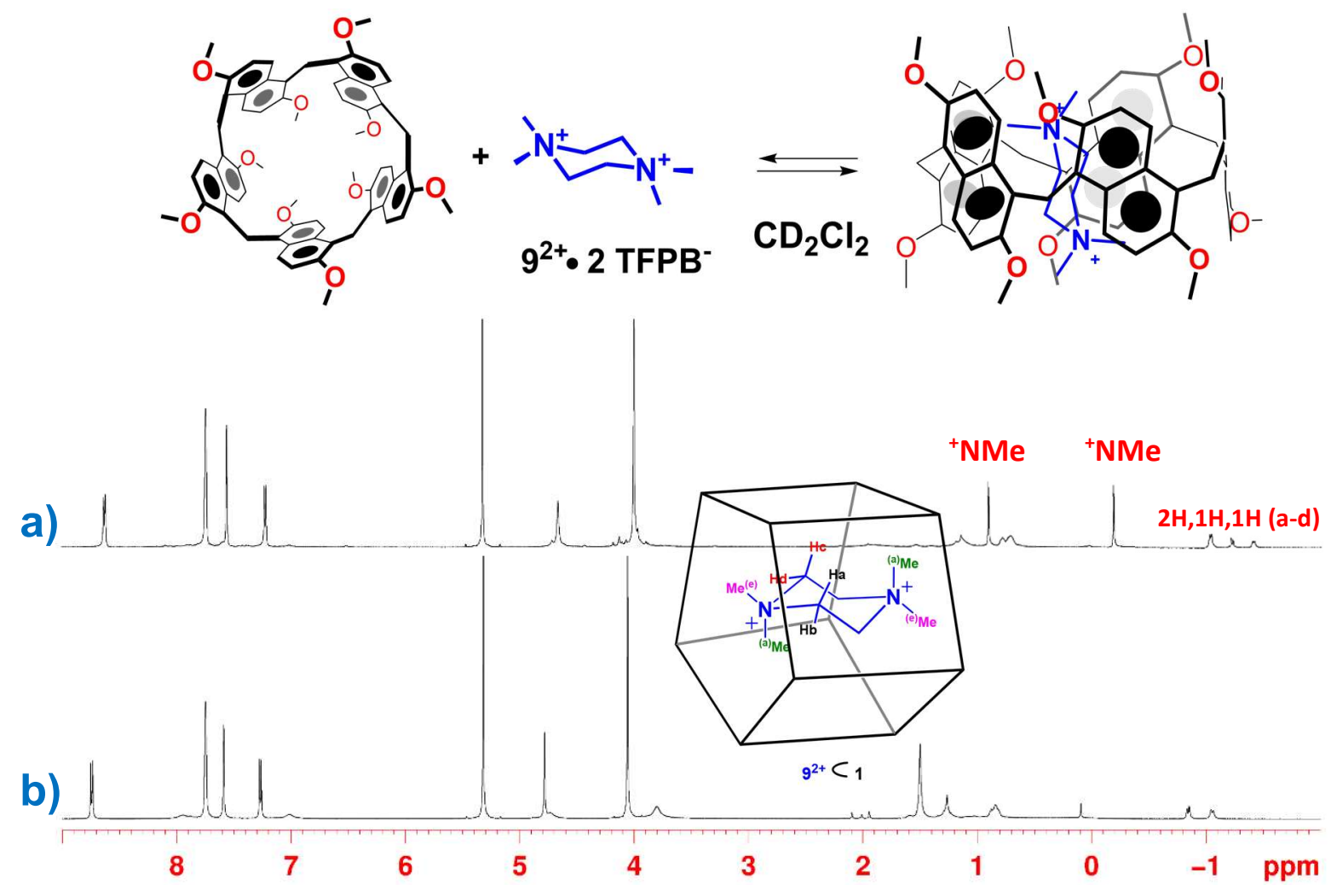

Figure S43: ${ }^{1} \mathrm{H}$ NMR spectra of an equimolar solution of $\mathbf{1}$ and $\mathbf{9}^{2+} \cdot \mathbf{2}$ TFPB $^{-}$(a) at $183 \mathrm{~K}$ and (b) at $298 \mathrm{~K}\left(600 \mathrm{MHz}, \mathrm{CD}_{2} \mathrm{Cl}_{2}\right)$. 


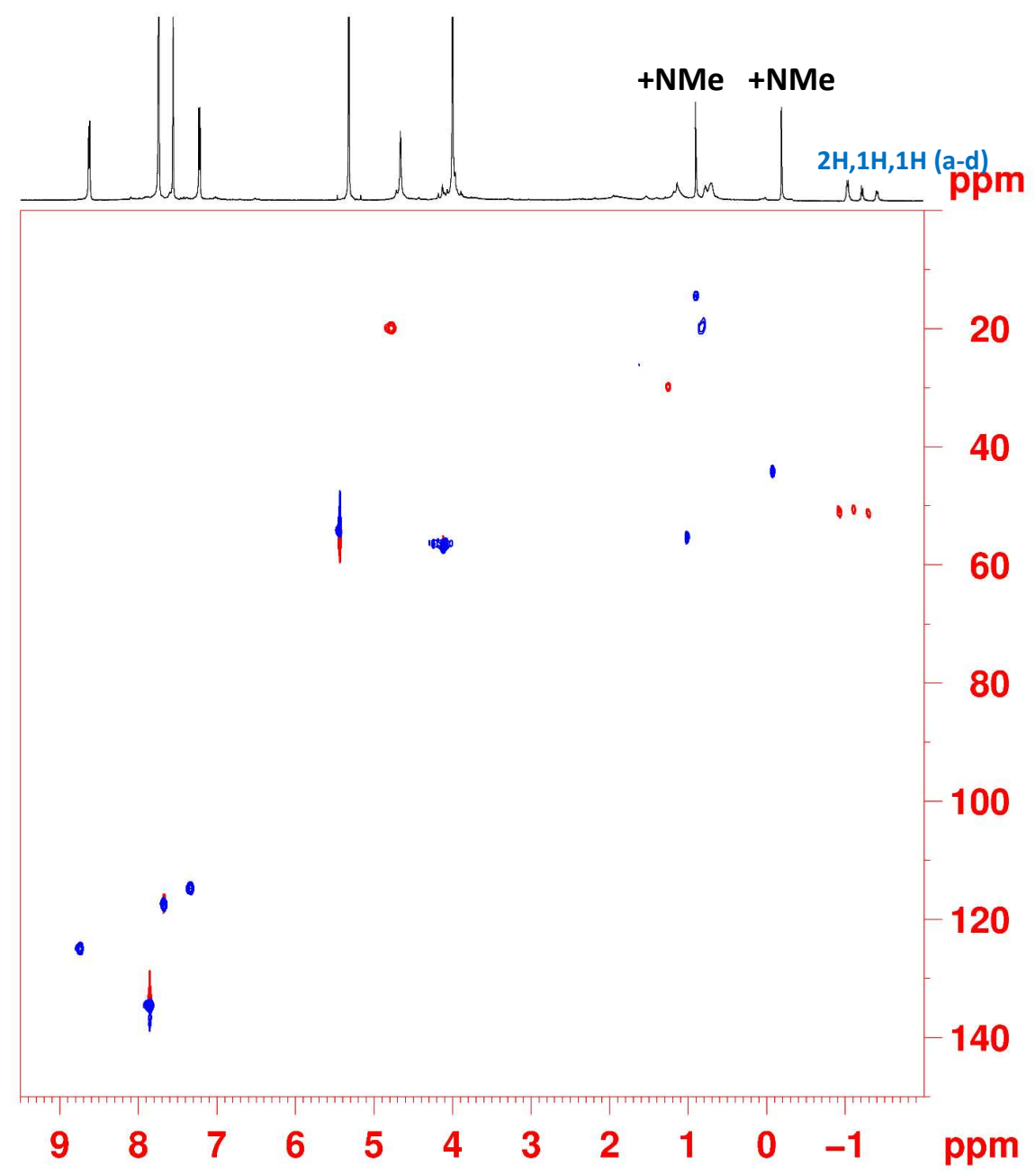

Figure S44: 2D-HSQC spectrum of $9^{2+} \subset \mathbf{1}\left(\mathrm{CD}_{2} \mathrm{Cl}_{2}, 600 \mathrm{MHz}, 183 \mathrm{~K}\right)$. 


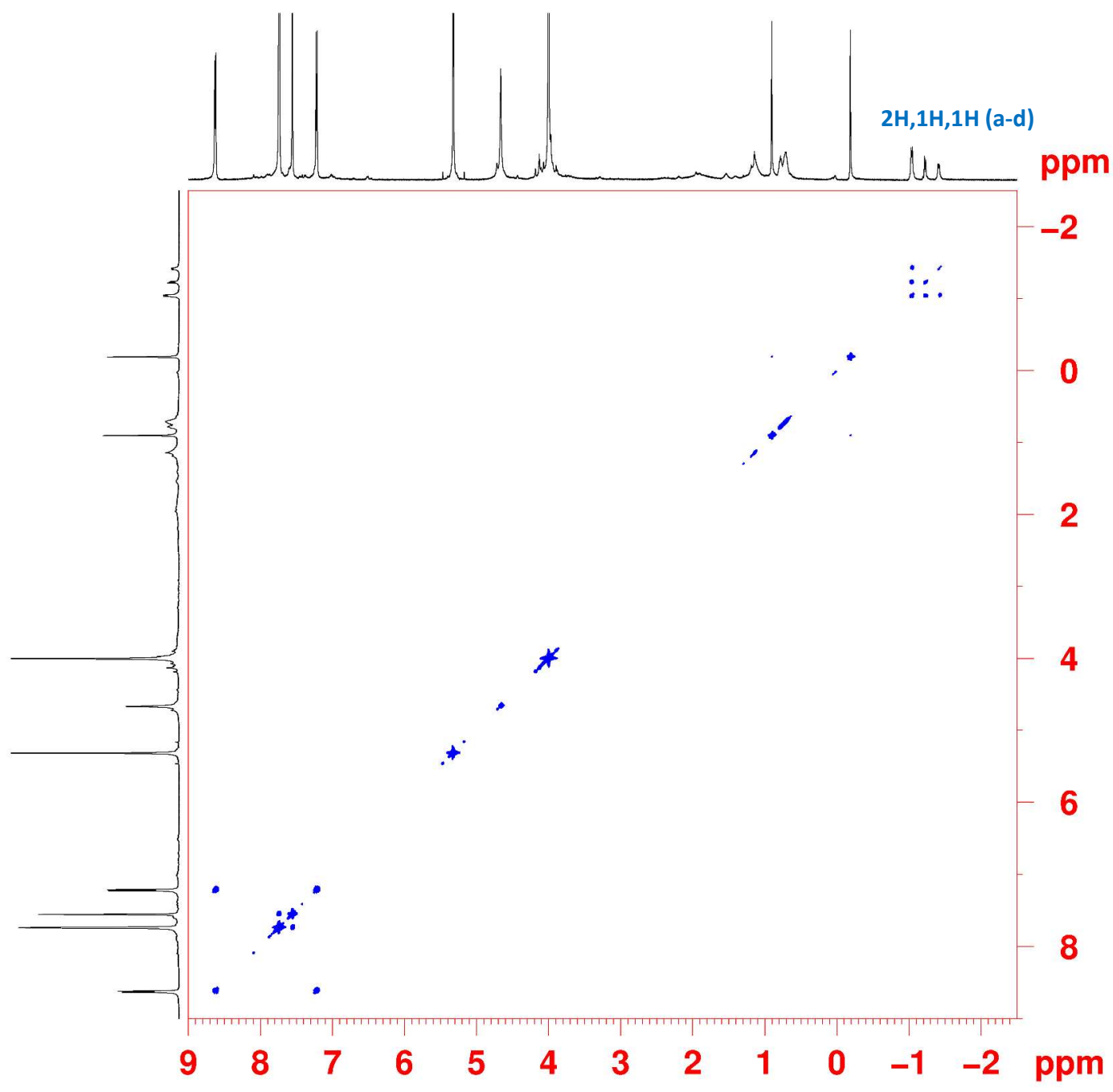

Figure S45: 2D-DQF COSY spectrum of $\mathbf{9}^{2+} \subset \mathbf{1}\left(\mathrm{CD}_{2} \mathrm{Cl}_{2}, 600 \mathrm{MHz}, 183 \mathrm{~K}\right)$. 
Copies of NMR and HR Mass Spectra of $5^{+} \subset 2$
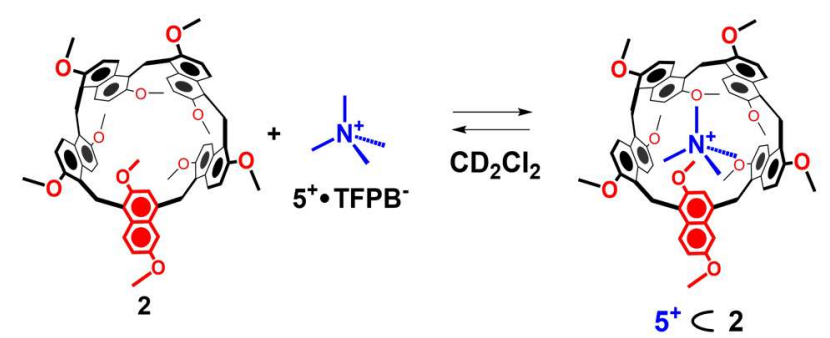

a)

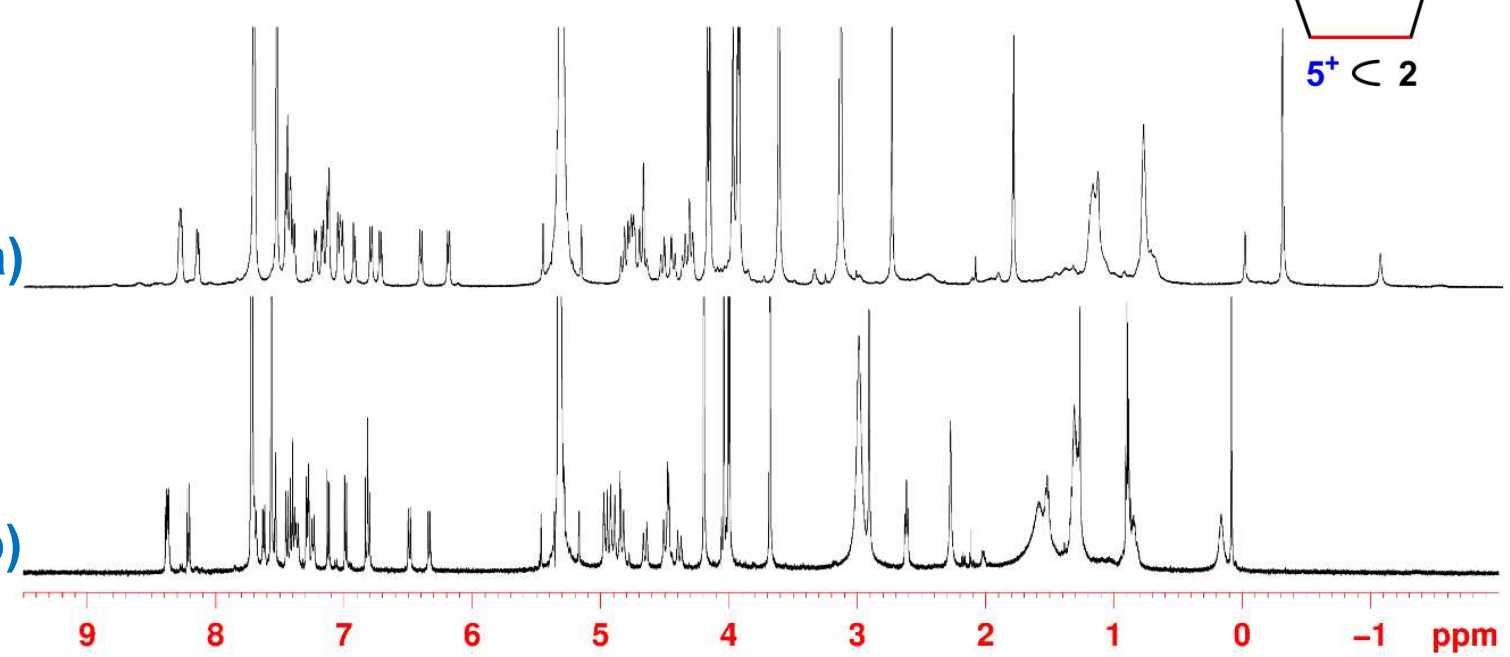

Figure S46: ${ }^{1} \mathrm{H}$ NMR spectra of an equimolar solution of $\mathbf{2}$ and $\mathbf{5}^{+}$(a) at $183 \mathrm{~K}$ and (b) at $298 \mathrm{~K}$ $\left(600 \mathrm{MHz}, \mathrm{CD}_{2} \mathrm{Cl}_{2}\right)$.

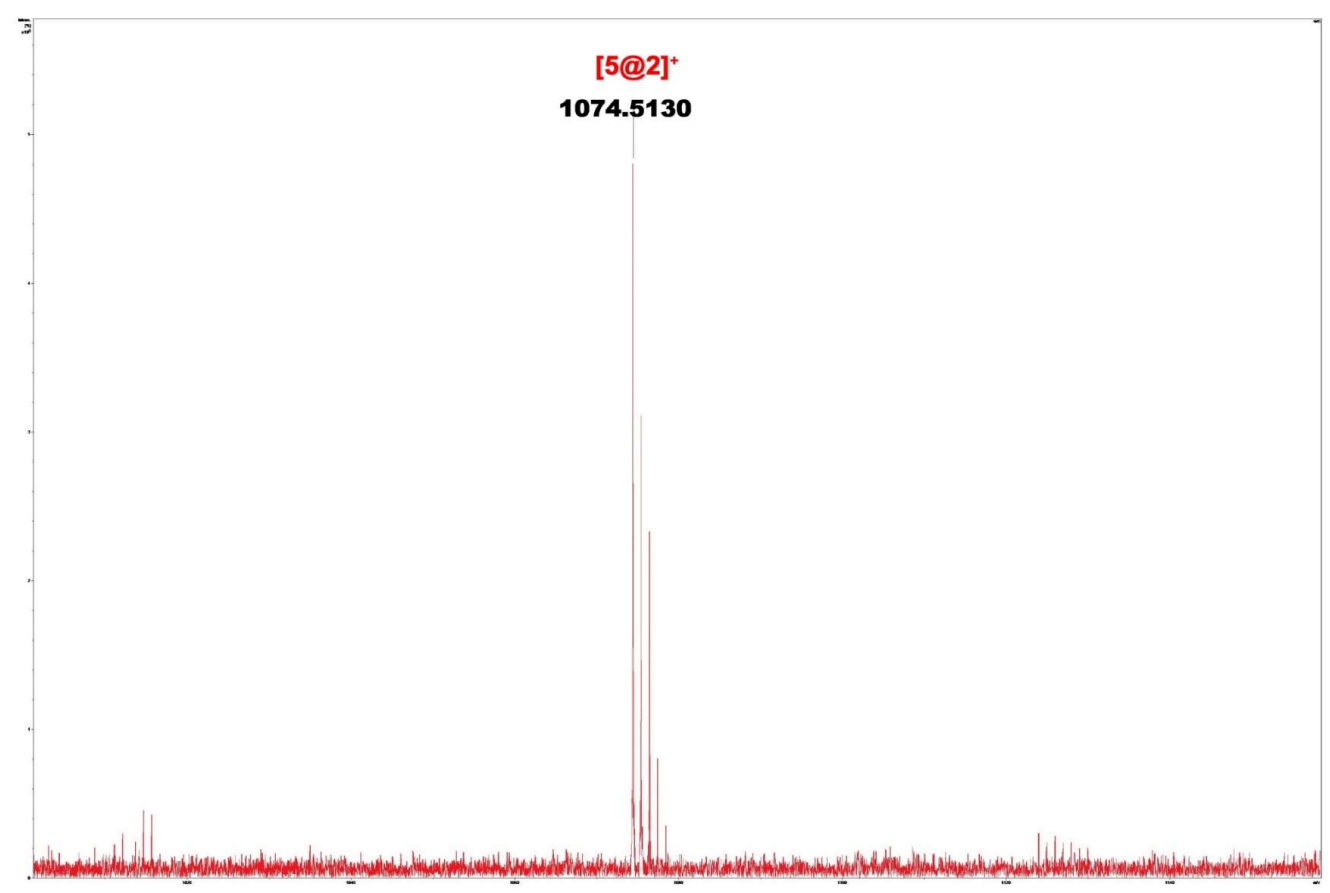

Figure S47: Significant portion of the HR ESI FT-ICR mass spectrum of $[5 \subset 2]^{+}$. 
Copies of NMR and HR Mass Spectra of $7^{+} \subset 2$

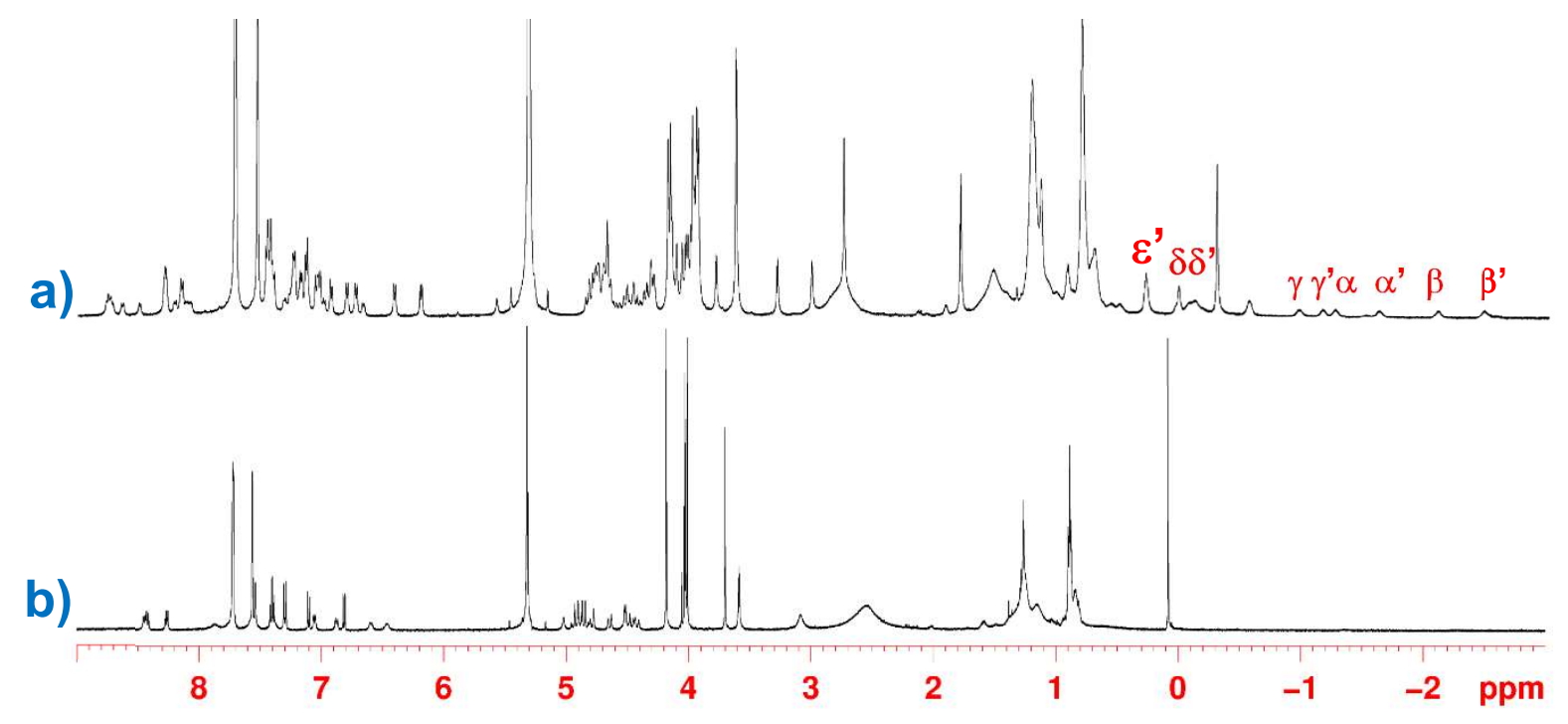

Figure S48: ${ }^{1} \mathrm{H}$ NMR spectra spectrum of an equimolar solution of 2 and $\mathbf{7}^{+}$(a) at $183 \mathrm{~K}$ and (b) at $298 \mathrm{~K}\left(600 \mathrm{MHz}, \mathrm{CD}_{2} \mathrm{Cl}_{2}\right)$. 


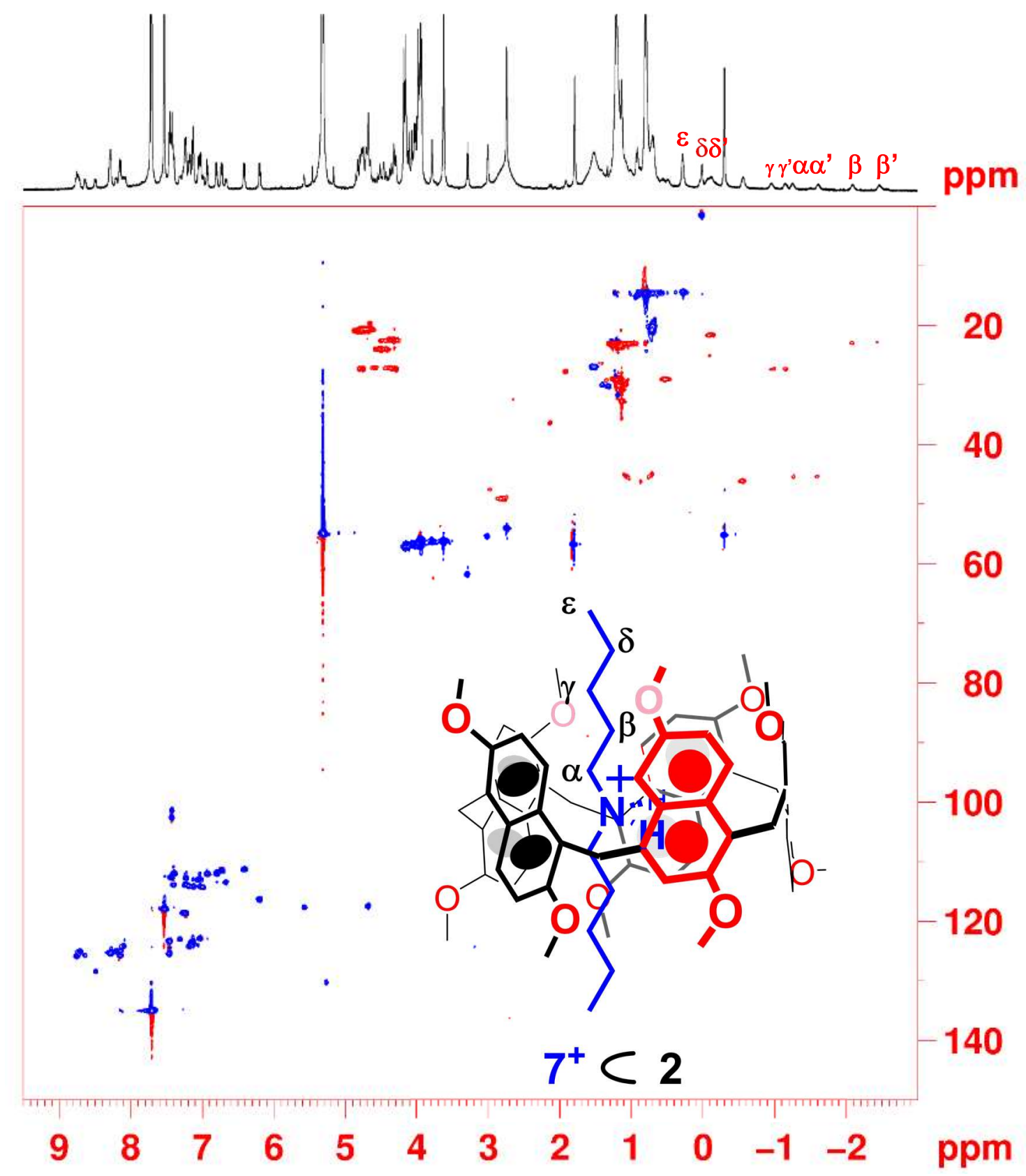

Figure S49: 2D-HSQC spectrum of $7^{+} \subset 2\left(\mathrm{CD}_{2} \mathrm{Cl}_{2}, 600 \mathrm{MHz}, 183 \mathrm{~K}\right)$. 


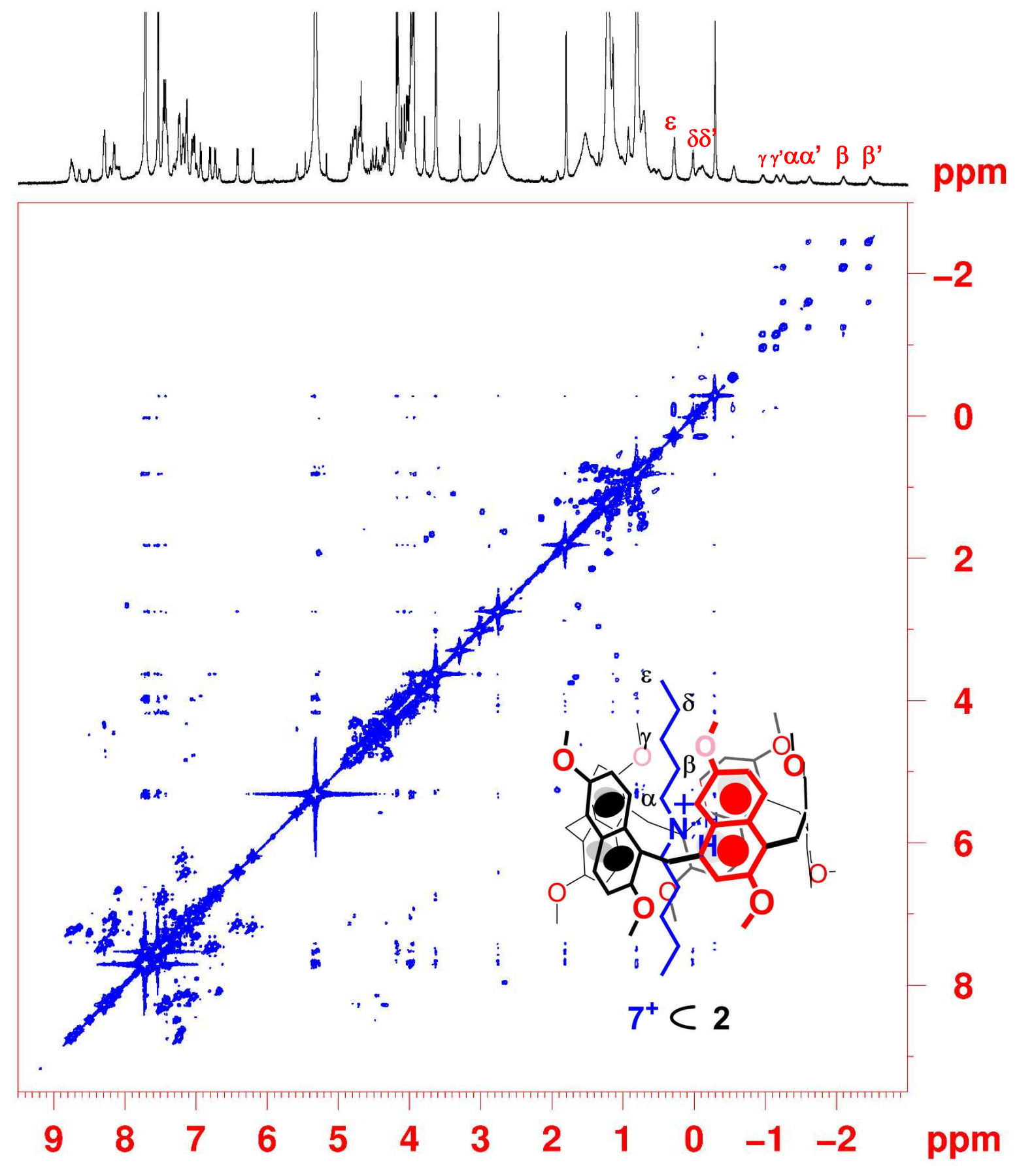

Figure S50: 2D-DQF COSY spectrum of $7^{+} \subset \mathbf{2}\left(\mathrm{CD}_{2} \mathrm{Cl}_{2}, 600 \mathrm{MHz}, 183 \mathrm{~K}\right)$. 


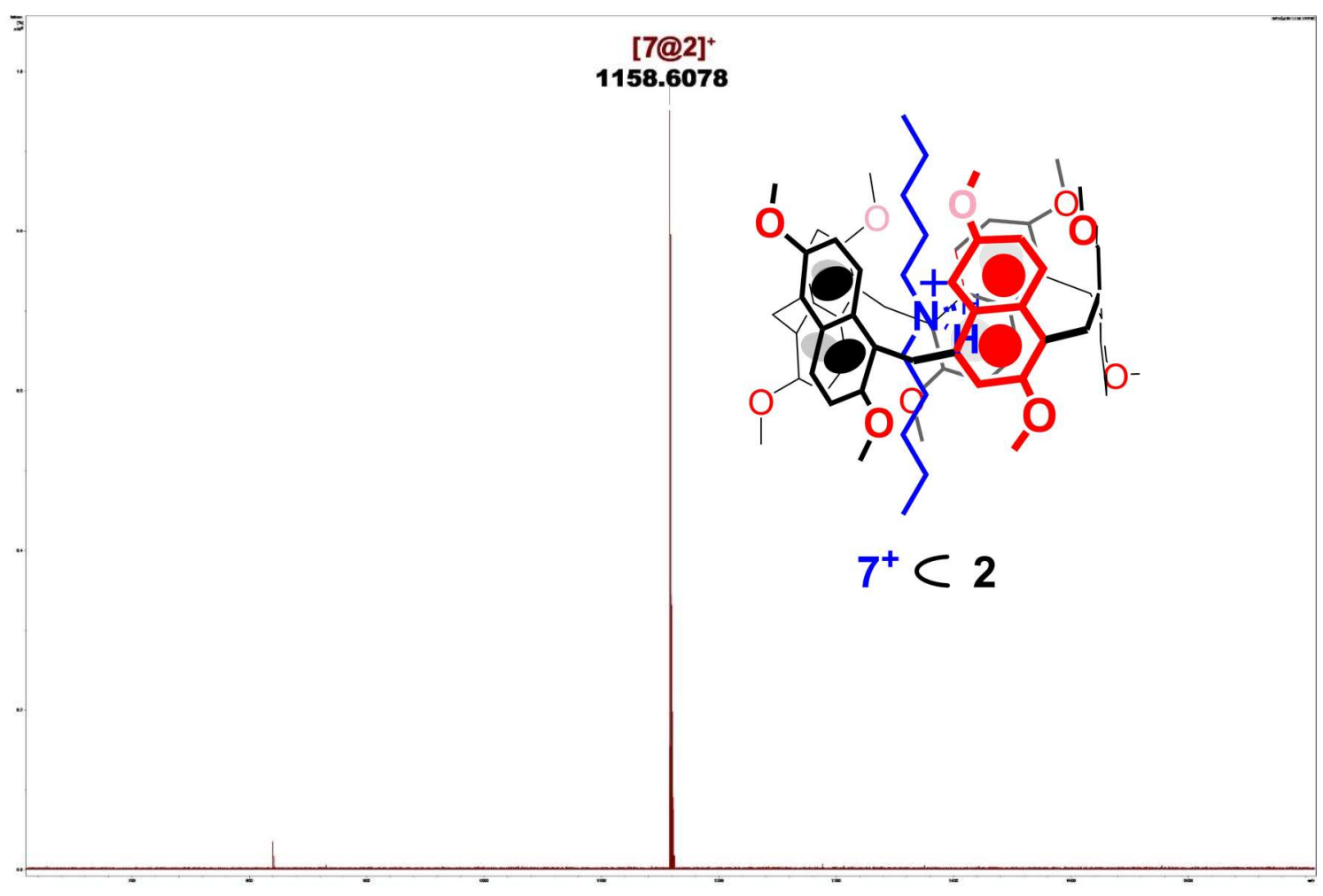

Figure S51: Significant portion of the HR ESI FT-ICR mass spectrum of $[7 \subset 2]^{+}$. 


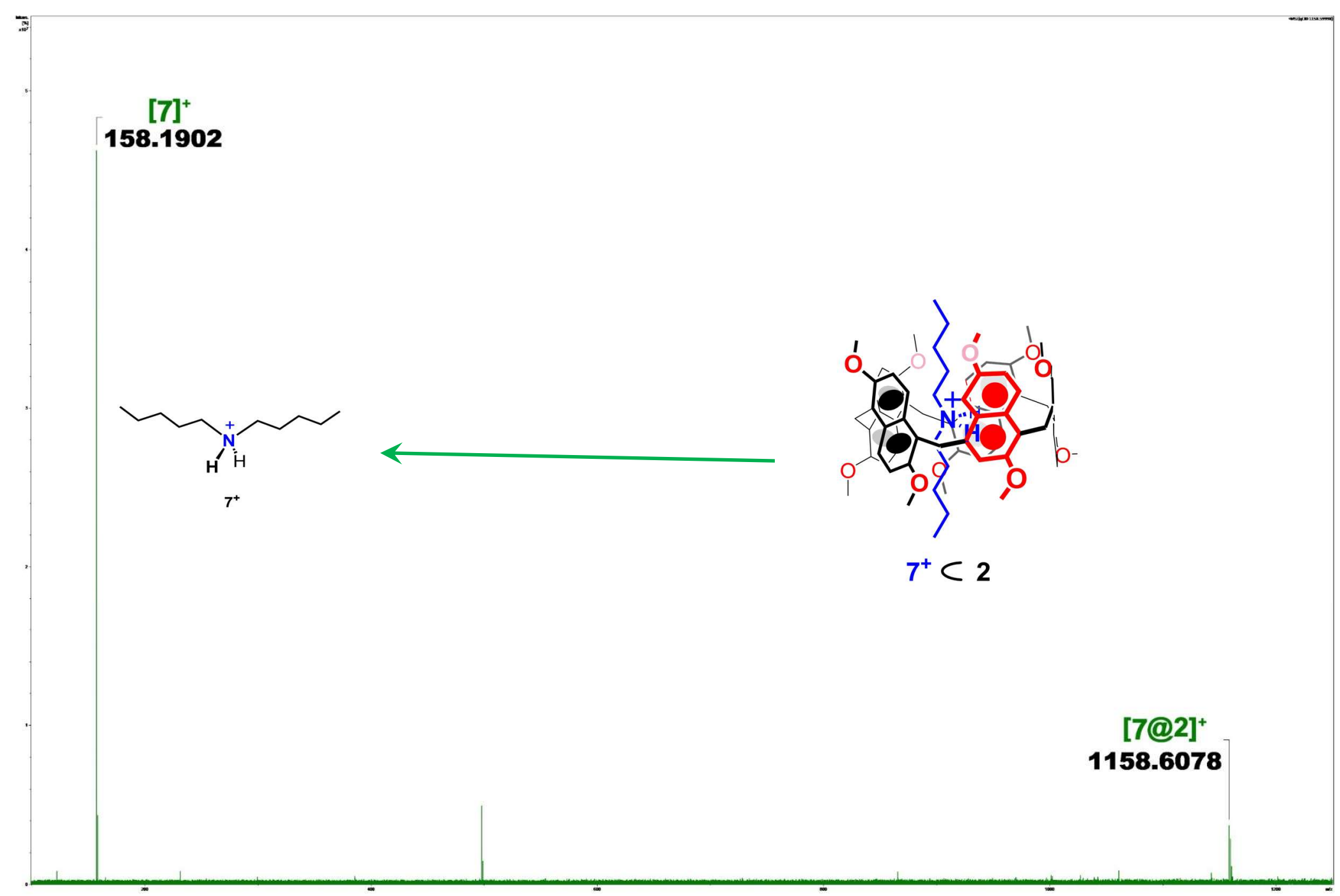

Figure S52: HR ESI-FT-ICR-CID mass spectrum of $[7 \subset 2]^{+}$ 
Copies of NMR and HR Mass Spectra of $6^{+} \subset 3$

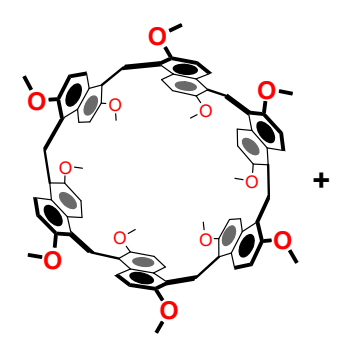

3

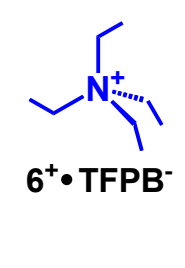

$\mathrm{CD}_{2} \mathrm{Cl}_{2}$
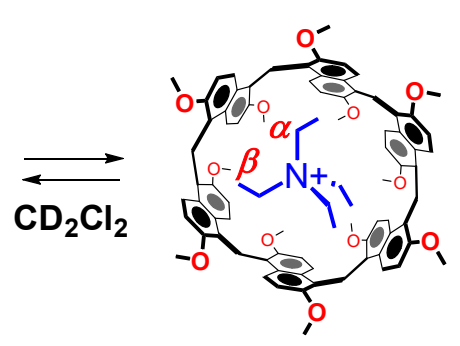

$6^{+}<3$

a)

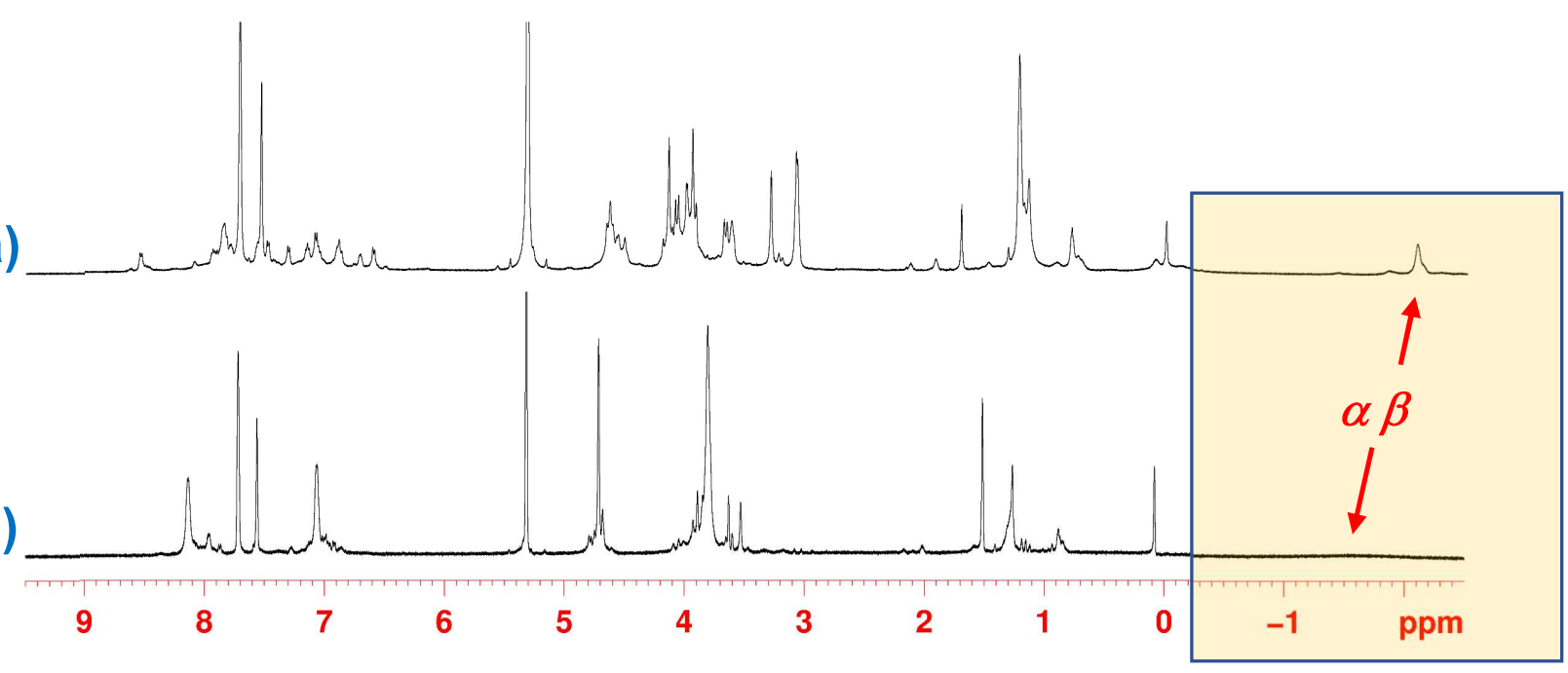

Figure S53: ${ }^{1} \mathrm{H}$ NMR spectra of an equimolar solution of $\mathbf{3}$ and $\mathbf{6}^{+} \cdot$ TFPB- $^{-}$(a) at $183 \mathrm{~K}$ and (b) at $298 \mathrm{~K}\left(600 \mathrm{MHz}, \mathrm{CD}_{2} \mathrm{Cl}_{2}\right)$.

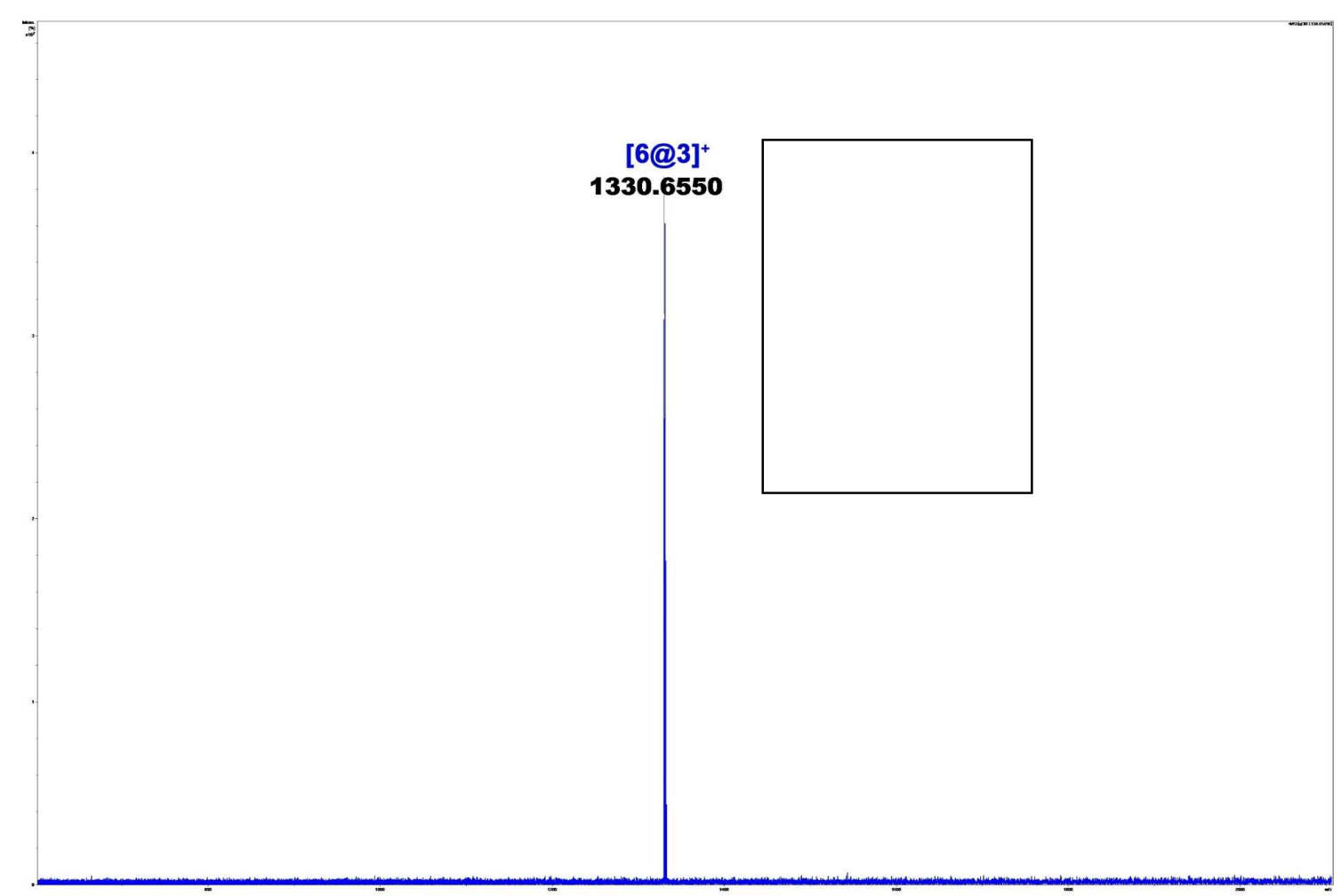

Figure S54: Significant portion of the HR ESI FT-ICR mass spectrum of $[\mathbf{6} \subset \mathbf{3}]^{+}$. 


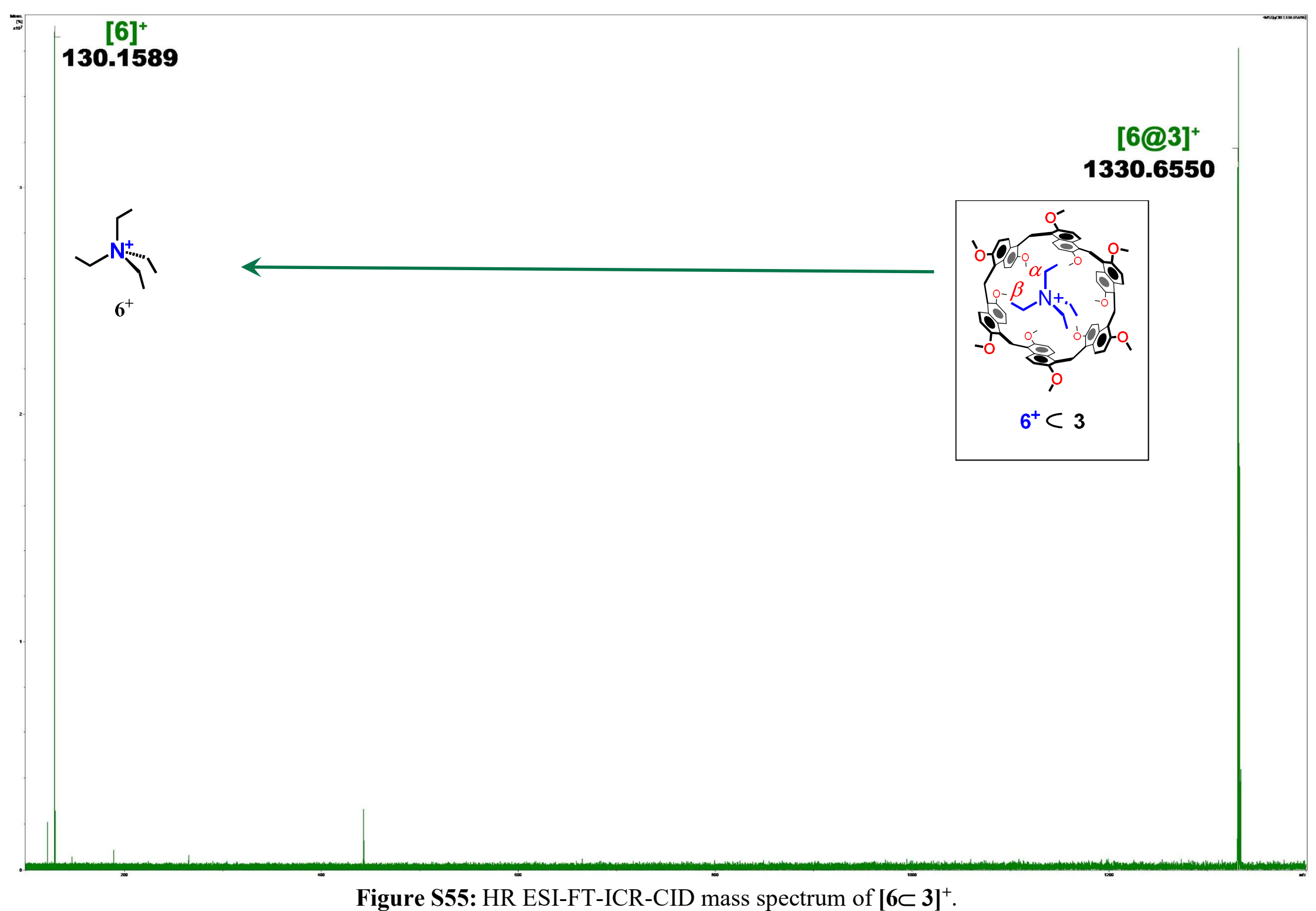




\section{Copies of HR Mass Spectra of prismarenes complexes}

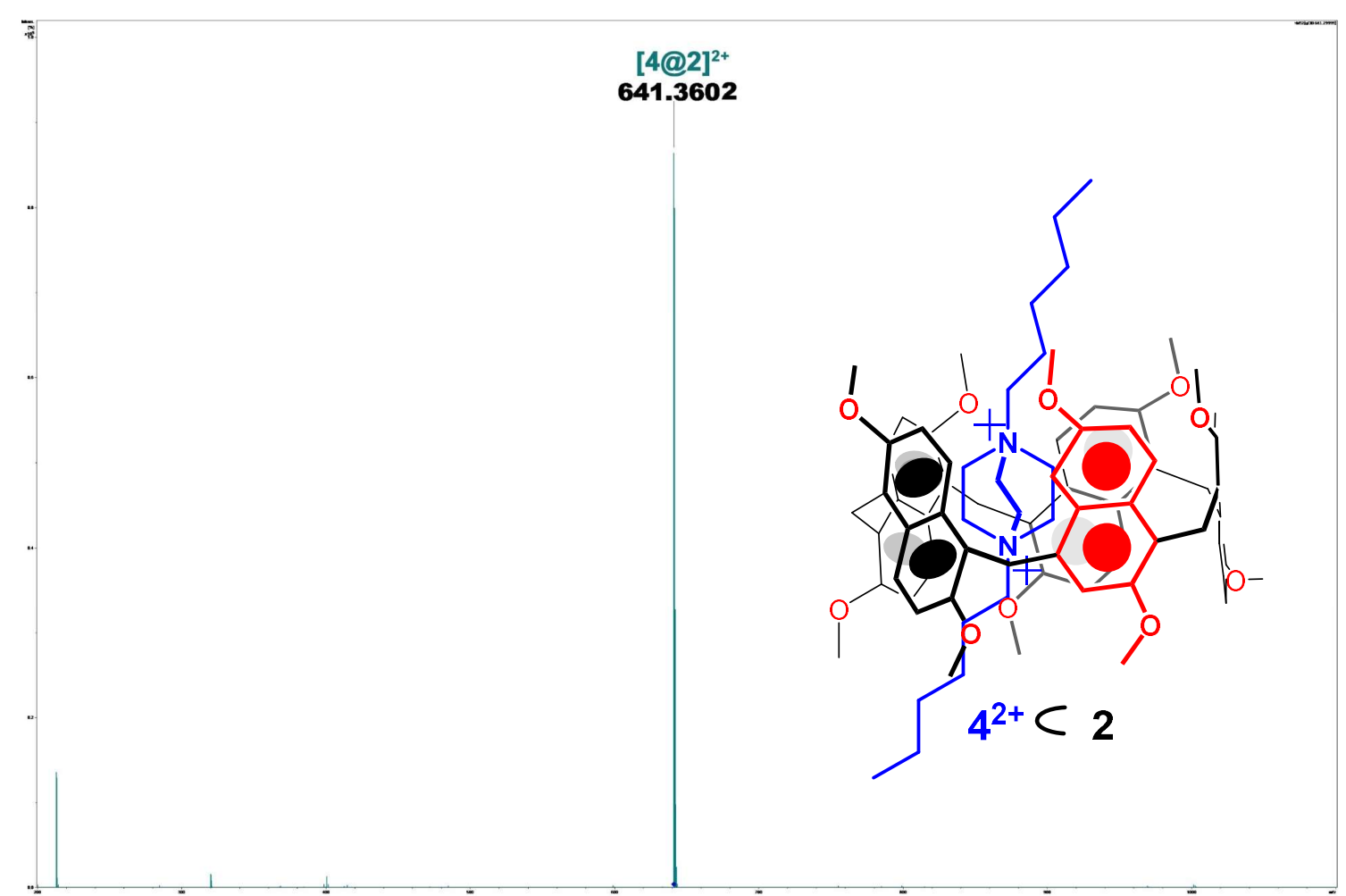

Figure S56: Significant portion of the HR ESI FT-ICR mass spectrum of $[4 \subset 2]^{2+}$. 


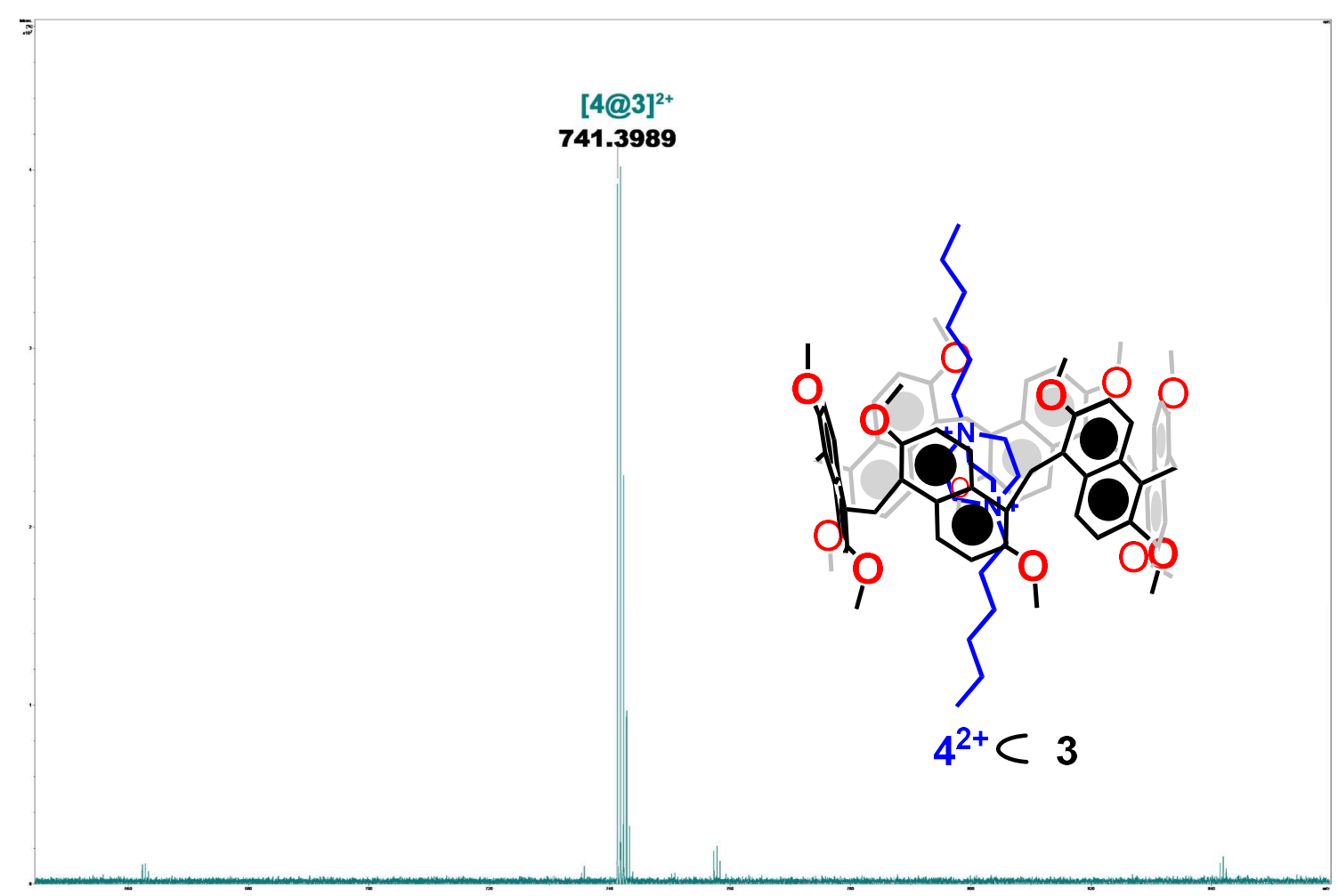

Figure S57: Significant portion of the HR ESI FT-ICR mass spectrum of $[4 \subset 3]^{2+}$. 


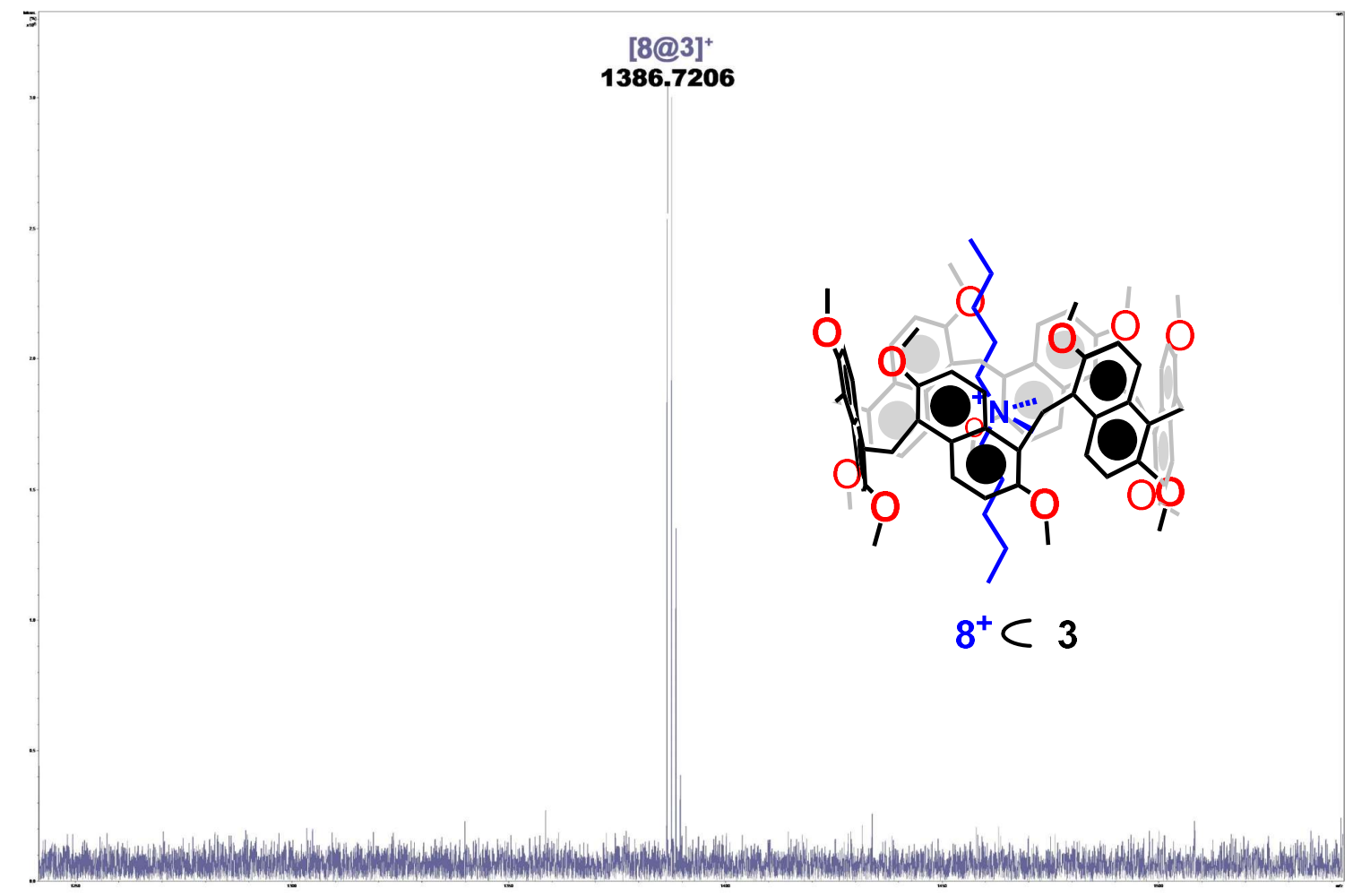

Figure S58: Significant portion of the HR ESI FT-ICR mass spectrum of $[\mathbf{8} \subset \mathbf{3}]^{+}$. 


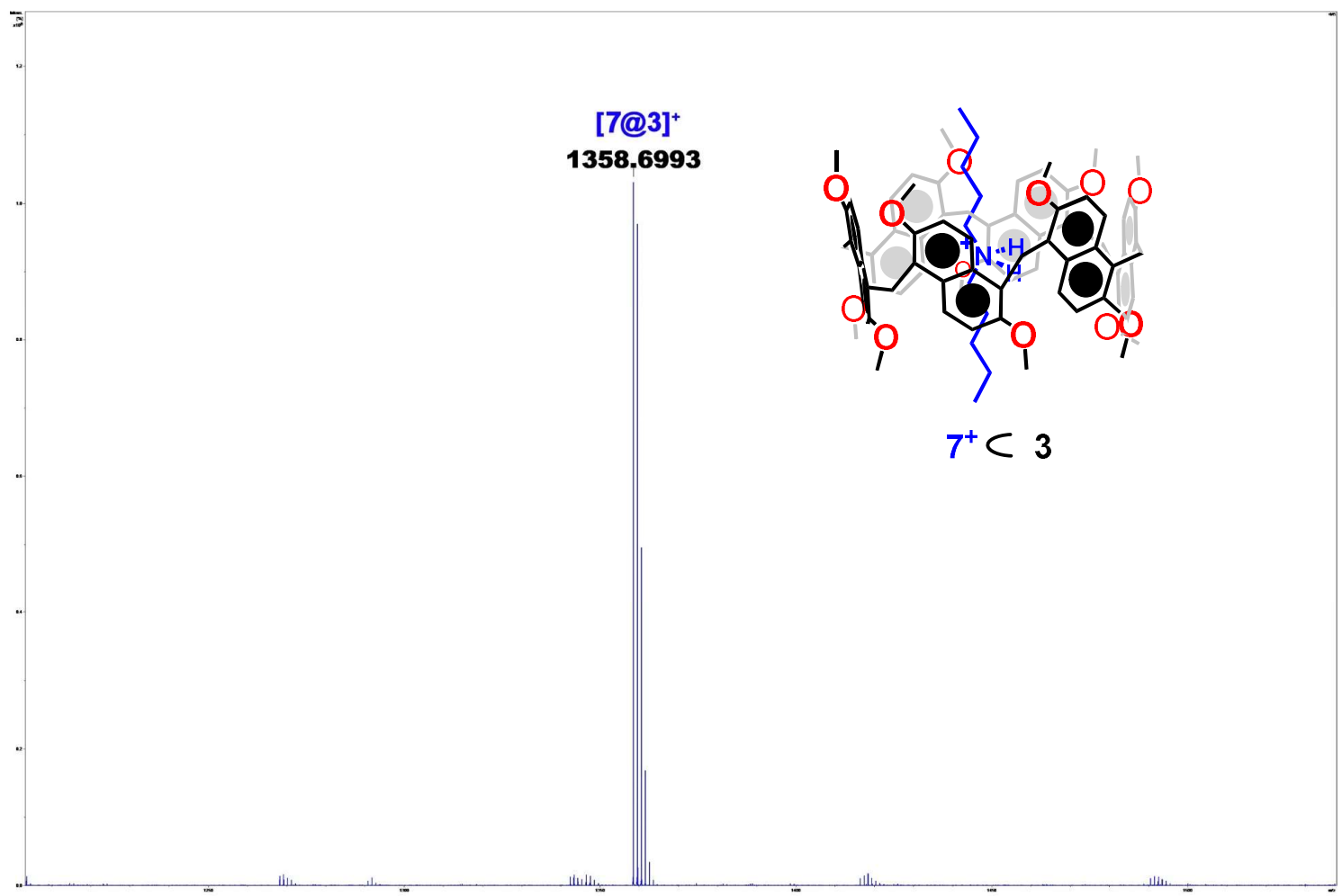

Figure S59: Significant portion of the HR ESI FT-ICR mass spectrum of $[7 \subset 3]^{+}$. 


\section{${ }^{1} \mathrm{H}$ NMR determination of $K_{\text {ass }}$ values. ${ }^{3}$}

The association constant values of complexes were calculated by means of three methods:

a) Integration of free and complexed ${ }^{1} \mathrm{H}$ NMR signals of host or guest. In this case, an equimolar solution $(2.85 \mathrm{mM})$ of hosts and guests was solubilized in $\mathrm{CD}_{2} \mathrm{Cl}_{2}$ and equilibrated in a NMR tube after mixing for $24 \mathrm{~h}$ at $40{ }^{\circ} \mathrm{C}$.

b) ${ }^{1} \mathrm{H}$ NMR competition experiments. In this case, was performed an analysis of a 1:1:1 mixture of host, and two guests in an NMR tube using $0.7 \mathrm{~mL}$ of $\mathrm{CD}_{2} \mathrm{Cl}_{2}$ as solvent.

c) Quantitative ${ }^{1} \mathrm{H}$ NMR experiments using TCE as the internal standard ${ }^{4}$. In this case, ${ }^{1} \mathrm{H}$ NMR experiments were carried out on a 1:1 mixture of host and guest in $0.7 \mathrm{~mL}$ of $\mathrm{CD}_{2} \mathrm{Cl}_{2}$ containing $1 \mu \mathrm{L}$ or $0.5 \mu \mathrm{L}$ of 1,1,2,2-tetrachloroethane $(\mathrm{d}=1.59 \mathrm{~g} / \mathrm{mL})$ as internal standard.

Table S2. Association constant $\left(K_{\text {ass, }} \mathrm{M}^{-1}\right)$ values for the formation of the complexes between the ammonium $\mathbf{4}^{\mathbf{2}+}-\mathbf{1 2}^{+}$cations as $\mathrm{TFPB}^{-}$salts and the prism[n]arenes $\mathbf{1}-\mathbf{3}$. Determined by ${ }^{1} \mathrm{H} \mathrm{NMR}$ experiments in $\mathrm{CD}_{2} \mathrm{Cl}_{2}(600 \mathrm{MHz})$. Errors $<15 \%$ calculated as mean values of three measures.

\begin{tabular}{|c|c|c|c|}
\hline & 1 & 2 & 3 \\
\hline $4^{2+}$ & $3.9 \cdot 10^{7[d]}$ & $470^{[f]}$ & $50^{[f]}$ \\
\hline $5^{+}$ & $6.4 \cdot 10^{4[e]}$ & $20^{[f]}$ & - \\
\hline $6^{+}$ & $90^{[f]}$ & - & $2700^{[f]}$ \\
\hline $7^{+}$ & $9600^{[f]}$ & $190^{[f]}$ & $310^{[f]}$ \\
\hline $8^{+}$ & $2.0 \cdot 10^{4[f]}$ & - & $100^{[f]}$ \\
\hline $9^{2+}$ & $1.8 \cdot 10^{7[c]}$ & $1400^{[f]}$ & - \\
\hline $10^{2+}$ & $4.7 \cdot 10^{6[b]}$ & $400^{[f]}$ & - \\
\hline $11^{+}$ & $150^{[f]}$ & $100^{[f]}$ & $70^{[f]}$ \\
\hline $12^{+}$ & $4.6 \cdot 10^{4[a]}$ & $50^{[f]}$ & - \\
\hline
\end{tabular}

${ }^{[a]}$ Calculated by quantitative ${ }^{1} \mathrm{H}$ NMR spectroscopy at $298 \mathrm{~K}$ analysis using TCE as internal standard (Fig S64), the calculated $K_{\text {ass }}$ value was confirmed by competition experiment. ${ }^{[b]}$ Calculated by competition experiment at $298 \mathrm{~K}$ with $\mathbf{1 2}^{+}$(Fig S65). ${ }^{[\mathrm{c}]}$ Calculated by competition experiment at 298 $\mathrm{K}$ with $\mathbf{1 0}^{\mathbf{2}+}$ (Fig S66). ${ }^{[\mathrm{d}]}$ Calculated by competition experiment at $298 \mathrm{~K}$ with $\mathbf{9}^{2+}$ (Fig S67). ${ }^{[\mathrm{e}]}$ Calculated by quantitative ${ }^{1} \mathrm{H}$ NMR study at $183 \mathrm{~K}$ analysis using TCE as internal standard, the calculated $K_{\text {ass }}$ value was confirmed by competition experiment. ${ }^{[\mathrm{f}]}$ Calculated at $183 \mathrm{~K}$ by integration of ${ }^{1} \mathrm{H}$ NMR signals of free and complexed species. 


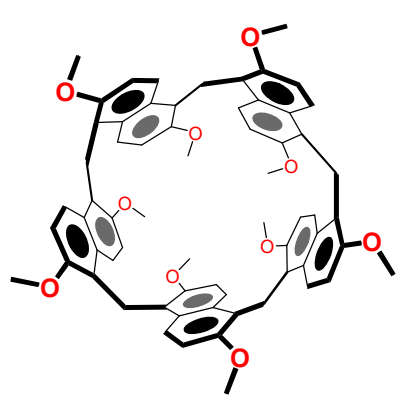

1

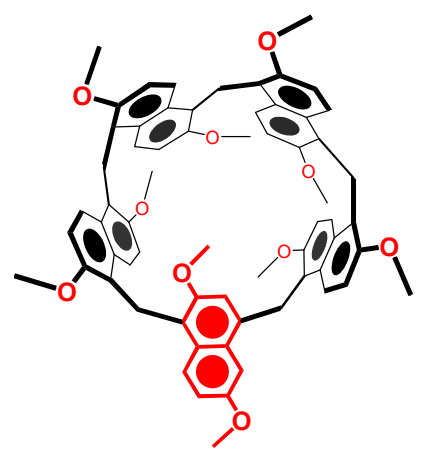

2

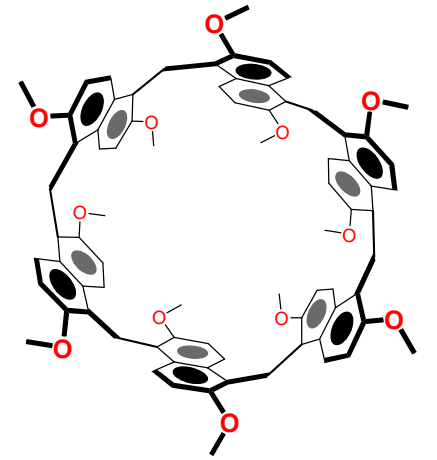

3

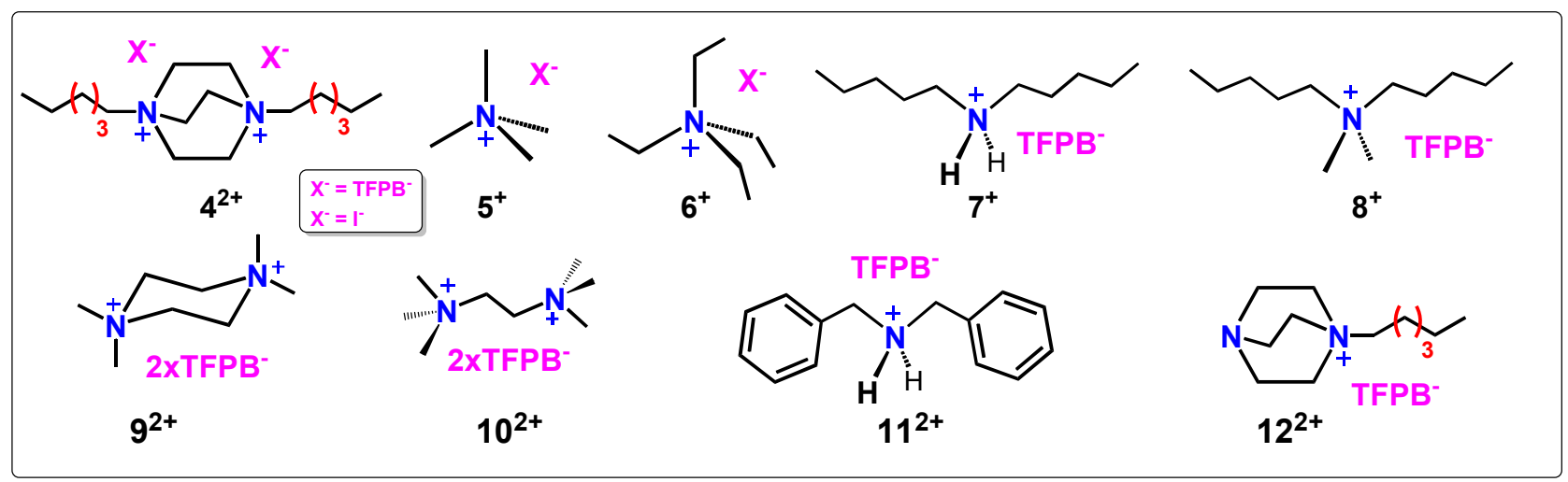




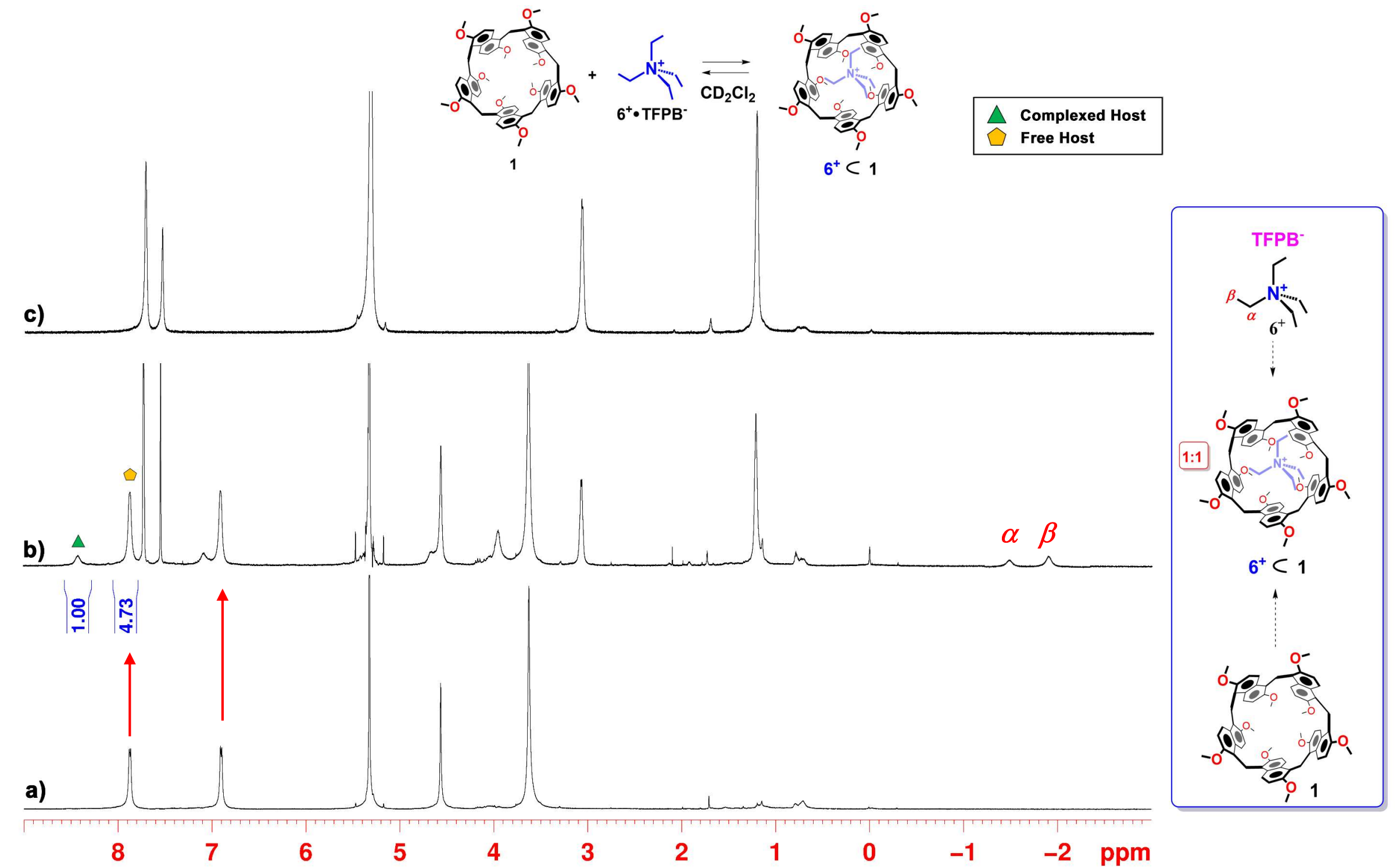

Figure S60: ${ }^{1} \mathrm{H}$ NMR spectra $\left(600 \mathrm{MHz}, \mathrm{CD}_{2} \mathrm{Cl}_{2}, 183 \mathrm{~K}\right)$ of: (a) a solution of $\mathbf{1}$ (b) an equimolar solution $(2.85 \mathrm{mM})$ of $\mathbf{1}$ and $\mathbf{6}^{+} \cdot \mathbf{T F P B}^{-}$in $0.7 \mathrm{~mL}$ of $\mathrm{CD}_{2} \mathrm{Cl}_{2}$ and (c) a solution of $\mathbf{6}^{+}$TFPB $^{-}$. 


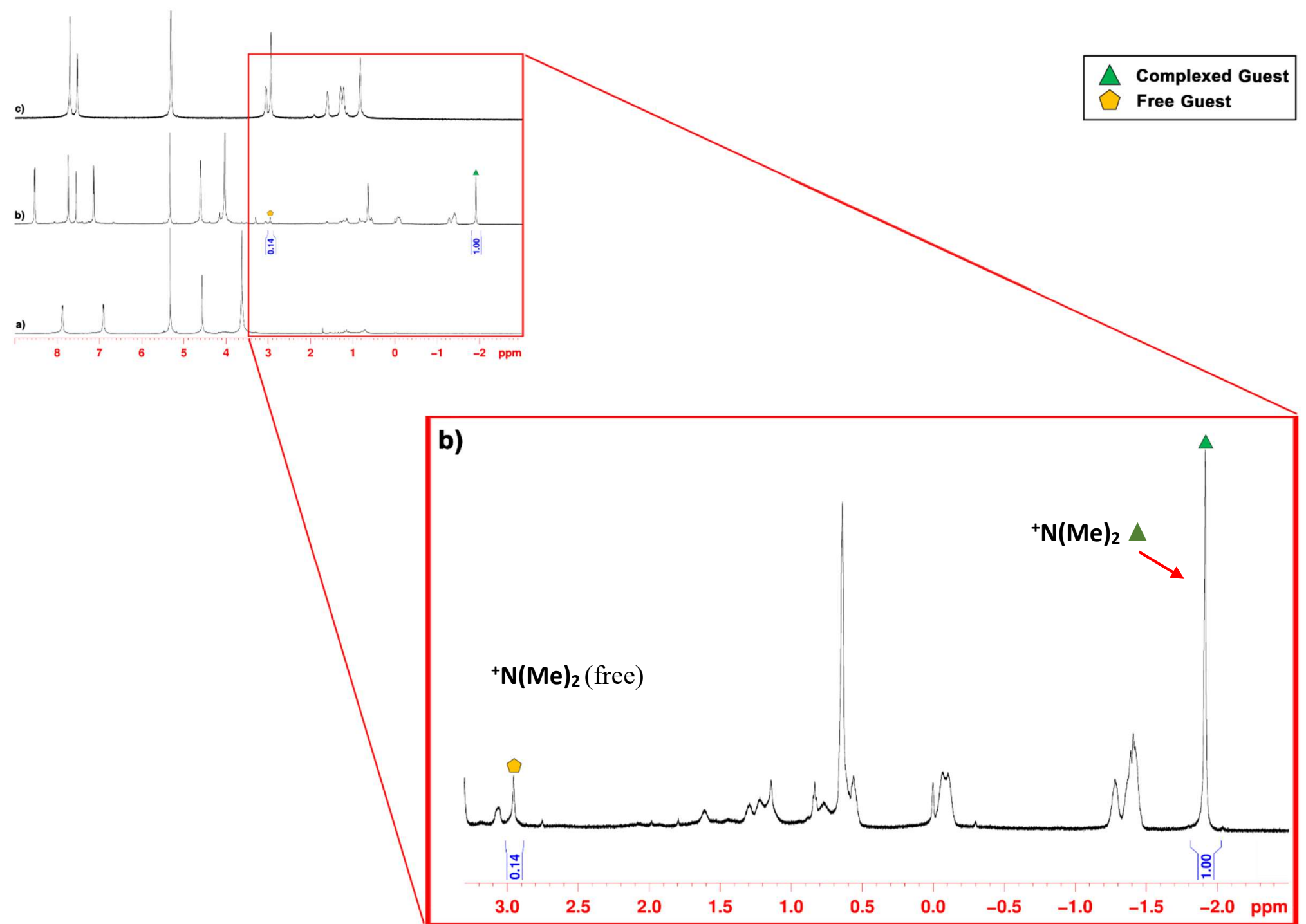

Figure S61: ${ }^{1} \mathrm{H}$ NMR spectra $\left(600 \mathrm{MHz}, \mathrm{CD}_{2} \mathrm{Cl}_{2}, 183 \mathrm{~K}\right)$ of: (a) a solution of $\mathbf{1}$ (b) an equimolar solution $(2.85 \mathrm{mM})$ of $\mathbf{1}$ and $\mathbf{8}^{+} \cdot \mathbf{T F P B}^{-}$in $0.7 \mathrm{~mL}$ of $\mathrm{CD}_{2} \mathrm{Cl}_{2}$ and (c) a solution of $\mathbf{8}^{+} \cdot \mathbf{T F P B}^{-}$. 


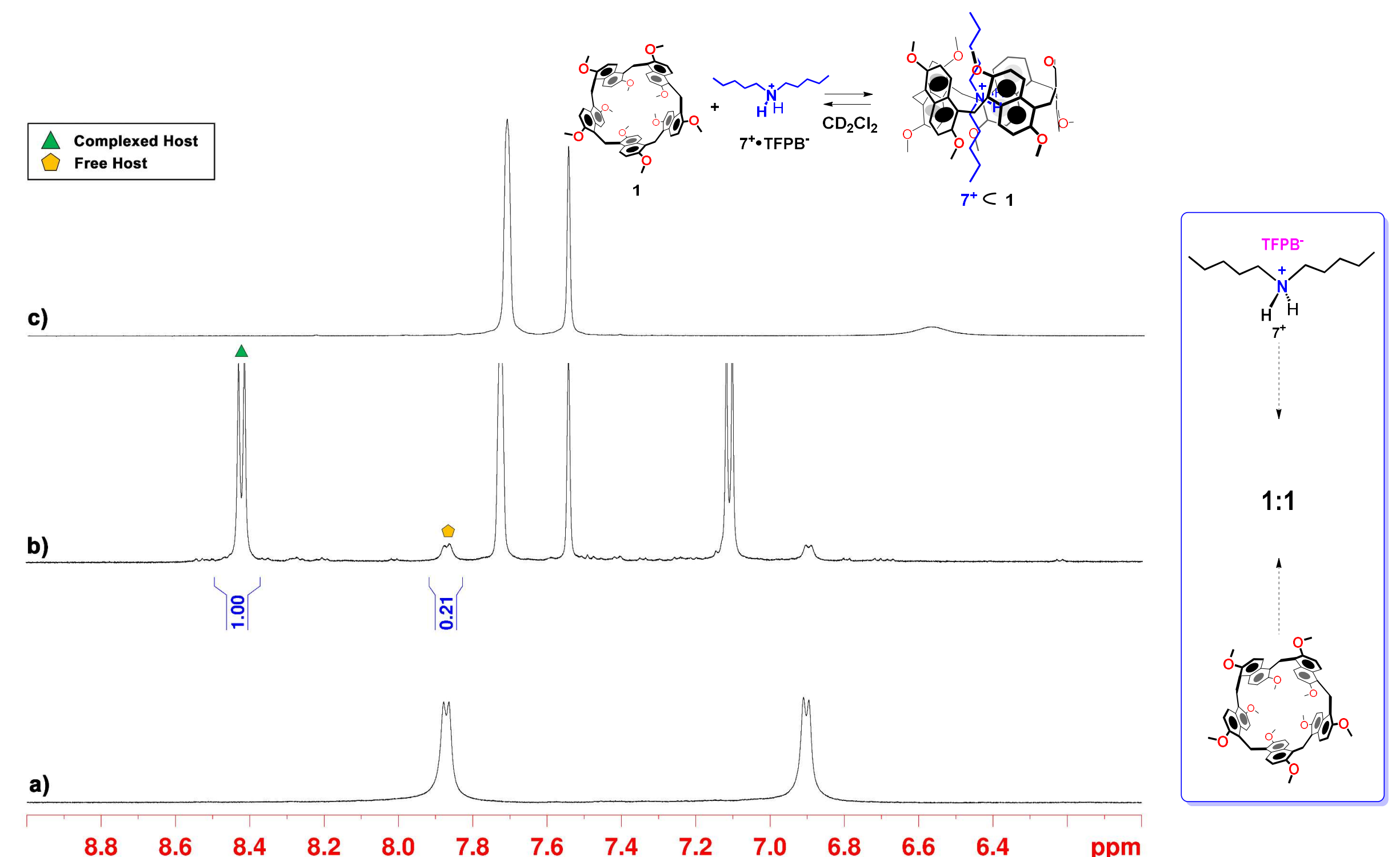

Figure S62: Significant portion of the ${ }^{1} \mathrm{H}$ NMR spectra $\left(600 \mathrm{MHz}, \mathrm{CD}_{2} \mathrm{Cl}_{2}, 183 \mathrm{~K}\right)$ of: (a) a solution of $\mathbf{1}$ (b) an equimolar solution (2.85 mM) of $\mathbf{1}$ and $7^{+} \cdot \mathbf{T F P B}^{-}$in $0.7 \mathrm{~mL}$ of $\mathrm{CD}_{2} \mathrm{Cl}_{2}$ and (c) a solution of $7^{+} \cdot \mathbf{T F P B}^{-}$. 


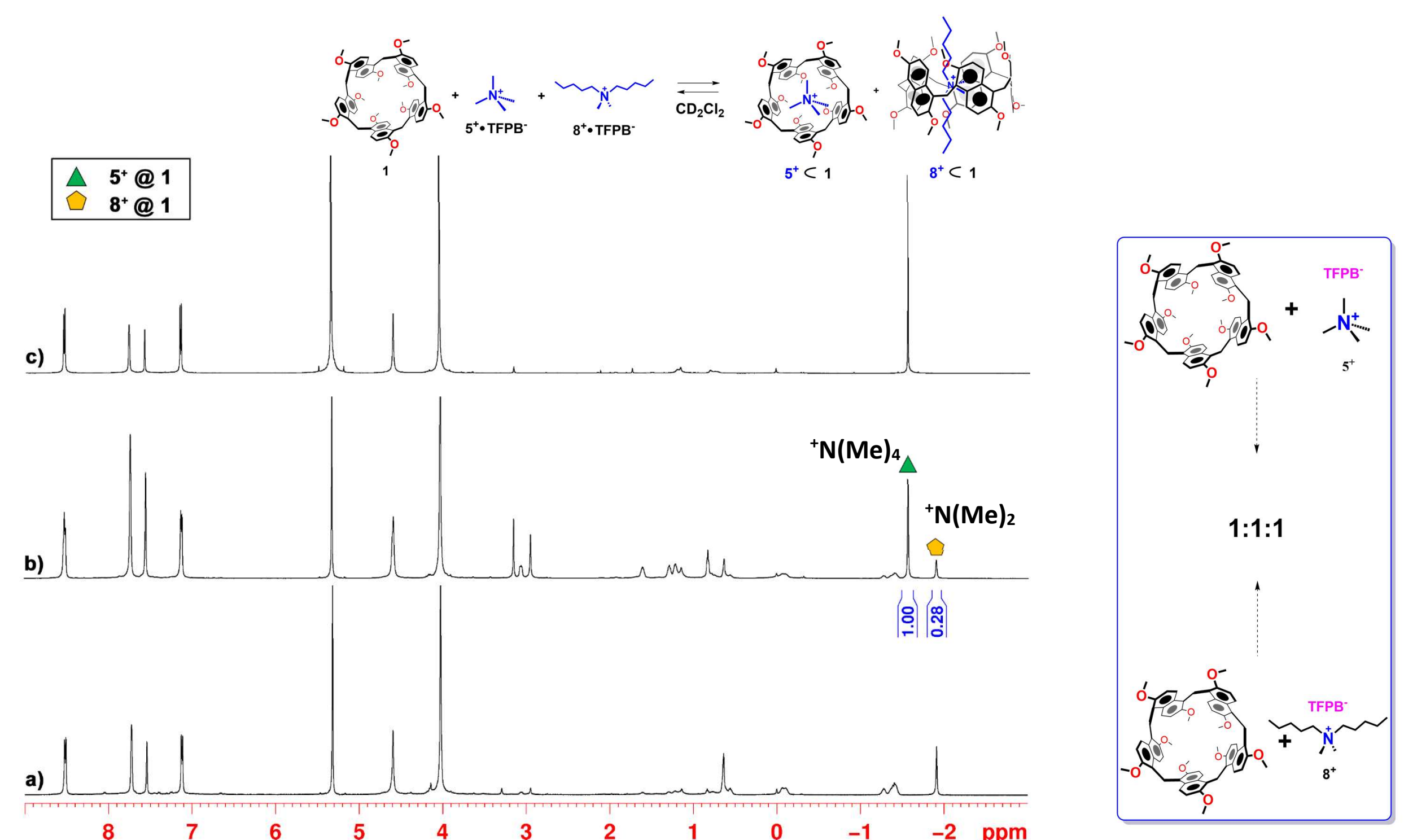

Figure S63: ${ }^{1} \mathrm{H}$ NMR spectra $\left(600 \mathrm{MHz}, \mathrm{CD}_{2} \mathrm{Cl}_{2}, 183 \mathrm{~K}\right)$ of: (a) an equimolar solution $(2.85 \mathrm{mM})$ of $\mathbf{1}$ and $\mathbf{8}^{+} \cdot \mathbf{T F P B}^{-}$in $0.7 \mathrm{~mL}$ of $\mathrm{CD}_{2} \mathrm{Cl}_{2},(\mathrm{~b})$ of $\mathbf{1}$ in thepresence of 1 equivalent of $\mathbf{8}^{+} \cdot \mathbf{T F P B}^{-}$and 1 equivalent of $\mathbf{5}^{+} \cdot \mathbf{T F P B}^{-}$and (c) an equimolar solution $(2.85 \mathrm{mM})$ of $\mathbf{1}$ and $\mathbf{5}^{+} \cdot \mathbf{T F P B}^{-}$in $0.7 \mathrm{~mL}$ of $\mathrm{CD}_{2} \mathrm{Cl}_{2}$. 


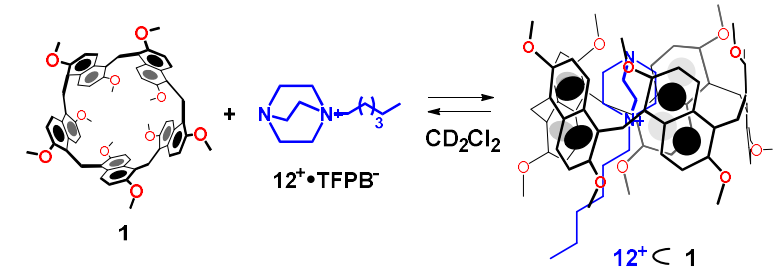

Complexed Guest
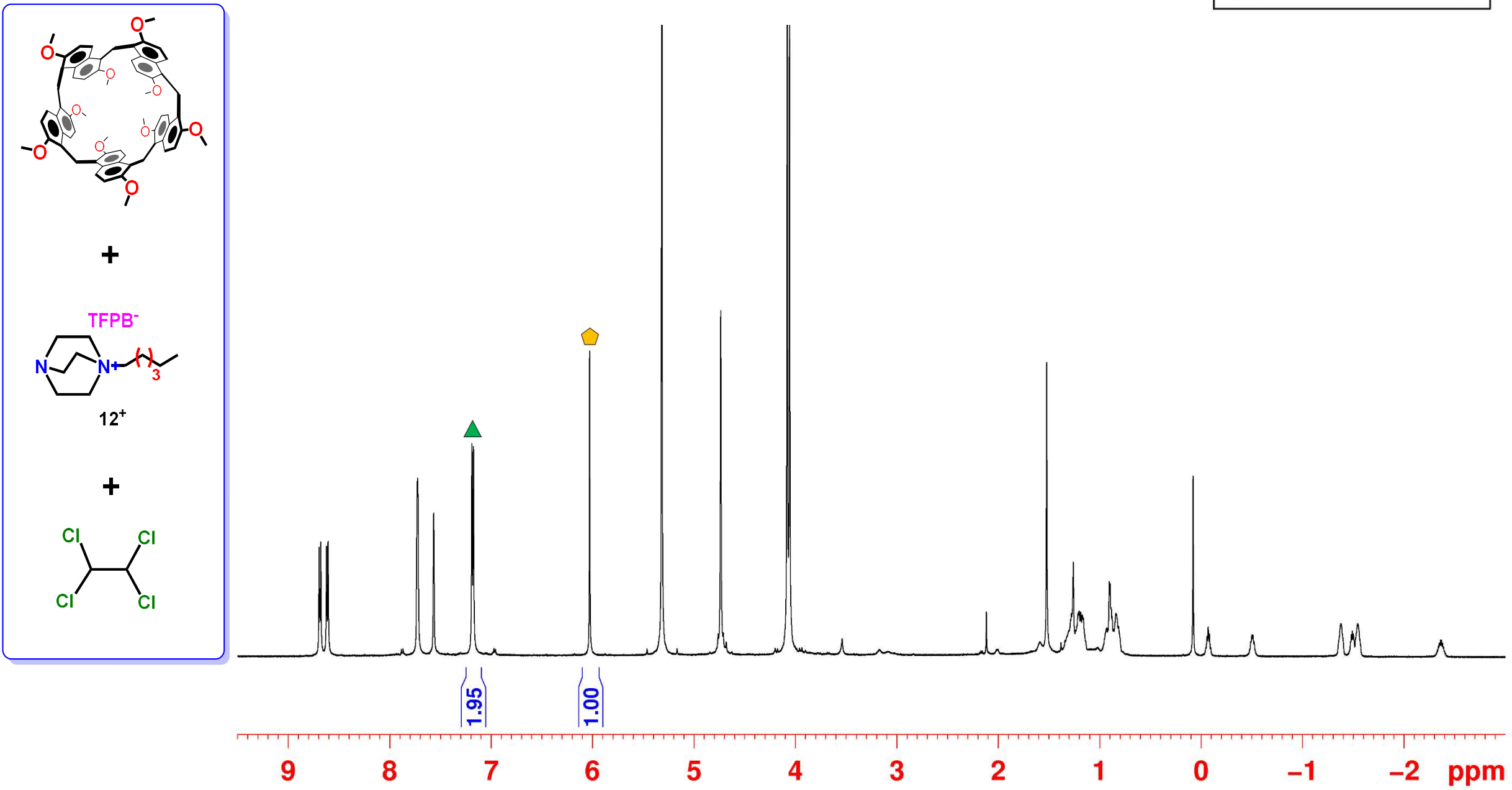

Figure S64: ${ }^{1} \mathrm{H}$ NMR spectrum $\left(600 \mathrm{MHz}, \mathrm{CD}_{2} \mathrm{Cl}_{2}, 298 \mathrm{~K}\right)$ of an equimolar solution $(2.85 \mathrm{mM})$ of $\mathbf{1}$ and $\mathbf{1 2}^{+} \cdot \mathbf{T F P B}^{-}$in $0.7 \mathrm{~mL}$ of $\mathrm{CD}_{2} \mathrm{Cl}_{2}$ containing $0.5 \mu \mathrm{L}$ of $1,1,2,2$-tetrachloroethane. 


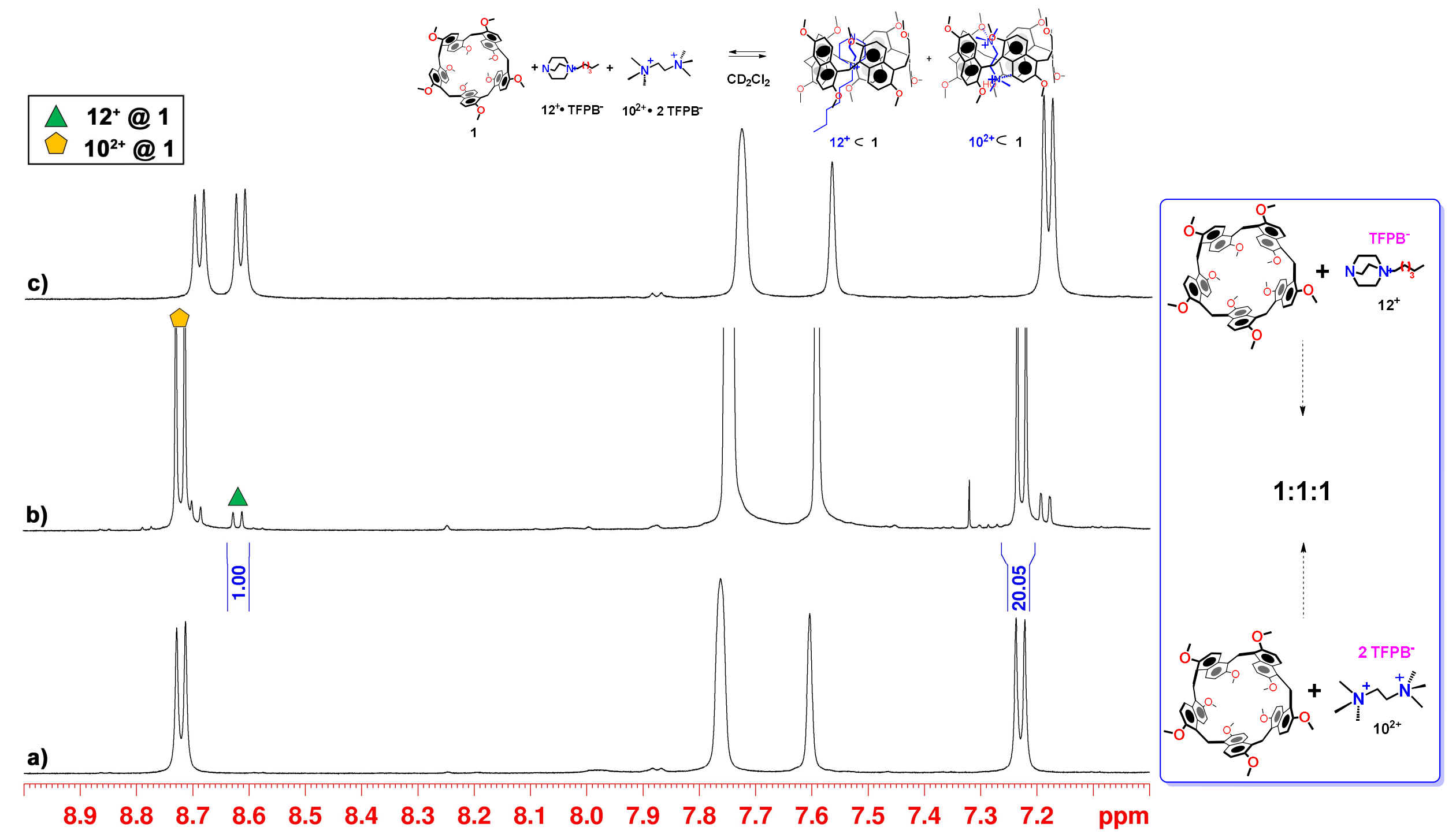

Figure S65: Significant portions of the ${ }^{1} \mathrm{H}$ NMR spectra $\left(600 \mathrm{MHz}, \mathrm{CD}_{2} \mathrm{Cl}_{2}, 298 \mathrm{~K}\right)$ of: (a) an equimolar solution (2.85 mM) of $\mathbf{1}$ and $\mathbf{1 0}^{\mathbf{2} \cdot} \mathbf{2}$ TFPB $^{-}$in $0.7 \mathrm{~mL}$ of $\mathrm{CD}_{2} \mathrm{Cl}_{2}$, (b) of $\mathbf{1}$ in the presence of 1 equivalent of $\mathbf{1 0}^{\mathbf{2}} \cdot \mathbf{2} \mathbf{T F P B}^{-}$and 1 equivalent of $\mathbf{1 2}^{+} \cdot \mathbf{T F P B}^{-}$and (c) an equimolar solution $(2.85 \mathrm{mM})$ of $\mathbf{1}$ and $\mathbf{1 2}^{+} \cdot \mathbf{T F P B}^{-}$in $0.7 \mathrm{~mL}$ of $\mathrm{CD}_{2} \mathrm{Cl}_{2}$. 


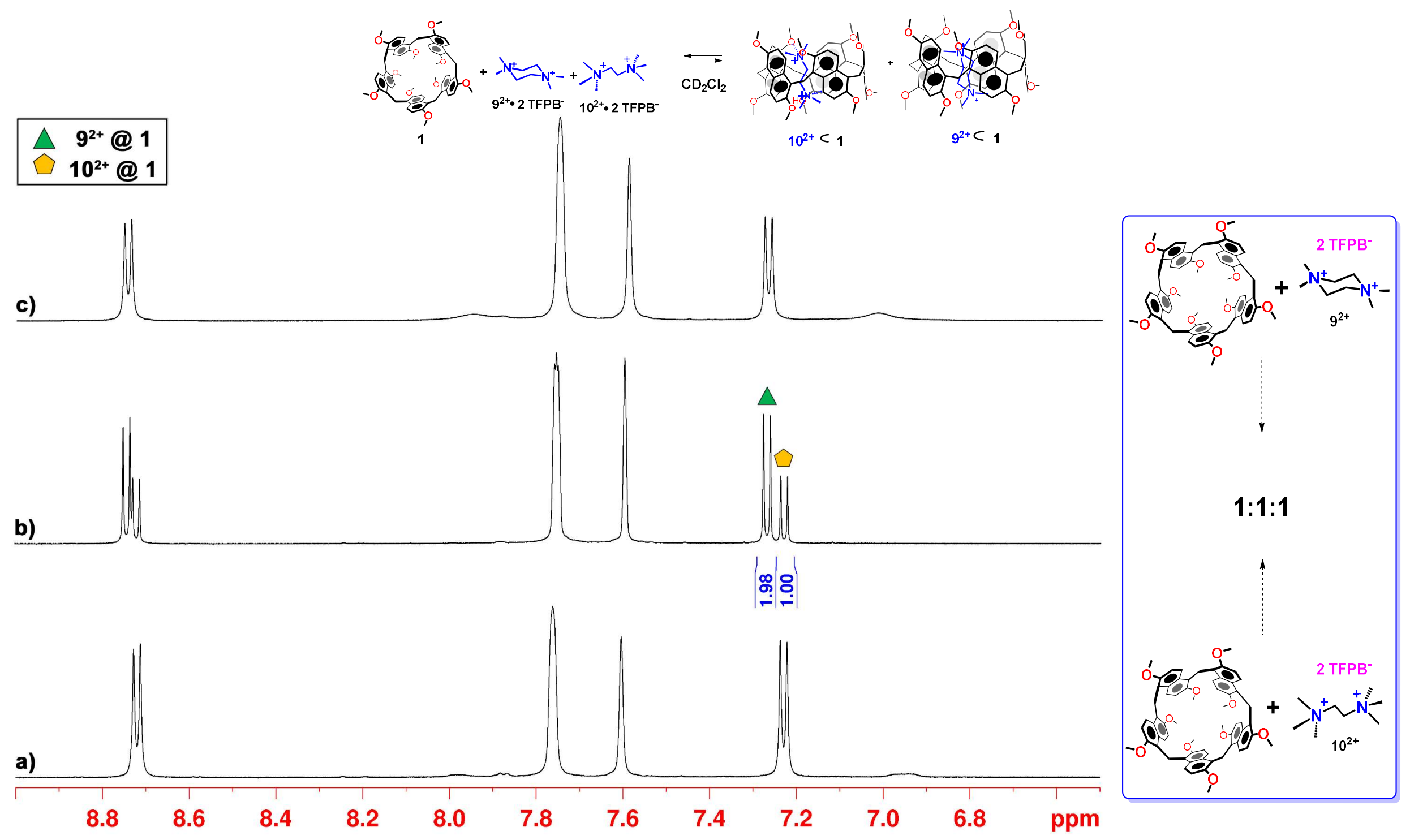

Figure S66: Significant portions of the ${ }^{1} \mathrm{H}$ NMR spectra $\left(600 \mathrm{MHz}, \mathrm{CD}_{2} \mathrm{Cl}_{2}, 298 \mathrm{~K}\right)$ of: (a) an equimolar solution $(2.85 \mathrm{mM})$ of $\mathbf{1}$ and $\mathbf{1 0}{ }^{2+} \cdot \mathbf{2}$

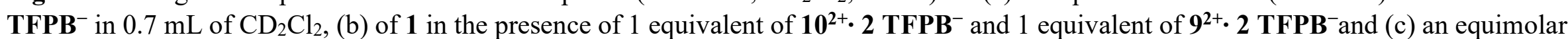

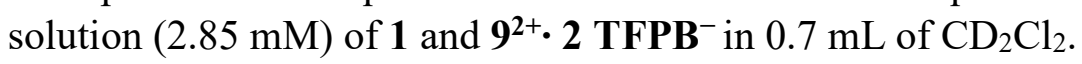



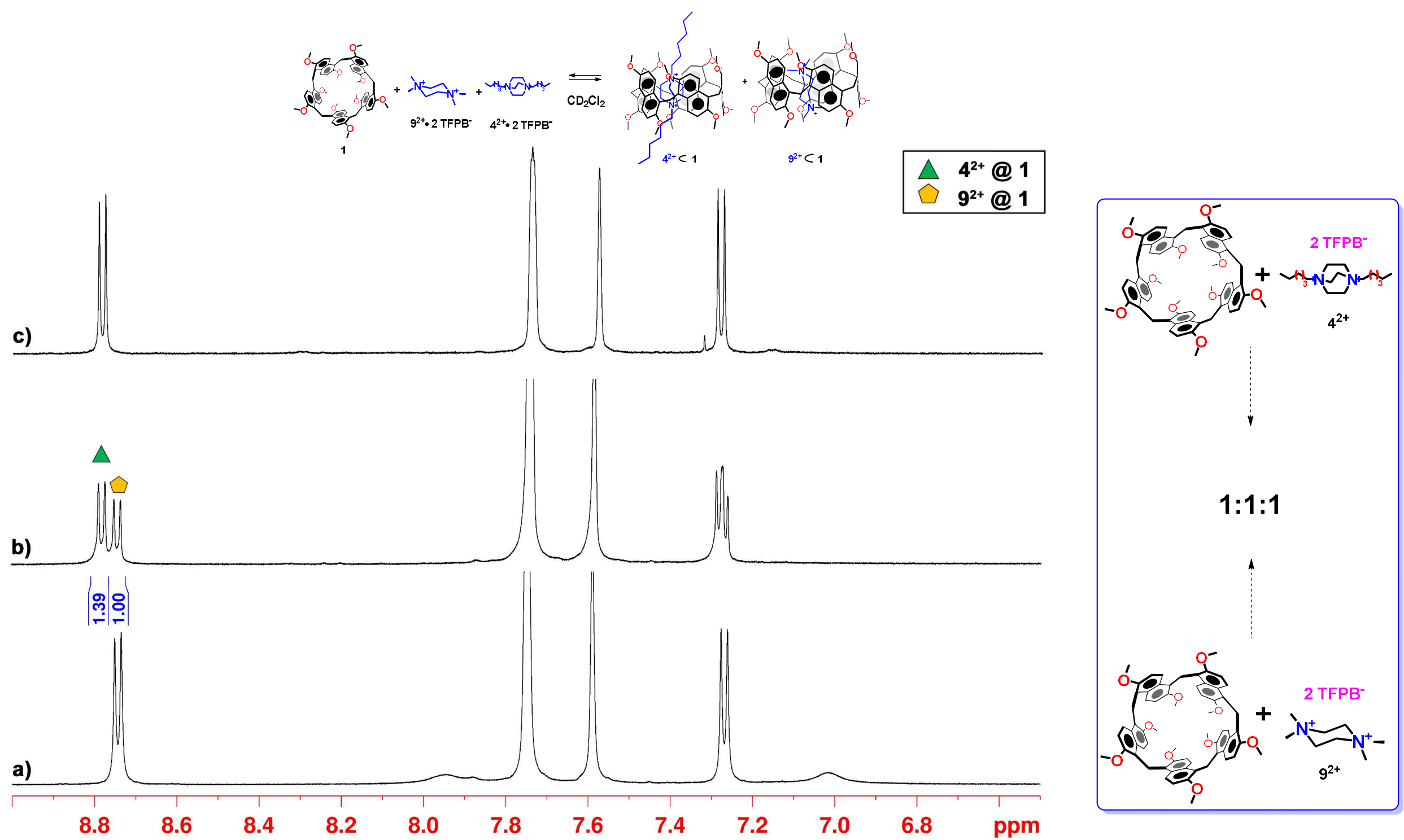

Figure S67: Significant portions of the ${ }^{1} \mathrm{H}$ NMR spectra $\left(600 \mathrm{MHz}, \mathrm{CD}_{2} \mathrm{Cl}_{2}, 298 \mathrm{~K}\right)$ of: (a) an equimolar solution $(2.85 \mathrm{mM})$ of 1 and $\mathbf{9}^{2+} \cdot \mathbf{2}$ TFPB in $0.7 \mathrm{~mL}$ of $\mathrm{CD}_{2} \mathrm{Cl}_{2}$, (b) of $\mathbf{1}$ in the presence of 1 equivalent of $\mathbf{4}^{2+} \cdot \mathbf{2} \mathbf{T F P B}^{-}$and 1 equivalent of $\mathbf{9}^{2+} \cdot \mathbf{2} \mathbf{T F P B}^{-}$and (c) an equimolar solution (2.85 $\mathrm{mM}$ ) of 1 and $\mathbf{4}^{2+} \cdot \mathbf{2} \mathbf{T F P B}^{-}$in $0.7 \mathrm{~mL}$ of $\mathrm{CD}_{2} \mathrm{Cl}_{2}$. 


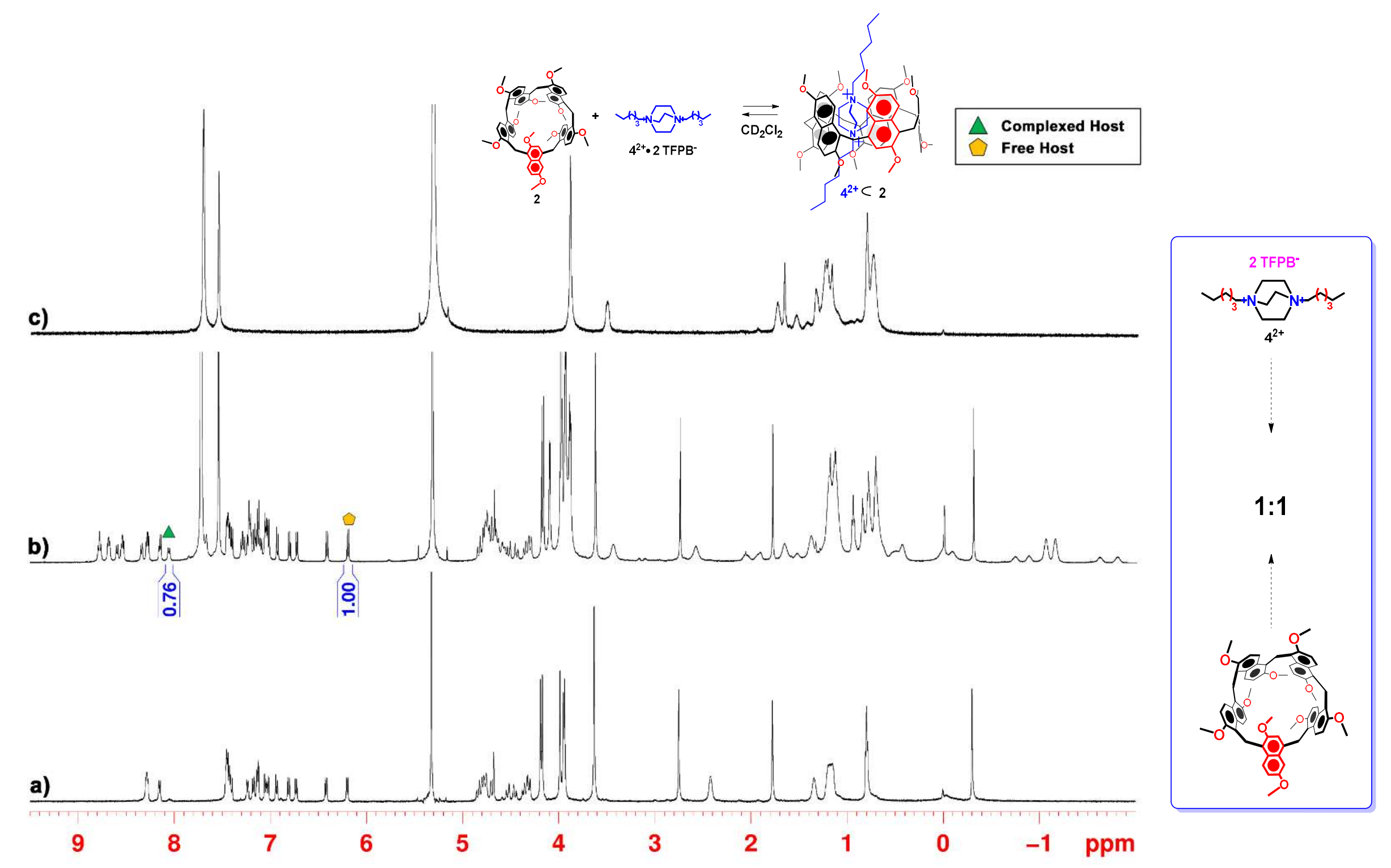

Figure S68: ${ }^{1} \mathrm{H}$ NMR spectra $\left(600 \mathrm{MHz}, \mathrm{CD}_{2} \mathrm{Cl}_{2}, 183 \mathrm{~K}\right)$ of: (a) a solution of $\mathbf{2}$ (b) an equimolar solution (2.85 $\left.\mathrm{mM}\right)$ of 2 and $\mathbf{4}^{\mathbf{2 +} \cdot 2} \mathbf{2} \mathbf{T P B}{ }^{-}$in 0.7 $\mathrm{mL}$ of $\mathrm{CD}_{2} \mathrm{Cl}_{2}$ and (c) a solution of $\mathbf{4}^{2+} \cdot \mathbf{2} \mathbf{T F P B}^{-}$. 

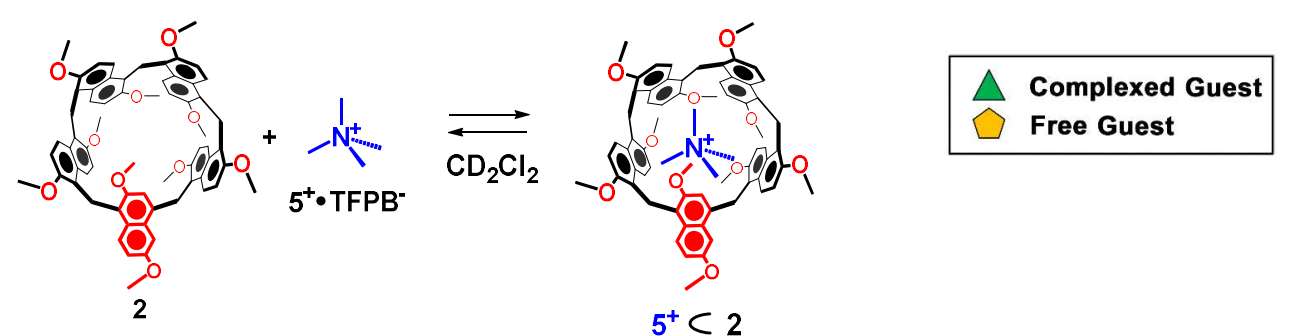

c)

b)
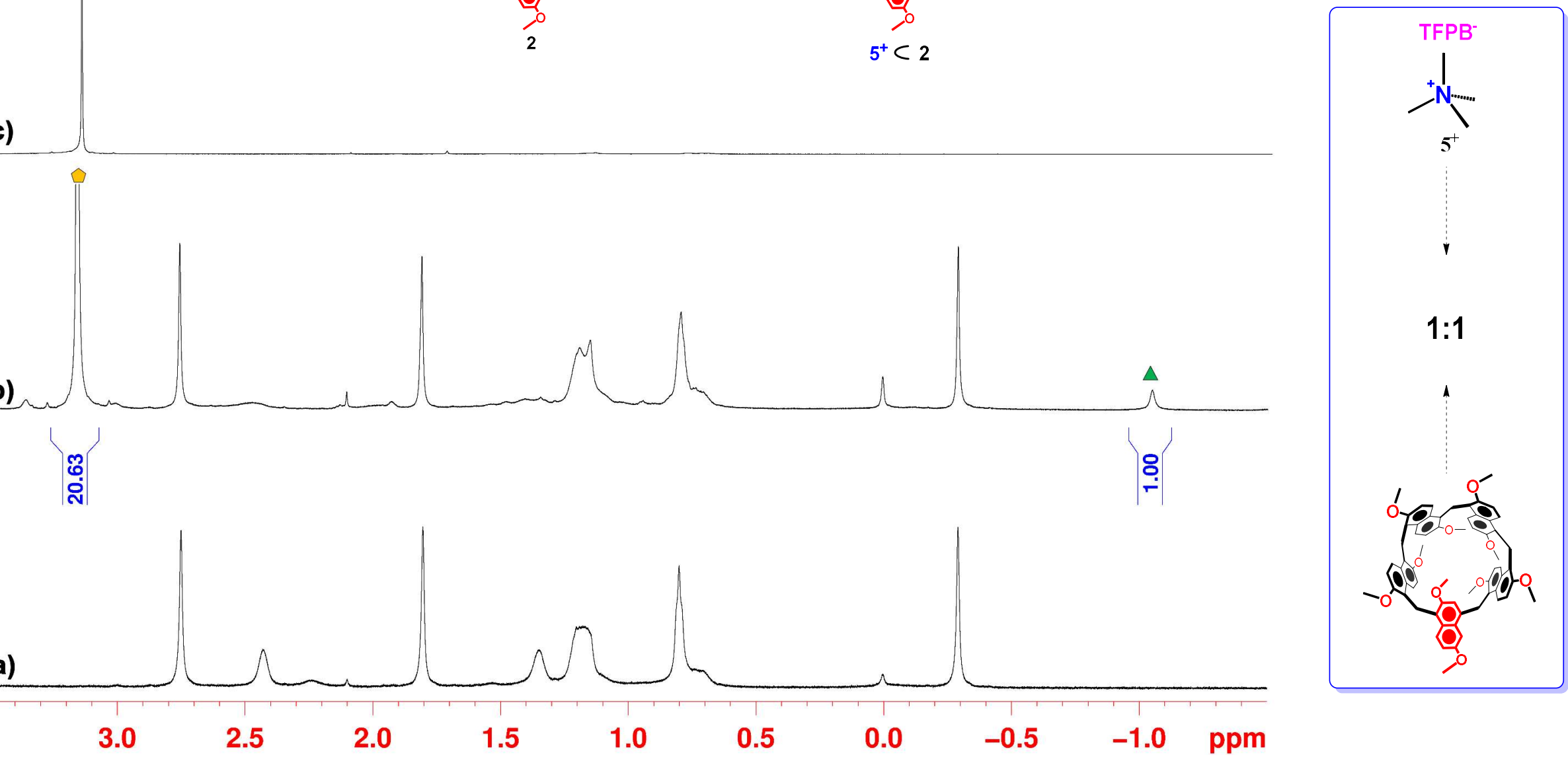

Figure S69: Significant portions of the ${ }^{1} \mathrm{H} N \mathrm{NR}$ spectra $\left(600 \mathrm{MHz}, \mathrm{CD}_{2} \mathrm{Cl}_{2}, 183 \mathrm{~K}\right)$ of: (a) a solution of 2 (b) an equimolar solution (2.85 mM) of 2 and $\mathbf{5}^{+} \mathbf{T F P B}^{-}$in $0.7 \mathrm{~mL}$ of $\mathrm{CD}_{2} \mathrm{Cl}_{2}$ and (c) a solution of $\mathbf{5}^{+}$. $\mathbf{T F P B}^{-}$. 
c)

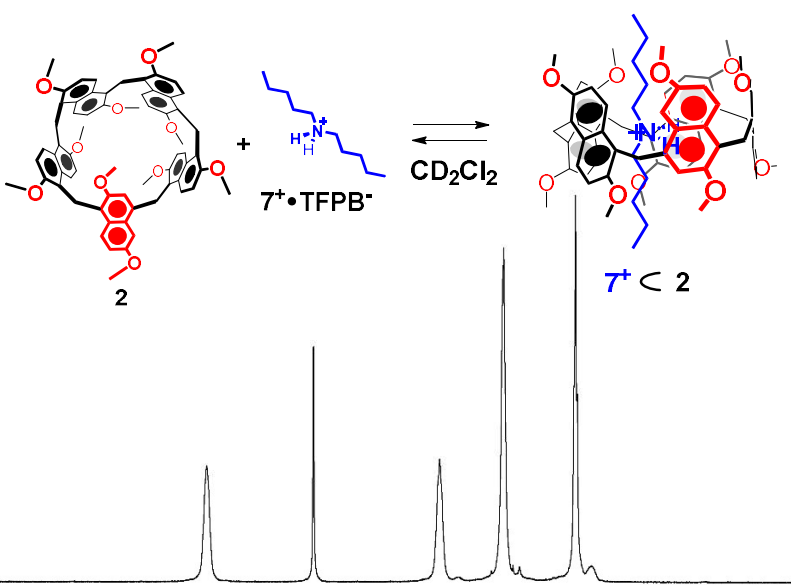

$\triangle$ Complexed Host Free Host
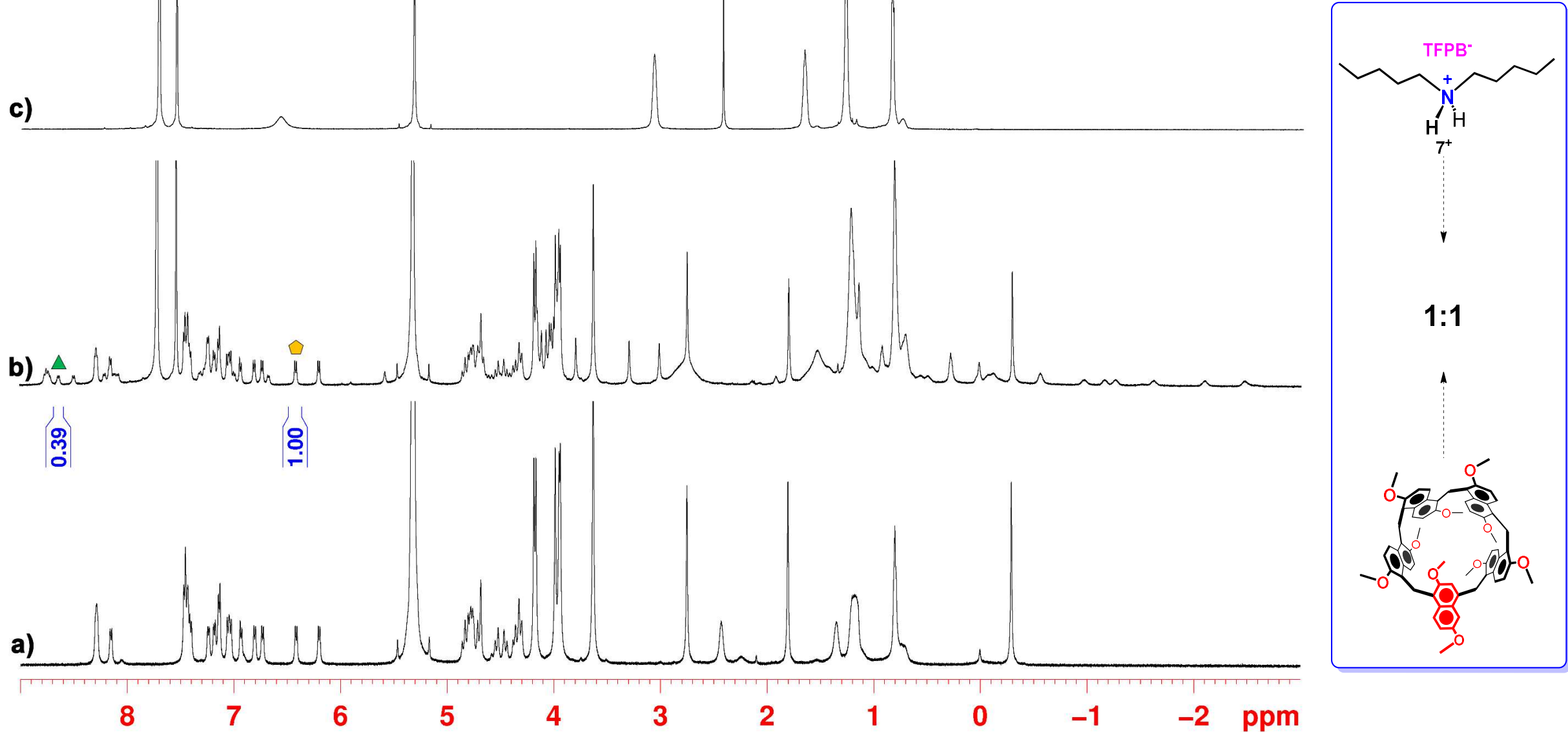

Figure S70: ${ }^{1} \mathrm{H}$ NMR spectra $\left(600 \mathrm{MHz}, \mathrm{CD}_{2} \mathrm{Cl}_{2}, 183 \mathrm{~K}\right.$ ) of: (a) a solution of $\mathbf{2}$ (b) an equimolar solution $(2.85 \mathrm{mM})$ of $\mathbf{2}$ and $7^{+} \cdot \mathbf{T F P B}^{-}$in $0.7 \mathrm{~mL}$ of $\mathrm{CD}_{2} \mathrm{Cl}_{2}$ and (c) a solution of $\mathbf{7}^{+} \cdot$ TFPB $^{-}$. 


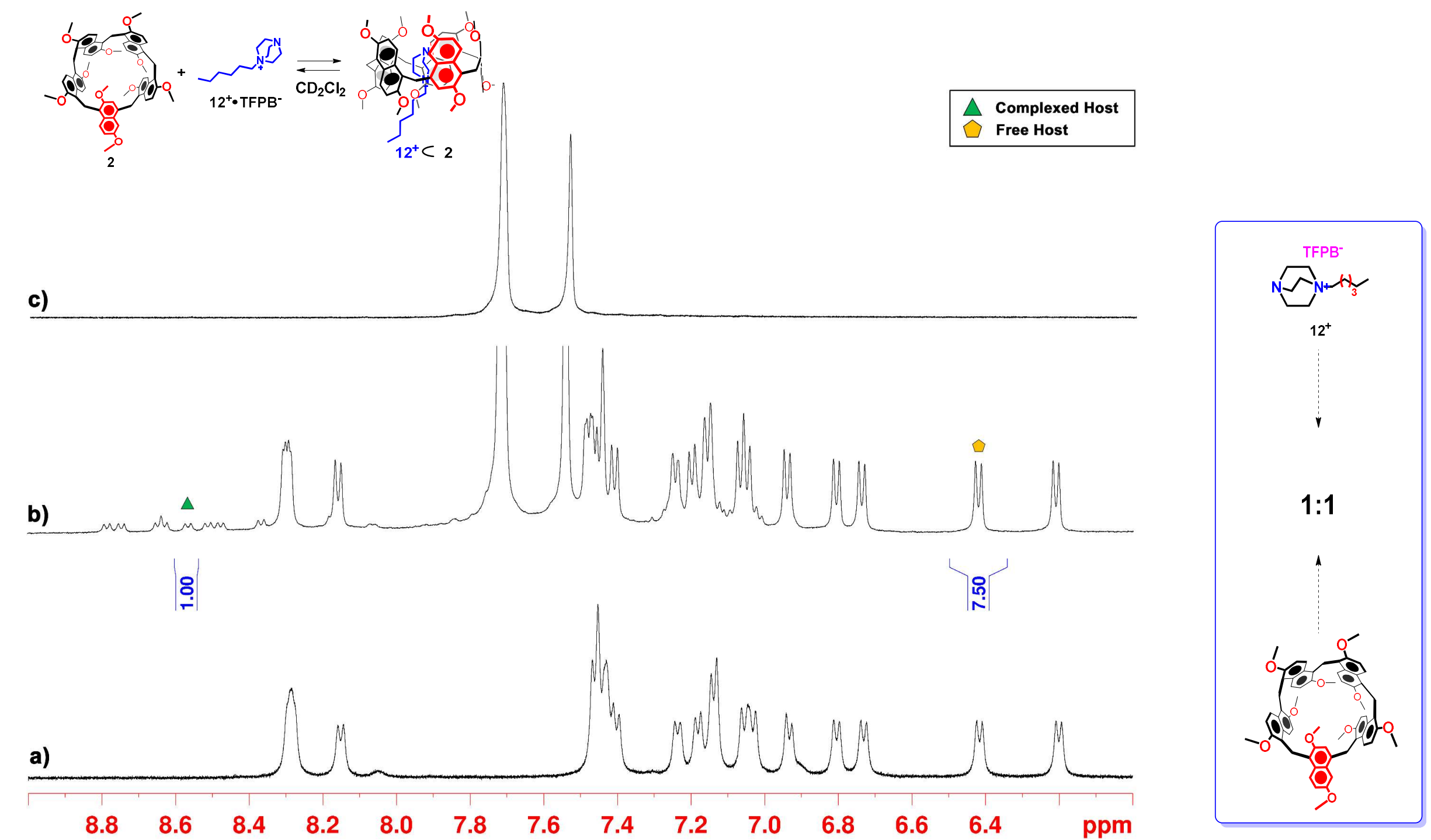

Figure S71: Significant portion of the ${ }^{1} \mathrm{H}$ NMR spectra $\left(600 \mathrm{MHz}, \mathrm{CD}_{2} \mathrm{Cl}_{2}, 183 \mathrm{~K}\right)$ of: (a) a solution of 2 (b) an equimolar solution (2.85 mM) of 2 and $\mathbf{1 2}^{+} \cdot$ TFPB $^{-}$in $0.7 \mathrm{~mL}$ of $\mathrm{CD}_{2} \mathrm{Cl}_{2}$ and (c) a solution of $\mathbf{1 2}^{+} \cdot$ TFPB $^{-}$. 
c)

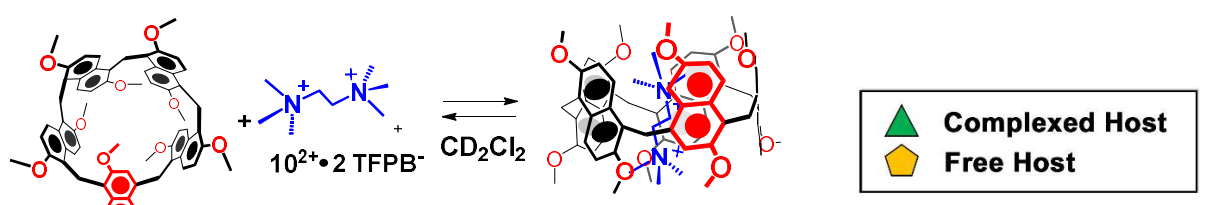

$\underline{1}$
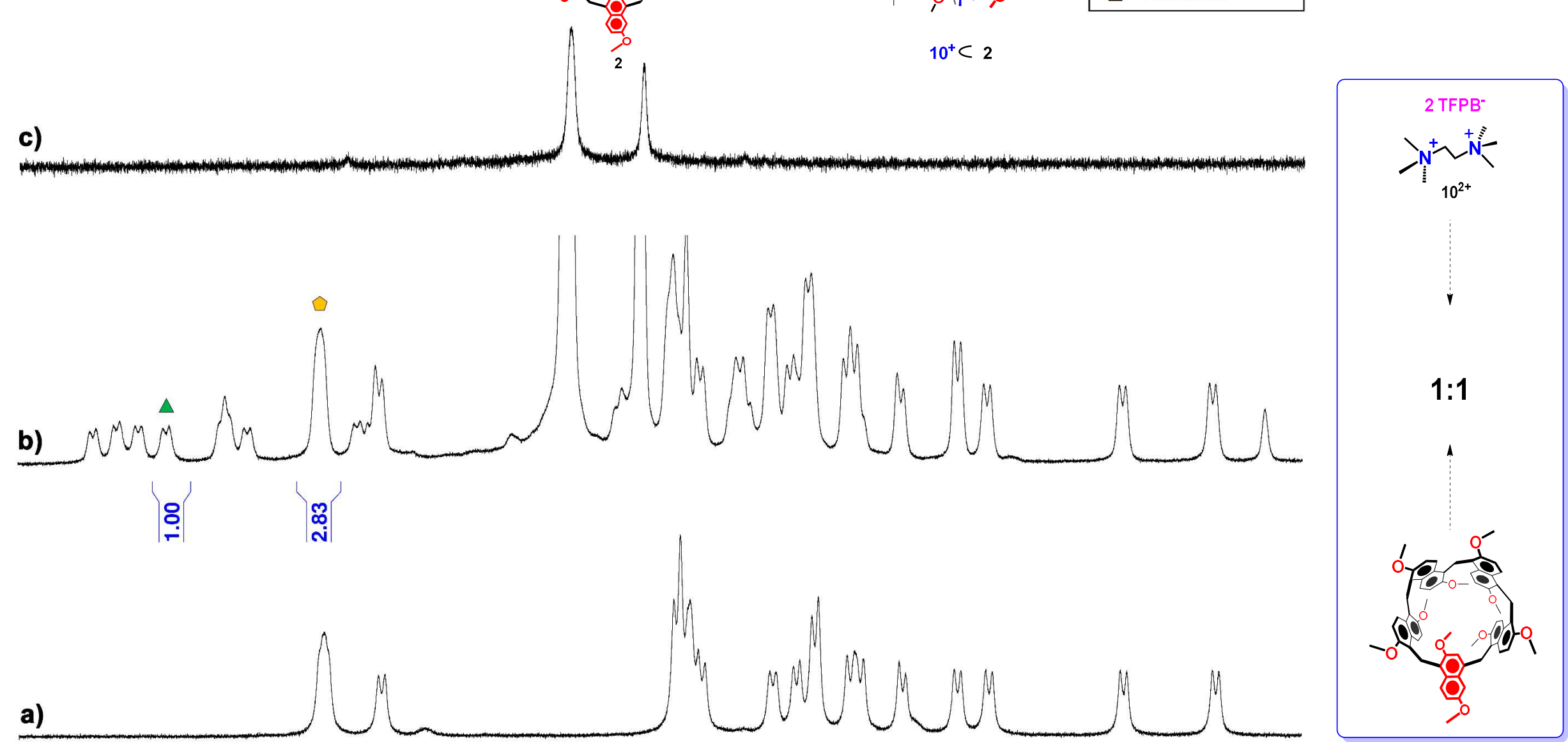

a)

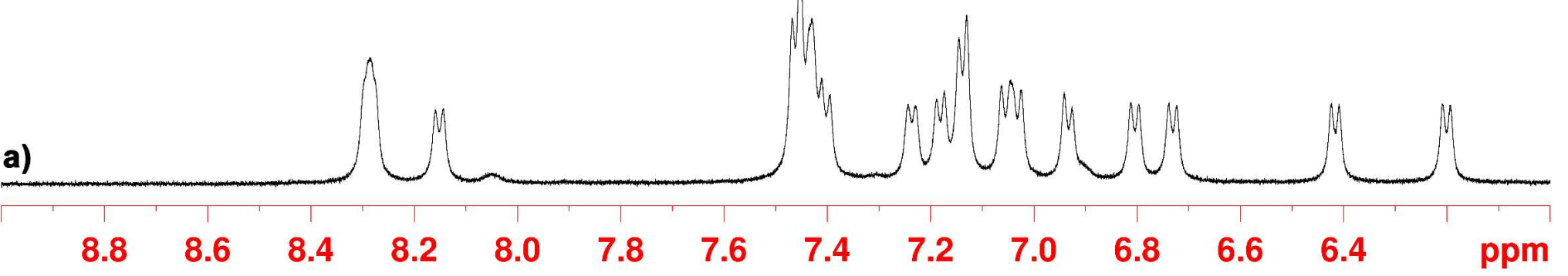

Figure S72: Significant portions of the ${ }^{1} \mathrm{H} N M R$ spectra $\left(600 \mathrm{MHz}, \mathrm{CD}_{2} \mathrm{Cl}_{2}, 183 \mathrm{~K}\right)$ of: (a) a solution of 2 (b) an equimolar solution (2.85 mM) of 2 and $\mathbf{1 0}^{2+} \cdot \mathbf{2} \mathbf{T F P B}^{-}$in $0.7 \mathrm{~mL}$ of $\mathrm{CD}_{2} \mathrm{Cl}_{2}$ and (c) a solution of $\mathbf{1 0}^{2+} \cdot \mathbf{2}$ TFPB $^{-}$. 


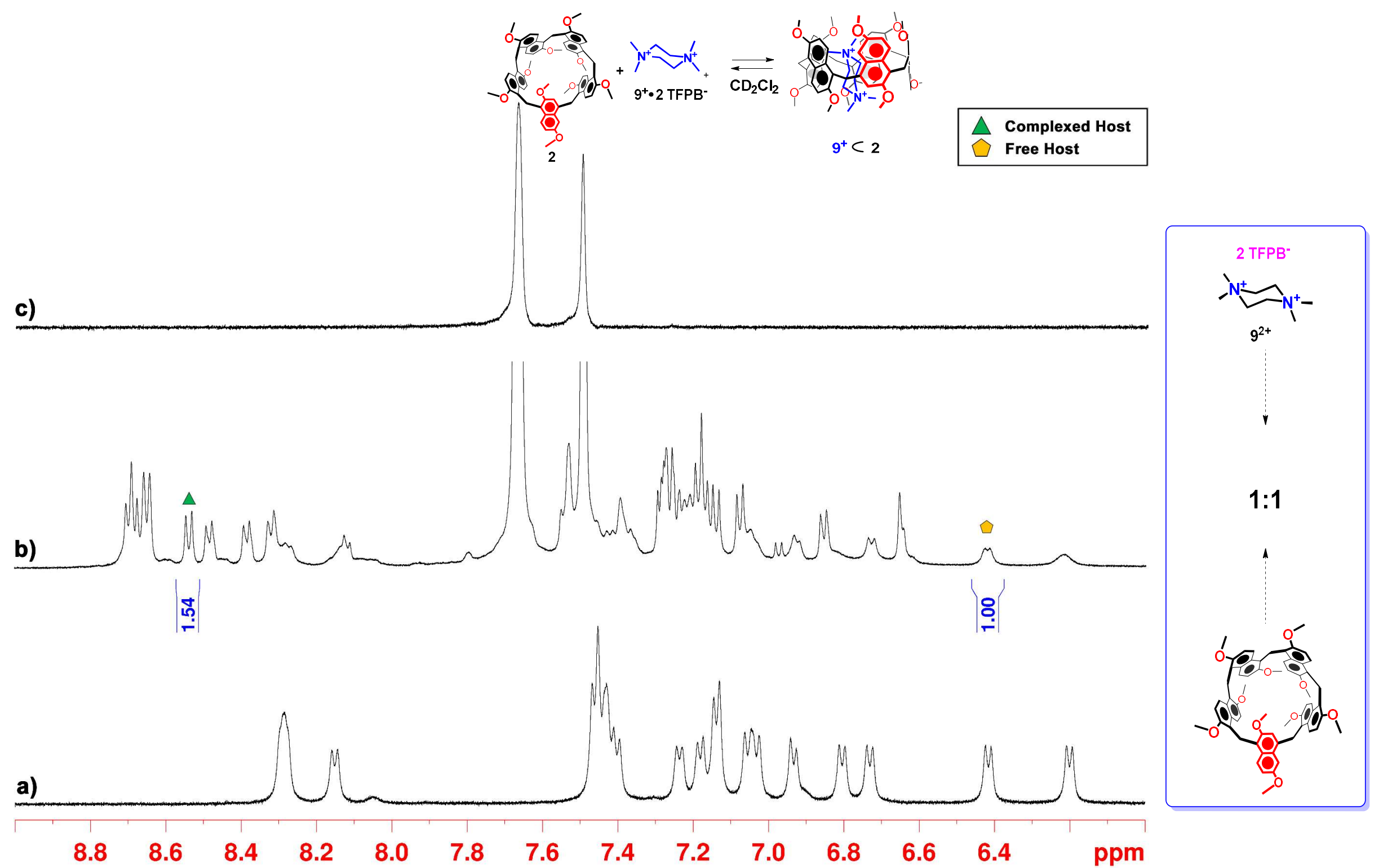

Figure S73: Significant portions of the ${ }^{1} \mathrm{H} N \mathrm{NR}$ spectra $\left(600 \mathrm{MHz}, \mathrm{CD}_{2} \mathrm{Cl}_{2}, 183 \mathrm{~K}\right)$ of: (a) a solution of 2 (b) an equimolar solution (2.85 mM) of 2 and $\mathbf{9}^{2+} \cdot \mathbf{2} \mathbf{T F P B}^{-}$in $0.7 \mathrm{~mL}$ of $\mathrm{CD}_{2} \mathrm{Cl}_{2}$ and (c) a solution of $\mathbf{9}^{2+} \cdot \mathbf{2} \mathbf{T F P B}^{-}$ 


\section{HPLC analysis of the cyclocondensation kinetics}

All samples were analyzed on $250 \times 4.6 \mathrm{~mm}$ Waters Spherisorb ${ }^{\circledR} 10 \mu \mathrm{m}$ Silica using dichloromethaneisopropanol $99.7 / 0.3 \mathrm{v} / \mathrm{v}$ as the mobile phase at a flow rate of $0.8 \mathrm{ml} / \mathrm{min}$ and injecting $20 \mu \mathrm{L}$ of $10 \mu \mathrm{g} / \mathrm{mL}$ solution of reaction mixture in dichloromethane. The retention times are as follows: 2 (7.1 $\min$ ) and 1 (11.0 $\mathrm{min})$.

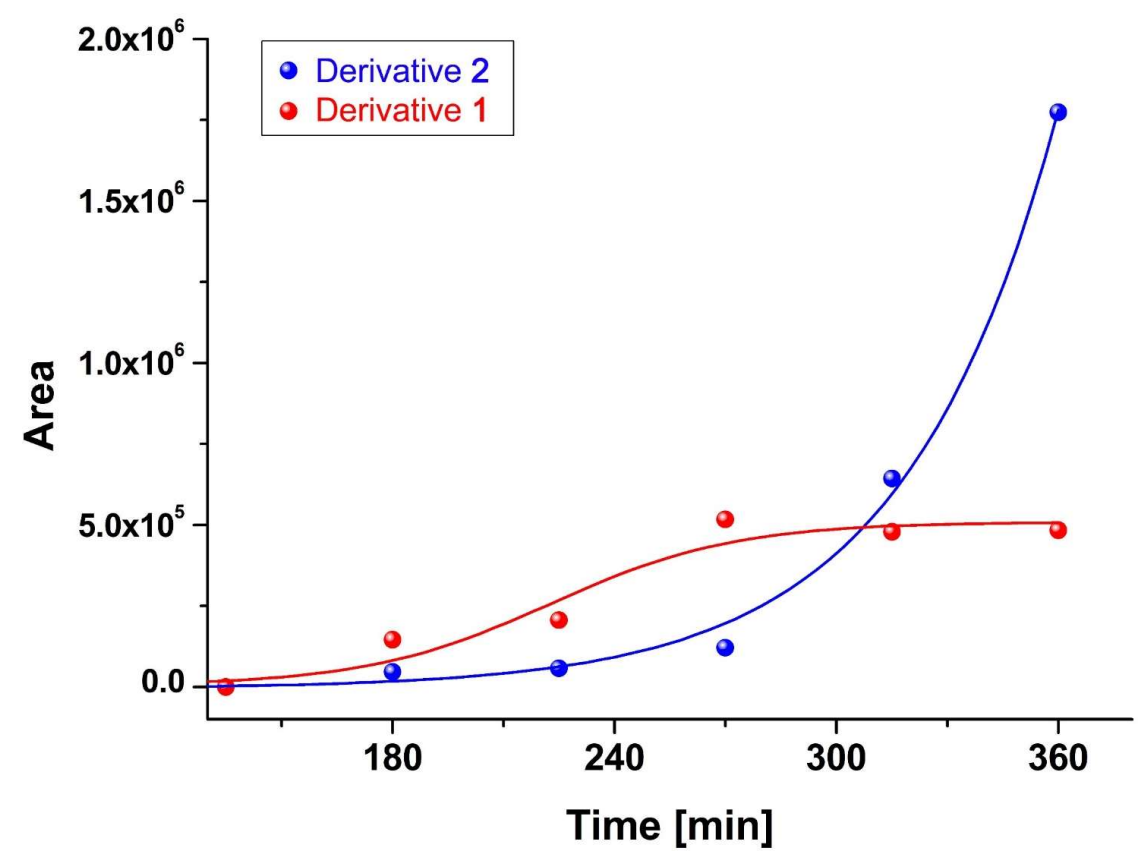

Figure S74: Relationship between time and products distribution in the cyclocondensation reactions without templanting agent.

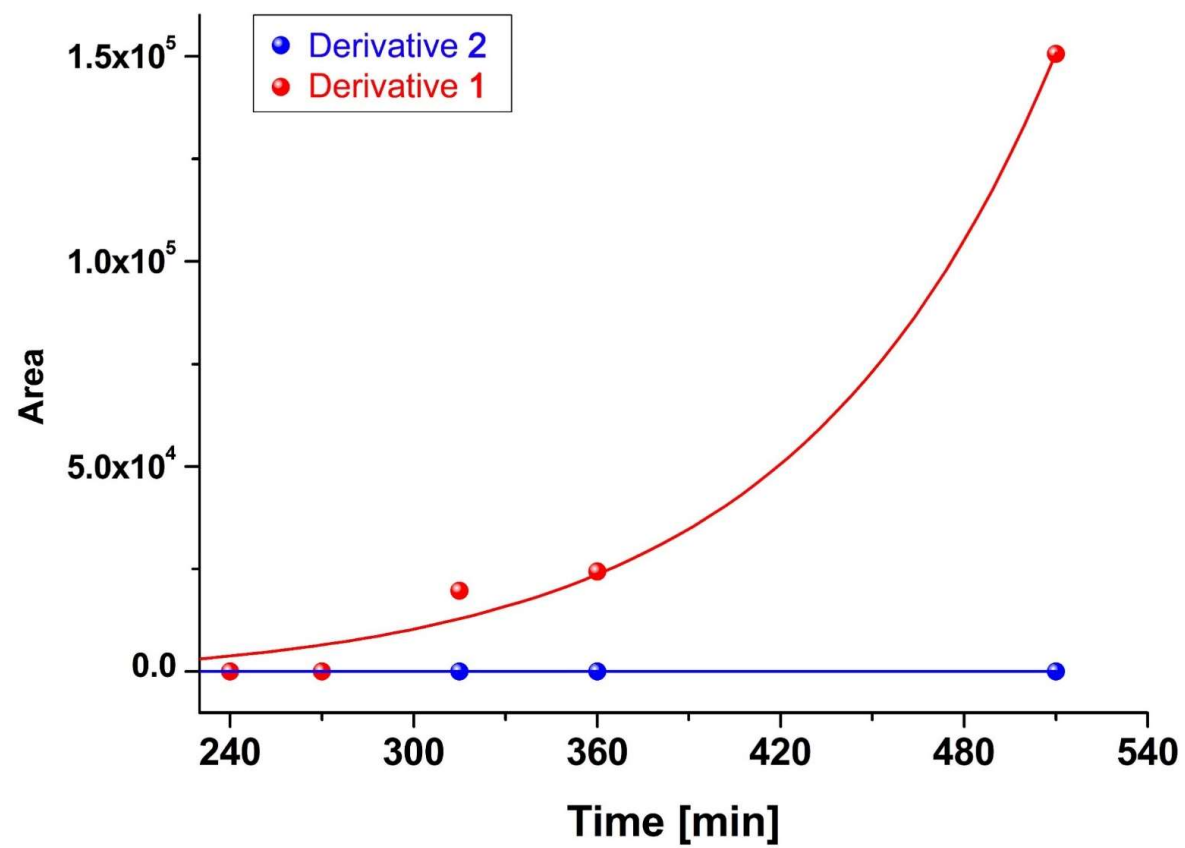

Figure S75: Relationship between time and products distribution in the cyclocondensation reactions in the presence of templating agent $\mathbf{4}^{\mathbf{2}}$. 


\section{Determination of the crystallographic structures of Prism[5]arenes (1) and 1,4- confused-Prism[5]arenes (2)}

Single crystals suitable for X-ray investigation were obtained by slow evaporation of solutions containing prism[5] arene (1) or 1,4-C-prism[5] arene (2) in various crystallisation trials. Data collection was carried out at the Macromolecular crystallography XRD1 beamline of the Elettra synchrotron (Trieste, Italy), employing the rotating-crystal method with a Dectris Pilatus $2 \mathrm{M}$ area detector. Single crystals investigated were dipped in a cryo-protectant (PEG200 or Paratone), mounted on a loop and flash-frozen under a liquid nitrogen stream at $100 \mathrm{~K}$. Further details of the crystallisation conditions and the cryoprotectant used are outlined below. Diffraction data were indexed and integrated using the XDS package, ${ }^{5}$ while scaling was carried out with XSCALE. ${ }^{6}$ The structures were solved using the SHELXT package, $;^{7}$ and structure refinement was performed with SHELXL- $14,{ }^{8}$ operating through the WinGX GUI, ${ }^{9}$ by full-matrix least- squares (FMLS) methods on $\mathrm{F}^{2}$.

Three pseudo-polymorphic forms of prism[5] arene ( $\alpha, \beta$ and $\gamma$, space groups P-1, P-1 and C2/c, respectively) and two pseudo-polymorphic forms of 1,4-confused-prism[5]arene ( $\alpha$ and $\beta$, space groups $\mathrm{P} 21 / \mathrm{c}$ and $\mathrm{P}-1$, respectively) were analysed. PEG 200 was used as cryoprotectant for both forms of 1,4-confused-prism[5] arene and the $\gamma$ form of prism[5] arene, while paratone was used for the other two forms of prism[5] arene. For all the reported structures, the thermal parameters of the nonhydrogen atoms were refined anisotropically with the exception of atoms at or below $50 \%$ occupancy, which were refined isotropically. All hydrogen atoms were placed at the geometrically calculated positions and refined using the riding model. Crystal data and final refinement details for the structures are reported in Tables $\mathbf{S 2}$ and $\mathbf{S 3}$

\section{Prism[5]arenes}

The three prism[5]arenes pseudo-polymorphs were obtained as colourless crystals in separate crystallisation trials. The solvent systems used were $\mathrm{CH}_{2} \mathrm{Cl}_{2}$ / hexane for the $\alpha$ form and $\mathrm{CH}_{2} \mathrm{Cl}_{2} /$ ethyl acetate for the $\beta$ and $\gamma$ forms. In the case of the $\beta$ form, dipentylammonium hexafluoride salt was also added to the crystallisation solution. In all three crystalline forms the asymmetric unit contains one molecule of prism[5] arene 1 with a co-crystallized $\mathrm{CH}_{2} \mathrm{Cl}_{2}$ solvent molecule encapsulated in the prismarenes ring. The three pseudo-polymorphs are distinguished by a different amount of co-crystallized $\mathrm{CH}_{2} \mathrm{Cl}_{2}$ solvent molecules located between the packed molecules of 1 outside the prismarenes rings. In the case of the $\alpha$ form, the asymmetric unit contains two additional external $\mathrm{CH}_{2} \mathrm{Cl}_{2}$ molecules; while in the $\beta$ form there is just one external site partially occupied by a disordered $\mathrm{CH}_{2} \mathrm{Cl}_{2}$. Finally, $\gamma$ form contains the encapsulated $\mathrm{CH}_{2} \mathrm{Cl}_{2}$ molecule only. In the case of the $\beta$ form, both $\mathrm{CH}_{2} \mathrm{Cl}_{2}$ molecules are disordered over two positions, with $90 \% / 10 \%$ occupancy for the encapsulated molecule and $80 \% / 10 \%$ occupancy for the partially occupied external site. For the $\gamma$ form, the encapsulated $\mathrm{CH}_{2} \mathrm{Cl}_{2}$ molecule is disordered over two positions related by the crystallographic two-fold axis and it is therefore refined with $50 \%$ occupancy factor. 


\section{1,4-C-Prism[5]arenes}

The two pseudo-polymorphic forms of 1,4-C-prism[5]arene, 2 were obtained as white crystals. The solvent systems used were $\mathrm{CH}_{2} \mathrm{Cl}_{2}$ / decaline for the $\alpha$ form and $\mathrm{CH}_{2} \mathrm{Cl}_{2}$ / pyridine for the $\beta$ form. The structure refinements of both crystal forms were refined as two-component non-merohedral twins. The twin laws $(1,0,0 ; 0,-1,0 ;-0.052,0,-1)$, which corresponds to a twofold axis about the $\left[\begin{array}{lll}1 & 0 & 0\end{array}\right]$ direct lattice direction in the $\alpha$ form, and $(-1,0,0 ;-0.164,1,-0.893 ; 0,0,-1)$, which corresponds to a twofold axis about the [0 5 -2] direct lattice direction in the $\beta$ form, were detected with PLATON TwinRoMat. The fraction of overlapped reflections was calculated at $13 \%$ and $18 \%$ for the $\alpha$ and $\beta$ forms, respectively. The refinement as a 2-component twin with a HKLF5 reflection file reduced the $\mathrm{R}$-factor significantly in both cases. The $\mathrm{R}_{1}$ factors without twin refinement were 0.1526 and 0.1704 for the $\alpha$ and $\beta$ forms, respectively, to compare with the twin refinement values of 0.0890 and 0.1213 , respectively. The twin component is similar for the $\alpha$ and $\beta$ forms (refined BASF factors 0.43(5) and 0.43(4) for $\alpha$ and $\beta$ forms, respectively).

The asymmetric unit of the monoclinic $\alpha$ form is composed of two molecules of 2 . Both forms show a similar disorder in the position of the methoxy groups of the 1,4-naphthalene ring, corresponding to an overlap of two positions of the molecule related by a pseudo-twofold axis passing through the 1,4-naphthalene ring and the opposite methylene bridge, and which differ in the positions of the two methoxy groups of the 1,4-naphthalene ring. For both independent molecules the occupancy factor ratio of this disorder is $80 / 20 \%$. For one of the independent molecules the methyl group of one of the two methoxy substituents is further disordered over two positions, refined at $50 \%$ and $30 \%$ of full occupancy. Furthermore, the methyl group of a methoxy substituent on the other independent molecule - specifically the methoxy group of naphthalene C' (see Figure S82 for designation of naphthalene rings) tilted towards the 1,4-naphthalene ring - is disordered over two positions, refined at $70 \%$ and $30 \%$ occupancy.

The asymmetric unit of the triclinic $\beta$ form is composed of one molecule of $\mathbf{2}$ with residual electron density attributed to severely disordered dichloromethane solvent molecules. The latter was not modelled but was accounted for using the Platon squeeze tool. The residual electron density of 49 electrons/cell in a total potential solvent accessible void volume of 296.3 (10.8\% of the cell volume) can be attributed to a total of 1.2 dichloromethane solvent molecules per unit cell ( 0.6 molecules per asymmetric unit). A similar two position disorder to that observed in the $\alpha$ form is present also in the $\beta$ form. In this case the occupancy factor ratio is $70 / 30 \%$. Furthermore, there is two-position disorder (65\% and $35 \%$ occupancy factors) of the naphthalene $\mathrm{C}$ methyl group which points towards the 1,4naphthalene ring. 


\section{Prismarene conformations}

As all the crystalline forms of prism[5]arene, $\mathbf{1}$ and 1,4-confused-prism[5]arene, $\mathbf{2}$ are racemic mixtures, to compare the conformations of the prismarene the same $\mathrm{S}$ entiomer has been investigated. In Figure S82 the prismarene conformation of all crystallographically independent S enantiomers are viewed orthogonally with respect to the mean plane defined by the five methylene bridges. The dihedral angles, $\theta$ between the mean plane of the bridging methylene groups and the mean planes of the 5 naphthalene rings are reported in Table S5. The dihedral angles reported indicate the outward $\left(>90^{\circ}\right)$ or inward $\left(<90^{\circ}\right)$ tilt of the mean plane of the naphthalene moities, viewed from the top as in Figure 83. Intramolecular distances, $d$, between methylene bridge and the baricenter of the opposite naphthalene ring for the crystalline forms of prism[5] arene $\mathbf{1}$ and 1,4-C-prism[5] arene 2 are reported in Table S6. The naphthalene rings are labeled as in Figure S82 starting from the ring, $\mathbf{A}$ through which the twofold or pseudo-twofold axis passes, followed by the adjacent rings $\mathbf{B}$ and $\mathbf{B}$ ' and the opposite rings $\mathbf{C}$ and $\mathbf{C}$ '.

In comparison with the $\alpha$ and $\beta$ forms, the $\gamma$ form of prism[5]arene, 1 shows a more open conformation of the prismarene macrocycle. In the $\gamma$ form, the prism[5] arene molecules lie on a crystallographic twofold axis which passes through a naphthalene aromatic ring (A) and a bridging methylene group on the opposite side. As indicated by the dihedral angles, $\theta$ (Table S5), $\mathbf{A}$ is orthogonal $\left(90^{\circ}\right)$, and the adjacent $\mathbf{B}$ and $\mathbf{B}$ ' rings are slightly tilted, with complementary angles, towards the centre of the cycle ( $9.7^{\circ}$ tilt from orthogonality), while $\mathbf{C}$ and $\mathbf{C}^{\prime}$ are significantly tilted (ca. $30^{\circ}$ in opposite directions, Table S5). As clear from Figure S82 and indicated by the intramolecular distances, $d$ (Table S6) the conformation of the prismarene in $\gamma$ is more close to a regular pentagon with respect to the $\alpha$ and $\beta$ forms. The overall results in a rather open prismarene ring with a hole in the centre of molecules. The $\alpha$ and $\beta$ forms are more distorted with respect to the $\gamma$ form, with partial loss of the twofold axis. The naphthalene moieties $\mathbf{C}$ and $\mathbf{C}^{\prime}$ are much more inclined towards the center of the macroring in the $\alpha$ and $\beta$ forms. In particular naphthalene 3 is tilted by more than $40^{\circ}$. The overall result is that the hole observed for the $\gamma$ form is closed in one side by one of the methoxy groups of $\mathbf{C}$, leading to the formation of a cavity.

A similar analysis is presented for the two pseudo-polymorphic forms 1,4-C-prism[5] arene. For these structures, $\mathbf{A}$ is also defined as the naphthalene moiety on the pseudo-twofold axis and it therefore corresponds to the 1,4-bridged naphthalene. In this case all three crystallographic independent molecules show very similar conformations. The most significant observation in all cases is the very acute angle which $\mathbf{A}$ makes with the mean plane of the prismarene macrocycles. In fact, the 1,4bridged naphthalene lies almost flat into the centre of the macrocycle, thereby completely filling the cavity. 
Table S3: Crystal data and structure refinement for the three crystalline forms of prism[5]arene 1

\begin{tabular}{|c|c|c|c|}
\hline \multicolumn{4}{|c|}{1} \\
\hline & $\alpha$ form & $\beta$ form & $\gamma$ form \\
\hline Empirical formula & $\begin{array}{l}\left(\mathrm{C}_{65} \mathrm{H}_{60} \mathrm{O}_{10}\right) \\
3\left(\mathrm{CH}_{2} \mathrm{Cl}_{2}\right)\end{array}$ & $\begin{array}{l}\left(\mathrm{C}_{65} \mathrm{H}_{60} \mathrm{O}_{10}\right) \\
1.9\left(\mathrm{CH}_{2} \mathrm{Cl}_{2}\right)\end{array}$ & $\left(\mathrm{C}_{65} \mathrm{H}_{60} \mathrm{O}_{10}\right),\left(\mathrm{CH}_{2} \mathrm{Cl}_{2}\right)$ \\
\hline Formula weight & 1255.91 & 1162.49 & 1086.06 \\
\hline Temperature (K) & $100(2)$ & $100(2)$ & $100(2)$ \\
\hline Wavelength (Å) & 0.7 & 0.7 & 0.7 \\
\hline Crystal system & Triclinic & Triclinic & Monoclinic \\
\hline \multirow[t]{2}{*}{ Space group } & $P-1$ & $P-1$ & $\mathrm{C} 2 / \mathrm{c}$ \\
\hline & $a=13.171(3)$ & $a=10.3230(15)$ & $a=26.397(2)$ \\
\hline \multirow{5}{*}{$\begin{array}{l}\text { Unit cell dimensions } \\
\left(\AA \AA^{\circ}\right)\end{array}$} & $\alpha=76.093(7)$ & $\alpha=107.381(3)$ & $\alpha=90$ \\
\hline & $b=13.4040(13)$ & $b=13.7720(8)$ & $b=12.1790(3)$ \\
\hline & $B=80.772(6)$ & $B=86.09(1)$ & $B=96.210(1)$ \\
\hline & $c=17.6730(11)$ & $c=21.1170(6)$ & $c=16.2740(6)$ \\
\hline & $y=88.492(4)$ & $\gamma=99.769(10)$ & $y=90$ \\
\hline Volume $\left(\AA^{3}\right)$ & $2989.2(7)$ & $2823.5(5)$ & $5201.2(9)$ \\
\hline $\mathrm{z}$ & 2 & 2 & 4 \\
\hline$\rho_{\text {calcd }}\left(\mathrm{g} / \mathrm{cm}^{3}\right)$ & 1.395 & 1.367 & 1.387 \\
\hline$\mu\left(\mathrm{mm}^{-1}\right)$ & 0.330 & 0.249 & 0.188 \\
\hline$F(000)$ & 1312 & 1220 & 2288 \\
\hline Reflections collected & 47654 & 53515 & 49253 \\
\hline $\begin{array}{l}\text { Independent } \\
\text { reflections }\end{array}$ & $\begin{array}{l}23371 \\
{[R(\text { int })=0.0169]}\end{array}$ & $\begin{array}{l}15564 \\
{[R(\text { int })=0.0184]}\end{array}$ & $\begin{array}{l}7601 \\
{[R(\text { int })=0.0468]}\end{array}$ \\
\hline $\begin{array}{l}\text { Data / restraints / } \\
\text { parameters }\end{array}$ & 13771 / 0 / 768 & 15564 / 0 / 765 & 7601 / 0 / 372 \\
\hline GooF & 1.052 & 1.023 & 1.026 \\
\hline $\mathrm{R}_{1} / \mathrm{wR}_{2}[\mathrm{I}>2 \sigma(\mathrm{I})]$ & $0.0436 / 0.1143$ & 0.044 / 0.1164 & $0.0528 / 0.1324$ \\
\hline $\mathrm{R}_{1} / \mathrm{wR} 2$ all data & $0.0468 / 0.1149$ & 0.0492 / 0.1209 & 0.0729 / 0.1477 \\
\hline $\begin{array}{l}\text { Largest. Diff. } \\
\text { peak/hole }\left(e \AA^{-3}\right)\end{array}$ & $0.872 /-0.962$ & $0.674 /-0.607$ & $0.849 /-0.543$ \\
\hline CCDC code & 1950823 & 1950824 & 1950825 \\
\hline
\end{tabular}


Table S4: Crystal data and structure refinement for the two crystalline forms of

\section{1,4-C-Prism[5] arene 2}

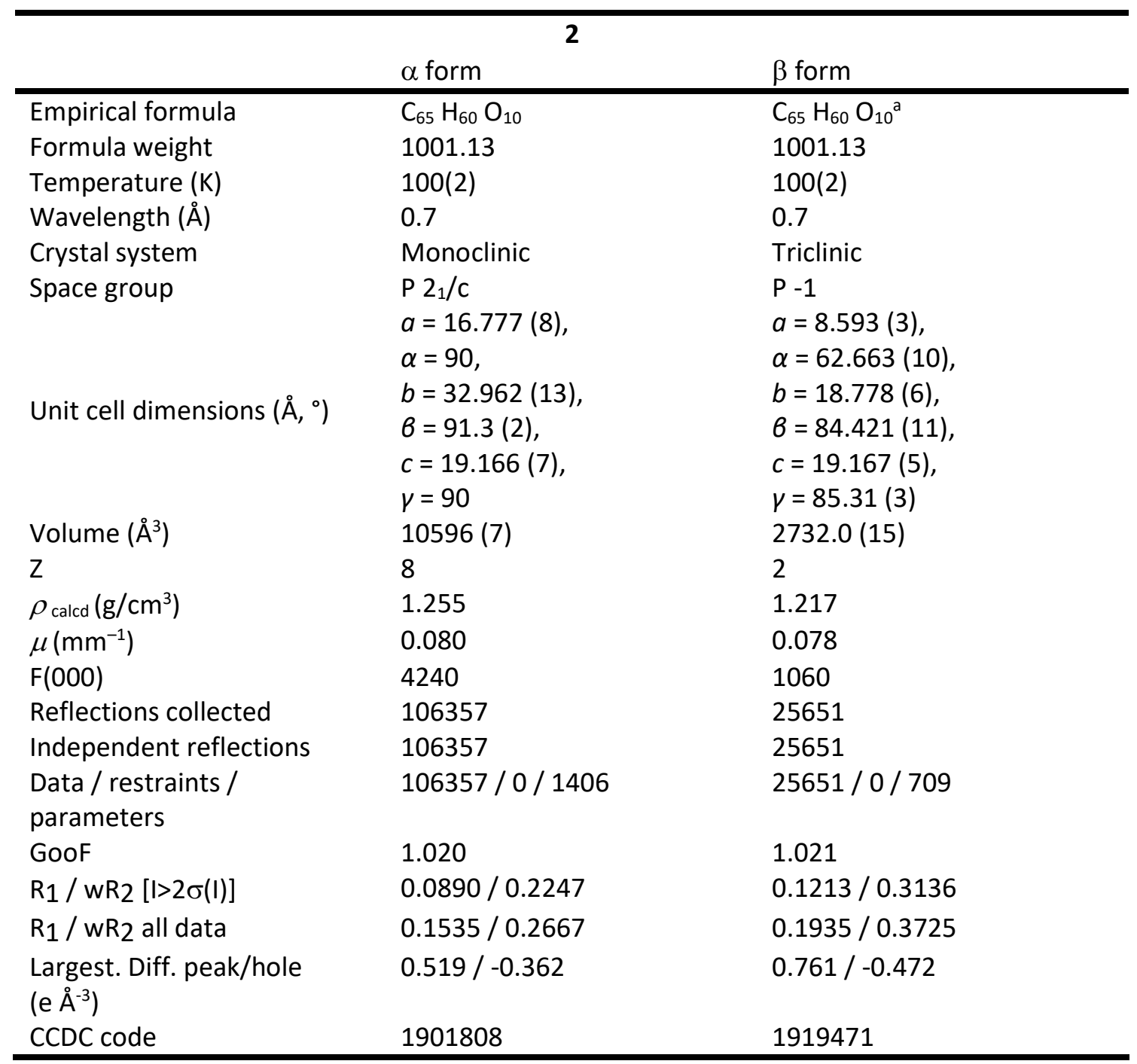

a The cell also contained ca. 1.2 severely disordered dichloromethane solvent molecules with partial cccupation, which were accounted for using the Platon squeeze tool. 
Table S5: Dihedreal angles, $\theta$, between the mean plane of the bridging methylene groups and the mean planes of the 5 naphthalene rings for the crystalline forms of prism[5]arene 1 and 1,4-Cprism[5]arene 2

\begin{tabular}{cccccc}
\hline Crystalline & \multicolumn{5}{c}{ Dihedreal angles, $\theta\left[^{\circ}\right]$} \\
\cline { 2 - 6 } Form & A & B & \multicolumn{5}{c}{$\mathrm{B}^{\prime}$} & $\mathrm{C}$ & $\mathrm{C}^{\prime}$ \\
\hline \multicolumn{5}{c}{ Prism[5]arene, 1 } \\
\hline$\alpha$ & 95.7 & 63.9 & 108.1 & 132.3 & 56.3 \\
$\beta$ & 94.6 & 65.1 & 109.7 & 132.0 & 53.7 \\
$\gamma$ & 90.0 & 99.7 & 80.3 & 60.3 & 119.7 \\
\hline \multicolumn{5}{c}{ 1,4-C-prism[5]arene, 2 } \\
\hline$\alpha^{\text {a }}$ & 37.7 & 101.0 & 77.5 & 49.9 & 129.4 \\
& 37.4 & 103.3 & 78.3 & 49.6 & 128.6 \\
$\beta$ & 28.5 & 103.7 & 78.0 & 51.0 & 126.7 \\
\hline
\end{tabular}

a There are 2 independent molecules in the asymmetric unit. See text and Figure S82 for the designation of the 5 naphthalene moieties A, B, B', C and C'.

Table S6. Intramolecular distances, $d$, between methylene bridge and the baricenter of the opposite naphthalene ring for the crystalline forms of prism[5] arene $\mathbf{1}$ and 1,4-C-prism[5] arene 2.

\begin{tabular}{cccccc}
\hline Crystalline & \multicolumn{5}{c}{ Intramolecular distances, $d[\AA]$} \\
\cline { 2 - 6 } Form & A & B & $B^{\prime}$ & $C$ & $C^{\prime}$ \\
\hline \multicolumn{5}{c}{ Prism[5]arene, 1 } \\
\hline$\alpha$ & 11.27 & 8.82 & 8.53 & 10.12 & 10.64 \\
$\beta$ & 11.21 & 8.93 & 8.49 & 10.04 & 10.67 \\
$\gamma$ & 8.93 & 10.77 & 10.77 & 9.72 & 9.72 \\
\hline \multicolumn{6}{c}{ 1,4-C-prism[5]arene, 2 } \\
\hline$\alpha^{\text {a }}$ & 9.16 & 10.20 & 10.11 & 8.55 & 8.60 \\
& 9.29 & 10.03 & 10.06 & 8.56 & 8.65 \\
$\beta$ & 9.41 & 10.38 & 10.38 & 8.87 & 8.90 \\
\hline
\end{tabular}

a There are 2 independent molecules in the asymmetric unit.

See text and Figure S82 for the designation of the 5 naphthalene moieties A, B, B', C and C'. 

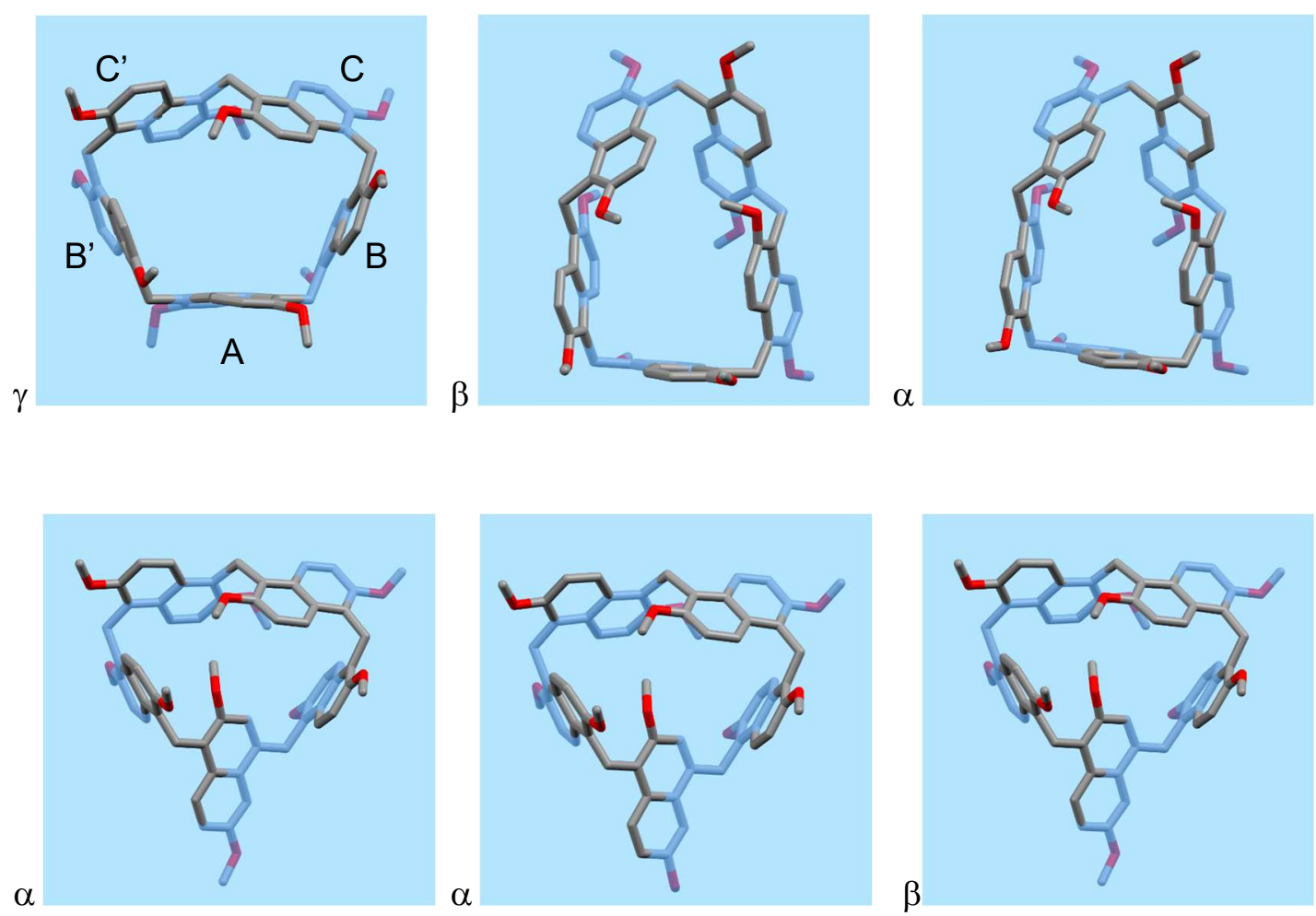

Figure S76: Prismarene conformation of all crystallographically independent $\mathrm{S}$ enantiomers of prism[5]arene, 1 (top row) and 1,4-C-prism[5]arene, 2 (bottom row), viewed orthogonally with respect to the mean plane defined by the five methylene bridges. Hydrogen atoms, solvent molecules and disordered groups are omitted for clarity. The naphthalene ring labeling scheme of the top left pannel is applied to all molecules.

a

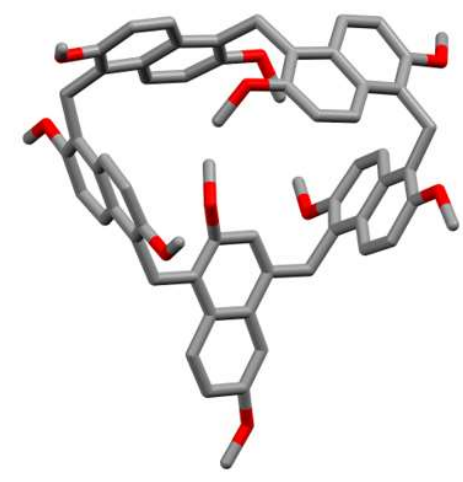

b

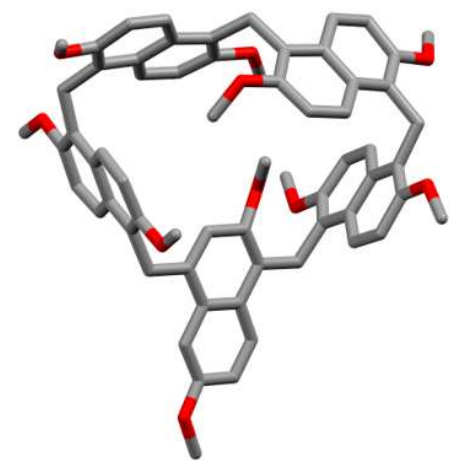

C

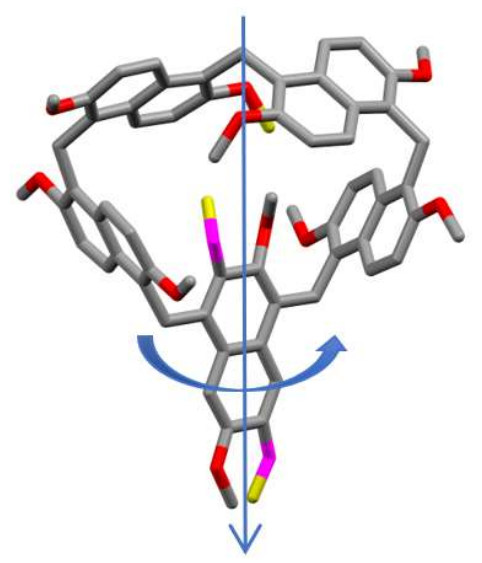

Figure S77: Two position disorder observed in both crystal forms of 1,4-C-prism[5]arene, 2. The molecules of 1,4-C-prism[5] arene oriented as (a) and $180^{\circ}$ rotated around the pseudo-two-fold axis (b) are overlapped in the crystal structures with an observed occupational disorder of only two methoxy groups of the 1,4-naphthalene ring (c). Hydrogen atoms are omitted for clarity. 


\section{Equilibrium geometries (Cartesian coordinates, $\AA$ ) and electronic energies}

(Hartree, include nuclear repulsion)

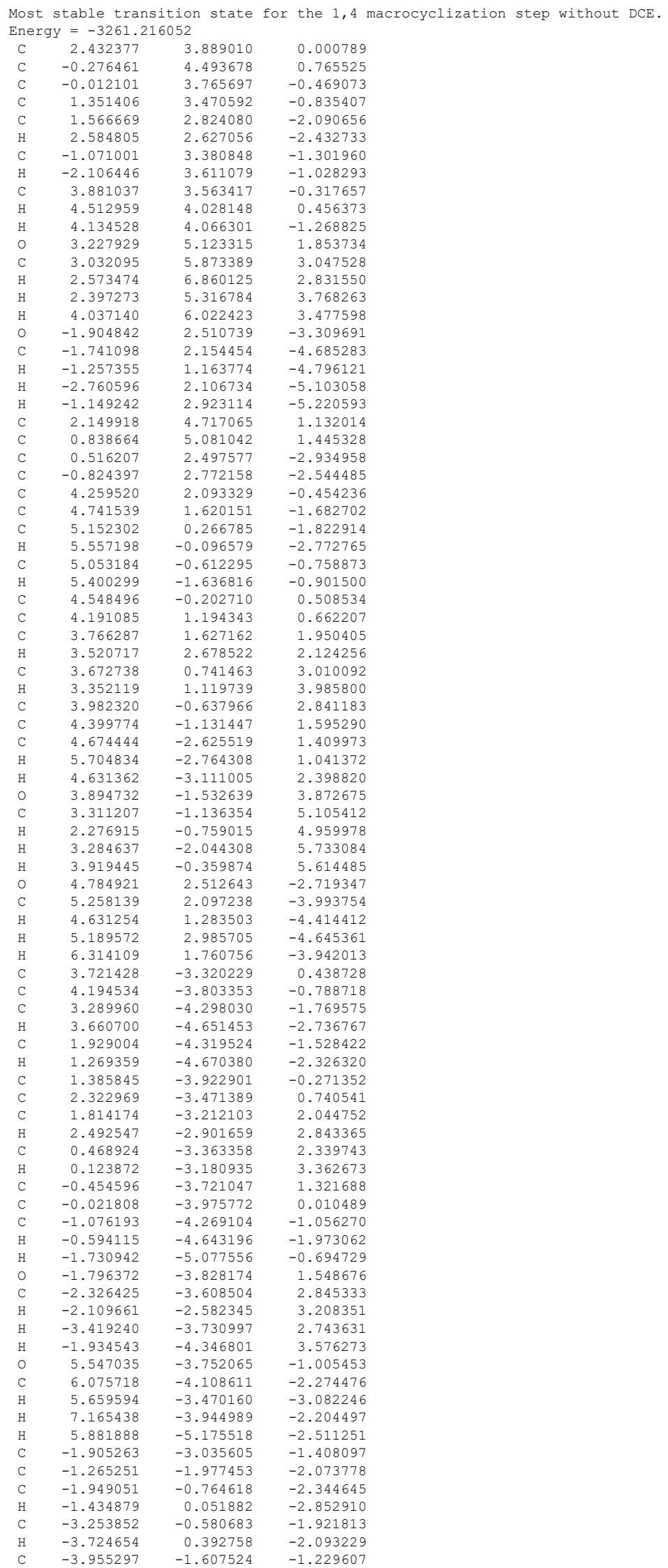




\begin{tabular}{rrr}
-3.279729 & -2.875985 & -1.030460 \\
-4.020035 & -3.909710 & -0.382699 \\
-3.577332 & -4.901119 & -0.255275 \\
-5.287924 & -3.693782 & 0.123029 \\
-5.810799 & -4.522543 & 0.610471 \\
-5.879684 & -2.398462 & 0.063396 \\
-5.225596 & -1.355233 & -0.603736 \\
-5.807958 & 0.038027 & -0.534578 \\
-5.907838 & 0.450946 & -1.560865 \\
-6.845418 & -0.030218 & -0.168039 \\
-7.069791 & -2.108016 & 0.667709 \\
-7.754271 & -3.114237 & 1.397924 \\
-8.052417 & -3.963133 & 0.747115 \\
-7.139211 & -3.497410 & 2.239706 \\
-8.662145 & -2.631583 & 1.801108 \\
0.035204 & -2.184296 & -2.427679 \\
0.794502 & -1.151198 & -3.029931 \\
0.824090 & -0.239857 & -2.399477 \\
1.818861 & -1.552040 & -3.130194 \\
0.399193 & -0.888437 & -4.034382 \\
-5.089675 & 1.125946 & 0.275387 \\
-5.720795 & 2.393141 & 0.270843 \\
-5.091748 & 3.527702 & 0.838831 \\
-5.596920 & 4.498391 & 0.849847 \\
-3.791988 & 3.439534 & 1.327859 \\
-3.306935 & 4.353251 & 1.689538 \\
-3.088874 & 2.213198 & 1.304878 \\
-3.800121 & 1.025857 & 0.882489 \\
-3.113460 & -0.221704 & 1.084331 \\
-3.677578 & -1.151826 & 1.114993 \\
-1.742466 & -0.283069 & 1.224115 \\
-1.242239 & -1.254066 & 1.263328 \\
-0.995239 & 0.919646 & 1.299285 \\
-1.671781 & 2.134861 & 1.602571 \\
-0.892936 & 3.213721 & 2.143966 \\
0.079603 & 2.908615 & 2.546592 \\
-1.421567 & 3.939241 & 2.776231 \\
0.332736 & 0.979253 & 1.162312 \\
1.040133 & -0.166747 & 0.666376 \\
1.975381 & 0.224219 & 0.243416 \\
1.262713 & -0.868258 & 1.487323 \\
0.455370 & -0.680702 & -0.116477 \\
-6.937312 & 2.446458 & -0.336130 \\
-7.631311 & 3.683684 & -0.425115 \\
-7.044673 & 4.436815 & -0.991732 \\
-8.568361 & 3.466359 & -0.966873 \\
-7.874455 & 4.085952 & 0.580376 \\
0.630462 & 5.739789 & 2.294406 \\
0.734719 & 2.040390 & -3.904957 \\
-1.210092 & 5.073572 & 0.770573 \\
& & \\
\hline & &
\end{tabular}

Most stable transition state for the 1,5 macrocyclization step without DCE. Energy $=-3261.221317$

$\begin{array}{rrrr}\text { C } & 1.688615 & -2.530204 & 2.208131 \\ \text { C } & -0.436518 & -2.007651 & 0.411943 \\ \text { C } & -0.556258 & -1.693309 & 1.794264 \\ \text { C } & 0.518839 & -1.958466 & 2.679634 \\ \text { H } & 2.499403 & -2.701754 & 2.920650 \\ \text { H } & 0.445341 & -1.696388 & 3.739206 \\ \text { C } & 1.837687 & -2.954382 & 0.853063 \\ \text { C } & 0.724442 & -2.752817 & -0.037507 \\ \text { C } & 0.806022 & -3.316145 & -1.335768 \\ \text { C } & 1.919172 & -4.050336 & -1.726722 \\ \text { C } & 3.041141 & -4.188496 & -0.867359 \\ \text { C } & 3.042203 & -3.582535 & 0.401357 \\ \text { H } & -0.030305 & -3.225300 & -2.036583 \\ \text { H } & 1.926280 & -4.505348 & -2.722159 \\ \text { C } & 4.329604 & -3.456866 & 1.211943 \\ \text { H } & 4.212714 & -3.888790 & 2.219763 \\ \text { H } & 5.124540 & -4.034971 & 0.712282 \\ \text { O } & 4.165575 & -4.870119 & -1.228809 \\ \text { O } & -1.703737 & -1.114210 & 2.195335 \\ \text { C } & 4.316737 & -5.322066 & -2.569373 \\ \text { H } & 3.559819 & -6.091400 & -2.826917 \\ \text { H } & 4.248058 & -4.477196 & -3.286352 \\ \text { H } & 5.323796 & -5.770377 & -2.624709 \\ \text { C } & -2.018261 & -1.071538 & 3.584777 \\ \text { H } & -3.051322 & -0.697193 & 3.645377 \\ \text { H } & -1.966242 & -2.086885 & 4.025127 \\ \text { H } & -1.343048 & -0.388425 & 4.135808 \\ \text { C } & -4.934606 & -1.206252 & -1.523305 \\ \text { C } & -2.862034 & -2.977780 & -0.827196 \\ \text { C } & -3.120700 & -2.659471 & -2.208209 \\ \text { C } & -4.141527 & -1.740124 & -2.534386 \\ \text { H } & -5.742521 & -0.531956 & -1.816659 \\ \text { H } & -4.335668 & -1.454871 & -3.572516 \\ \text { C } & -3.859495 & -2.612895 & 0.170367 \\ \text { C } & -4.802732 & -1.578147 & -0.146622 \\ \text { C } & -5.595120 & -0.978146 & 0.876446 \\ \text { C } & -5.569465 & -1.560234 & 2.160776 \\ \text { C } & -4.742422 & -2.681223 & 2.430943 \\ \text { C } & -3.867275 & -3.167429 & 1.461477 \\ \text { H } & -4.736914 & -3.137203 & 3.425437 \\ \text { H } & -3.169847 & -3.976915 & 1.710618 \\ \text { O } & -2.295723 & -3.225101 & -3.091282 \\ & & & \end{array}$




\begin{tabular}{|c|c|c|}
\hline-6.335416 & -0.960661 & 3.112453 \\
\hline-6.380652 & 0.299885 & 0.615175 \\
\hline-6.756050 & 0.677873 & 1.581883 \\
\hline-7.275336 & 0.073547 & 0.007862 \\
\hline-3.943434 & 3.174194 & -1.570233 \\
\hline-5.163849 & 2.763948 & -2.075946 \\
\hline-5.975700 & 1.847816 & -1.351166 \\
\hline-5.565565 & 1.372803 & -0.098085 \\
\hline-3.334133 & 3.845779 & -2.180397 \\
\hline-5.483319 & 3.135852 & -3.054514 \\
\hline-3.469297 & 2.737827 & -0.298036 \\
\hline-4.338735 & 1.860916 & 0.463998 \\
\hline-3.935569 & 1.501346 & 1.781698 \\
\hline-2.723795 & 1.923739 & 2.299336 \\
\hline-1.835210 & 2.700545 & 1.514300 \\
\hline-2.189125 & 3.125522 & 0.226266 \\
\hline-4.601614 & 0.909586 & 2.415787 \\
\hline-2.458001 & 1.669990 & 3.328900 \\
\hline-7.143548 & 1.341035 & -1.854205 \\
\hline-0.625796 & 3.117118 & 1.986055 \\
\hline-0.937751 & 4.860576 & 0.093017 \\
\hline-1.675727 & 4.405368 & -1.437698 \\
\hline-1.193944 & 3.992779 & -0.536436 \\
\hline 2.399630 & 2.028581 & -2.05011 \\
\hline 0.083966 & 3.283818 & -0.979292 \\
\hline-0.015108 & 2.337993 & -2.011327 \\
\hline 1.146127 & 1.728321 & -2.556397 \\
\hline 3.271875 & 1.572368 & -2.51987 \\
\hline 1.066513 & 1.027372 & -3.39393 \\
\hline 1.381108 & 3.580832 & -0.43515 \\
\hline 2.569225 & 2.926098 & -0.95667 \\
\hline 3.866127 & 3.186233 & -0.39338 \\
\hline 3.970684 & 4.101386 & 0.663470 \\
\hline 2.818834 & 4.774846 & 1.155398 \\
\hline 1.569840 & 4.523653 & 0.61744 \\
\hline 2.905354 & 5.499013 & 1.97163 \\
\hline 0.711967 & 5.048159 & 1.043570 \\
\hline-1.273510 & 2.078466 & -2.47504 \\
\hline 5.217538 & 4.301355 & 1.19679 \\
\hline 5.134937 & 2.540552 & -0.94289 \\
\hline 5.987650 & 2.920440 & -0.35417 \\
\hline 5.290700 & 2.899056 & -1.975393 \\
\hline 5.186661 & -1.816022 & -1.10538 \\
\hline 5.400354 & -1.063931 & -2.24732 \\
\hline 5.376270 & 0.355340 & -2.18964 \\
\hline 5.186181 & 1.019860 & -0.967641 \\
\hline 5.218515 & -2.903882 & -1.18884 \\
\hline 5.578041 & -1.581332 & -3.195658 \\
\hline 5.044906 & 0.240724 & 0.22793 \\
\hline 4.976644 & -1.202846 & 0.16211 \\
\hline 4.711656 & -1.982414 & 1.33882 \\
\hline 4.685257 & -1.337578 & 2.58217 \\
\hline 4.834017 & 0.077029 & 2.66416 \\
\hline 4.977635 & 0.843113 & 1.519376 \\
\hline 4.821363 & 0.578845 & 3.637094 \\
\hline 5.076613 & 1.927218 & 1.62251 \\
\hline 5.506460 & 1.134870 & -3.30785 \\
\hline 4.490601 & -2.121318 & 3.69021 \\
\hline-7.584186 & 1.731203 & -3.14808 \\
\hline-6.845418 & 1.455818 & -3.92973 \\
\hline-8.525340 & 1.181792 & -3.32516 \\
\hline-7.782191 & 2.821938 & -3.19628 \\
\hline-6.336727 & -1.462289 & 4.44413 \\
\hline-7.010703 & -0.7999994 & 5.01426 \\
\hline-6.723273 & -2.501481 & 4.48240 \\
\hline-5.321852 & -1.427796 & 4.8917 \\
\hline-2.368967 & -2.879693 & -4.48384 \\
\hline-1.566267 & -3.455995 & -4.97182 \\
\hline-3.350988 & -3.170606 & -4.90296 \\
\hline-2.196932 & -1.795850 & -4.62541 \\
\hline 0.031393 & 2.372639 & 2.99918 \\
\hline 0.057628 & 1.292948 & 2.74407 \\
\hline 1.064704 & 2.762111 & 3.03744 \\
\hline-0.445219 & 2.508189 & 3.99334 \\
\hline-1.467143 & 1.171797 & -3.5430 \\
\hline-2.560717 & 1.092384 & -3.67726 \\
\hline-1.003320 & 1.538582 & -4.48364 \\
\hline-1.056514 & 0.167350 & -3.30844 \\
\hline 4.274424 & -1.509497 & 4.95394 \\
\hline 4.071728 & -2.334408 & 5.65953 \\
\hline 5.170488 & -0.951015 & 5.29585 \\
\hline 3.401181 & -0.823627 & 4.92699 \\
\hline 5.602559 & 0.525948 & -4.58573 \\
\hline 5.649734 & 1.354939 & -5.3138 \\
\hline 6.521329 & -0.090738 & -4.67700 \\
\hline 4.714437 & -0.103973 & -4.80477 \\
\hline 5.377435 & 5.154224 & 2.3191 \\
\hline 6.451158 & 5.119780 & 2.57555 \\
\hline 5.093549 & 6.200978 & 2.08152 \\
\hline 4.782293 & 4.801255 & 3.18794 \\
\hline-2.252728 & -3.872180 & -0.645121 \\
\hline-1.428005 & -1.534657 & -0.51670 \\
\hline-2.096356 & -0.738751 & -0.16500 \\
\hline-1.084153 & -1.404411 & -1.54906 \\
\hline
\end{tabular}


Most stable transition state for the 1,4 macrocyclization step, DCE inside the cavity. Energy $=-4259.921879$

\begin{tabular}{|c|c|c|c|}
\hline & -1.618735 & -3.242040 & -2.304502 \\
\hline & 0.957559 & -2.639637 & -1.318639 \\
\hline & 0.615966 & -2.368457 & -2.670324 \\
\hline & -0.665816 & -2.719301 & -3.163563 \\
\hline & -2.619629 & -3.434101 & -2.700070 \\
\hline & -0.937034 & -2.530100 & -4.206299 \\
\hline & -1.330721 & -3.555604 & -0.941270 \\
\hline & 0.025666 & -3.380537 & -0.493122 \\
\hline & 0.369431 & -3.863793 & 0.792503 \\
\hline & -0.586208 & -4.438981 & 1.617948 \\
\hline & -1.948558 & -4.494595 & 1.220341 \\
\hline & -2.346864 & -4.017450 & -0.043574 \\
\hline & 1.399240 & -3.789704 & 1.158156 \\
\hline & -0.278996 & -4.817728 & 2.597243 \\
\hline & -3.825839 & -3.922043 & -0.408444 \\
\hline & -4.022097 & -4.490737 & -1.332732 \\
\hline & -4.410716 & -4.411136 & 0.387817 \\
\hline & -2.924336 & -4.984684 & 2.036889 \\
\hline & 1.547005 & -1.729869 & -3.407169 \\
\hline & -2.635398 & -5.229331 & 3.409616 \\
\hline & -1.926620 & -6.074146 & 3.530856 \\
\hline & -2.221498 & -4.321572 & 3.896578 \\
\hline & -3.599164 & -5.493806 & 3.877914 \\
\hline & 1.250601 & -1.349126 & -4.751926 \\
\hline & 2.121058 & -0.769110 & -5.098538 \\
\hline & 1.115313 & -2.242116 & -5.393620 \\
\hline & 0.343451 & -0.715893 & -4.794035 \\
\hline & 5.643981 & -0.549837 & 1.363501 \\
\hline & 4.294092 & -3.004961 & 1.606429 \\
\hline C & 4.788329 & -2.358459 & 2.753298 \\
\hline & 5.471439 & -1.114081 & 2.616373 \\
\hline & 6.203289 & 0.386132 & 1.287058 \\
\hline H & 5.879516 & -0.599413 & 3.491689 \\
\hline C & 4.463450 & -2.440918 & 0.335592 \\
\hline & 5.152244 & -1.183993 & 0.180850 \\
\hline $\bar{C}$ & 5.356202 & -0.634962 & -1.121452 \\
\hline$C$ & 5.049839 & -1.434316 & -2.268291 \\
\hline 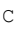 & 4.319925 & -2.615713 & -2.132810 \\
\hline 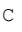 & 3.828129 & -3.016550 & -0.846296 \\
\hline$H$ & 3.995131 & -3.180067 & -3.010910 \\
\hline$H$ & 3.443838 & -4.040866 & -0.754710 \\
\hline 0 & 4.584181 & -2.983331 & 3.926548 \\
\hline 0 & 5.448313 & -0.929979 & -3.465333 \\
\hline$C$ & 5.890353 & 0.770943 & -1.315682 \\
\hline $\mathrm{H}$ & 5.994309 & 0.959150 & -2.396711 \\
\hline H & 6.906975 & 0.830176 & -0.887777 \\
\hline C & 3.507428 & 3.912977 & 0.554184 \\
\hline C & 4.814797 & 3.688236 & 0.945811 \\
\hline$C$ & 5.590164 & 2.662919 & 0.336876 \\
\hline C & 5.040035 & 1.866101 & -0.674226 \\
\hline $\mathrm{H}$ & 2.944469 & 4.696259 & 1.065139 \\
\hline $\mathrm{H}$ & 5.243630 & 4.310780 & 1.737246 \\
\hline $\mathrm{C}$ & 2.885605 & 3.149809 & -0.478493 \\
\hline $\mathrm{C}$ & 3.694565 & 2.119484 & -1.111385 \\
\hline C & 3.121880 & 1.402832 & -2.199584 \\
\hline C & 1.836568 & 1.666806 & -2.638064 \\
\hline $\mathrm{C}$ & 1.045445 & 2.662173 & -2.008989 \\
\hline C & 1.540049 & 3.402249 & -0.921167 \\
\hline H & 3.705612 & 0.652599 & -2.737784 \\
\hline H & 1.440624 & 1.112461 & -3.491296 \\
\hline 0 & 6.880303 & 2.395667 & 0.711114 \\
\hline 0 & -0.199385 & 2.984242 & -2.448163 \\
\hline $\mathrm{H}$ & 0.242515 & 5.085085 & -1.165341 \\
\hline $\mathrm{H}$ & 1.252443 & 5.184020 & 0.275013 \\
\hline C & 0.643380 & 4.491765 & -0.327292 \\
\hline C & -2.541603 & 2.939702 & 2.236157 \\
\hline C & -0.511164 & 3.986828 & 0.538999 \\
\hline C & -0.222653 & 3.562052 & 1.845548 \\
\hline C & -1.249774 & 3.091419 & 2.706300 \\
\hline $\mathrm{H}$ & -3.297797 & 2.528701 & 2.908824 \\
\hline H & -1.020678 & 2.806313 & 3.737314 \\
\hline C & -1.874025 & 3.919219 & 0.080990 \\
\hline $\mathrm{C}$ & -2.893827 & 3.294953 & 0.903493 \\
\hline C & -4.213237 & 3.047745 & 0.386880 \\
\hline C & -4.553922 & 3.587008 & -0.860760 \\
\hline C & -3.594635 & 4.311313 & -1.622380 \\
\hline C & -2.293793 & 4.448674 & -1.173869 \\
\hline H & -3.869844 & 4.751629 & -2.586049 \\
\hline $\mathrm{H}$ & -1.581604 & 4.976697 & -1.811608 \\
\hline 0 & 1.080594 & 3.644060 & 2.241613 \\
\hline 0 & -5.834362 & 3.381920 & -1.306423 \\
\hline C & -5.232988 & 2.216430 & 1.163916 \\
\hline $\mathrm{H}$ & -6.197200 & 2.276899 & 0.631834 \\
\hline H & -5.397121 & 2.668988 & 2.156200 \\
\hline C & -4.137538 & -1.968656 & 1.823637 \\
\hline $\mathrm{C}$ & -4.254094 & -1.089160 & 2.884618 \\
\hline C & -4.623035 & 0.266434 & 2.669810 \\
\hline C & -4.867682 & 0.745659 & 1.372947 \\
\hline H & -3.866232 & -3.004121 & 2.037319 \\
\hline H & -4.056408 & -1.455770 & 3.895935 \\
\hline C & -4.796114 & -0.181936 & 0.274539 \\
\hline C & -4.401217 & -1.561363 & 0.485242 \\
\hline C & -4.319569 & -2.487550 & -0.611032 \\
\hline C & -4.715867 & -2.053734 & -1.884063 \\
\hline
\end{tabular}




\begin{tabular}{lrrr}
$\mathrm{C}$ & -5.115223 & -0.705375 & \multicolumn{1}{l}{-2.097185} \\
$\mathrm{C}$ & -5.137725 & 0.202861 & -1.053241 \\
$\mathrm{H}$ & -5.413768 & -0.367638 & \multicolumn{1}{c}{-3.094778} \\
$\mathrm{H}$ & -5.461386 & 1.225387 & -1.259614 \\
$\mathrm{O}$ & -4.763043 & 1.151482 & 3.705372 \\
$\mathrm{O}$ & -4.707050 & -2.981100 & -2.894647 \\
$\mathrm{C}$ & 7.487397 & 3.150458 & 1.751633 \\
$\mathrm{H}$ & 6.936331 & 3.038764 & 2.708697 \\
$\mathrm{H}$ & 8.506177 & 2.740905 & 1.866193 \\
$\mathrm{H}$ & 7.552246 & 4.225747 & 1.485851 \\
$\mathrm{C}$ & 5.276042 & -1.712706 & -4.642587 \\
$\mathrm{H}$ & 5.720930 & -1.124607 & -5.463091 \\
$\mathrm{H}$ & 5.803405 & -2.684434 & -4.550153 \\
$\mathrm{H}$ & 4.204318 & -1.893303 & -4.856280 \\
$\mathrm{C}$ & 5.050506 & -2.392586 & 5.141607 \\
$\mathrm{H}$ & 4.756709 & -3.089553 & 5.944503 \\
$\mathrm{H}$ & 6.153192 & -2.280572 & 5.132366 \\
$\mathrm{H}$ & 4.573288 & -1.406651 & 5.312297 \\
$\mathrm{C}$ & -0.740662 & 2.368972 & -3.602987 \\
$\mathrm{H}$ & -0.837133 & 1.272912 & -3.473422 \\
$\mathrm{H}$ & -1.748359 & 2.803803 & -3.726386 \\
$\mathrm{H}$ & -0.127145 & 2.585223 & -4.503351 \\
$\mathrm{C}$ & 1.503127 & 2.987375 & 3.426557 \\
$\mathrm{H}$ & 2.606224 & 3.052113 & 3.428005 \\
$\mathrm{H}$ & 1.107386 & 3.485190 & 4.337193 \\
$\mathrm{H}$ & 1.193820 & 1.921721 & 3.427372 \\
$\mathrm{C}$ & -4.996939 & -2.578883 & -4.225309 \\
$\mathrm{H}$ & -4.887619 & -3.485569 & -4.846036 \\
$\mathrm{H}$ & -6.034656 & -2.196603 & -4.318575 \\
$\mathrm{H}$ & -4.285328 & -1.803119 & -4.579036 \\
$\mathrm{C}$ & -4.359021 & 0.774593 & 5.014539 \\
$\mathrm{H}$ & -4.484435 & 1.675742 & 5.640311 \\
$\mathrm{H}$ & -4.995953 & -0.039813 & 5.418835 \\
$\mathrm{H}$ & -3.296322 & 0.457006 & 5.031073 \\
$\mathrm{C}$ & -6.201867 & 3.792264 & -2.614316 \\
$\mathrm{H}$ & -7.247121 & 3.463657 & -2.752364 \\
$\mathrm{H}$ & -6.150139 & 4.895555 & -2.726048 \\
$\mathrm{H}$ & -5.561717 & 3.314423 & -3.385939 \\
$\mathrm{C}$ & -0.802393 & -0.853931 & 1.456822 \\
$\mathrm{H}$ & 0.222282 & -1.112940 & 1.156497 \\
$\mathrm{Cl}$ & -0.733528 & -0.533315 & 3.247210 \\
$\mathrm{H}$ & -1.468900 & -1.718650 & 1.323631 \\
$\mathrm{C}$ & -1.316778 & 0.362851 & 0.720349 \\
$\mathrm{H}$ & -2.331908 & 0.633210 & 1.039004 \\
$\mathrm{H}$ & -0.645209 & 1.229004 & 0.813165 \\
$\mathrm{Cl}$ & -1.424988 & -0.021077 & -1.047409 \\
$\mathrm{H}$ & 3.777506 & -3.964616 & 1.726721 \\
$\mathrm{C}$ & 2.110867 & -2.004232 & -0.736941 \\
$\mathrm{H}$ & 2.449123 & -1.086461 & -1.235168 \\
$\mathrm{H}$ & 2.084952 & -1.913798 & 0.354021 \\
& & &
\end{tabular}

Most stable transition state for the 1,5 macrocyclization step, DCE inside the cavity. Energy $=-4259.928701$

$\begin{array}{rrrr}\text { C } & 2.194551 & 1.866851 & -1.755524 \\ \text { C } & 4.663795 & 0.530201 & -1.315809 \\ \text { C } & 3.635508 & -0.060816 & -2.105158 \\ \text { C } & 2.400521 & 0.614089 & -2.300073 \\ \text { H } & 1.225112 & 2.345691 & -1.922608 \\ \text { H } & 1.594529 & 0.145203 & -2.870499 \\ \text { C } & 3.195710 & 2.541482 & -0.989963 \\ \text { C } & 4.436930 & 1.845362 & -0.742667 \\ \text { C } & 5.416846 & 2.518723 & 0.023550 \\ \text { C } & 5.208998 & 3.807258 & 0.501916 \\ \text { C } & 4.001930 & 4.496845 & 0.229824 \\ \text { C } & 2.980016 & 3.865907 & -0.505659 \\ \text { H } & 6.373124 & 2.043070 & 0.250430 \\ \text { H } & 6.003286 & 4.284306 & 1.084124 \\ \text { C } & 1.695379 & 4.613129 & -0.809118 \\ \text { H } & 1.842945 & 5.670124 & -0.523611 \\ \text { H } & 1.554663 & 4.614404 & -1.902040 \\ \text { O } & 3.763962 & 5.763629 & 0.651636 \\ \text { O } & 3.910543 & -1.240925 & -2.686884 \\ \text { C } & 4.697696 & 6.415592 & 1.500629 \\ \text { H } & 4.850912 & 5.846860 & 2.441556 \\ \text { H } & 5.675047 & 6.565635 & 0.995866 \\ \text { H } & 4.256067 & 7.399440 & 1.736551 \\ \text { C } & 3.142613 & -1.647993 & -3.823572 \\ \text { H } & 2.097378 & -1.853551 & -3.538983 \\ \text { H } & 3.182628 & -0.868924 & -4.610948 \\ \text { H } & 3.617204 & -2.574347 & -4.185892 \\ \text { C } & 3.392749 & -1.161936 & 1.369888 \\ \text { C } & 6.032473 & -1.404409 & 0.443707 \\ \text { C } & 5.711927 & -0.458088 & 1.476442 \\ \text { C } & 4.351760 & -0.263394 & 1.812201 \\ \text { H } & 2.350780 & -0.970405 & 1.650722 \\ \text { H } & 4.084666 & 0.582353 & 2.452825 \\ \text { C } & 5.080340 & -2.487859 & 0.192426 \\ \text { C } & 3.727804 & -2.372232 & 0.663529 \\ \text { C } & 2.822184 & -3.464592 & 0.522799 \\ \text { C } & 3.293906 & -4.651678 & -0.084218 \\ \text { C } & 4.601902 & -4.733857 & -0.607768 \\ \text { C } & 5.480446 & -3.655656 & -0.473775 \\ \text { H } & 4.951736 & -5.648679 & -1.096113 \\ \text { H } & 6.506268 & -3.741818 & -0.855155 \\ \text { O } & 6.601785 & 0.329620 & 2.079790 \\ \text { } & & & \end{array}$




\begin{tabular}{|c|c|c|}
\hline 2.408587 & -5.680082 & -0.116966 \\
\hline 1.447932 & -3.486619 & 1.154131 \\
\hline 1.397050 & -4.425236 & 1.741932 \\
\hline 1.371942 & -2.675199 & 1.898302 \\
\hline-2.256106 & -3.318122 & -1.175427 \\
\hline-1.039702 & -3.301965 & -1.822734 \\
\hline 0.182561 & -3.361917 & -1.097106 \\
\hline 0.187973 & -3.434789 & 0.295261 \\
\hline-3.170908 & -3.285634 & -1.769616 \\
\hline-1.002119 & -3.233966 & -2.916237 \\
\hline-2.326757 & -3.407549 & 0.246926 \\
\hline-1.082318 & -3.488638 & 0.981796 \\
\hline-1.167235 & -3.643095 & 2.394423 \\
\hline-2.388167 & -3.742895 & 3.040572 \\
\hline-3.603244 & -3.639026 & 2.313088 \\
\hline-3.588574 & -3.418015 & 0.927025 \\
\hline-0.260616 & -3.699079 & 3.003608 \\
\hline-2.401580 & -3.883796 & 4.125763 \\
\hline 1.366413 & -3.354899 & -1.795359 \\
\hline-4.827626 & -3.712455 & 2.918990 \\
\hline-5.730284 & -3.285467 & 0.874846 \\
\hline-5.023791 & -3.890933 & -0.626744 \\
\hline-4.888735 & -3.146077 & 0.175416 \\
\hline-4.889447 & 0.828383 & -1.640155 \\
\hline-4.954260 & -1.752082 & -0.444903 \\
\hline-5.042496 & -1.598691 & -1.835426 \\
\hline-5.011410 & -0.304974 & -2.424770 \\
\hline-4.861882 & 1.802845 & -2.132639 \\
\hline-5.072844 & -0.189534 & -3.511676 \\
\hline-4.903967 & -0.574028 & 0.373995 \\
\hline-4.831050 & 0.744757 & -0.220101 \\
\hline-4.728513 & 1.918435 & 0.602899 \\
\hline-4.788754 & 1.767051 & 1.997088 \\
\hline-4.895652 & 0.478249 & 2.585015 \\
\hline-4.945535 & -0.655251 & 1.794859 \\
\hline-4.952048 & 0.367192 & 3.672442 \\
\hline-5.058423 & -1.622929 & 2.286105 \\
\hline-5.140614 & -2.741910 & -2.585480 \\
\hline-4.742585 & 2.906878 & 2.757539 \\
\hline-4.603914 & 3.313313 & -0.003886 \\
\hline-4.716480 & 4.046203 & 0.813315 \\
\hline-5.449961 & 3.482236 & -0.690889 \\
\hline-0.959824 & 4.303623 & -2.207350 \\
\hline-2.184264 & 4.247732 & -2.851061 \\
\hline-3.367884 & 3.929717 & -2.132790 \\
\hline-3.315312 & 3.629193 & -0.762331 \\
\hline-0.080911 & 4.564556 & -2.805885 \\
\hline-2.226736 & 4.461175 & -3.923652 \\
\hline-2.046651 & 3.691659 & -0.095264 \\
\hline-0.834905 & 4.040386 & -0.814029 \\
\hline 0.428530 & 4.116595 & -0.119349 \\
\hline 0.459197 & 3.826549 & 1.246469 \\
\hline-0.724868 & 3.492530 & 1.953610 \\
\hline-1.942372 & 3.447481 & 1.306512 \\
\hline-0.666573 & 3.309553 & 3.032714 \\
\hline-2.839934 & 3.249737 & 1.892107 \\
\hline-4.597127 & 3.899007 & -2.732401 \\
\hline 1.642080 & 3.950886 & 1.936153 \\
\hline 1.500392 & -4.360053 & -2.799653 \\
\hline 1.060276 & -4.039193 & -3.766896 \\
\hline 2.584256 & -4.527438 & -2.936799 \\
\hline 1.022212 & -5.304175 & -2.475252 \\
\hline 2.816827 & -6.948891 & -0.613553 \\
\hline 1.943457 & -7.613210 & -0.496343 \\
\hline 3.092824 & -6.893630 & -1.686435 \\
\hline 3.671345 & -7.352136 & -0.031748 \\
\hline 8.012116 & 0.100873 & 1.927409 \\
\hline 8.499486 & 0.812191 & 2.613591 \\
\hline 8.268887 & -0.937538 & 2.212026 \\
\hline 8.338827 & 0.304666 & 0.890560 \\
\hline-4.912724 & -3.791258 & 4.335034 \\
\hline-4.430695 & -2.916052 & 4.819255 \\
\hline-5.990824 & -3.793093 & 4.573194 \\
\hline-4.452636 & -4.725584 & 4.718861 \\
\hline-5.092089 & -2.661655 & -4.001976 \\
\hline-5.135534 & -3.703277 & -4.366186 \\
\hline-5.957582 & -2.097779 & -4.408462 \\
\hline-4.148993 & -2.189629 & -4.349915 \\
\hline 2.128133 & 2.759818 & 2.544864 \\
\hline 3.132691 & 2.996960 & 2.939075 \\
\hline 1.477220 & 2.417441 & 3.376416 \\
\hline 2.206725 & 1.946799 & 1.793830 \\
\hline-4.709698 & 4.103256 & -4.133200 \\
\hline-5.783218 & 3.996554 & -4.368435 \\
\hline-4.370999 & 5.119351 & -4.424763 \\
\hline-4.132189 & 3.344314 & -4.701637 \\
\hline-4.544040 & 2.806993 & 4.160883 \\
\hline-4.422436 & 3.842769 & 4.523938 \\
\hline-5.417896 & 2.345408 & 4.666195 \\
\hline-3.629638 & 2.222571 & 4.396712 \\
\hline-0.444761 & 0.332897 & -0.153819 \\
\hline 0.321411 & -0.456481 & -0.228619 \\
\hline-1.236721 & 0.436684 & -1.784881 \\
\hline 0.026941 & 1.311532 & 0.031894 \\
\hline-1.492950 & 0.008233 & 0.891582 \\
\hline-2.254603 & 0.798867 & 0.974836 \\
\hline
\end{tabular}




$\begin{array}{lrrr}\text { H } & -1.971197 & -0.966018 & 0.714126 \\ \mathrm{C} 1 & -0.672764 & -0.099707 & 2.514608 \\ \mathrm{C} & 5.915848 & -0.163486 & -1.180150 \\ \mathrm{H} & 6.093248 & -0.975307 & -1.895133 \\ \mathrm{H} & 6.806663 & 0.436523 & -0.960141 \\ \mathrm{H} & 7.085726 & -1.672526 & 0.300157\end{array}$

Minimum energy conformer of 1,4 product with DCE inside the cavity Energy $=-4263.379155$

Minimum energy conformer of 1,4 product with
Energy $=-4263.379155$
$\begin{array}{lrrr}\text { C } & -2.527010 & -3.741173 & 0.251287 \\ \text { C } & 0.285544 & -3.985207 & 0.823860 \\ C & -0.138545 & -3.551286 & -0.473570\end{array}$

$\begin{array}{lrrr}\text { C } & 0.285544 & -3.985207 & 0.823860 \\ \text { C } & -0.138545 & -3.551286 & -0.473570\end{array}$

$\begin{array}{llll}\text { C } & -0.138545 & -3.551286 & -0.473570 \\ \text { C } & -1.551034 & -3.506604 & -0.768688\end{array}$

$\begin{array}{llll}\text { C } & -1.551034 & -3.506604 & -0.768688 \\ \text { C } & -1.927015 & -3.243755 & -2.111265\end{array}$

H $\quad-2.971929-3.284170 \quad-2.383567$

$\begin{array}{llll}C & 0.779904 & -3.200060 & -1.489919\end{array}$

$\begin{array}{llll}\mathrm{H} & 1.837490 & -3.155536 & -1.27789 \\ \mathrm{C} & -4.020294 & -3.605744 & -0.032273\end{array}$

$\begin{array}{lllr}\mathrm{C} & -4.020294 & -3.605744 & -0.032273 \\ \mathrm{H} & -4.571941 & -3.963944 & 0.839677\end{array}$

$\begin{array}{llll}\mathrm{H} & -4.288680 & -4.267098 & -0.859608\end{array}$

$\begin{array}{llll}0 & -3.008145 & -4.397495 & 2.475393\end{array}$

$\begin{array}{llll}\text { C } & -2.581553 & -4.498133 & 3.840202\end{array}$

$\begin{array}{llll}\mathrm{H} & -1.984225 & -5.402481 & 4.009736 \\ \mathrm{H} & -2.005283 & -3.614236 & 4.140591\end{array}$

$\begin{array}{llll}\mathrm{H} & -3.499143 & -4.557363 & 4.428692\end{array}$

$\begin{array}{llll}\mathrm{O} & 1.348512 & -2.510746 & -3.657205 \\ \mathrm{C} & 0.946563 & -2.089720 & -4.964944\end{array}$

H $\quad 0.255808 \quad-1.238463 \quad-4.914190$

$\begin{array}{llll}\mathrm{H} & 1.864127 & -1.784566 & -5.471390\end{array}$

$\begin{array}{llll}\mathrm{H} & 0.476121 & -2.908596 & -5.524720\end{array}$

$\begin{array}{llll}\text { C } & -2.063014 & -4.117795 & 1.508415\end{array}$

$\begin{array}{lllr}\text { C } & -1.078559 & -4.255244 & 1.773277 \\ \text { C } & -1.008220 & -2.946948 & -3.095558\end{array}$

$\begin{array}{llll}\text { C } & 0.363931 & -2.875780 & -2.768530\end{array}$

$\begin{array}{llll}\text { C } & -4.471862 & -2.191155 & -0.378215 \\ \text { C } & -4.924699 & -1.877581 & -1.658195\end{array}$

C $\quad-5.232449 \quad-0.543507 \quad-2.01355$

$\begin{array}{llll}\mathrm{H} & -5.561805 & -0.308797 & -3.019768\end{array}$

$\begin{array}{llll}\text { C } & -5.118345 & 0.474652 & -1.094868\end{array}$

$\begin{array}{llll}\mathrm{H} & -5.356803 & 1.483700 & -1.404079\end{array}$

$\begin{array}{rrrr}\text { C } & -4.745922 & 0.213540 & 0.247200 \\ \text { C } & -4.456866 & -1.152857 & 0.606024\end{array}$

C $\quad-4.190146 \quad-1.431909 \quad 1.969708$

$\begin{array}{llll}\mathrm{H} & -3.969538 & -2.444563 & 2.280626 \\ \mathrm{C} & -4.227834 & -0.440192 & 2.921947\end{array}$

$\mathrm{H} \quad-4.044094 \quad-0.699319 \quad 3.958424$

$\begin{array}{llll}\text { C } & -4.489233 & 0.901473 & 2.558742\end{array}$

$\begin{array}{lll}-4.691030 & 1.257061 & 1.225652\end{array}$

$\begin{array}{lll}-5.832512 & 2.824034 & 0.301378\end{array}$

$\begin{array}{lll}-4.969245 & 3.313394 & 1.740599\end{array}$

$\begin{array}{lll}-4.555184 & 1.908702 & 3.498349\end{array}$

$\begin{array}{lll}-4.107510 & 1.632204 & 4.831855\end{array}$

$\begin{array}{lll}-3.077097 & 1.255185 & 4.833051\end{array}$

$\begin{array}{lll}-4.149370 & 2.588223 & 5.356657\end{array}$

$\begin{array}{lll}-4.765280 & 0.912278 & 5.334060\end{array}$

$\begin{array}{lll}-5.064759 & -2.918933 & -2.552073\end{array}$

$\begin{array}{lll}-4.506797 & -1.958567 & -4.329630\end{array}$

$\begin{array}{lll}-5.270215 & -3.571635 & -4.452353\end{array}$

$\begin{array}{lll}-6.273958 & -2.142077 & -4.082446\end{array}$

$\begin{array}{lll}-3.777475 & 3.301622 & -0.046800\end{array}$

$\begin{array}{lll}-4.056245 & 3.745158 & -1.336526\end{array}$

$\begin{array}{lll}-3.029371 & 4.263509 & -2.160904\end{array}$

$\begin{array}{lll}-3.256303 & 4.602224 & -3.165783\end{array}$

$\begin{array}{lll}-1.731517 & 4.340313 & -1.710156\end{array}$

$\begin{array}{lll}-0.974720 & 4.710377 & -2.388542 \\ -1.373361 & 3.929319 & -0.400566\end{array}$

$\begin{array}{lll}-1.373361 & 3.929319 & -0.400566\end{array}$

$\begin{array}{lll}-2.441305 & 3.444821 & 0.446593\end{array}$

$\begin{array}{lll}-2.129654 & 3.136528 & 1.792952\end{array}$

$\begin{array}{lll}-2.913808 & 2.832553 & 2.470786\end{array}$

$\begin{array}{lll}-0.849119 & 3.251234 & 2.275363\end{array}$

$\begin{array}{lll}0.649897 & 3.017696 & 3.314712\end{array}$

$\begin{array}{lll}-0.028255 & 4.002518 & 0.094946\end{array}$

$\begin{array}{lll}1.154158 & 4.451301 & -0.765134\end{array}$

$\begin{array}{lll}0.786815 & 4.942136 & -1.66670\end{array}$

$\begin{array}{lll}1.715741 & 5.206168 & -0.211703\end{array}$

$\begin{array}{lll}1.480450 & 3.811478 & 1.900478 \\ 1.868583 & 3.077612 & 3.068764 \\ 1.576977 & 2.025161 & 2.983047\end{array}$

$\begin{array}{lll}1.576977 & 2.025161 & 2.983047\end{array}$

$\begin{array}{lll}2.956653 & 3.156124 & 3.109182\end{array}$

$.435659-3.510766-3.97$
$.365132-3.665231$

$\begin{array}{lll}-5.365132 & 3.665231 & -1.765662\end{array}$

$\begin{array}{lll}-5.647929 & 3.895156 & -3.150783\end{array}$

$\begin{array}{lll}-5.060708 & 3.225426 & -3.792029\end{array}$

$\begin{array}{lll}-6.710916 & 3.678401 & -3.271189\end{array}$

$\begin{array}{lll}-5.455812 & 4.937828 & -3.432961\end{array}$

$\begin{array}{lll}2.077693 & 3.307887 & -1.170066 \\ 1.710947 & 2.492102 & -2.241527\end{array}$

$\begin{array}{lll}1.710947 & 2.492102 & -2.241527\end{array}$

$\begin{array}{lll}2.150322 & 0.695980 & -3.383282\end{array}$

$\begin{array}{lll}3.599283 & 1.021192 & -1.862547\end{array}$

$\begin{array}{lll}4.135555 & 0.119495 & -2.126670 \\ 4.071716 & 1.842814 & -0.808130\end{array}$

$\begin{array}{lll}4.071716 & 1.842814 & -0.808130 \\ 3.314209 & 3.035035 & -0.500305\end{array}$ 


\begin{tabular}{|c|c|c|c|}
\hline C & 3.877752 & 3.932393 & 0.442349 \\
\hline H & 3.376487 & 4.863223 & 0.669628 \\
\hline C & 5.046784 & 3.645805 & 1.106655 \\
\hline $\mathrm{H}$ & 5.439555 & 4.368230 & 1.813591 \\
\hline C & 5.725712 & 2.426984 & 0.873769 \\
\hline C & 5.257743 & 1.520337 & -0.074884 \\
\hline C & 6.065247 & 0.259882 & -0.337003 \\
\hline H & 6.628414 & 0.398746 & -1.264623 \\
\hline H & 6.815548 & 0.175751 & 0.454802 \\
\hline 0 & 6.868827 & 2.081304 & 1.564505 \\
\hline C & 7.310878 & 2.934785 & 2.624447 \\
\hline H & 7.612776 & 3.920376 & 2.247591 \\
\hline H & 6.534347 & 3.057452 & 3.390619 \\
\hline H & 8.177183 & 2.434113 & 3.060791 \\
\hline 0 & 0.595325 & 2.865183 & -2.944800 \\
\hline C & 0.269531 & 2.164504 & -4.147055 \\
\hline H & 0.040689 & 1.112335 & -3.947438 \\
\hline H & -0.623303 & 2.658173 & -4.535561 \\
\hline H & 1.082909 & 2.236304 & -4.881111 \\
\hline C & 5.328364 & -1.062429 & -0.438196 \\
\hline C & 5.584443 & -1.898130 & -1.524448 \\
\hline C & 4.943050 & -3.151895 & -1.637321 \\
\hline H & 5.173796 & -3.815921 & -2.462567 \\
\hline $\mathrm{C}$ & 4.010542 & -3.545912 & -0.705892 \\
\hline H & 3.542674 & -4.514853 & -0.836586 \\
\hline C & 3.667745 & -2.727144 & 0.402118 \\
\hline C & 4.403311 & -1.494124 & 0.561520 \\
\hline C & 4.185036 & -0.747582 & 1.747603 \\
\hline H & 4.726754 & 0.176768 & 1.905280 \\
\hline C & 3.303109 & -1.176678 & 2.714229 \\
\hline H & 3.183087 & -0.590635 & 3.618604 \\
\hline C & 2.543762 & -2.354667 & 2.522445 \\
\hline C & 2.661162 & -3.098692 & 1.349211 \\
\hline C & 1.746121 & -4.293508 & 1.151760 \\
\hline H & 1.751002 & -4.886818 & 2.071615 \\
\hline H & 2.137483 & -4.943024 & 0.365485 \\
\hline 0 & 1.665776 & -2.831768 & 3.462946 \\
\hline C & 1.661740 & -2.232255 & 4.761255 \\
\hline H & 1.345868 & -1.183197 & 4.723029 \\
\hline H & 0.936200 & -2.803256 & 5.343583 \\
\hline H & 2.650862 & -2.300613 & 5.232325 \\
\hline 0 & 6.474673 & -1.443265 & -2.472533 \\
\hline C & 6.634520 & -2.201631 & -3.676758 \\
\hline H & 5.675760 & -2.333403 & -4.194312 \\
\hline H & 7.310817 & -1.616467 & -4.302438 \\
\hline H & 7.082595 & -3.183342 & -3.476964 \\
\hline H & -0.353486 & -4.591467 & 2.750466 \\
\hline H & -1.356858 & -2.747918 & -4.103171 \\
\hline C & -1.196880 & -0.240232 & 1.074138 \\
\hline $\mathrm{Cl}$ & -0.371588 & -0.226219 & 2.709826 \\
\hline $\mathrm{H}$ & -2.037343 & 0.444206 & 1.159984 \\
\hline $\mathrm{H}$ & -1.542805 & -1.260191 & 0.922488 \\
\hline C & -0.224135 & 0.198081 & 0.007131 \\
\hline $\mathrm{Cl}$ & -1.168028 & 0.240385 & -1.559628 \\
\hline $\mathrm{H}$ & 0.591715 & -0.509640 & -0.139115 \\
\hline & 0.153787 & 1.207027 & 0.165680 \\
\hline
\end{tabular}

Minimum energy conformer of 1,5 product with DCE inside the cavity Energy $=-4263.374956$

$\begin{array}{rrrr}\text { Energy } & =-4263.3749 \\ \mathrm{O} & -1.276614 & -3.176772 & -2.532367 \\ \mathrm{O} & 4.825638 & -2.083647 & 3.396127 \\ \mathrm{O} & 4.909197 & 2.130721 & -3.129499 \\ \mathrm{O} & -1.636596 & 3.109217 & -2.327302 \\ \mathrm{O} & 4.815563 & -4.376813 & -1.703386 \\ \mathrm{O} & 4.722682 & 4.497786 & 1.906512 \\ \mathrm{O} & -1.225741 & 3.160034 & 2.544379 \\ \mathrm{O} & -7.117804 & 1.434522 & -2.212350 \\ \mathrm{O} & -1.631641 & -3.077275 & 2.421455 \\ \mathrm{O} & -7.084595 & -1.426714 & 2.317065 \\ \mathrm{C} & 4.800129 & -0.683148 & 0.004376 \\ \mathrm{C} & 4.756203 & -1.629968 & 1.074898 \\ \mathrm{C} & -4.550362 & 1.736131 & 0.399706 \\ \mathrm{C} & 4.757380 & 0.735743 & 0.264719 \\ \mathrm{C} & 4.745128 & 1.153751 & 1.618675 \\ \mathrm{H} & 4.742024 & 2.208620 & 1.857994 \\ \mathrm{C} & 4.787507 & -1.149019 & 2.382922 \\ \mathrm{C} & -2.568922 & -3.236702 & -0.561606 \\ \mathrm{C} & -4.196834 & -1.143541 & -1.567613 \\ \mathrm{H} & -4.781505 & -0.321784 & -1.960506 \\ \mathrm{C} & 4.706286 & -3.129026 & 0.801448 \\ \mathrm{H} & 5.577767 & -3.413192 & 0.206974 \\ \mathrm{H} & 4.801551 & -3.652764 & 1.755746 \\ \mathrm{C} & 3.473983 & 4.362334 & 1.335813 \\ \mathrm{C} & -0.401475 & 3.250825 & -1.750965 \\ \mathrm{C} & 4.746421 & 1.678992 & -0.811391 \\ \mathrm{C} & -3.766543 & 2.855183 & -0.073449 \\ \mathrm{C} & 2.124474 & 3.578569 & -0.520973 \\ \mathrm{C} & 3.553858 & -4.241578 & -1.163209 \\ \mathrm{C} & 2.163640 & -3.529851 & 0.692839 \\ \mathrm{C} & -3.096939 & 1.607376 & 2.351356 \\ \mathrm{H} & -2.857705 & 1.145294 & 3.302354 \\ \mathrm{C} & -2.328800 & -2.667818 & -1.812439 \\ \mathrm{C} & -4.539403 & -1.716326 & -0.316898 \\ \mathrm{C} & 4.873108 & 1.198310 & -2.114622 \\ \mathrm{C} & 3.401205 & 3.699771 & 0.113505 \\ \mathrm{C} & -2.591894 & 3.272287 & 0.632130 \\ & & & \end{array}$




\begin{tabular}{|c|c|c|}
\hline-3.735669 & -2.819306 & 0.158747 \\
\hline-5.657310 & 1.242867 & -0.360925 \\
\hline-0.359396 & 3.869182 & -0.500197 \\
\hline-2.300951 & 2.663969 & 1.853521 \\
\hline 1.072026 & 4.710337 & 1.370241 \\
\hline 0.203347 & 5.078550 & 1.898802 \\
\hline-1.665194 & 4.366715 & 0.116918 \\
\hline-2.185020 & 4.962033 & -0.636042 \\
\hline-1.441947 & 5.048144 & 0.938719 \\
\hline 0.918049 & 4.052111 & 0.122747 \\
\hline 4.914371 & -1.100470 & -1.345112 \\
\hline 4.985212 & -2.153659 & -1.580990 \\
\hline 2.003515 & 2.996481 & -1.805740 \\
\hline 2.888718 & 2.686477 & -2.342182 \\
\hline 0.967947 & -3.958114 & -0.002939 \\
\hline-0.323674 & -3.792938 & 0.599598 \\
\hline 4.669308 & 3.178645 & -0.552967 \\
\hline 5.521088 & 3.469408 & 0.066655 \\
\hline 4.796531 & 3.693056 & -1.508754 \\
\hline 4.777329 & 0.240437 & 2.647939 \\
\hline 4.793243 & 0.601268 & 3.670499 \\
\hline-6.044520 & 1.936017 & -1.505106 \\
\hline-3.138825 & -1.619632 & -2.307641 \\
\hline-2.926440 & -1.176498 & -3.274301 \\
\hline-5.343028 & 3.091492 & -1.922546 \\
\hline-5.666367 & 3.640995 & -2.799513 \\
\hline-5.643439 & -1.229577 & 0.451578 \\
\hline 1.148122 & -4.550273 & -1.279738 \\
\hline 0.287522 & -4.869057 & -1.851612 \\
\hline 4.959599 & -0.188854 & -2.373738 \\
\hline 5.057781 & -0.549034 & -3.391412 \\
\hline 2.306666 & 4.865945 & 1.957201 \\
\hline 2.374172 & 5.378612 & 2.910405 \\
\hline 2.396763 & -4.695864 & -1.839094 \\
\hline 2.482537 & -5.156243 & -2.817097 \\
\hline-1.614674 & -4.305560 & -0.043267 \\
\hline-2.127391 & -4.923002 & 0.697493 \\
\hline-1.362699 & -4.970140 & -0.870518 \\
\hline 0.777872 & 2.840399 & -2.408686 \\
\hline 0.724997 & 2.389048 & -3.392228 \\
\hline 2.018552 & -3.015111 & 2.003163 \\
\hline 2.893023 & -2.748681 & 2.578308 \\
\hline 3.456172 & -3.633104 & 0.085552 \\
\hline-6.013656 & -1.921311 & 1.602334 \\
\hline-4.178353 & 1.148263 & 1.634652 \\
\hline-4.753576 & 0.322075 & 2.031311 \\
\hline-6.434813 & 0.002070 & 0.045670 \\
\hline-7.096295 & -0.262748 & -0.784856 \\
\hline-7.098455 & 0.260136 & 0.876572 \\
\hline-4.235620 & 3.525666 & -1.232804 \\
\hline-3.707185 & 4.390893 & -1.609533 \\
\hline 0.780566 & -2.857864 & 2.574998 \\
\hline 0.706990 & -2.452872 & 3.577926 \\
\hline-5.298007 & -3.068910 & 2.017417 \\
\hline-5.611377 & -3.621566 & 2.896026 \\
\hline-0.387244 & -3.217577 & 1.869804 \\
\hline-4.188753 & -3.491003 & 1.323142 \\
\hline-3.649034 & -4.350492 & 1.696224 \\
\hline-1.201192 & -2.883080 & -3.930395 \\
\hline-1.001534 & -1.821220 & -4.109585 \\
\hline-0.359932 & -3.469108 & -4.305140 \\
\hline-2.123291 & -3.182202 & -4.445278 \\
\hline 4.935860 & -4.798968 & -3.066867 \\
\hline 4.379503 & -4.133179 & -3.738849 \\
\hline 6.001534 & -4.743473 & -3.295993 \\
\hline 4.588688 & -5.831163 & -3.199960 \\
\hline 4.653204 & -1.639820 & 4.747222 \\
\hline 3.709642 & -1.092615 & 4.867874 \\
\hline 4.629284 & -2.548597 & 5.351081 \\
\hline 5.489717 & -1.008604 & 5.071732 \\
\hline 4.817155 & 5.017525 & 3.237284 \\
\hline 4.232076 & 4.414044 & 3.943099 \\
\hline 5.875544 & 4.960319 & 3.497797 \\
\hline 4.486927 & 6.062782 & 3.285095 \\
\hline-7.468917 & 2.056700 & -3.452486 \\
\hline-6.631214 & 2.038571 & -4.161731 \\
\hline-8.296436 & 1.466949 & -3.851168 \\
\hline-7.799948 & 3.092399 & -3.302923 \\
\hline-0.874419 & 2.573642 & 3.798484 \\
\hline-0.653168 & 1.505598 & 3.691156 \\
\hline 0.027028 & 3.098486 & 4.120243 \\
\hline-1.669028 & 2.713919 & 4.543192 \\
\hline-1.778097 & 2.257174 & -3.467558 \\
\hline-1.359838 & 1.262143 & -3.273911 \\
\hline-2.854313 & 2.176233 & -3.632079 \\
\hline-1.301904 & 2.689444 & -4.357308 \\
\hline 4.812590 & 1.672848 & -4.484088 \\
\hline 3.908952 & 1.069044 & -4.634458 \\
\hline 4.755592 & 2.576855 & -5.092882 \\
\hline 5.697111 & 1.092918 & -4.775251 \\
\hline-1.790545 & -2.245255 & 3.574060 \\
\hline-1.346316 & -1.257017 & 3.407662 \\
\hline-2.869410 & -2.145714 & 3.708368 \\
\hline-1.350492 & -2.704385 & 4.468907 \\
\hline-7.419420 & -2.047079 & 3.562715 \\
\hline & & \\
\hline
\end{tabular}




$\begin{array}{rrrr}\text { H } & -8.247251 & -1.461754 & 3.967189 \\ \mathrm{H} & -7.744526 & -3.085542 & 3.419765 \\ \mathrm{C} & 1.583006 & -0.377151 & -1.039050 \\ \mathrm{H} & 2.242800 & 0.486369 & -1.014472 \\ \mathrm{Cl} & 1.278331 & -0.718608 & -2.815294 \\ \mathrm{H} & 2.080359 & -1.258122 & -0.641867 \\ \mathrm{C} & 0.267705 & -0.099085 & -0.353116 \\ \mathrm{H} & -0.372451 & -0.978673 & -0.291344 \\ \mathrm{H} & -0.259860 & 0.742563 & -0.797288 \\ \mathrm{Cl} & 0.651447 & 0.399935 & 1.366240\end{array}$

Minimum energy conformer of 1,4 product without DCE

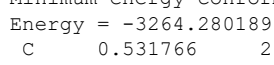
Energy $=-3264.280189$ 


$\begin{array}{rrr}-0.284382 & 9.661547 & 0.635750 \\ -1.009423 & 10.268524 & -0.880415 \\ 0.623897 & 9.543954 & -0.906182 \\ -5.105699 & -3.582460 & -0.514972 \\ 3.468040 & 1.812234 & 3.888704 \\ 2.356690 & 1.094763 & 4.458139 \\ 2.154563 & 1.555168 & 5.428287 \\ 2.605259 & 0.034883 & 4.602646 \\ 1.473780 & 1.174476 & 3.812269 \\ 1.002487 & 0.985817 & 1.093196 \\ 0.874056 & -0.139930 & 0.203513 \\ -0.118004 & -0.596928 & 0.281272 \\ 1.626891 & -0.863783 & 0.514172 \\ 1.070740 & 0.157744 & -0.830458 \\ -2.818912 & 2.008778 & -3.525970 \\ -2.925974 & 1.332181 & -4.783794 \\ -2.352770 & 1.936052 & -5.489282 \\ -3.969281 & 1.270710 & -5.118536 \\ -2.496137 & 0.324009 & -4.732869 \\ 5.033468 & 0.134285 & -3.548668 \\ 4.624200 & 0.822214 & -4.737290 \\ 4.968911 & 0.201098 & -5.565732 \\ 5.089231 & 1.813374 & -4.806592 \\ 3.532415 & 0.923050 & -4.782817 \\ -5.442159 & -0.197308 & 3.437417 \\ -5.233439 & 0.437010 & 4.704799 \\ -4.165957 & 0.606811 & 4.894454 \\ -5.630065 & -0.258076 & 5.446801 \\ -5.775488 & 1.388662 & 4.770909 \\ 0.737803 & -3.179840 & 2.087061 \\ 1.268632 & -2.317904 & 3.097677 \\ 0.857781 & -2.558234 & 4.087014 \\ 1.076108 & -1.265288 & 2.865171 \\ 2.345292 & -2.497409 & 3.093922 \\ -6.415470 & -3.422241 & -0.913954 \\ -6.884629 & -4.166675 & -2.043956 \\ -6.300569 & -3.937673 & -2.944598 \\ -7.919159 & -3.851550 & -2.190880 \\ -6.856460 & -5.246644 & -1.852133 \\ 6.475766 & -3.288397 & 0.580446 \\ -0.721418 & -3.167365 & -2.363139 \\ 6.982483 & -4.015257 & 1.706467 \\ 6.416742 & -3.783226 & 2.617802 \\ -0.015944 & -3.685198 & 1.824455 \\ 0.560175 & -5.306934 & -0.816820 \\ -1.963348 & -5.097179 & 1.525977 \\ -1.512348 & -1.966016 & -2.340655 \\ -1.607006 & -1.588553 & -1.316618 \\ -2.499855 & -2.244944 & -2.707993 \\ -1.086035 & -1.185133 & -2.982117 \\ & -5.286630 & 0.602025\end{array}$

Minimum energy conformer of 1,5 product without DCE Energy $=-3264,272065$

$\begin{array}{rrrr}\text { C } & 2.145279 & 2.152569 & -1.966570 \\ \text { C } & 2.581572 & 3.020522 & -0.975929 \\ \text { C } & 4.119459 & 0.766220 & -1.763100 \\ \text { C } & 3.849235 & 2.760019 & -0.354746 \\ \text { C } & 2.935406 & 1.061936 & -2.393661 \\ \text { C } & 4.591926 & 1.570239 & -0.691967 \\ \text { C } & 4.405896 & 3.611799 & 0.631572 \\ \text { H } & 2.589748 & 0.460929 & -3.229636 \\ \text { C } & 5.562213 & 3.284638 & 1.302262 \\ \text { H } & 3.904819 & 4.533052 & 0.899696 \\ \text { C } & 6.215985 & 2.055803 & 1.048687 \\ \text { C } & 5.733183 & 1.183711 & 0.074056 \\ \text { C } & 6.415613 & -0.150415 & -0.135208 \\ \text { H } & 7.195682 & -0.257488 & 0.624486 \\ \text { C } & 1.698842 & 4.197263 & -0.581755 \\ \text { H } & 1.446662 & 4.756195 & -1.483208 \\ \text { H } & 2.262640 & 4.883451 & 0.052641 \\ \text { C } & 6.095237 & -2.486309 & -0.923053 \\ \text { C } & 5.585708 & -1.432493 & -0.158831 \\ \text { C } & 4.171287 & -3.871090 & -0.439359 \\ \text { C } & 4.346828 & -1.628969 & 0.530531 \\ \text { C } & 5.394442 & -3.705445 & -1.047642 \\ \text { C } & 3.583844 & -2.845643 & 0.339091 \\ \text { C } & 3.799980 & -0.643624 & 1.399924 \\ \text { H } & 5.804370 & -4.516896 & -1.638153 \\ \text { H } & 3.644088 & -4.802501 & -0.601503 \\ \text { C } & 2.541279 & -0.782636 & 1.928007 \\ \text { H } & 4.375664 & 0.238093 & 1.642292 \\ \text { C } & 1.758176 & -1.922536 & 1.643522 \\ \text { C } & 2.261101 & -2.970786 & 0.888021 \\ \text { C } & 0.535233 & 3.318228 & 1.460240 \\ \text { C } & 0.427521 & 3.806658 & 0.157518 \\ \text { C } & -1.865650 & 3.073448 & 1.649180 \\ \text { C } & -0.876593 & 3.964355 & -0.409340 \\ \text { C } & -0.610654 & 2.957004 & 2.202654 \\ \text { C } & -2.051177 & 3.567925 & 0.334285 \\ \text { C } & -1.085089 & 4.528251 & -1.694706 \\ \text { H } & -0.513006 & 2.595213 & 3.220407 \\ \text { H } & -2.723404 & 2.810176 & 2.251915 \\ \text { C } & -2.347930 & 4.697129 & -2.212752 \\ & & & \end{array}$




\begin{tabular}{|c|c|c|}
\hline-0.238732 & 4.813510 & -2.305617 \\
\hline-2.457188 & 5.141573 & -3.195663 \\
\hline-3.489549 & 4.291616 & -1.481864 \\
\hline-3.359910 & 3.697524 & -0.229107 \\
\hline 1.387123 & -4.198899 & 0.668103 \\
\hline 1.129374 & -4.612300 & 1.643907 \\
\hline 1.950088 & -4.974782 & 0.148863 \\
\hline-4.596727 & 3.242786 & 0.533610 \\
\hline-5.477646 & 3.517832 & -0.051711 \\
\hline-4.660761 & 3.805517 & 1.468174 \\
\hline-4.754536 & 1.346786 & 2.197476 \\
\hline-4.677093 & 1.759252 & 0.868046 \\
\hline-4.859653 & -0.986193 & 1.543374 \\
\hline-4.730992 & 0.765276 & -0.158909 \\
\hline-4.846120 & -0.024898 & 2.528514 \\
\hline-4.794883 & -0.638552 & 0.170403 \\
\hline-4.765537 & 1.117587 & -1.531926 \\
\hline-4.917322 & -0.334541 & 3.565455 \\
\hline-4.846157 & 0.158696 & -2.516403 \\
\hline-4.761117 & 2.159019 & -1.822745 \\
\hline-4.890123 & 0.473584 & -3.553253 \\
\hline-4.880431 & -1.216070 & -2.185463 \\
\hline-4.832285 & -1.633601 & -0.856637 \\
\hline 0.124837 & -3.897299 & -0.122596 \\
\hline-2.136040 & -3.147243 & -1.660111 \\
\hline-1.191264 & -4.016752 & 0.434921 \\
\hline-0.875004 & -3.103057 & -2.204994 \\
\hline-2.343016 & -3.594823 & -0.326537 \\
\hline-1.421001 & -4.526407 & 1.736116 \\
\hline-0.736914 & -2.801292 & -3.240010 \\
\hline-2.983005 & -2.875006 & -2.274604 \\
\hline-2.691381 & -4.636123 & 2.253893 \\
\hline-0.588146 & -4.839625 & 2.353642 \\
\hline-2.821141 & -5.049940 & 3.247448 \\
\hline-3.811624 & -4.204031 & 1.507356 \\
\hline-3.654285 & -3.645675 & 0.239735 \\
\hline 2.136975 & -0.021070 & 2.587496 \\
\hline 7.320540 & 1.650367 & 1.762392 \\
\hline 7.786009 & 2.478457 & 2.833733 \\
\hline 8.124020 & 3.455934 & 2.466968 \\
\hline 8.631439 & 1.943250 & 3.269580 \\
\hline 7.009599 & 2.619972 & 3.596377 \\
\hline 0.250404 & -3.476204 & -1.438041 \\
\hline 1.802792 & 3.228560 & 1.974274 \\
\hline 1.974564 & 2.889970 & 3.350887 \\
\hline 1.565682 & 1.898362 & 3.580395 \\
\hline 1.505343 & 3.634616 & 4.006944 \\
\hline 3.054055 & 2.880769 & 3.512097 \\
\hline 0.932344 & 2.394113 & -2.592116 \\
\hline-0.059524 & 1.371727 & -2.368370 \\
\hline-0.988582 & 1.744681 & -2.803493 \\
\hline-0.201799 & 1.207299 & -1.293711 \\
\hline 0.222575 & 0.427550 & -2.849593 \\
\hline 7.300702 & -2.268670 & -1.550256 \\
\hline 7.801449 & -3.270156 & -2.443758 \\
\hline 8.721580 & -2.855670 & -2.859348 \\
\hline 7.091048 & -3.473324 & -3.255105 \\
\hline 8.030004 & -4.202790 & -1.912684 \\
\hline-4.767742 & 4.446139 & -1.976327 \\
\hline-4.933066 & 4.898488 & -3.324952 \\
\hline-4.559398 & 5.921969 & -3.454009 \\
\hline-6.008799 & 4.879845 & -3.508245 \\
\hline-4.428134 & 4.230020 & -4.034021 \\
\hline 0.490332 & -2.023083 & 2.194043 \\
\hline-0.455253 & -1.066179 & 1.671186 \\
\hline-0.150626 & -0.036266 & 1.892149 \\
\hline-1.410889 & -1.280380 & 2.153586 \\
\hline-0.560316 & -1.191129 & 0.587136 \\
\hline-5.095425 & -4.289574 & 2.000188 \\
\hline-5.284488 & -4.699754 & 3.359925 \\
\hline-4.957436 & -5.735312 & 3.515074 \\
\hline-6.358626 & -4.627549 & 3.538560 \\
\hline-4.751082 & -4.036646 & 4.052790 \\
\hline 1.506425 & -3.488597 & -2.019292 \\
\hline 1.976134 & -2.209466 & -2.474052 \\
\hline 1.947095 & -1.481851 & -1.657089 \\
\hline 1.384100 & -1.840314 & -3.321452 \\
\hline 3.011404 & -2.356707 & -2.787130 \\
\hline-4.741598 & 2.331599 & 3.162652 \\
\hline-4.960696 & -2.197939 & -3.150209 \\
\hline-4.653257 & 1.944407 & 4.538621 \\
\hline-5.548305 & 1.397157 & 4.859675 \\
\hline-4.578833 & 2.877829 & 5.099258 \\
\hline-3.761091 & 1.332567 & 4.723369 \\
\hline-4.832009 & -1.820751 & -4.526027 \\
\hline-5.671880 & -1.193661 & -4.850264 \\
\hline-4.841218 & -2.757170 & -5.086438 \\
\hline-3.886766 & -1.293108 & -4.706604 \\
\hline-4.863244 & -3.118897 & -0.520601 \\
\hline-4.971888 & -3.678381 & -1.452752 \\
\hline-5.757947 & -3.329534 & 0.070381 \\
\hline-4.957810 & -2.022516 & 1.834477 \\
\hline 4.691417 & -0.098307 & -2.080294 \\
\hline 6.958339 & -0.113050 & -1.086899 \\
\hline 5.948683 & 3.969946 & 2.048303 \\
\hline
\end{tabular}


TS 1,5

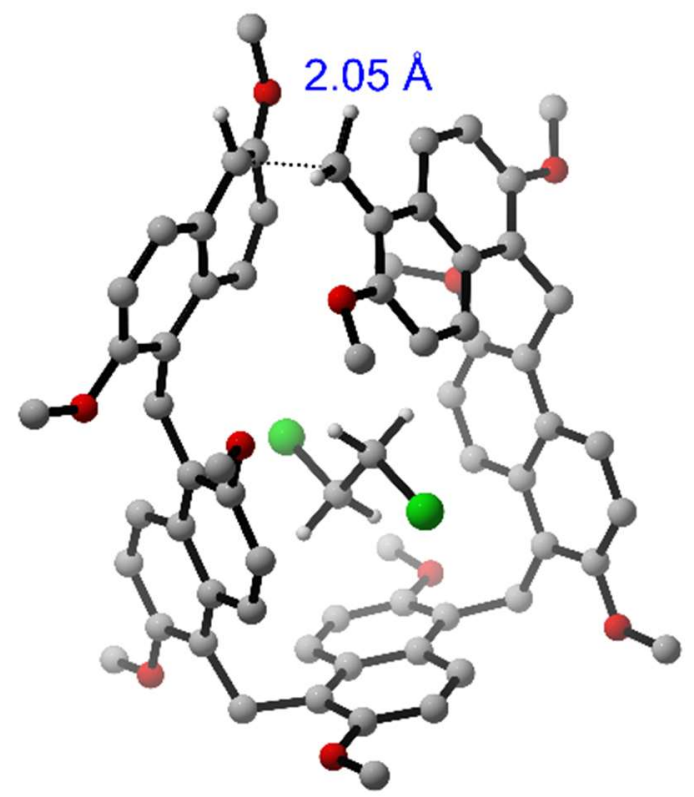

$$
E=0.0
$$

TS 1,4

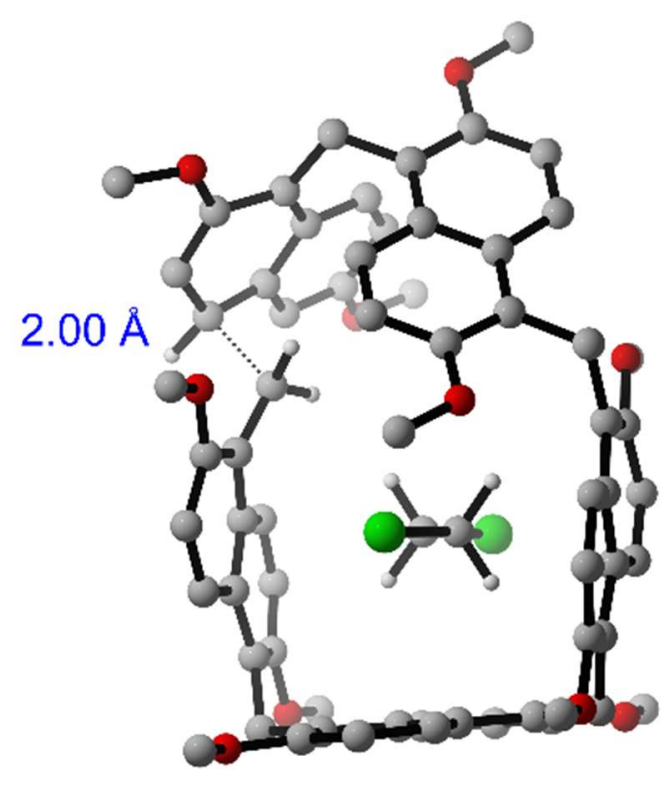

$E=+4.3$

Figure S78: The most stable transition states for the macrocyclization step leading to 1,5 and 1,4 products. Noncritical hydrogen atoms have been omitted for clarity. Relative energy is expressed in $\mathrm{kcal} / \mathrm{mol}$, The forming bond distances $(\AA)$ are highlighted in blue. 


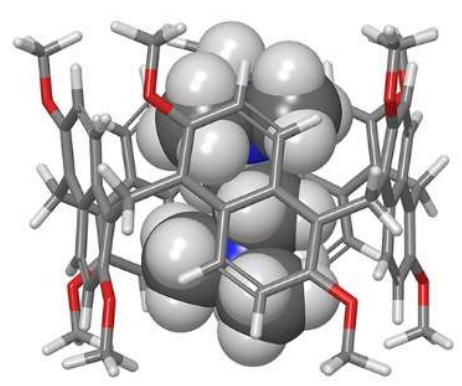

a)

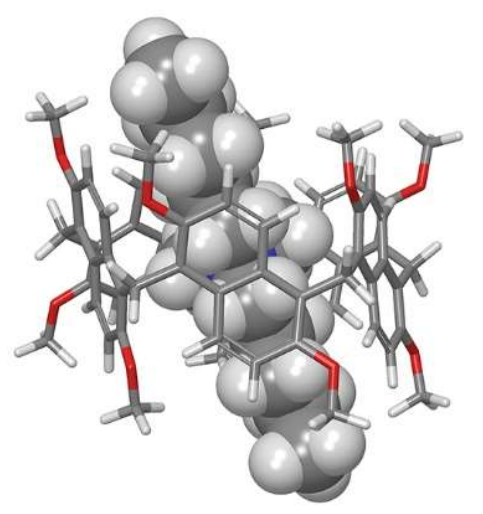

d)

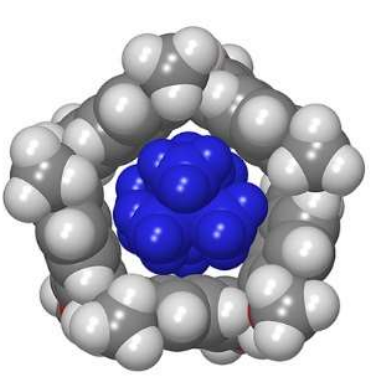

b)

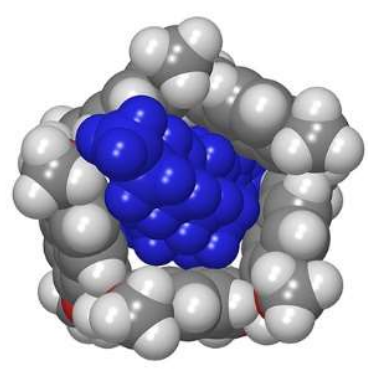

e)

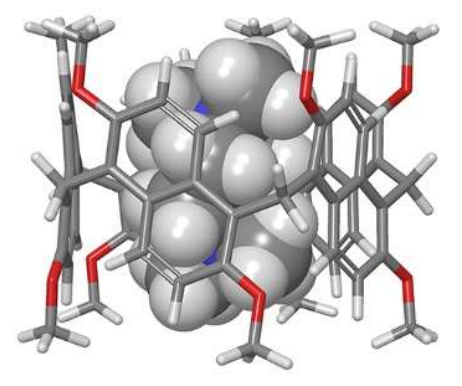

c)

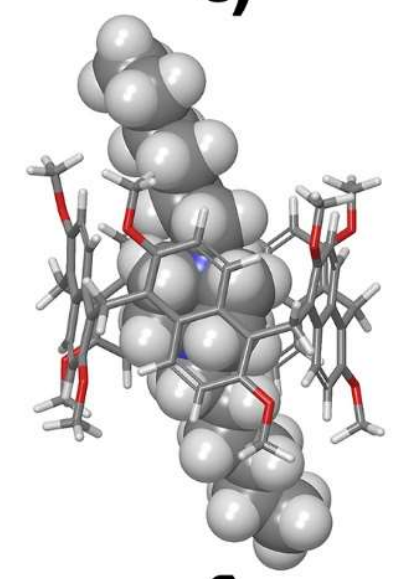

f)

Figure S79. DFT-optimized structures (B97D3/SVP/SVPFIT) of the: a and b) different views of the $\mathbf{1 0}^{2+} \subset \mathbf{1}$ endo-complex, stabilized by $\mathrm{C}-\mathrm{H} \cdots \pi$ interactions $(\mathrm{C}-\mathrm{H} \cdots$ $\pi^{\text {centroids }}$ distance of $2.80 \AA$ A. c) $\mathbf{9}^{2+} \subset \mathbf{1}$ endo-complex. d) $\mathbf{8}^{+} \subset \mathbf{1}$ pseudorotaxane. The $N^{+}$-methyl groups of $\mathbf{8}^{+}$are involved in $\mathrm{C}-\mathrm{H} \cdots \pi$ interactions $\left(\mathrm{C}-\mathrm{H} \cdots \pi^{\text {centroids }}\right.$ distance of $2.45 \AA$ and $\mathrm{C}-\mathrm{H} \cdots \pi^{\text {centroids }}$ angle of $\left.160^{\circ}\right)$. e, f) Different views of the $4^{2+} \subset \mathbf{1}$ pseudorotaxane. $\mathrm{C}-\mathrm{H} \cdots \pi$ interactions were detected between the ethylene groups ${ }^{+} \mathrm{NCH}_{2} \mathrm{CH}_{2} \mathrm{~N}^{+}$and the aromatic walls of $\mathbf{1}\left(\mathrm{C}-\mathrm{H} \cdots \pi^{\text {centroids }}\right.$ distance of $\left.2.72 \AA\right)$. 


\section{References}

[1] Williams, D. B. G.; Lawton, M. Drying of Organic Solvents: Quantitative Evaluation of the Efficiency of Several Desiccants. J. Org. Chem. 2010, 75, 8351-8354.

[2] Fulmer, G. R.; Miller, A. J. M.; Sherden, N. H.; Gottlieb, H. E.; Nudelman, A.; Stoltz, B.M.; Bercaw, J.E.; Goldberg, K.I. NMR Chemical Shifts of Trace Impurities: Common Laboratory Solvents, Organics, and Gases in Deuterated Solvents Relevant to the Organometallic Chemist. Organometallics 2010, 29, 2176-2179.

[3] Gaeta, C.; Troisi, F.; Neri, P. endo-Cavity Complexation and Through-the-Annulus Threading of Large Calixarenes Induced by Very Loose Alkylammonium Ion Pairs. Org. Lett. 2010, 12, 20922095.

[4] Bakić, M. T.; Iuliano, V.; Talotta, C.; Geremia, S.; Hickey, N.; Spinella, A.; De Rosa, M.; Soriente, A.; Gaeta, C.; Neri, P. Threading of Conformationally Stable Calix[6]arene Wheels Substituted at the Methylene Bridges. J. Org. Chem. 2019, 84, 11922-11927.

[5] Kabsch, W. XDS. Acta Crystallogr. 2010, D66, 125-132.

[6] Kabsch, W. Integration, Scaling, Space-Group Assignment and Post-Refinement. Acta Crystallogr. 2010, D66, 133-144.

[7] Sheldrick, G. M. SHELXT - Integrated Space-Group and Crystal-Structure Determination. Acta Crystallogr. 2015, A71, 3-8.

[8] Sheldrick, G. M. A Short History of SHELX. Acta Crystallogr. 2008, A64, 112-122.

[9] Farrugia, L.J. WinGX and ORTEP for Windows: an Update. J. Appl. Cryst. 2012, 45, 849-854. 